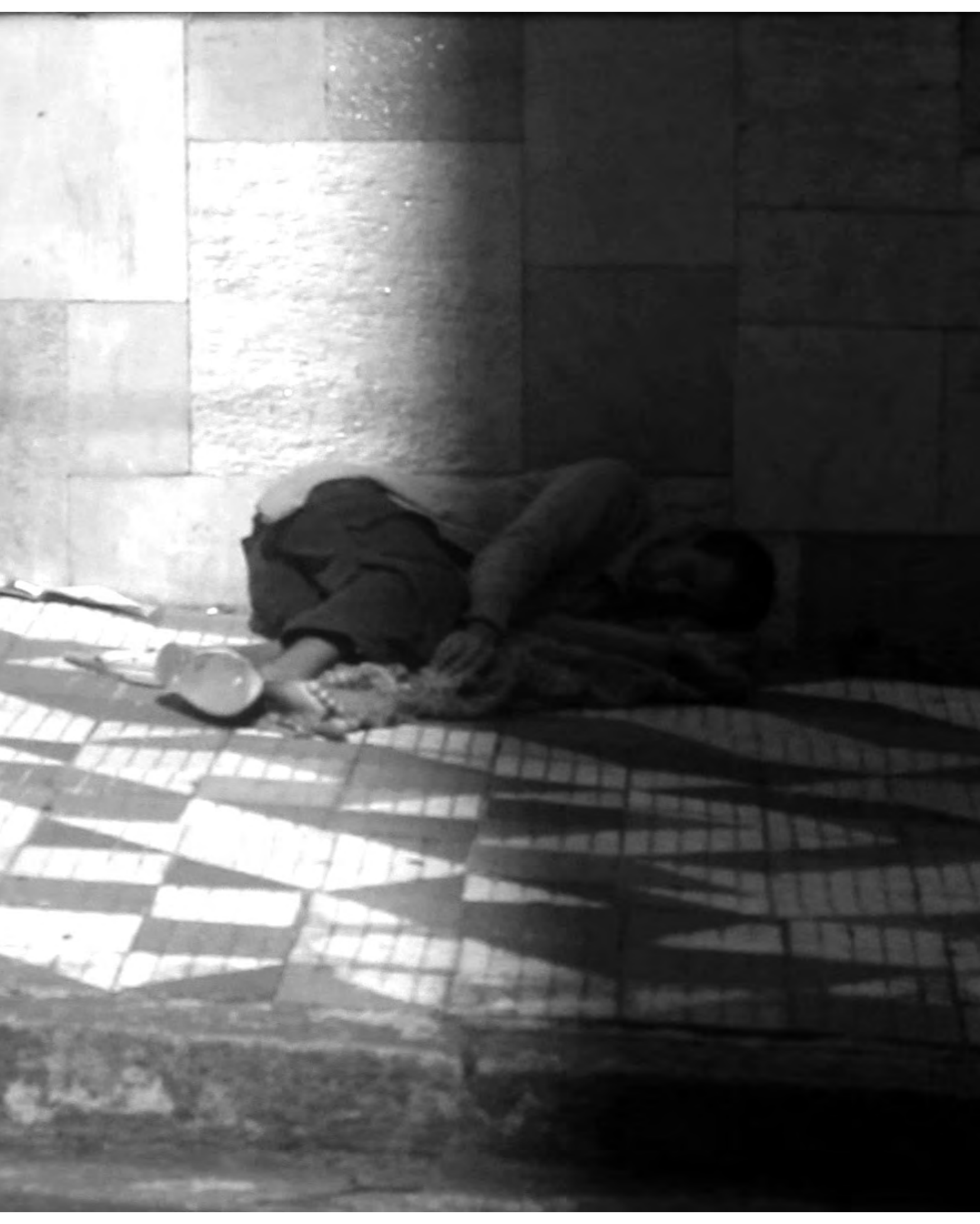




\section{Os deslocamentos territoriais dos adultos moradores de rua nos Bairros Sé e República}

Dissertação apresentada à Faculdade de Arquitetura e Urbanismo da Universidade de São Paulo para obtenção do título de Mestre em Arquitetura e Urbanismo

Área de Concentração:

História e Fundamentos da Arquitetura e do Urbanismo

Linha de pesquisa:

Teorias e História do Urbanismo, da Urbanização e do Projeto Urbano

Orientadora: Profa. Dra. Maria Ruth Amaral de Sampaio 


\begin{abstract}
AUTORIZO A REPRODUÇÃO E DIVULGAÇÃO TOTAL OU PARCIAL DESTE TRABALHO, POR QUALQUER MEIO CONVENCIONAL OU ELETRÔNICO, PARA FINS DE ESTUDO E PESQUISA, DESDE QUE CITADA A FONTE.
\end{abstract}

ASSINATURA

michelle.mendez@me.com e mendez.esquinca@gmail.com

\title{
Esquinca, Michelle Marie Méndez
}

E82d Os deslocamentos territoriais dos adultos moradores de rua nos bairros Sé e República/ Michelle Marie Méndez Esquinca. São Paulo, 2013. 254 p. : il.

Dissertação (Mestrado - Área de Concentração: História e Fundamentos da Arquitetura e do Urbanismo) - FAUUSP.

Orientadora: Maria Ruth Amaral de Sampaio

1. Morador de rua 2. Espaço público 3. Renovação urbana 4. Assistência social İ. Título

CDU 304(1-21) 
ESQUINCA, M. M. M. Os deslocamentos territoriais dos adultos moradores de rua nos bairros Sé e República. 2013. 254 f. Dissertação apresentada à Faculdade de Arquitetura e do Urbanismo, Universidade de São Paulo para obtenção do título de Mestre em Arquitetura e Urbanismo.

Aprobado em:

Banca Examinadora

Prof. Dr. .................... Instituição:

Julgamento: $\ldots \ldots \ldots \ldots \ldots \ldots \ldots$ Assinatura:

Prof. Dr. $\quad \ldots \ldots \ldots \ldots \ldots \ldots \ldots \ldots$ Instituição:

Julgamento: $\ldots \ldots \ldots \ldots \ldots \ldots \ldots$ Assinatura:

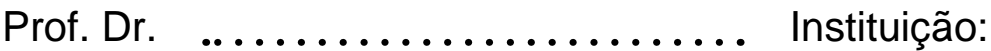

Julgamento: $\ldots \ldots \ldots \ldots \ldots \ldots \ldots$ Assinatura: 


\section{A GRADECIMIENTOS}

À Profa. Dra. Maria Ruth Amaral de Sampaio, que nos meses de convivência contribuiu para meu crescimento intelectual e pessoal.

À Lic. Anabella Acevedo, que apresentou o Brasil como uma das melhores opções para minha formação como profissional na área de urbanismo.

À Fundação Ford, que por dez anos contribuiu para a formação de profissionais ao redor do mundo, sem cujo apoio eu não teria tido a bolsa de mestrado e o apoio financeiro para a realização da presente pesquisa.

À equipe de trabalho do Centro Integrado de Estudos e Programas de Desenvolvimento Sustentável (CIEDS), especialmente ao Dr. Odilon Castro e à Lic. Renata Batisteli, que apoiaram o trabalho de campo que contribuiu em grande parte no desenvolvimento da análise da presente pesquisa.

À Profa. Karin Zerwes Kansog, que acompanhou o desenvolvimento da presente pesquisa até o final.

Ao Mathias Patrick Gruber, que compartilhou a fotografia que constitui a capa interna do presente trabalho, consiguiu-se com ela resumir os resultados do presente trabalho. 
Quem sabe quando aprendermos a conversar com aquele que passa na rua, oprimido e desiludido com a situação social e a penúria em que se encontra, nós mesmos não nos transformaremos num ser humano melhor?

Santa Teresa de Calcutá 


\section{RESUMO}

ESQUINCA, M. M. M. Os deslocamentos territoriais dos adultos moradores de rua nos bairros Sé e República. 2013. 196 f. Dissertação (Mestrado) - Faculdade de Arquitetura e Urbanismo, Universidade de São Paulo, 2013.

É fácil perceber no centro da cidade de São Paulo a população em situação de rua; embora sua presença seja notória, a natureza do fenômeno de rua é para muitos desconhecida. Ao observá-lo, dissipam-se os preconceitos e emergem os aspectos complexos da vida de rua, sendo um deles o deslocamento. Embora que eles se deslocam, as pessoas em situação de rua continuam no mesmo lugar pois se mantem nos espaços públicos da cidade e na mesma situação precária de vida. Na situação de rua existem vários tipos de deslocamentos, porém o presente estudo se foca nos deslocamentos territoriais. Grande parte da população de rua se desloca todos os dias na cidade de São Paulo por diferentes motivos; sejam deslocamentos territoriais curtos, sejam longos, constituem o interesse da presente pesquisa. A concatenação das diversas razões que motivam os deslocamentos territoriais dos moradores de rua e das ações das autoridades locais (de renovação ou de assistência social) torna os deslocamentos desenvolvidos na área central ações muito mais complexas. Tanto a renovação urbana da área central, quanto a assistência social especializada para o atendimento à população em situação de rua, parecem à primeira vista ações contraditórias. Por um lado, parece que a renovação urbana provoca que os moradores de rua fujam dos espaços públicos em que se desenvolvem os projetos urbanos, procurando espaços deteriorados do centro da cidade; por outro lado, a 
assistência social adquire ano a ano mais relevância na área central, provocando que muitos moradores de rua de outras áreas da cidade procurem acolhimento nos centros de assistência especializados que se localizam nessa área. Portanto, a pesquisa apresenta essas duas ações como polos que afastam e atraem os moradores de rua no centro da cidade. Desenvolve-se uma análise das ações das autoridades locais e dos dados dos censos dos moradores de rua a fim de entender os deslocamentos territoriais e seu impacto nos bairros Sé e República. Por constituir um fenômeno urbano cuja natureza flutuante parece adaptar-se ao contexto imediato, o presente estudo o aborda a partir de uma ótica urbana, de uma perspectiva ampla, com a qual se pretende esclarecer o agir desses atores na área central da cidade de São Paulo.

Palavras-chave: Morador de rua, Espaço público, Renovação urbana, Assistência social. 


\section{A B S TR A C T}

ESQUINCA, M. M. M. The territorial movements of homeless adults within the districts of Sé e República. 2013196 pgs. Thesis (Master's degree) - Faculty of Architecture and Urbanism, University of São Paulo, 2013.

It is easy to notice the population homeless people in the center of the city of São Paulo, though they have a notorious presence, the nature of the street phenomena is ignored by many. At a closer glance the prejudice dissipates and the complex aspects of the street life emerge, movement being one of them. Although they are always on the move, people in the street situation continue to be in the same place, for they remain in the same public spaces of the city and in the same precarious state of life. Within the context of the street life there are several kinds of movements, that is why this study focuses on the ones developed within the territory they occupy. Every day a great part of the street population moves within the city of São Paulo for different reasons, being either short or long, territorial movements constitute the main topic of this research. Once concatenated the reasons that motivate the territorial movements of the people that live in the streets and the actions of the local authorities (being that of renewal or welfare), the movements in the central area of the city turn into much more complex actions. Both the urban renewal of the central area and the welfare specialized on the treatment of the street population at first seem contradictory actions. On one side, it seems that the urban renewal causes the retreat of the homeless from the public spaces where the projects are developed, seeking other deteriorated spaces within the center of the city; on the other side, year by year welfare acquires more relevance 
in the central area, encouraging people in the street situation on other areas of the city to seek shelter in the specialized treatment centers on the central region. Therefore this academic research presents those two actions as poles that attract and withdraw the homeless in the central region of the city. It was developed an analysis of the actions of the local authorities and the censuses of the street population, that was done in order understand the territorial movements and their impact on the districts of the central region, Sé and Republic. Because it is an urban phenomena, whose wavy nature seems to adapt to the immediate context, this study has an urban approach, a broad perspective, with which seeks to enlighten the action of those players within the central region of the city of São Paulo.

Key words: Homless, Public space, Urban renewal, Welfare. 


\section{LISTA DE MAPAS}

Mapa 1 - Expansão da Área Urbanizada 11

Mapa 2 - Inclusão e exclusão 14

Mapa 3 - Inclusão e exclusão 14

Mapa 4 - Área de abrangência do PROCENTRO 15

Mapa 5 - Equipamento de assistência social 15

Mapa 6 - Limites administrativos da área central .90

Mapa 7 - Distritos Sé e República 92

Mapa 8 - Distritos Sé e República e seus territórios menores .92

Mapa 9 - Distrito Sé e seus territórios menores .93

Mapa 10 - Perímetro 1 .94

Mapa 11 - Perímetro 2 .96

Mapa 12 - Perímetro 3 .98

Mapa 13 - Perímetro 4 100

Mapa 14 - Perímetro 5 101

Mapa 15 - Perímetro 6 102

Mapa 16 - Perímetro 7 103

Mapa 17 - Distrito República e seus territórios menores 104

Mapa 18 - Perímetro 8 .106

Mapa 19 - Perímetro 9 108

Mapa 20 - Perímetro 10 .110

Mapa 21 - Subprefeituras da Cidade de São Paulo 144 


\section{LISTA DE GRÁFICOS}

Gráfico 1 - Censos dos moradores de rua da Cidade de São Paulo (1991-2009) .. 28

Gráfico 2 - Contagem dos moradores de rua na cidade de São Paulo (2000-2009) 82

Gráfico 3 - Porcentagem do crescimento da população de rua na cidade .83

Gráfico 4 - Moradores de rua no centro da cidade de São Paulo 2000 - 2009 86

Gráfico 5 - Os distritos da Subprefeitura Sé 91

Gráfico 6 - Assistência Social na Cidade de São Paulo 158

Gráfico 7 - Distribuição dos Centros de Assistência Social na Subprefeitura Sé .158

Gráfico 8 - Modalidade de atendimento à população de rua 160

Gráfico 9 - Modalidade de atendimento à população de rua 161

Gráfico 11 - População da Subprefeitura Sé 1950-2010 179

Gráfico 12 - População do bairro Bom Retiro 1950-2010 182

Gráfico 13 - População do bairro Sé 1950-2010 182

Gráfico 14- População do bairro Cambuci 1950-2010 183

Gráfico 15 - Moradores de rua na cidade de São Paulo e na Subprefeitura Sé ..184

Gráfico 16 - Moradores de rua acolhidos na cidade e na Subprefeitura Sé 187

Gráfico 17 - Moradores de rua não acolhidos na cidade e na Subprefeitura Sé ..188

Gráfico 18 - Moradores de rua não acolhidos e acolhidos no Centro 189

Gráfico 19 - Moradores de rua não acolhidos e acolhidos no Centro 190

Gráfico 20 - Total de moradores de rua no Centro 1991-2011 191

Gráfico 21 - Moradores de rua não acolhidos e acolhidos 1991-2011 .191

Gráfico 22 - Moradores de rua não acolhidos no Centro 1991-2011 193 
Gráfico 23 - Moradores de rua não acolhidos e acolhidos no Centro 1991-2011 ..194

Gráfico 24 - Total de Moradores de rua nos bairros da Subprefeitura Sé ............196

Gráfico 25 - Moradores de rua acolhidos na Subprefeitura Se ..........................197

Gráfico 26 - Moradores de rua não acolhidos na cidade e no Centro ..................197

Gráfico 27 - Moradores de rua não acolhidos e acolhidos no Centro 2000 ..........200

Gráfico 28 - Moradores de rua não acolhidos e acolhidos no Centro 2009 .........200

Gráfico 29 - Moradores de rua não acolhidos e acolhidos no Centro 2012 .........201

Gráfico 30 - Moradores de rua não acolhidos e acolhidos no Bairro Cambuci ......203

Gráfico 31 - Moradores de rua não acolhidos e acolhidos no Bairro Cambuci ......203

Gráfico 32 - Moradores de rua não acolhidos e acolhidos no Bairro República ....204

Gráfico 33 - Moradores de rua não acolhidos e acolhidos no Bairro Sé ................205

Gráfico 34 - Moradores de rua não acolhidos e acolhidos no Bairro Bela Vista ....206

Gráfico 35 - Moradores de rua não acolhidos e acolhidos no Bairro Liberdade ....207

Gráfico 36 - Moradores de rua não acolhidos e acolhidos no Bom Retiro .............207

Gráfico 37 - Moradores de rua não acolhidos e acolhidos no Bairro Santa Cecília 208

Gráfico 38 - Relação da população geral - população de rua 2000 / 2009 210 


\section{LISTA DE TABELAS}

Tabela 0 - Denominações atribuídas aos moradores de rua .36

Tabela 1 - Prefeitos da Cidade de São Paulo 130

Tabela 2 - Delimitações do território da Cidade de São Paulo 141

Tabela 3 - Ações da Prefeitura no Centro da Cidade de São Paulo 147

Tabela 4 - Censos de moradores de rua na cidade de São Paulo 190 


\section{LISTA DE SIGLAS}

AR Administrações Regionais

AVC $\quad$ Associação Viva o Centro

BID Banco Interamericano de Desenvolvimento

CAPE Central de Atendimento Permanente e de Emergência

CAS Coordenadoria de Assistência Social

CASA Centro de Atendimento Socioeducativo ao Adolescente

CEDECA Centros de Defesa dos Direitos da Criança e do Adolescente

CETREM Centro de Terapia e Reabilitação Integrada Municipal

CIEDS Centro Integrado de Estudos e Programas de Desenvolvimento Sustentável

CRAS Centros de Referência de Assistência Social

CREAS Centros de Referência Especializados de Assistência Social

COGEP Coordenadoria de Gestão de Pessoas

DSS Divisão de Serviço Social

EMURB Empresa Municipal de Urbanização

FEBEM Fundação Estadual para o Bem Estar do Menor

GCM Guarda Civil Metropolitana

IBGE Instituto Brasileiro de Geografia e Estatística

LOM Lei Orgânica do Município

LOAS Lei Orgânica da Assistência Social

ONG Organizações Não Governamentais

PAEFI Proteção e Atendimento Especializado a Famílias e Indivíduos 


\begin{tabular}{|c|c|}
\hline PDE & Plano Diretor Estratégico \\
\hline PDDI & Plano Diretor de Desenvolvimento Integrado \\
\hline PIAC & Plano Integrado da Área Central \\
\hline PMDU & Plano Metropolitano de Desenvolvimento Urbano \\
\hline PRE & Plano Regional Estratégico \\
\hline PNAS & Política Nacional de Assistência Social \\
\hline PNMR & Pesquisa Nacional de Moradores de Rua \\
\hline PROCENTRO & Programa de Reabilitação da Área Central do Município de São Paulo \\
\hline PUB & Plano Urbanístico Básico \\
\hline SAGMACS & $\begin{array}{l}\text { Sociedade para Análise Gráfica de Mecanográfica Aplicadas aos } \\
\text { Complexos Sociais }\end{array}$ \\
\hline SEBES & Secretaria Municipal de Bem-Estar Social \\
\hline SEHAB & Secretaria de Habitação \\
\hline SMADS & Secretaria Municipal de Assistência e Desenvolvimento Social \\
\hline SPAM & Sistema de Planejamento e Administração Metropolitano \\
\hline SUAS & Sistema Único de Assistência Social \\
\hline USP & Universidade de São Paulo \\
\hline ZEIS & Zonas Especiais de Interesse Social \\
\hline
\end{tabular}




\section{S U M A R IO}

Introdução

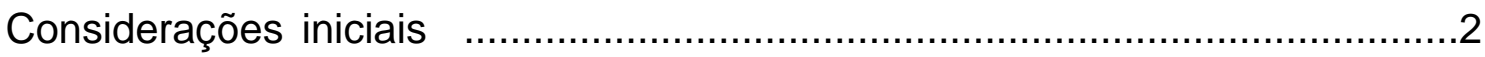

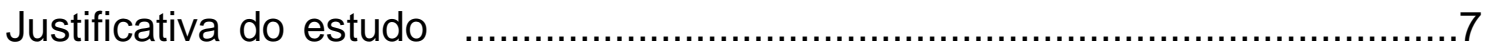

Objeto do estudo

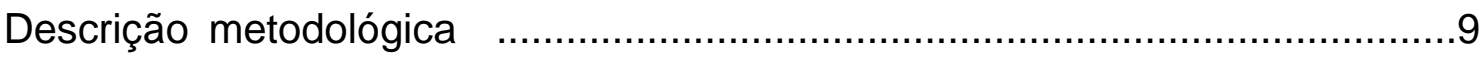

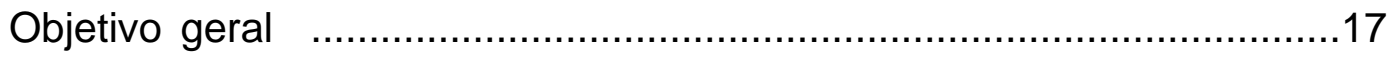

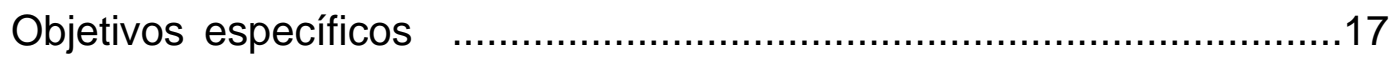

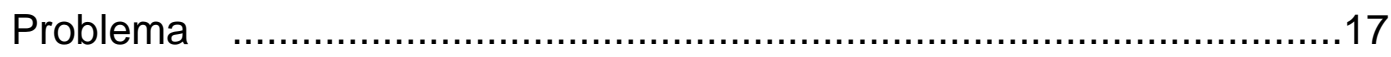

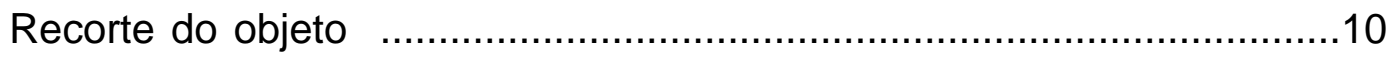

Etapas da pesquisa

1. O fenômeno de rua na cidade de São Paulo ………....................................21

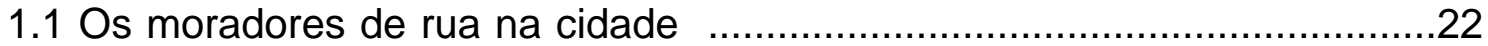

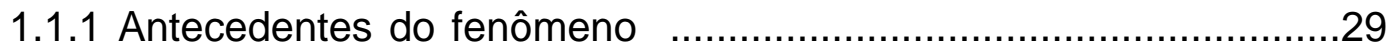

1.1.2 O conceito do morador de rua no século XX ..............................31

1.1.2.1 Três perfis predominantes dentro da população de rua ... 37

1.1.2.2 As condições dos moradores de rua ................................44

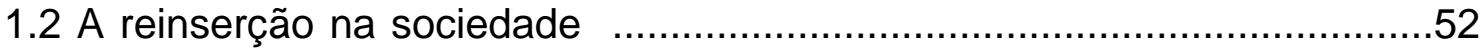

2. O Agir dos moradores de rua no Centro da cidade ........................................59

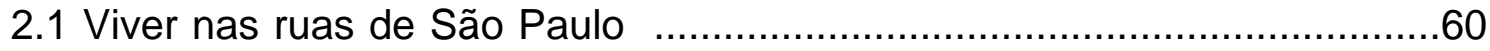

2.1.1 As estratégias de subsistência e as funções urbanas .................71

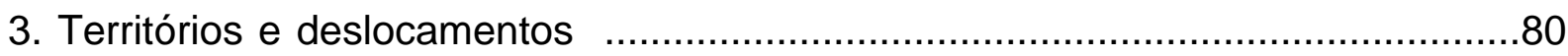

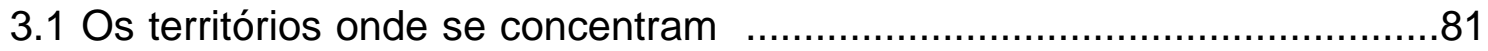




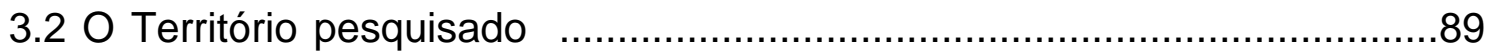

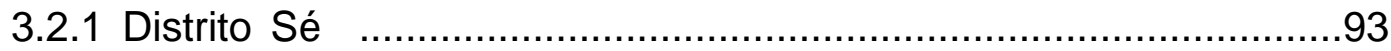

3.2.2 Distrito República ............................................................104

3.3 Os deslocamentos dos moradores de rua ……...............................112

3.3.1 Deslocamentos territoriais ...................................................121

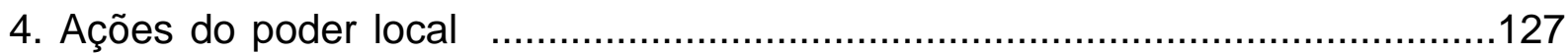

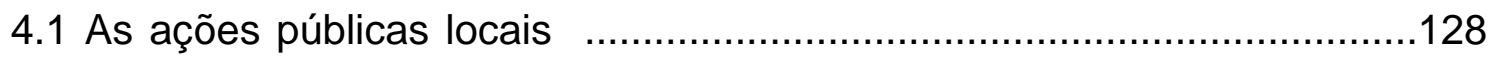

4.1.1 Inconsistência das políticas públicas relativas à área central ...128

4.1.2 Definição do território ........................................................137

4.1.3 Descentralização administrativa do território …………...........142

4.1.3.1 As ações de requalificação da Área Central ..................145

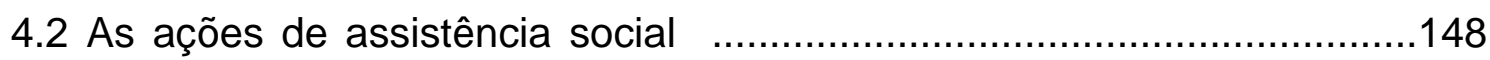

4.2.1 Os equipamentos para pessoas em situação de rua .................165

4.2.1.1 Equipamentos de pernoite ........................................168

4.2.1.2 Equipamentos de apoio para a vida na rua ...................174

4.2.1.3 Equipamento de apoio para a reinserção ......................176

5. Consequências das políticas públicas ………………………………....178

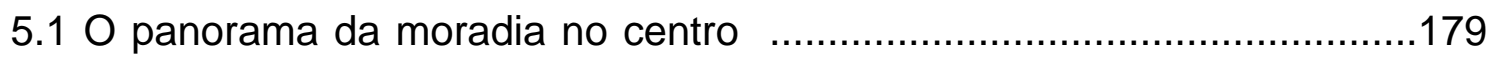

5.2 Moradores de rua no centro de São Paulo no 2002-2010 …................183

5.2.1 Moradores de rua acolhidos e não acolhidos ............................195

5.3 A relação população geral-população de rua ......................................209

Conclusões 


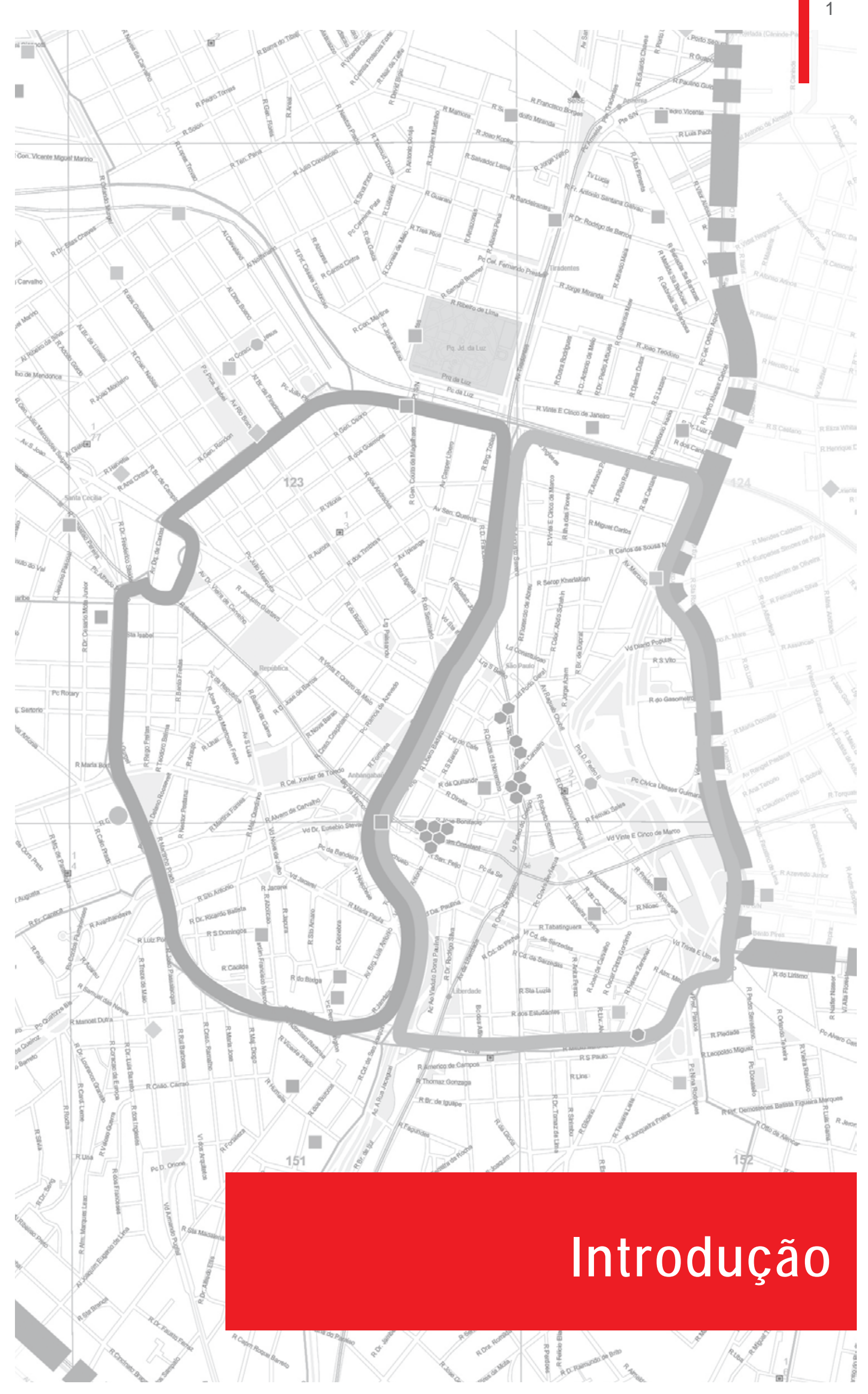




\section{CONSIDERAÇÕES INICIAIS}

O fenômeno de pessoas morando nas ruas das cidades não é novo, e desde seus primeiros registros o deslocamento se descreve como uma de suas características. $\mathrm{Na}$ Roma Antiga, registraram-se contingentes de pessoas que, por guerras ou mudanças políticas, se deslocaram de uma cidade a outra. Da mesma forma no período entre a Idade Média e a Era Industrial, milhares de pessoas se trasladaram, também, na procura de emprego e melhores condições de vida. Essas migrações desenvolviamse em condições de miséria extrema; portanto, ao chegar às cidades, as estratégias de sobrevivência eram a mendicância, o roubo e a prostituição.

Após a Era Industrial, a chegada do urbano às cidades produziu grandes mudanças em suas dinâmicas. As funções urbanas aumentaram, passando das primárias às secundárias, evoluindo até as terciárias, o que quer dizer que o homem já não só plantava ou coletava, mas processava o coletado e o apresentava à venda; estas últimas atividades passaram a se dar por meio da indústria e da prestação de serviços especializados. À medida que na cidade se desenvolvem funções mais complexas, seus atores mudam a fim de adaptar-se a elas; por isso os moradores de rua descritos nos primeiros textos de Sociologia dos primeiros decênios do século $X X$, de autores como Robert Ezra Parker, não são os mesmos que se encontram nas ruas hoje. Os moradores de rua mudaram seu agir a fim de adaptar-se às mudanças dos centros urbanos, eles desenvolvem uma forte pertença aos espaços ocupados, já que "no contexto urbano, as lutas de facções, de grupos, de classes, reforçam o sentimento de pertencer" (SMPSP, 2011, p. 60, 64, 117 / LEFEBVRE, 2011, p. 13). 
Após a crise econômica dos últimos três decênios do século XX na cidade de São Paulo, começou-se a observar o crescimento da população de rua. Esse fenômeno nunca antes se tinha apresentado nessa escala e não passou despercebido; logo as autoridades locais e os pesquisadores passaram a interessar-se pela população de rua da cidade. A partir de 1990, esses interesses começaram a se transformar em ações concretas, visto que se realiza o primeiro censo de moradores de rua desenvolvido pela Prefeitura da cidade. No ano de 1990, organizou-se um grupo de trabalho específico que começou a desenvolver as contagens no centro da cidade. $O$ início das contagens anuais mudou o conceito que orientava o trabalho, a metodologia, a sistematização e o órgão executor das ações do poder local relacionadas com a população de rua; como até então não se tinha informação concreta do fenômeno de rua, as poucas ações da prefeitura se baseavam em especulações devido à falta de dados (VIEIRA / BEZERRA / ROSA, 1992, p. 49).

Apesar das ações do poder local definirem inicialmente o conceito de "sem teto" para começar a abordar a problemática da população vulnerável, a abrangência dessas contagens era ampla: incluía a população em condições de habitação precária - os moradores de cortiços, favelas e população de rua. A Prefeitura de São Paulo decide mudar a estratégia na década seguinte, ao reduzir suas ações focadas num grupo específico: a população de rua. Hoje, como produto desses trabalhos e estudos, pode-se falar tanto em três perfis predominantes de moradores, quanto no fato de que esses indivíduos se acham em duas condições, crônica e temporária. Na cidade de São Paulo, os moradores de rua desenvolvem-se ao redor de uma dúzia de estratégias de sobrevivência, a maioria das quais se relacionam com as atividades desenvolvidas 
no centro da cidade. Foram os censos que apresentaram tanto o crescimento da população de rua em toda a cidade, quanto as particularidades de seus setores. Ao avaliar as dinâmicas do crescimento desse grupo no centro de São Paulo, apresentouse ora o crescimento da população de rua em uns bairros, ora diminuição em outros. Esse fato, junto à tendência geral de crescimento, indicou que existem deslocamentos de moradores de rua dentro da cidade. Ao se estudarem esses deslocamentos, surgem suas diferentes lógicas, pois nem todas as causas para trasladar-se de um lugar a outro são as mesmas, o caráter heterogêneo da população de rua faz com que se apresentem particularidades por questões de gênero ou das faixas etárias.

Os deslocamentos territoriais dos adultos em situação de rua constatados pela presente pesquisa estão vinculados com os dois eixos das ações locais na Área Central: a assistência social e a requalificação do centro da cidade. Ao estabelecer essas relações entre as ações locais e o agir do povo de rua, apresenta-se a ideia de que os deslocamentos deste, por envolverem uma lógica influenciada pelas ações públicas e privadas, podem vir a ser orientados pelo poder público.

\section{OBJETO DO ESTUDO}

O presente estudo pesquisa os deslocamentos territoriais dos adultos em situação de rua na cidade de São Paulo. Tem início com a procura dos antecedentes do fenômeno de rua dos últimos anos para se determinar o território e o período a ser focado neste trabalho. Nas sociedades capitalistas do século $X X$, as relações sociais que se processam a partir do eixo capital/trabalho produzem desigualdades sociais notáveis 
Essas desigualdades parecem crescer a partir da reestruturação produtiva, da reorientação do papel do Estado e da supervalorização do capital financeiro sobre o capital produtivo. O fenômeno da população em situação de rua é uma expressão das desigualdades sociais resultantes das relações sociais capitalistas. O desenvolvimento do urbano nas cidades do século $X X$ mudou o agir de muitos atores sociais, sendo um desses atores o povo de rua. Pode descrever-se o fenômeno de rua antes e após o desenvolvimento do urbano (SILVA: 2008, p. 219).

A partir das crises econômicas e das medidas dos setores público e privado nas décadas de 70 e 80, crescem o desemprego e o trabalho precário, elevando os índices de pobreza e consequentemente os níveis de vulnerabilidade de um grande setor da população. Já durante o decênio de 1980 se registra um contingente de pessoas que moram na rua, não só em São Paulo mas também em outros centros urbanos. O agravamento do desemprego representa uma pressão sobre as políticas públicas do estado de bem-estar social (welfare state); muitas das ações de assistência social foram deixadas por falta de recursos econômicos. Nos países menos desenvolvidos, as consequências da crise apresentam um quadro particular, pois se busca reduzir o tamanho do Estado por meio de subsídios: o Estado deixa de executar e decretar, delegando funções ao setor privado, com quem passa a ter que negociar. Esse processo gera novos atores sociais; primeiro: o novo pobre - produto de um sistema de proteção social falho num quadro agravado pela revolução tecnológica após a crise econômica mundial. Além dele, o novo miserável - nesse momento crítico de crise econômica e financeira, a população que já estava nos estratos mais baixos é despojada dos meios de produzir riqueza para uso próprio e é submetida a níveis extremos de degradação 
de vida. Foi uma reação em cadeia: uma porção da população de classe média baixa tornou-se os novos pobres, e os antigos pobres passaram a ser os novos miseráveis. Essa população em risco, os novos miseráveis, foi à rua por não ter outra opção de gerar riquezas (emprego) e portanto por não ter a possibilidade de partilhar da distribuição de seus frutos (consumo). Ao longo da história, essa população tem como locais de reunião os espaços públicos dos centros urbanos, onde existem possibilidades de sustento, já que neles se concentra a circulação de capital, havendo infraestrutura assistencial, além de arquitetura e geopolítica que apoiam seu sustento. Essa é a razão pela qual, hoje, muitos catalogam o fenômeno de rua como um fenômeno urbano. O caso dos moradores de rua de São Paulo apresenta particularidades, pois cada faixa etária da população de rua possui características diferentes, o que adiciona mais complexidade à pesquisa dessa população. Escolheu-se pesquisar especificamente os deslocamentos territoriais dos adultos em situação de rua, já que eles constituem a faixa etária com um maior número de casos de situação de rua, sejam acolhidos pelos centros de assistência social ou sejam não acolhidos, constituem a faixa etária da população de rua da qual se obtiveram mais dados empíricos e referencias bibliográficas

Registraram-se casos de mendicância na cidade desde o começo do século XX, mas nunca antes tanto quanto hoje, e esta é uma das razões que motivaram a presente pesquisa. Por constituir um fenômeno amplamente pesquisado existem muitos termos relacionados com essa população específica, tais como moradores de rua, povo de rua, população em situação de rua e outros. O presente estudo se serve desses termos para referir-se à população de rua em geral, mas o termo escolhido para o objeto do estudo é "adulto em situação de rua", a fim de fornecer a identidade das pessoas que 
por diversas circunstâncias se acham morando nas ruas da cidade de São Paulo.

\section{JUSTIFICATIVA DO ESTUDO}

A fim de entender o comportamento das pessoas em situação de rua no território delimitado, procedeu-se a desenvolver a analise dos censos dos moradores de rua. Observou-se que existem variações na quantidade de pessoas em situação de rua. A pesquisa iniciou-se com a analise das estatísticas impulsionadas dela Prefeitura da cidade (2000-2009), elas mostram um aumento de 57\% da população de rua na cidade de São Paulo, principalmente na subprefeitura Sé, onde se observa que houve um aumento de 71\% no mesmo período. O último censo (2011) assinala que o Centro da cidade alberga $55,3 \%$ da população em situação de rua. O padrão geral da cidade é o aumento do número dos moradores de rua, embora certas áreas da cidade apresentem dinâmicas particulares. Avaliar a informação dos censos é um exercício obrigatório; tal avaliação evidencia que, em cada setor da cidade, o comportamento dos moradores varia, desarticulando a ideia de um padrão único e geral da vida na rua (PMSP, 2011 p. 6).

Por meio da informação dos censos, hoje sabemos que a maioria das Subprefeituras apresenta um aumento desse fenômeno. Embora o crescimento global da população de rua no período de 2000 até 2011 tenha sido continuo, apresentaram-se variações nos padrões no comportamento dos adultos em situação de rua nos bairros da cidade. Mooca e Sé possuíam a maior concentração de moradores de rua até 2009 - ambas tendo um crescimento notório de $37 \%$ e $71 \%$ respectivamente - enquanto outras 
Subprefeituras como Cidade Ademar, M'Boi Mirim e Perus apresentam um decréscimo. Observa-se hoje um panorama geral em que a população de rua aumenta, havendo a tendência do deslocamento de parte da população de uma área a outra na cidade. Existem também casos como os das Subprefeituras de Capela do Socorro, Ermelino Matarazzo, Itaim Paulista e São Mateus, que, no período de 2000 a 2009, apresentaram níveis de crescimento de população de rua atípicos. Tal situação nessas áreas indica que se têm desenvolvido estratégias de sobrevivência relacionadas ao comércio para adaptar-se a esses contextos fora do centro. O fato de que zonas que não enfrentavam a problemática dos moradores de rua há duas décadas hoje apresentem um crescimento, em certos casos de mais de $100 \%$ da população, assinala que o fenômeno de rua continua estendendo-se na cidade e adaptando-se a novas circunstâncias.

Esse crescimento em áreas fora do Centro (por exemplo, na Capela do Socorro, a quantidade de 17 moradores de rua em 2000 passou para 201 em 2009) é um fato que propicia novas pesquisas nessas áreas, pois destaca a grande capacidade de adaptação da população de rua e a possibilidade de que esses crescimentos se devam aos deslocamentos territoriais pesquisados neste trabalho. Os indícios de deslocamentos territoriais, em maior ou menor escala entre Subprefeituras e distritos, mostram também uma lógica ligada às ações públicas e privadas. Por exemplo, os eventos na Área Central que se relacionam à requalificação do centro histórico e à assistência social estão diretamente ligados aos deslocamentos de moradores de rua em relação a esse local. Temos aí um panorama complexo, pois existem ações que puxam e empurram o deslocamento dos moradores de rua nesse território, no período 
de 2001 a 2010. Essas ações contraditórias, externas à população de rua, são as vezes simultâneas: o centro possui muitos elementos que os atraem e paralelamente ações que os afastam. As pesquisas realizadas na Faculdade de Arquitetura e Urbanismo da Universidade de São Paulo até hoje focaram as dificuldades enfrentadas pelos moradores de rua em relação a sua situação de moradia, mas nunca se abordou o tema dos seus deslocamentos, mesmo que sejam uma parte integral de seu agir. Esse fato motivou a presente pesquisa, pois se reconhece o relacionamento deste assunto com os temas de mobilidade e funções urbanas. Emerge a necessidade de um estudo urbano focado nos bairros, como Sé e República, no intuito de conhecer a lógica dos deslocamentos do povo de rua, assim como a de integrar os resultados desses estudos às políticas públicas e privadas referentes a essa população. Pois, se existe uma lógica em seus deslocamentos, isso implica que eles podem ser reorientados, sendo um fato a ser considerado em possíveis programas de reinserção social para aqueles que se deslocam nas ruas da cidade de São Paulo.

\section{DESCRIÇÃO METODOLÓGICA}

A fim de realizar a análise para se compreender a lógica dos deslocamentos dos moradores de rua, procurou-se a abordagem metodológica crítico-dialética, por reconhecer-se o desenvolvimento do mundo como um processo em constante mudança, resultado da interação de forças opostas. Tem seu ponto de partida nos fatos empíricos, buscando superar as primeiras impressões e as representações fenomenais, e chegar ao seu âmago. A metodologia faz uso de técnicas bibliográficas 
e históricas, com pesquisas de textos, documentos, registros e dados empíricos, priorizando a análise do discurso. Concebe a realidade sob as categorias de totalidade, contradição, mediação, ideologia e práxis - conceitos básicos, que refletem os aspectos essenciais, propriedades e relações dos fenômenos e objetos. Constitui um enfoque não convencional, próprio das humanidades. Dita abordagem metodológica é apropriada para a pesquisa referente ao fenômeno de rua, especificamente pelo caráter heterogêneo da população em situação de rua.

\section{RECORTE DO OBJETO}

Segundo a metodologia implementada nos censos dos moradores de rua, essa população se distribui em quatro faixas etárias: crianças, adolescentes, adultos e idosos. O censo de 2011 assinala que 94\% do total da população de rua está constituída por pessoas adultas, o que os assinala como o grupo etário maioritário e predominante. Por isso o presente estudo foca tanto o marco teórico, quanto a analise nessa faixa etária. Na procura do setor que tem como característica significativa a presença dos moradores de rua na Cidade de São Paulo, as observações empíricas assinalaram a Área Central. Nesse setor da cidade, "existem muitas áreas em processo de degradação urbana" que propiciam sua apropriação por moradores de rua, vendedores informais e infratores. Por conseguinte, o estudo se deu nos bairros com uma grande concentração de população de rua. (SEMPLA, 2008, p. 50).

Assim como outros centros históricos da América Latina, São Paulo foi fundada a partir da delimitação da cidade clássica, o perímetro estabelecido 
na época colonial, com base nas diretrizes urbanísticas de Portugal. O centro da cidade está imerso em um tecido que continua seu processo de expansão urbana; dentro de seus limites, localizam-se os edifícios mais representativos da cidade, pontos turísticos de per si. Esse processo de expansão além da cidade clássica, tecido demarcadoem 1554 (vide Mapa 1), produz a deterioração do centro histórico de São Paulo (BORJA, 2007, p. 33).
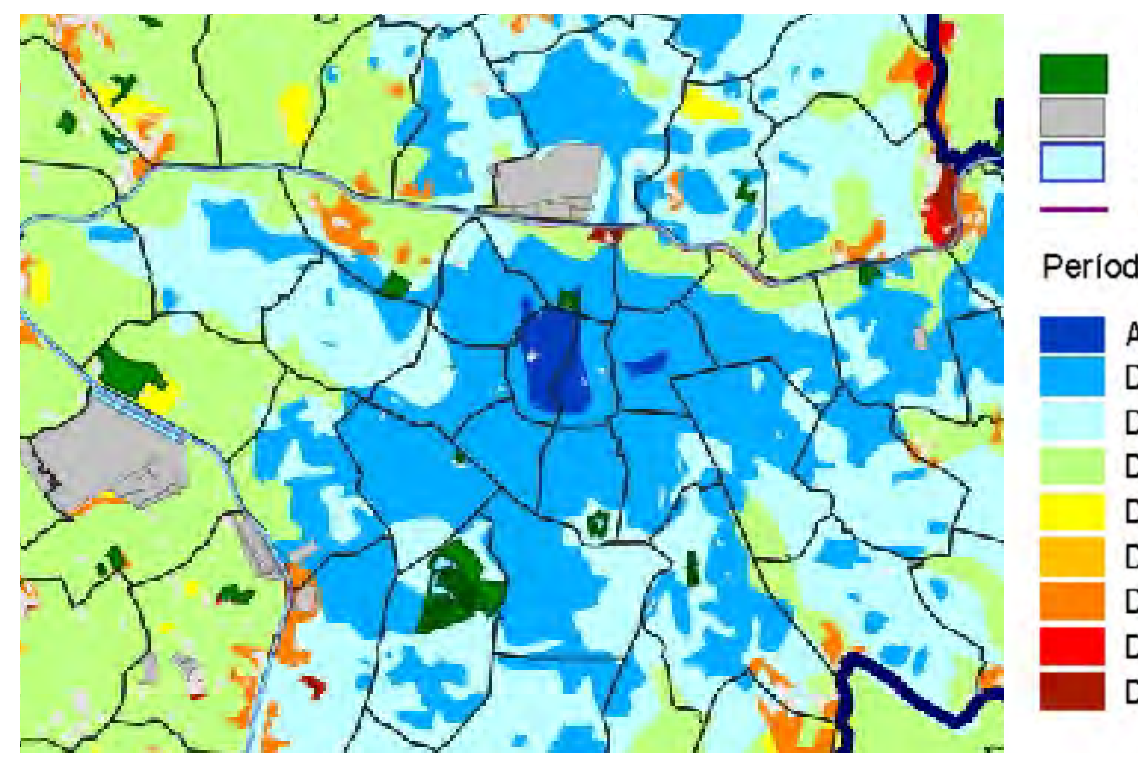

Parques no Munivípio de São Paulo Referências Urbanas Corpos d’Água

Limite de Proleção Mananciais

Períodos de Expansão

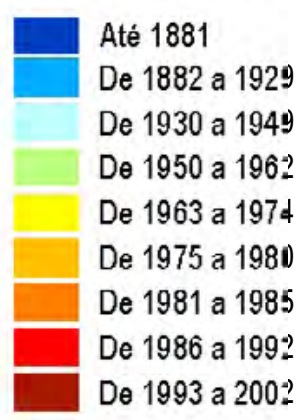

\section{Mapa 1 - Expansão da Área Urbanizada}

Com o desenvolvimento do urbano após o início da Era Industrial, apresentou-se um notável crescimento da populaçãoe surgiram novas funções, espaçose atores namaioria de centros urbanos de América Latina. Nesse momento nas cidades desenvolve-se um processo composto por dois aspectos: industrialização e urbanização, crescimento e desenvolvimento, produção econômica e vida social (LEFEBVRE, 2011, p. 16).

Na história recente, "o período de 1937 a 1945 apresentou uma expansão e diversificação do processo de industrialização", tendo como consequência 
mudanças nos centros históricos e adaptação de alguns atores urbanos a essas transformações. Nos 50 anos seguintes, a cidade de São Paulo passou por grandes mudanças; nesse período, os moradores de rua surgiram como um novo ator urbano nos espaços públicos e abertos (RODRIGUES:,2008, p. 2-3).

É percebido de maneira imediata que os moradores de rua se concentram no centro da cidade. As autoridades locais na década de 1990, orientadas pelas observações empíricas, focaram seus esforços em contagens que se iniciaram na Área Central. Uma década após as primeiras apurações, o Mapa da Inclusão e Exclusão Social (2002) mostra a concentração da população da rua na área central da cidade, principalmente nos distritos Sé, República, Brás, Liberdade e Mooca. O agrupamento do povo de rua nos distritos da Área Central da cidade não é por acaso: o fato de esses territórios apresentarem concentração de atividades de comércio e de serviços facilita o desenvolvimento das estratégias de sobrevivência na rua. O total da população de rua em 2009 era de 13.666 pessoas; nesse ano, 5.798 delas moravam no território da Subprefeitura Sé, o que representa $42 \%$ do total (vide Mapa 2).

Paralelamente aos esforços de diagnosticar as problemáticas sociais da cidade, a Prefeitura inicia o processo de descentralização. Na procura por administrar eficientemente o território em 2002, a cidade de São Paulo dividiu-se em 31 subprefeituras. A Área Central da cidade é constituída pela Subprefeitura Sé, formada por oito distritos, dos quais Santa Cecília (23\%), Sé (23\%) e República $(30,5 \%)$ concentram três quartos do total da população de rua dessa subprefeitura (vide Mapa 3). Até hoje, os bairros Sé e República mantêm-se no imaginário coletivo como o " 
centro tradicional da cidade", mesmo que a cidade tenha desenvolvido reformas administrativas (SEMPLA, 2008, p. 3; SMDU/ DIPRO, 2009 / SEMPLA, 2008, p. 50).

Havendo uma administração específica para esse território, impulsionaram-se políticas destinadas à área; a partir delas, criou-se o Programa de Reabilitação da Área Central do Município de São Paulo (PROCENTRO). A área de abrangência do programa é formada por 10 bairros, entre os quais Sé e República (vide Mapa 4). O programa tem a finalidade de "promover o desenvolvimento social e econômico da região, dinamizando e criando condições de atração e suporte de atividades compatíveis com o centro metropolitano". As ações implementadas na área promovem "a reabilitação urbanística e ambiental da área, com inclusão social". Os esforços da prefeitura da cidade na assistência social são implementados pela Secretaria Municipal de Assistência e Desenvolvimento Social (SMADS) por meio da Coordenadoria de Assistência Social (CAS). Concentrando seus esforços dentro do perímetro da Subprefeitura Sé, em 2009 a Prefeitura distribuiu $\mathrm{R} \$ 2.287 .322,25$ nessa área, o que equivale a $10 \%$ do seu orçamento (vide Mapa 5). Estima-se que o investimento mensal do setor público e privado por morador de rua fique entre $\mathrm{R} \$ 350,00$ e $\mathrm{R} \$ 500,00$. Encontra-se, na área, apoio para essa população alimentar-se, limpar-se, pernoitar, gerar renda e reabilitarse (PROCENTRO, 2011).

O presente estudo dedica-se aos distritos da área central, com concentração de população de rua, transformações nos espaços públicos e uma rede de assistência à população de rua considerável e consolidada; os bairros que reúnem essas características são Sé e República. No caso desses distritos nos últimos dez anos, as 
mudanças na administração do território, as transformações dos espaços públicos e a rede de equipamentos de assistência social, públicos e privados, dirigidos a essa população, parecem relacionar-se com os deslocamentos do povo de rua (SEMPLA, 2008, p. 50).

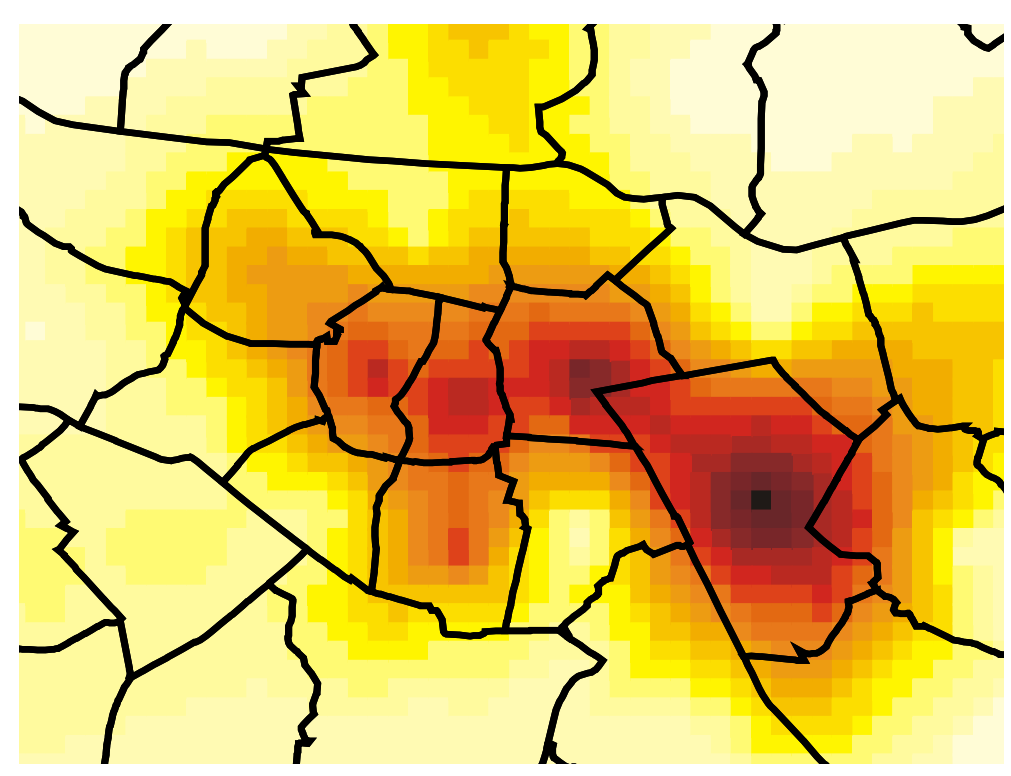

Mapa 2 - Inclusão e exclusão

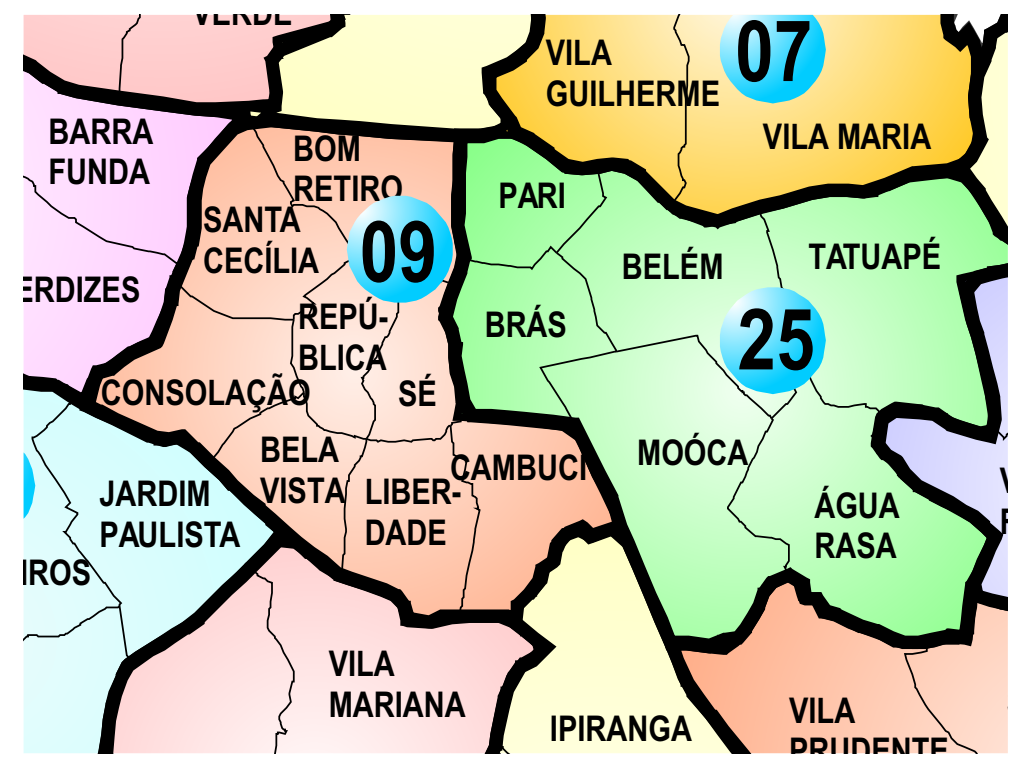

Mapa 3 - Inclusão e exclusão 


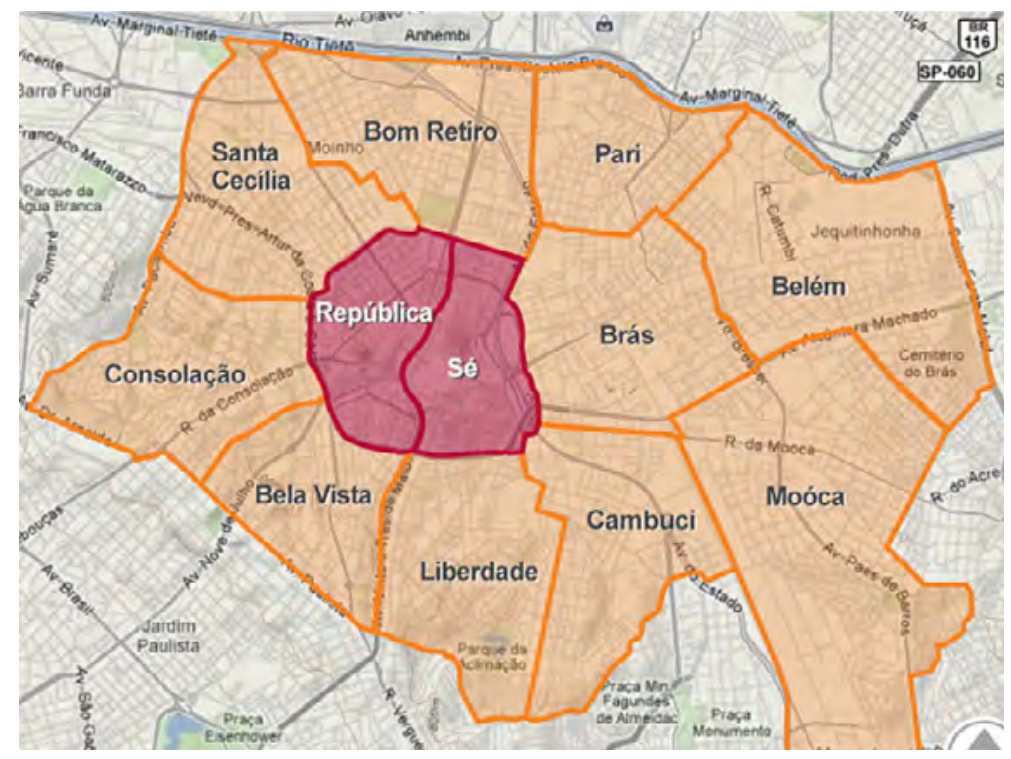

Mapa 4 - Área de abrangência do PROCENTRO

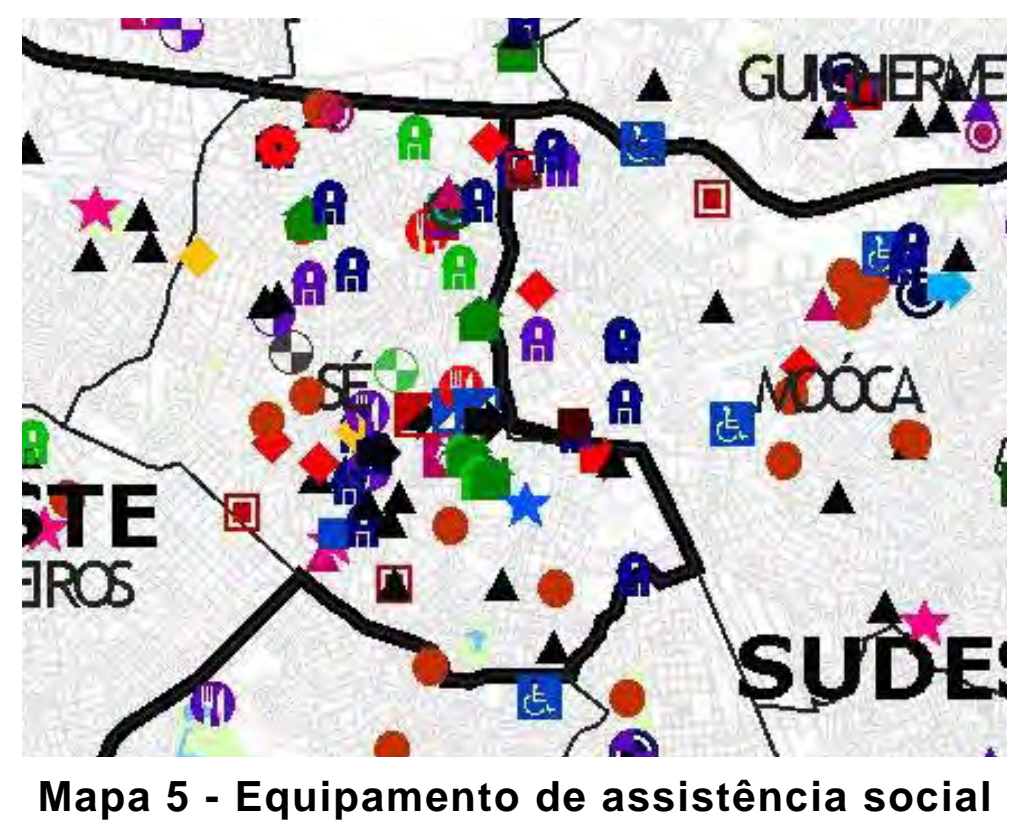

Dois fatos determinam o período em que se pesquisará a lógica do deslocamento dos moradores de rua. Primeiro, a observação de que entre 2002 e 2010 são encontrados dados com melhor qualidade, a população em condição de rua aumentou em 57\% em relação aos dados do ano 2000 e houve um número significativo de intervenções no centro histórico. Segundo, a existência de mudanças administrativas territoriais: em 
2002 houve a criação da Subprefeitura Sé, que iniciou o Programa de Reabilitação da Área Central; essas ações locais delimitaram o território a ser pesquisado e a sua área de abrangência. Portanto, o estudo foca a lógica dos deslocamentos de moradores de rua no período entre 2002 e 2010 nos distritos Sé e República (PROCENTRO).

O desenvolvimento da pesquisa será pertinente à lógica dos diferentes tipos de deslocamentos da população adulta em situação de rua e à relação de seus movimentos com as ações locais de assistência social e a requalificação da área central da cidade. Este estudo tem como premissa o deslocamento inerente do povo de rua, fato já conhecido como uma parte constitutiva de seu agir pelos teóricos da primeira metade do século XX (naquele momento, no entanto, os deslocamentos foram caracterizados como sem rumo ou destino). A pesquisa baseia-se no perfil atual do morador de rua da cidade de São Paulo, nascido a partir do desenvolvimento do urbano, quando as funções e os atores da cidade sofreram mudanças intrínsecas (LEFEBVRE, 2011, p. 54).

Os aspectos urbanos do agir dos adultos em situação de rua e sua relação com as funções urbanas da Cidade de São Paulo são o foco da pesquisa. São assinaladas também as ações das autoridades locais na Área Central, por relacionarem-se com o agir do povo de rua, seja pela existência da assistência social, seja pela requalificação dessa área. O urbanismo é a disciplina privilegiada da pesquisa, tendo como premissa a relação do agir dos moradores de rua com as funções urbanas no espaço público da cidade de São Paulo. Os conhecimentos a serem produzidos se ligam ao urbanismo; espera-se que os resultados contribuam a futuras pesquisas relacionadas com os moradores de rua no centro da cidade e à mobilidade nessa área. 


\section{OBJETIVO GERAL}

Determinar a relação dos deslocamentos territoriais dos adultos em situação de rua com as políticas de assistência social e requalificação, de 2002 até 2010, no Centro da cidade de São Paulo, especificamente nos bairros de Sé e República.

\section{OBJETIVOS ESPECÍFICOS}

Reconhecer a relação dos deslocamentos territoriais com o equipamento de assistência social nos bairros Sé e República.

Identificar a relação das políticas de assistência social e requalificação do solo com as variações na população adulta em situação de rua nos bairros Sé e República.

\section{PROBLEMA}

Os esforços da requalificação urbana e da assistência social, localizados no centro da cidade, constituem novos fatores para o deslocamento dos adultos em situação de rua dos distritos Sé e República; antes deles, aparentemente o deslocamento dessa população não tinha enfrentado fatores que o determinassem, sendo livre e sem curso. No período estudado, observam-se dois eixos de ações externos aos moradores de rua: por um lado um que puxa (assistência social) e por outro um que empurra (requalificação do centro), ambos com participação do setor privado e público. 


\section{ETAPAS DA PESQUISA}

\section{REVISÃO E ATUALIZAÇÃO DA BIBLIOGRAFIA EXISTENTE}

A etapa inicial da revisão bibliográfica permitiu orientar os primeiros passos da presente pesquisa. Buscaram-se estudos, pesquisas, dissertações e teses que tratassem do assunto dos moradores de rua. Foram utilizadas tanto fontes de informações primárias quanto secundárias, que tratavam ora de aspectos conceituais, ora de aspectos históricos do fenômeno de rua. Os recursos referidos na pesquisa bibliográfica foram extraídos de livros, revistas, vídeos, sites da internet, palestras e entrevistas. Uma vez obtidos, houve um trabalho de sistematização a partir de temas específicos. Para a discussão conceitual da dissertação, foram utilizadas fontes bibliográficas provenientes de diversas disciplinas (sociologia, arquitetura e urbanismo, entre outras), apresentando diferentes abordagens do fenômeno de rua. Um eixo que orientou a pesquisa foi a abordagem do fenômeno do urbano apresentado por Henry Lefebvre, a leitura das obras desse autor permitiu entender como se origina dito fenômeno no contexto da cidade atual, destaca-se especificamente a obra "O Direito à Cidade".

\section{BALANÇO DAS POSIÇÕES TEÓRICAS}

O fenômeno do povo de rua adquiriu novas características após o desenvolvimento do urbanonascidades, easconcepçõesteóricasrelacionadascomeleseconsolidaramapartir dosurgimentodasciênciasparcelares, especificamentedasociologia, essas ciênciassão 
chamadas assim já que "fragmentam a realidade a fim de analisa-la". Consideramse, na presente pesquisa, as posições teóricas existentes na primeira metade do século $X X$, especificamente as referentes às primeiras definições dos sem teto (homeless) propostas por Robert Ezra Parker, e as concepções dos primeiros censos de moradores de rua realizados na Cidade de São Paulo (LEFEBVRE, 2011, p. 43).

Ao avaliar capacidades, limites de compreensão, explicação e previsão dessas teorias e as mudanças no agir dos moradores de rua no século XXI, determinou-se a necessidade de uma nova abordagem teórica. A pesquisa propõe uma abordagem conceitual atual, pois essas posições teóricas passadas eram amplas e não se focaram nas particularidades do território pesquisado neste estudo. Pretendemos definir um conceito atualizado do povo de rua no presente estudo, apropriado para o contexto e o período pesquisado. Devem-se avaliar os limites de compreensão dos censos, fonte dos dados empíricos utilizados nesta pesquisa, pois, para fins do presente estudo, eles são considerados como o indicador da presença de moradores de rua na cidade. Entende-se que as cifras que eles produzem não são definitivas em relação ao número de pessoas em situação de rua, pois o caráter flutuante dessa população não permite que existam dados definitivos. Embora os censos não permitam conhecer com exatidão a população de rua, permitem identificar os territórios onde ela se concentra. Podemos estabelecer um paralelo entre a mancha urbana e a mancha do fenômeno de rua, já que cada uma indica no mapa onde esses fenômenos se estendem, note-se que ambas começam no centro da cidade. A analise desenvolvida na presente pesquisa, baseada nos mapas da prefeitura e no censo dos moradores de rua, permite identificar as variações da população de rua. 
A periodicidade é outra razão pela qual os censos devem ser considerados como indicadores da problemática, no sentido de localizarem aproximadamente os territórios onde ela se desenvolve. Embora os trabalhos estatísticos sejam realizados continuamente desde 1991, dia a dia pessoas entram e saem da rua, o que torna impossível conhecer-se com exatidão a dimensão do fenômeno. Os censos possibilitam a existência de uma espécie de radiografia da problemática de rua na cidade, mas os pesquisadores devem levar a conta o período da sua realização. As contagens indicam os territórios ocupados por um número expressivo de moradores de rua e não a quantidade exata de moradores de rua existente em cada território, pois a natureza heterogênea do fenômeno de rua não permite sua quantificação exata.

Este trabalho apresenta conceitos sobre o deslocamento da população pesquisada e os territórios da Área Central onde se desenvolvem, sendo esta a contribuição da pesquisa à sociedade. Ressalta-se que não existia até hoje outra pesquisa que reunisse os diferentes deslocamentos.

\section{PROCESSO DE COLETA DE DADOS E INFORMAÇÕES}

Os elementos empíricos do objeto concreto recortado, constituídos em sua maior parte pela informação dos censos dos moradores de rua no centro da Cidade de São Paulo no período de 2002 a 2011, foram sistematizados, analisados e interpretados por meio de gráficos, tabelas e mapas. O resultado é um conjunto de conhecimentos específicos sobre essa população de rua que, na medida do possível, reproduz o objeto de pesquisa e sua problemática sob a ótica do urbano. 


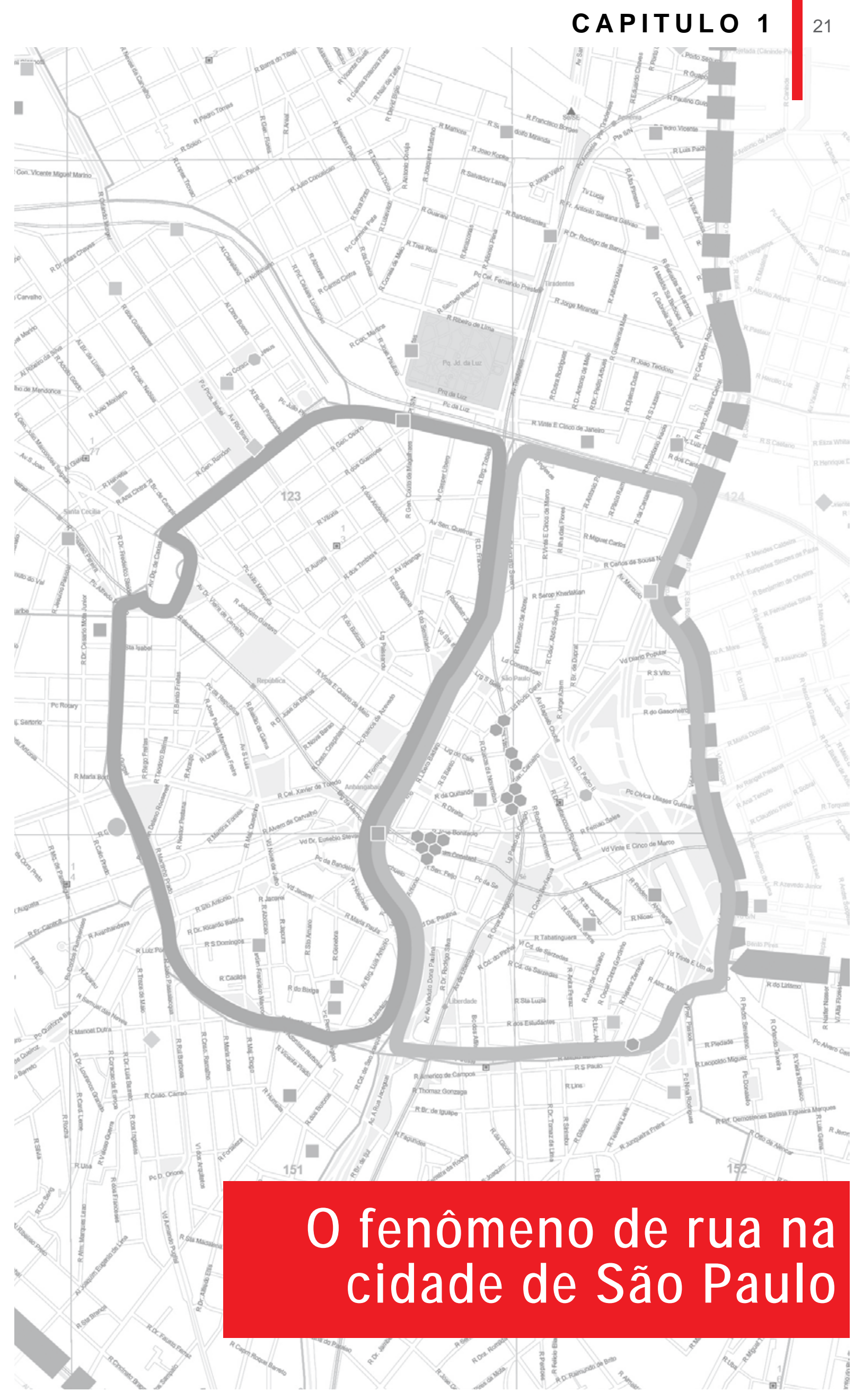




\subsection{OS MORADORES DE RUA NA CIDADE}

O fenômeno dos moradores de rua nas cidades não é exclusivo do século XXI, pois o conceito do homem livre, que data do Brasil colonial, se relaciona com pessoas sem emprego ou ganhos fixos que têm poucos recursos para se sustentar. Nessa época, a abundância das terras disponíveis possibilitou às pessoas subsistir com os recursos que encontraram no campo, coletando frutos ou produzindo para autoconsumo. $\mathrm{Na}$ época que antecedeu a Revolução Industrial, na época da escravidão, havia também uma população sem emprego, que desenvolvia estratégias variadas para subsistir. Ofereciam serviços pessoais autônomos a fim de obter sustento, mas esses trabalhos temporários faziam com que eles ficassem sem dinheiro e por tanto na rua. A Era Industrial, por sua vez, seria marcada pelo uso da máquina, deixando-se de lado a força física do homem e fazendo surgir na cidade um contingente ainda maior de pessoas livres e pobres. A inserção do pobre à força de trabalho da indústria foi difícil, assim como a aceitação pela população em geral dos bens e serviços de primeira necessidade, que, para muitos, era algo novo.

No Brasil, a crescente população de rua do século XIX não passou despercebida, o que se pode depreender do fato de as autoridades começarem a controlar a "vadiagem" de maneira consistente. Eram considerados "vadios" aqueles que estavam na rua sem fazer nada ou de folga. As medidas tomadas eram agressivas: aqueles que não conseguiam comprovar um meio de subsistência eram considerados "vadios" e colocados em trabalhos forçados. As autoridades obtiveram dessa maneira a mão de obra para os melhoramentos urbanos da época. 
Essa norma foi desaparecendo gradativamente, mas no contexto legal se manteve vigente até a Constituição de 1988, momento no qual foi eliminada oficialmente mesmo que na prática já tivesse sido esquecida por muitos. Ao longo do século $\mathrm{XX}$, o fenômeno de rua adquire gradativamente as características que conhecemos hoje. Na década de 50, os moradores de rua na cidade eram vistos por alguns como encantadores e atraentes, com uma vida que parecia idílica, retratada na música e literatura. Hoje é uma realidade chocante e cruel, localizada no centro da cidade. Na década de 60 no contexto brasileiro, registram-se 30 milhões de pessoas em condição de miséria; na década de 70, 45 milhões. Ao longo da década de 80 , 0 fenômeno dos moradores de rua torna-se uma problemática da cidade de São Paulo, agudizado pela crise econômica. Chegam à rua pessoas recém-desempregadas ou cujas condições econômicas não permitiam o acesso a condições de moradia digna. A sua presença foi paulatinamente percebida nas calçadas, jardins, viadutos, praças e parques (SIMÕES, 1992, p. 11).

No caso do território pesquisado, o panorama é complexo; só no centro da cidade de São Paulo pode-se encontrar essa mistura única, rica em arte, comércios e serviços. No Centro reúnem-se extremos: moram tanto as pessoas mais ricas e reconhecidas da sociedade paulista quanto a população mais pobre. Nesse contexto, o fenômeno dos "moradores de rua" é percebido com facilidade. A proliferação da população em condições de pobreza extrema se relaciona com o aumento da dívida externa, a inflação crescente, os constantes ajustes econômicos e a drenagem de recursos para o exterior que começaram na década de 70. A crise financeira e do comércio internacional que se iniciou nessa década teve uma abrangência mundial e, na América 
Latina, registra um sensível aumento da pobreza. No Brasil sentimos os efeitos da crise do petróleo de 1973-1974; o súbito aumento do preço do petróleo tem como consequência a redução de investimentos tanto no setor público quanto no setor privado. O setor público deixa de investir paulatinamente em projetos de ordem pública em todo o Brasil: "aliado a esse momento recessivo, soma-se ainda a crise por que passou, desde o início dos anos 80, o sistema financeiro da habitação e a política de produção de moradias populares" (SIMÕES, 1992, p. 13).

A cidade de São Paulo passou por circunstâncias particulares. O setor mais afetado foi o industrial, que, desde a década de 50, fora o setor mais dinâmico da cidade; na década de 70 , tinha quase a metade da força de trabalho industrial do estado; na década de 90, tinha menos de um terço. Essa drástica redução da força de trabalho foi acentuada na capital do estado. São Paulo passou por "uma significativa recessão econômica e por uma mudança na estrutura de suas atividades econômicas", que continuou nas décadas de 80 e 90. As consequências foram facilmente percebidas na cidade; a primeira foi o abandono ou conversão de fábricas - essas mudanças na infraestrutura da cidade geraram espaços urbanos propícios à degradação. Bairros da cidade que eram frequentados por trabalhadores e provedores foram subitamente abandonados e então outros grupos da população apropriaram-se deles. A segunda consequência da crise foi a criação de novos tipos instalações comerciais e de serviços na cidade. Tendo poucos recursos, o setor público se concentra na política de expansão da cidade, e os investimentos feitos pelo setor privado se direcionam a áreas fora do centro velho. Nesse momento surgem novas centralidades, os setores públicos e privados favoreceram a tendência de expansão horizontal da cidade em 
direção a esses logradouros: para a Avenida Paulista, Pinheiros e Avenida Faria Lima sucessivamente. Essa expansão horizontal no território possui algumas zonas densas caracterizadas pela infraestrutura de boa qualidade. Nesses novos espaços urbanos, implantaram-se complexos de edifícios de escritórios, conjuntos habitacionais, shopping centers e hipermercados (PIRES, 2003, p. 249).

A terceira consequência da crise foi que os residentes que procuravam novas opções de moradia saíram do centro da cidade, indo junto com eles uma parte da população que procurava emprego ou oportunidades de investimento. As políticas públicas de moradia concebiam programas sociais para famílias que tinham menos de três salários mínimos, deixando à crescente população em condição de pobreza extrema opções limitadas de moradia: favelas, cortiços ou a rua. Perpetua-se, nessas décadas, o esvaziamento do centro da cidade, gerando o cenário onde se desenvolveria o crescimento do fenômeno de rua. No processo do enfrentamento à crise, ocorreu uma reestruturação econômica e um reajustamento social, mas o resultado disso foi um novo padrão de acumulação, que teve como consequência mudanças no mundo do trabalho que afetariam milhares de pessoas, levando o fenômeno a proporções nunca antes registradas. Na década de 90, o declive econômico continua, "a agudização de recessão conduziria outros grupos de desempregados para a situação de morar e sobreviver na rua". Nessa década, registram-se 60 milhões de brasileiros classificados como miseráveis. Estatisticamente considera-se miserável o cidadão cuja renda familiar é inferior ao salário mínimo (SIMÕES, 1992, p. 11, 13). O problema agudiza-se após a promulgação do $1^{\circ}$ Plano Econômico do governo Collor (1990). A consequência imediata foi a paralisação dos investimentos e dos trabalhos no setor 
de construção civil. Um grande número de trabalhadores foram dispensados dos projetos em curso. A consequência da crise econômica dessa década foi a ampliação do fenômeno de rua no Brasil. As mudanças no mundo do trabalho em toda a nação só aumentaram a problemática; nesse período se registram altos níveis de desemprego. No final dessa década, a população de rua em São Paulo chegaria a 100 mil pessoas. O panorama crítico do fenômeno de rua no decênio de 1990 motiva as autoridades locais a iniciar os censos de moradores de rua, a fim de se ter uma ideia mais clara da problemática. Até o início dessa década, existiam poucos dados do fenômeno de rua na cidade de São Paulo; até então, os pesquisadores guiavamse apenas por observações empíricas. A ideia do censo foi a de se fazer um trabalho exploratório, realizado pelos técnicos e estagiários da Secretaria Municipal do BemEstar Social (hoje SMADS) e das entidades que trabalhavam com a população de rua. Às observações empíricas juntaram-se os preparativos de quase três anos para que se delimitasse a área a ser pesquisada: "o levantamento abrangeu as regionais da Sé, da Lapa, de Pinheiros e parte das regionais da Mooca, da Penha, do Ipiranga, da Vila Mariana e de Santana e foi realizado na primeira quinzena de maio de 1991" (VIEIRA / BEZERRA / ROSA, 1992, p. 49).

Essa primeira contagem foi baseada em informações de "comerciantes e moradores próximos aos pontos de pernoite a respeito do período de tempo que vinham sendo ocupados, obtendo-se informações sobre apenas 162 pontos". As ações procuravam identificar os espaços públicos do centro que eram utilizados pela população de rua, levando-se em consideração o caráter temporário do uso e a frequência. As contagens eram realizadas durante as noites, procurando-se os pontos de pernoite; fizeram-se 
entrevistas diurnas com os vizinhos e comerciantes para completar a informação. Deixaram-se de fora os prédios abandonados e invadidos, assim como os depósito de papelão, mesmo sendo esses locais pontos de pernoite importantes na cidade - e nessa época eram 3 mil (VIEIRA / BEZERRA / ROSA, 1992, p. 48).

As contagens iniciadas na década de 1990 concentraram-se na área central da cidade. Os primeiros resultados não foram os esperados, pois pensava-se que as ruas albergavam 100 mil moradores de rua. No momento em que a cidade foi pesquisada em sua totalidade, os resultados deram uma ideia mais aproximada da realidade. Em 1993, as autoridades locais concentraram-se nas crianças em situação de rua, e revelaram que se reproduz em certo nível a mesma dinâmica que na população adulta, pois predomina o gênero masculino nesse grupo etário. Um dos traços que se mantêm é a concentração do povo da rua na área central. Tanto as primeiras contagens quanto os primeiros estudos da população de rua da década de 90 impulsionaram a visibilidade do fenômeno de rua. Deixaram-se as especulações para trás, pois os dados assinalavam uma condição de alarmante aumento. Antes das contagens, existiam teorias fragmentadas que conduziam à responsabilização dos indivíduos por sua condição de rua, isentando a perpetuação das desigualdades sociais. O resultado dessas deduções iniciais foram as estratégias de enfrentamento fragmentadas, que não trouxeram solução ao fenômeno de rua. Após uma década de censos, surgiram os efeitos da onda recessiva da década de 90. A drástica redução dos postos de trabalho na indústria e construção teve como consequência o agravamento do desemprego e do trabalho precário. No período de 2000 a 2005, os censos evidenciam que uma grande parte da população em situação de rua era de 
origem urbana. Existe uma relação entre o desemprego estrutural, a condição de rua e as mudanças positivas nos indicadores de crescimento da economia.A visibilidade do fenômeno de rua e o interesse dos acadêmicos teve como resultado o primeiro encontro sobre população em situação de rua em 2005. Iniciam-se contagens em outras cidades brasileiras como Belo Horizonte e Recife no mesmo ano. A Lei 11.258, emitida no mesmo ano, torna obrigatória a elaboração de programas direcionados a esse grupo populacional; isso teve repercussões imediatas na rede de assistência social. Criam-se os primeiros projetos de inclusão produtiva na perspectiva da economia solidária. À medida que as contagens foram implementadas em mais cidades do Brasil, as peculiaridades de cada contexto foram evidenciadas. Por exemplo, no Recife o fenômeno é caracterizado por um número maior de pessoas jovens do que em São Paulo e em Belo Horizonte.

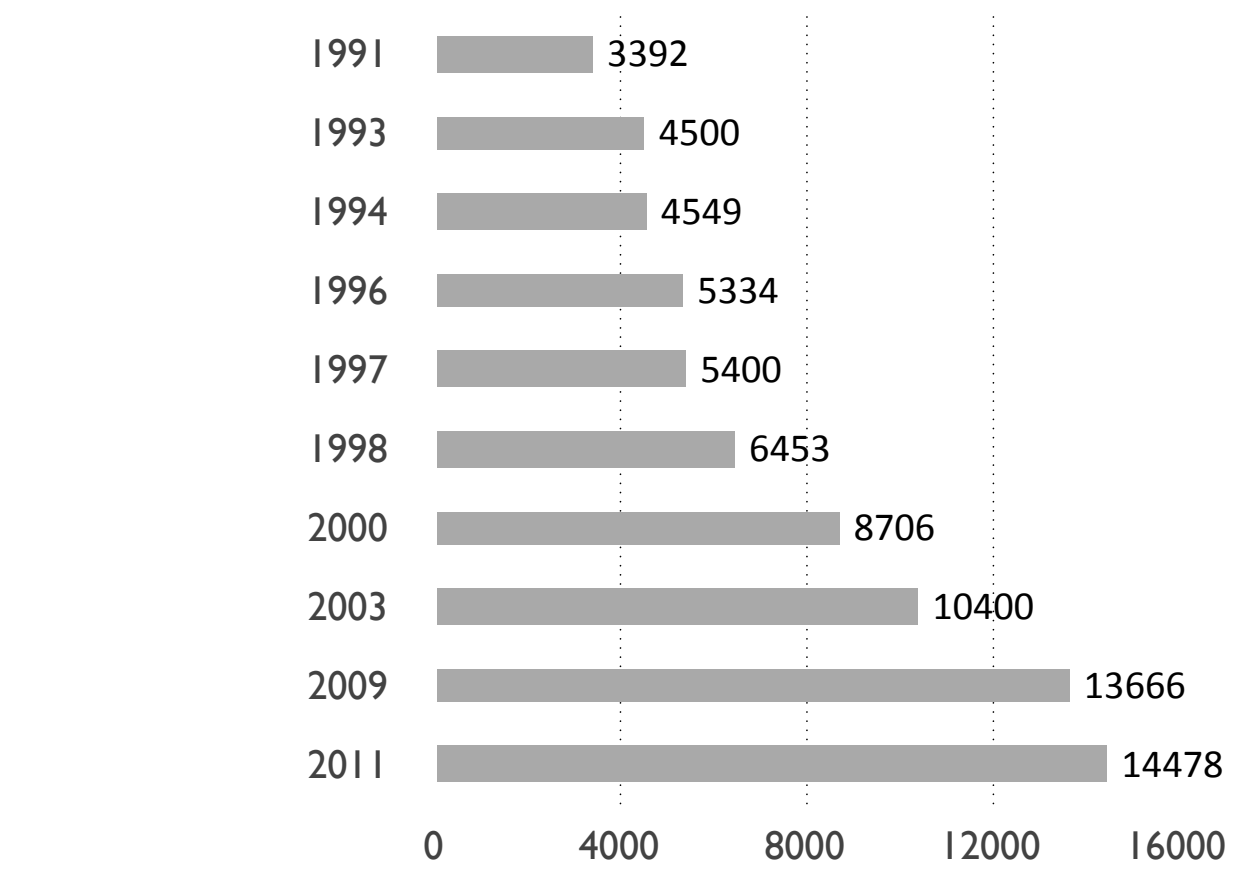

Gráfico 1 - Censos dos moradores de rua da Cidade de São Paulo 


\subsubsection{ANTECEDENTES DO FENÔMENO}

Morar na rua, no entanto, "quer seja por opção ou por falta de opção, não é um fenômeno dos tempos contemporâneos". Desde a antiguidade, há registros de pessoas morando nas ruas das cidades. Os primeiros nos levam à Grécia Antiga. Mudanças na sociedade arcaica, como a consolidação da propriedade privada e a expropriação de terras comuns, geraram condições econômicas que propiciaram pobreza extrema e migrações internas. Grupos de pessoas em condições de pobreza viajavam aos centros da época, procurando sustentar-se através da mendicância e de trabalhos temporários (SIMÕES, 1992, p. 19).

Posteriormente, em Roma se repetem condições semelhantes; os territórios conquistados - produtos dos empreendimentos bélicos - apresentavam migrações em grande escala. Os doentes, os camponeses sem terra, os escravos, as vítimas de guerras e os soldados residuais dos exércitos divididos, constituem um contingente de população em condição de extrema pobreza com profundas diferenças sociais e culturais. A mendicância e a vadiagem foram práticas comuns nessa época; parte dessa população desvalida realizou deslocamentos longos e temporários. Os primeiros registros de moradores de rua, em distintas sociedades através dos séculos, estão relacionados com a mendicância. Na Europa da Idade Média, tornase uma profissão; além do sustento, gera ganhos com fins de poupança. As crenças religiosas da época faziam da pobreza uma virtude; era um estilo de vida idealizado que fazia dos mendigos uns "santos". Ao se perceberem os ganhos dessa atividade, criou-se uma metodologia de mendicância, com técnicas e linguagem específicas que 
se relacionavam a territórios pontuais nos centros europeus. A acumulação primitiva das cidades feudais fez comuns as expropriações de terras rurais, assim muitos camponeses ficaram sem fontes de subsistência, o que era seguido por grandes migrações. O pensamento da Renascença mudou a concepção de "mendigo", pois, a partir do século XIV, os valores religiosos e humanistas passaram a denegrir a pobreza. Independentemente disso, a cidade pré-industrial se caracterizava pela mendicância; pessoas empobrecidas e sem vínculos organizacionais eram conhecidas como "população flutuante". Na época, as autoridades não demoraram em reagir ao aumento de moradores de rua, e um exemplo disso foi a Lei de Vadiagem criada na Inglaterra em 1349 ou o Liber Vagatorum de Martinho Lutero, publicado em 1528.

Do pauperismo da Europa Ocidental, no final do século XVIII, surge esse contingente de pessoas que, ao serem desapropriadas, trasladaram-se aos centros urbanos da época na procura de alternativas de trabalho, na sua maioria precárias. Paralelamente a isso, geraram-se as condições necessárias à produção capitalista, e é nesse período que o fenômeno de rua assume a maioria das características que conhecemos hoje. Na França do século XIX, registram-se grupos de moradores de rua organizados, cuja prática de sobrevivência se relacionava com a mendicância profissional. Seus locais de reunião eram os gueux, que constituam seu domicílio e esconderijo. Estes locais ficavam próximos às áreas comerciais e eram superlotados, apresentando condições bem precárias. As reuniões regulares eram imprescindíveis para discutir o trabalho e os territórios. Nos escuros e afastados geux, registram-se orgias e outras práticas consideradas viciosas. Simular doenças e incapacidade física era parte da metodologia dos pedintes. Os gueux eram conhecidos como "pátios de milagres", 
já que, ao entrar neles, as doenças desapareciam. As fraudes dos pedintes iam além da rua; há registros de que alguns monges recrutavam pessoas dos gueux para seus milagres; em troca, elas ganhavam a proteção do clero. Nas cidades norteamericanas do início do século $\mathrm{XX}$, os setores da cidade onde se agrupavam os "hobos" (vagabundos), os "homeless" (sem lar) e os boêmios eram conhecidos como Hobohemia. Esses setores especializados possuíam os serviços de que a população pobre precisava: moradia temporária, alimentação barata, bares e agências de emprego. A maneira como se desenvolveram suas atividades até a chegada da Grande Depressão ficou fixada no imaginário tanto dos estadunidenses quanto do resto do mundo, devido aos retratos plasmados no cinema, na literatura e na música.

\subsubsection{O CONCEITO DO MORADOR DE RUA NO SÉCULO XX}

Em contextos de desigualdade social e econômica, apresentam-se pessoas com condições de pobreza extrema e circunstâncias de vida particulares que optam por utilizar os espaços públicos como alternativas de sobrevivência e moradia; elas são conhecidas como 'moradores de rua'. É o que acontece em cidades com grande riqueza econômica e ausência de equidade: geram-se condições precárias para porções da população. O fenômeno não é novo, nem exclusivo das sociedades capitalistas, já que se apresenta nas aglomerações urbanas antigas. No começo do século XX, a criação das ciências parcelares, como a sociologia e a psicologia, permite o estudo dos fenômenos sociais a partir do indivíduo, já que a pesquisa académica "fragmentase segundo as especialidades". 
Após anos de reflexão sobre o fenômeno da rua, hoje se sabe que as condições sociais e econômicas de uma cidade ou país aliam-se à incapacidade do indivíduo de enfrentar os desafios da pobreza extrema, produzindo um contingente de pessoas que moram na rua. Em outros casos, geraram-se enormes contingentes de pessoas que se deslocaram, em menor ou maior escala, por causa de fatores externos como os conflitos armados. Os desastres naturais também podem criar situações inesperadas; nesses contextos, uma grande quantidade de pessoas mudam sua vida drasticamente. As características particulares dos territórios podem ter relação com a maneira como o fenômeno de rua se desenvolve, pois nas cidades litorâneas, por exemplo, se experimentam mais influxos de pessoas pobres (LEFEBVRE, 2011, p. 43).

Paralelamente aos estudos da sociologia, gera-se um conceito romântico do morador de rua no cinema. É assim que se fixa a imagem do indivíduo velho, viciado, sem rumo e boêmio. Nos Estados Unidos, esse personagem foi "Carlitos", interpretado por Charles Chaplin. O escritor, diretor e intérprete chamava seu personagem de "vagabundo". Outra representação significativa do fenômeno da rua foi "As Vinhas da Ira", de John Steinbeck, livro que retrata as condições de pobreza que motivaram muitas famílias a vender suas propriedades e migrar. Essa importante obra literária foi adaptada ao cinema, o que forneceria a imagem do norte-americano de classe trabalhadora. A obra literária captura um momento significativo, mostrando chegarem à rua famílias e crianças, ficando claro que a Grande Depressão mudou o fenômeno de rua. A cidade de São Paulo contava com seu próprio ícone no cinema, do filme "Candinho", de 1954, dirigido por Abílio Pereira de Almeida: o personagem "Professor 
Pancrácio", interpretado por Adoniran Barbosa. Esse personagem usa fantasias de mendigo para enganar os transeuntes e obter ganhos. Para muitos, "retrata de forma ideal esse modo de vida adotado por aqueles que exerciam a mendicância com o fim de poupança; descrevia o individuo que (...) por contingências de vida tudo havia perdido e passou a viver da esmola alheia" (SIMÕES, 1992, p. 23).

O salto entre essa imagem romântica e a crua realidade do povo de rua dos anos 90 foi grande; nesse período, consolidaram-se os traços que hoje conhecemos do fenômeno. No decênio de 1980, as características dessa nova população de rua já tinham mudado. Primeiro, mudou a composição etária, pois surgiram mais jovens morando nas ruas. Segundo, nas ruas encontravam-se pessoas de diferentes etnias. Terceiro, às populações tradicionais adicionaram-se mulheres e crianças, passou a haver núcleos familiares completos em situação de rua. Quarto, o fenômeno adquiriu uma visibilidade nova, pois o resultado das renovações urbanas foi a destruição de seus nichos, acontecendo uma mobilização que teve como consequência aumentar a frequência do contato dessa população com outros atores (SNOW / ANDERSON, 1998, p. 42).

O início da pesquisa desenvolvida pela Prefeitura sobre o fenômeno de rua na cidade de São Paulo, na década de 90, começa com um conceito amplo, longe do conceito do vagabundo romântico dos 50. Baseou-se no conceito de "homeless" ou "sem lar", ou seja, a pesquisa abrangia não só os que viviam na rua, mas também os que estavam em habitações que não atendiam a necessidades e padrões mínimos de habitabilidade. Foi assim que inicialmente se considerou como moradora de rua 
a população que habita cortiços e favelas. A premissa inicial de "desabrigado" foi genérica, por conseguinte estabeleceram-se subcategorias que foram pesquisadas a fundo nos anos seguintes. O conceito inicial de "desabrigado" foi deixado para trás no desenvolvimento da pesquisa da Prefeitura. No decênio de 1990, o fenômeno foi aclarado; o conceito do morador de rua delimitou-se excluindo a população em condição de moradia precária, seja de cortiço, seja de favela. Definiu-se inicialmente o fenômeno de rua como um estilo de vida caracterizado pela ausência de moradia convencional, formal e permanente. Por meio dos trabalhos de estudiosos nessa década, entende-se que: “(...) ocorre que a agudização da pobreza em momentos conjunturais de maior desemprego e arrocho salarial gera, em proporções crescentes, a ocupação de lugares públicos como estratégia de sobrevivência e moradia" (VIEIRA / BEZERRA / ROSA, 1992, p. 13).

A partir da década de 90 , os dados dos moradores de rua passaram de observação empírica a uma realidade certeira, esse é o aporte mais importante dos censos de moradores de rua que se iniciaram em 1991. Foi por meio deles que os estudiosos brasileiros obtiveram dados substanciais do fenômeno da rua das cidades brasileiras. No início se reconheceu que as condições nas quais se desenvolveu o fenômeno de rua tinham propiciado o crescimento e a cristalização da situação de rua em São Paulo; além da tradicional mendicância, apresentavam-se novas dinâmicas que precisavam ser registradas. O início das pesquisas constantes foi uma forma de reconhecer a existência de uma porção da população cujas condições econômicas estão nos limites inferiores de pobreza e vulnerabilidade, o que produz a desestruturação residencial temporária ou permanentemente. Parte dessa população possui um grau tão baixo 
de escolaridade que, mesmo estando numa idade economicamente ativa, não conseguem inserção no mercado de trabalho formal. Ao avançar com a pesquisa, reconhece-se o caráter heterogêneo da população em condição de rua, entendendo como parte dela quem entra e sai da rua à medida que suas condições econômicas o permitem: "em função de suas condições de vida, tais pessoas podem alternar a rua com outras situações habitacionais precárias e o trabalho de bicos na rua com um trabalho regular". A complexidade da vida na rua foi emergindo aos poucos; os pesquisadores passaram a reconhecer tanto seu caráter temporário quanto os deslocamentos em diferentes escalas que formam parte do fenômeno de rua (VIEIRA / BEZERRA / ROSA, 1992, p. 48).

O fenômeno de rua, como o conhecemos hoje, deve ser entendido como heterogêneo, emergente e mutável, por isso apresenta grandes desafios para os pesquisadores. A natureza flutuante da população de rua deste século fez com que poucos pesquisadores estabelecessem poucos parâmetros confiáveis de avaliação. Alguns pesquisadores afirmam que a vida na rua não se presta a contagens padronizadas, no estilo dos censos, ainda que outros pesquisadores tenham procedido dessa maneira. Ser um "morador de rua" trata-se mais de uma identidade invertida, pois ela é constituída pela perda de todos os valores e conceitos da sociedade formal, definida pela exclusão do resto da população em geral. Existem muitos termos que foram utilizados para denominar essa população; cada um possui uma ótica particular; o desenvolvimento das pesquisas das décadas de 1980 e 1990 deixam uma bagagem de ideias relacionadas com o fenômeno de rua: 
Nomes atribuídos pelos

pesquisadores brasileiros

Em relação à moradia

Em relação à condição social

Em relação à seus deslocamentos
Moradores de rua, povo da rua, pessoas em situação de rua, homem de rua, integrante da população de rua, indivíduos em situação de rua e população em condição de rua.

Homeless, sem teto, sem casa e sem lar

Outsider, desabrigado, caído, indigente, mendigo, pedinte, trecheiro e fracassado.

Andarilho, nômade urbano, recém deslocado, vacilante e recém chegado.

\section{Tabela 1 - Denominações atribuídas aos moradores de rua}

Na presente pesquisa, são denominados "moradores de rua" o conjunto de pessoas que, seja por circunstâncias fora de sua vontade, seja por limitações pessoais, se vêm obrigadas a morar nos espaços públicos da cidade. Mesmo que essa denominação se refira à situação de moradia, tem relação com a ausência de recursos econômicos, a carência de residência convencional, o desemprego e a perda dos laços familiares. Nessas circunstâncias, o indivíduo se dirige à rua, logo o espaço público da cidade adquire um novo significado e torna-se em seu espaço vital, aquele onde ele desenvolve seu cotidiano. Ele carrega consigo tudo o que possui.

Essa complexidade faz com que morar na rua seja uma condição que está além da negligência do problema habitacional na cidade, já que tem relação com forças estruturais, migrações internas, desagregação familiar e outros fatores além da condição de moradia. Em conjunto, os moradores de rua constituem uma população heterogênea, sem padrões gerais mas com algumas tendências, compartilhadora de alguns elementos comuns e vinculantes que os definem. A única tendência comum, 
que se identifica até hoje, é a do crescimento constante e continuo da população, especificamente nas áreas centrais das cidades. Mesmo com toda a heterogeneidade, as diferenças entre indivíduos participantes dessa população não são reconhecidas tão facilmente. Na presente pesquisa escolheu-se utilizar o termo "adultos em situação de rua" em referencia ao objeto de estudo, isso a fim reivindicar o papel desses indivíduos, em virtude a que se reconhece seu valor e aporte criativo, eles podem reivindicar, se escolherem, sua condição no contexto da sociedade brasileira. Mesmo assim se utiliza o termo "moradores de rua" para referir-se ao total da população em situação de rua.

\subsubsection{TRES PERFIS PREDOMINANTES DENTRO DA POPULAÇÃO DE RUA}

Contrariamente à opinião corrente, a maior parte da população de rua não é dependente de substâncias lícitas ou ilícitas. Tanto documentários como estudos sobre os moradores de rua revelaram gradativamente o caráter heterogêneo da população. Hoje se sabe que a população de rua é constituída principalmente por pessoas do sexo masculino em idade economicamente ativa, em faixas etárias mais elevadas, principalmente entre 25 e 55 anos. Existem mulheres dentro da população de rua, numa porção reduzida, composta por diferentes grupos etários. Identificam-se tanto expectativas diferenciadas em relação à vida na rua, quanto diferentes maneiras como os indivíduos se inserem nela. Não existe um único fator determinante que leve os indivíduos a uma situação de rua, embora exista uma conjunção de fatores. 
Para que uma pessoa passe a morar na rua, conjugam-se tanto fatores estruturais (ausência de moradia, desemprego, mudanças econômicas e sociais no seu contexto) quanto fatores biográficos (características individuais: histórico familiar, doenças, dependência de substâncias, infortúnios pessoais, etc.), o que faz variados os caminhos que levam as pessoas a uma vida na rua. Em casos excepcionais, existem fatos da natureza ou desastres de massas, que, em conjunção com os dois fatores assinalados, fazem com que um contingente de pessoas se voltem à rua. Ao examinar os dados produzidos pela Pesquisa Nacional dos Moradores de Rua -PNMR- de 2009, sabe-se que existem três perfis predominantes de indivíduos que escolhem a rua como opção de vida: "Os principais motivos por eles apontados se referem a [Perfil 1] problemas de alcoolismo e/ou drogas (35,5\%); [Perfil 2] desemprego (29,8\%) e [Perfil 3] desavenças com pai/mãe/irmãos [familiares] (29,1\%)". Dos entrevistados na PNMR, 71,3\% indicaram pelo menos um dos três motivos assinalados (QUIROGA / RODRIGUEZ -org-, 2009, p. 87).

Perfil 1: O caído. Conhece-se como "caído" o indivíduo que se entregou totalmente ao consumo de alguma substância, seja drogas, seja álcool; o uso de agentes causadores de dependência não é um padrão geral, mas uma parte da população apresenta essa tendência. As pesquisas mostram que na realidade o consumo de bebida e de substâncias são motivo de conflito entre a população de rua. Os moradores de rua que não são dependentes se mantêm longe dos agrupamentos em que o consumo é predominante. Essa segregação é tal que alguns moradores de rua consideram os "caídos" como a classe mais baixa dentro da pirâmide social da rua, evitando contato com eles. 
À primeira vista, a bebida pareceria parte do "modus vivendi" dos moradores de rua, sendo um dos traços definidores centrais da subcultura dos homens moradores de rua; mas, embora a maioria beba, nem todos os homens que moram na rua são alcoólatras. O álcool é considerado como um elemento socializador na rua, pois, ao compartilhar-se uma bebida, consegue-se integrar grupos fragmentados de moradores de rua. A garrafa de cachaça, conhecida também como pinga ou branquinha, parece a alguns a companheira inseparável, seja para suavizar o desconforto, seja para apagar a solidão. O álcool é na rua um analgésico social, pois possibilita aos indivíduos liberarem-se das regras convencionais da sociedade formal, o que facilita sua inserção na rua. Deve assinalar-se que, para alguns, o álcool foi um problema anterior à vida de rua e um dos motivos do afastamento da família; para outros, surge com a ida para a rua. A dependência ao crack pode parecer uma característica muito comum dos moradores de rua, esse é um dos preconceitos mais generalizados que se tem sobre essa população. Não são todos os moradores de rua que consomem drogas, e a maioria do povo de rua que consome crack concentra-se no território conhecido como "cracolância" (não deixando de existir fora dessa área pessoas em situação de rua que consomem essa e outras substâncias). Por constituir a droga mais barata, consideram-se seus usuários, dentro da população de rua, como os mais pobres. Na realidade, tanto o grau de dependência, quanto a deterioração física que essa droga produz impossibilita que esses usuários consigam desenvolver alguma das estratégias de sobrevivência. É um circulo vicioso, no qual o dependente de crack parece perder-se.

O consumo de substâncias remete a uma espécie de "economia. da rua", pois o preço 
da droga tem completa relação com o consumidor, com sua capacidade de pagamento e consumo. O preço do crack nas ruas pode oscilar entre $R \$ 1$ e $R \$ 13$, em torno do qual giram muitas atividades que geram lucro nesse contexto, pois existe a prostituição de mulheres e de menores que, dentro da população de rua, mantêm uma tarifa nessa faixa de preços por seus serviços. É diferente o caso dos moradores de rua com ingressos maiores; mesmo que estes sejam irregulares, com eles podem adquirir drogas mais caras e de melhor qualidade. Esse tipo de usuário é conhecido como "funcional"; embora consuma, ele não é afetado pela dependência que essas substâncias produzem, portanto não será um dos caídos. Em geral, a dependência a substâncias, sejam lícitas ou sejam ilícitas, é considerada pelos pesquisadores como a principal dificuldade no processo da reinserção à sociedade. O uso regular dos albergues implica não beber ou drogar-se, pois um dos requerimentos para o uso desses equipamentos é a sobriedade dos usuários. É clara a divisão entre aqueles que consomem e os não consomem drogas entre a população de rua; os "caídos" se resignam a pernoitar ao relento ou simplesmente não utilizar a assistência social. Observa-se que os "caídos" têm a possibilidade de acudir ao equipamento especializado nos diferentes tipos de dependência, como o Centro de Atenção Psicossocial III Álcool e Drogas (CAPS III AD). Perfil 2: O desempregado sem teto. Uma parte da população de rua se constitui de pessoas economicamente ativas: "trabalhadores sistematicamente expulsos do mercado de trabalho e visivelmente presentes nas ruas da cidade". Para uns, esse tipo de vida foi a única opção em circunstâncias de pobreza extrema: "a rua transformou-se então, para esses operários de construção civil, na sua única alternativa de moradia" (VIEIRA / BEZERRA / ROSA, 1992, p. 12 / SIMÕES, 1992, p. 13). 
Na recessão econômica das décadas de 70, 80 e 90, um contingente de pessoas formadas ou especializadas estavam sem emprego na cidade de São Paulo. Grande parte dessa população ficou exposta às condições precárias do mercado informal de trabalho ou à falta de emprego. Geraram-se nessas décadas dificuldades para a sobrevivência das pessoas com baixos recursos, o que lhes leva gradativamente aos setores informais de moradia: multidões ${ }^{1}$, favelas, cortiços, pensões e a rua. Tendo condições irregulares de trabalho, eles entram e saem da vida na rua, o que indica que, para uma parte dessa população, morar na rua não é uma condição fixa, mas temporária: "dentro desse grupo se encontra um contingente que pode ser caracterizado pela extrema mobilidade. Além de ter trabalho irregular, não possui residência fixa e nem convivência permanente com o grupo familiar". Nesse perfil observa-se a predominância do gênero masculino; em sua maioria são homens em idade ativa que chegaram à cidade procurando emprego. À busca de melhores condições de vida, eles não conseguiram inserir-se no mercado laboral formal ou fixo, acarretando, consequentemente, a superlotação do mercado informal de trabalho (VIEIRA/BEZERRA/ROSA, 1992, p. 22).

Por conseguinte, este homem, "ao perder o emprego, esgota todas as possibilidades econômicas, perde a moradia, a possibilidade de comunicação com o mundo" e apresenta uma "desvinculação social". Essa perda não é imediata; a transição aos setores informais de trabalho e moradia, na maioria dos casos, é gradativa. A rua torna-se um destino para os desempregados, em função de várias circunstâncias. Às vezes a escolha da rua está relacionada a fatores externos, como conjunturas que restringem emprego e moradia. Devem considerar-se

1. Moradia informal construída por um grupo de pessoas; elas se ajudam mutuamente para construir. 
também fatores individuais como história de vida, condições físicas e mentais. O desempregado sem teto sai dos papéis consensualmente definidos pela sociedade; o emprego tem uma utilidade social e de valor moral que eles perdem e, ao não recuperá-las, por meio de um emprego formal, saem da sociedade convencional para entrar na vida da rua. Muitos indivíduos se recusam a voltar às suas cidades nativas sem dinheiro no bolso, o que quer dizer que para eles morar na rua é um ponto de transição ou passagem à formalidade laboral que lhes permita ora ser provedores para lares fora da cidade, ora voltar com algum ganho (SAEKO / SANTOS, 2006, p. 150 / VIEIRA / BEZERRA / ROSA, 1992, p. 24).

Perfil 3: O liberado. O terceiro perfil é constituído por indivíduos que estão à procura de liberdade e que apresentam uma ausência ou atenuação dos laços familiares. Para alguns, a rua é uma opção entre muitas, já que as rupturas ou perdas pessoais fazem com que eles procurem um lugar fora da sociedade convencional. As perdas pessoais se relacionam com emprego, família, pessoas amadas, entre outras. Nesse perfil, encontramos as pessoas que olham a rua como um destino idílico. Os relatos comunicam a ideia de que na rua eles podem encontrar a liberdade desejada, o que faz dela uma escolha pessoal. Por isso, muitos saem de casa e têm uma permanência longa na rua, embora outros, tendo um lar, prefiram a rua como opção voluntária de moradia por curtos períodos de tempo, pois ao final voltam a seus lares. Mesmo que muitos tenham perdido vínculos familiares, outros atribuem a sua permanência em certos territórios aos vínculos que ainda conservam. Ficar num logradouro da cidade ou na mesma cidade às vezes se atribui a um familiar ali residente, o que indica que alguns conseguem manter algum contato com parentes, mesmo que seja por 
períodos espaçados. Nesse terceiro perfil, encontramos os meninos de rua. As pesquisas assinalam que a maioria deles, ao contrário do que se acha, não são órfãos nem foram abandonados pela família. Esses meninos possuem parentes, e a maioria mantém o contato com eles. Isso indica que sair de casa para morar na rua foi uma escolha pessoal, reflexo de sua falta de concordância com as regras do núcleo familiar ou uma consequência de lares fragmentados, o que faz com que sair de casa seja a opção mais conveniente para eles. À medida que se desenvolve a cristalização da condição de rua, o indivíduo muda seu agir: "constatou-se que à proporção que aumenta o tempo de rua diminui a frequência dos contatos" com a família. Mais tarde, os contatos cessam, e o morador de rua passa a criar laços com a própria rua (VIEIRA / BEZERRA / ROSA, 1992, p. 72).

Pode adicionar-se a esse perfil aquele indivíduo que, mesmo que tenha sido morador de rua, ainda dorme no centro da cidade porque às vezes falta dinheiro para as passagens de ônibus. Pode incluir-se neste grupo os catadores de papel e coletores de lixo que por questões de trabalho não conseguem retornar a suas casas na periferia da cidade e preferem gastar o pouco dinheiro que têm em comida ou bebida; às vezes ficam para cuidar do material catado. Eles não têm medo na rua, pois para eles é um território conhecido; em certo sentido, são "livres" do temor à rua. Esse perfil alberga um contingente amplo de pessoas, pois ainda existem nas ruas alguns exemplos do nômade de inícios de século XX:

"The hobo who begins his career by breaking the local ties that bound him to his family and his neighborhood, has ended by breaking all other associations. (...) "He is not only a 'homeless man' but a man without a cause and without a country” (PARK, 1952, p. 94). 


\subsubsection{AS CONDIÇÕES DOS MORADORES DE RUA}

Hoje se sabe que, mesmo que pertençam a um dos três perfis ou que possuam traços de mais de um deles, os moradores de rua podem encontrar-se em duas condições: temporária ou crônica. A população que pertence a cada uma delas varia, pois o contexto econômico e social de cada cidade pode propiciar o aumento ou a diminuição de uma das duas. No primeiro censo realizado na cidade de São Paulo, os pesquisadores identificaram essas condições num continuum, pois, ao colocar como referência o tempo de rua, os indivíduos podem situar-se em uma das duas condições apresentadas nesta pesquisa. A condição temporária, independentemente do perfil, é a condição da população flutuante que ainda tem pouco tempo na rua; por isso, "(...) ainda acredita nas formas tradicionais e a elas se submete mesmo sob grande esforço". É conhecido como o recém-chegado à rua, aquele agente circunstancial da rua, já que às vezes alterna a rua com outras situações precárias de habitação. Alguns estudiosos negam que este indivíduo seja "um morador de rua", já que para estes morar na rua é um processo no qual se rompem todos os laços sociais (trabalho, família, instituições, etc.), para criar novos laços dentro dessa população (SAEKO / SANTOS, 2006, p. 151).

Nas primeiras aproximações teóricas do fenômeno de rua em São Paulo, no decênio de 1990, assinalavam-se nessas condições dois grupos de pessoas. Primeiro, aqueles que estavam na rua circunstancialmente; pode afirmar-se que esses indivíduos "ficam na rua" por desemprego súbito ou acontecimentos inevitáveis, por exemplo quando ficam sem recursos para pagar uma pensão e não conseguem vaga em um albergue. Segundo, aqueles que chegaram à rua recentemente, esses indivíduos "estão na rua"; 
entram e saem tão seguido que perdem o medo e começam a estabelecer relações com as outras pessoas na rua. Os pesquisadores da primeira contagem determinaram que esses dois grupos tinham em comum o fato da utilização da rua como abrigo ou moradia. O grupo de moradores de rua em condição temporária é constituído por trabalhadores, repelidos ou atraídos pelo mercado de trabalho dos grandes centros urbanos. Esse grupo também é constituído pelos imigrantes, a população latente; isso é muito comum no caso de São Paulo, pois é um dos centros de trabalho a que muitos trabalhadores rurais chegam à procura de mais oportunidades laborais. Encontram-se também como recém-chegados à rua núcleos familiares que, por ter pouco tempo na cidade, por não ter aonde ir ou por terem sido recém-despejados, moram na rua. Esses grupos se vêm em condições econômicas extremas que os levam à rua, mas procuram uma forma de sair da vida da rua o mais rápido possível. A inserção do indivíduo na vida da rua não é imediata; inicialmente, ele não tem todas as concepções da vida na rua, conserva os códigos sociais mais comuns. Nega a denominação de "morador de rua" inicialmente, pois acredita que é uma condição temporária; para diferenciar-se dos outros moradores, apresenta-se como trabalhador desempregado. Gradativamente se vai inserindo na vida da rua, passa a frequentar lugares de distribuição de comida gratuita e instituições assistenciais. A aprendizagem dos códigos e regras da vida na rua é um processo lento, ele vai conhecendo-os pouco a pouco. O primeiro contato com a assistência social, especificamente com os albergues (Ver página 136), apresenta a ideia da condição temporária, porém acha que é possível conseguir a estabilidade econômica que lhe permita sair dessa condição. Nessa primeira etapa, é experimentada uma grande vergonha, motivo por que o recém-chegado à rua 
esconde essa condição da sua família. Nessa etapa inicial, procuram-se entidades públicas e assitencialistas a fim de se acessarem os programas sociais de auxílio. As medidas assistenciais para esses grupos vão desde o pernoite nos albergues, encaminhamentos (do tipo do Centro de Terapia e Reabilitação Integrada Municipal - Cetrem) e em muitos casos até ao oferecimento de passagens de retorno à cidade de origem. Em se iniciando o percurso por diversos centros assistenciais, pouco a pouco, os moradores de rua recém-chegados vão familiarizando-se com a rede assistencial da cidade.

É importante assinalar que a mobilidade nesse contexto é comum: as pessoas entram e saem da condição de 'morador de rua'. Essa parte da população não tem estabilidade econômica, social ou mesmo psicológica, portanto há períodos em que não mora na rua e outros em que retorna a ela. O caráter flutuante dessa porção da população em situação de rua faz com que quantitativamente estejam ausentes dos censos. Entre 1995 e 2000, o tempo médio de permanência na rua era de um ano, o que indica que um dos fatores que levavam aos indivíduos a rua temporariamente era o desemprego. Ao conseguir a reinserção no mundo de trabalho, o indivíduo conseguia sair da rua. O trabalho assalariado representa para a população de rua a possibilidade de desenvolvimento, acesso a melhores condições de vida, felicidade e realização pessoal. É possível que esses indivíduos alternem morar na rua ou em outro lugar de residência, sejam pensões, sejam cortiços. Assinala-se também como uma condição cíclica, já que em alguns casos o indivíduo sai e volta à rua. É um ciclo que varia em relação ao tempo de permanência na rua, podendo ser de semanas a meses, tendo relação com a capacidade do indivíduo de reinserir-se na 
sociedade formal e de suas oportunidades no mercado de trabalho. Esses são casos particulares para os quais não existe uma norma ou padrão, mas podem classificar-se dentro da condição temporária. A perda do sonho de uma vida melhor ou da perspectiva de uma mudança da situação constitui o começo de uma série de desestruturações pessoais. É quando se abandona a ideia de uma vida digna e formal e se inicia uma outra etapa na rua.

A condição crônica se estabelece a partir de um certo tempo de permanência na rua. À medida que o indivíduo passa mais tempo na rua, passa a haver uma ruptura dos vínculos econômicos, sociais e culturais; o indivíduo submetido a essa condição sofre um processo de depauperamento físico e mental, seja pela má alimentação ou pela dependência de substâncias lícitas ou ilícitas. Essas condições físicas dificultam sua inserção no mercado laboral formal e o tempo na rua complica sua capacidade de manter relações pessoais ou familiares. Nesse contexto, a rua ganha importância para o indivíduo, pois se torna o espaço de moradia permanente. Entrar em uma condição crônica de rua implica uma ruptura com as formas socialmente aceitas de sobreviver, significa abandonar as formas de trabalho formais para adquirir outras. Os indivíduos iniciam um processo de exclusão do resto da sociedade e de inserção em um novo grupo, uma espécie de "organização de rua", em que esses novos membros acham referências de socialização. Neste grupo estão a pessoas que moram na rua há mais de cinco anos: "a questão do tempo de permanência na rua também merece destaque, já que parece ser uma situação que facilmente se torna 'crônica". Ao morar muito tempo na rua, eles constroem uma série de regras e conceitos próprios desse grupo, por conseguinte "os que estão há mais tempo nas ruas, os outsiders, procuram 
outros modos que demonstrem a autonomia com que geram a própria sobrevivência". (QUIROGA / RODRIGUEZ -org-, 2009, p. 87 / SAEKO / SANTOS, 2006, p. 151).

Esse grupo é constituído pela população estagnada, em sua maioria trabalhadores ativos, mas em ocupações irregulares. São considerados uma espécie de exército de reserva, pois, em tempos de alta produtividade, o mercado de trabalho ofereceIhes empregos formais, em sua maioria no setor industrial ou construtivo; fora desses períodos, eles sobrevivem por meio do trabalho informal. A condição de um morador de rua passa de temporária a crônica dentro de um período de 2 a 5 anos; esse período de permanência assinala uma cristalização da situação de rua. As estatísticas indicam que "quase a metade da população em situação de rua $(48,4 \%)$ está há mais de 2 anos dormindo na rua ou em albergue; cerca de 30\% está dormindo na rua há mais de 5 anos... (30,9\%)". A valiosa informação confirma o período de 2 a 5 anos. (QUIROGA / RODRIGUEZ -org-, 2009, p. 87, 91).

A aceitação da rua como modo de vida é mais rápida e comum para aqueles que nasceram na rua. As consequências da permanência na rua são palpáveis: "muitos no entanto acabam permanecendo mais tempo no desamparo e a situação de conviver com a rua e com as atividades marginais passa a ser então sua realidade, sua única possibilidade de sobrevivência" (SIMÕES, 1992, p. 19).

Para muitos, a situação crônica de cristalização da situação de rua é de difícil reversão, pois quanto maior o tempo na rua, maior a dificuldade de se restabelecerem todos os laços anteriores: trabalho, moradia formal e família. As condições próprias da vida de rua tais como pobreza, desemprego, doenças, instabilidade econômica e social fazem 
deles um alvo de repúdio e discriminação. Gera-se um quadro de isolamento social, que produz tanto dificuldades na reinserção quanto um afastamento severo da sociedade em geral. Os moradores de rua, à medida que continuam nesse modo de vida, integram-se mais e mais à sua nova vida, afastando-se mais e mais do resto do mundo. Por isso pode afirmar-se que é um processo de perdas contínuas, até o ponto de se ficar só com a vida de rua, momento no qual se perde o compasso interno, fundamental para a vida de qualquer indivíduo, o que leva a muitos à loucura. Os censos têm revelado até agora o caráter heterogêneo da população de rua; mesmo que hoje haja mais estudos sobre essa população, alguns dos preconceitos se mantêm: "é importante dizer que os resultados encontrados na pesquisa contrariam uma visão corrente sobre a população de rua, que a representa". Mesmo que hoje existam perfis que descrevam a maioria da população de rua, os estudos em todo o país revelam o caráter flutuante, qualitativa e quantitativamente, dessa população. Para a maioria dos observadores, os moradores de rua são vagabundos, malandros, vadios, maloqueiros ou coitados; existem muitos estereótipos que distam muito da realidade nas ruas de São Paulo (VIEIRA / BEZERRA / ROSA, 1992, p. 63).

Em relação ao preconceito de que a maioria é viciado, sabemos hoje que os dependentes de substâncias ilícitas constituem uma terceira parte da população. Os dados dos dependentes de substâncias lícitas ou ilícitas na década de 90 indicam que cerca de 31\% já esteve internado em alguma instituição, principalmente hospitais psiquiátricos e orfanatos. A população que pertence ao Perfil 1 (Ver página 38) tem uma longa história de dependência ou de problemas psicológicos. A sua inserção na rua parece seguir o curso natural da vida de dependência. Existem dados contrários 
ao preconceito de que todos os moradores têm baixa escolaridade; na década de 90, as pesquisas apresentam diversos graus de escolarização dessa população: "a proporção de indivíduos alfabetizados é alta, 89\% com escolaridade em nível de $1^{0}$ grau". As contagens também assinalaram a presença na rua de um pequeno grupo de pessoas com formação universitária, ao parecer, é um fenômeno comum em muitos países desenvolvidos. A mínima quantidade de pessoas na população em situação de rua com escolaridade nenhuma se mantém, 12,2\% homens e 17,6\% mulheres, a diferencia dos primeiros resultados das pesquisas é que a porcentagem da população alfabetizada se distribui em diferentes graus de escolaridade (SIMÕES, 1992, p. 35 / QUIROGA / RODRIGUEZ -org-, 2009, p. 101 / PMSP, 2012, p. 14).

A ideia de que a maioria dos moradores de rua procedem do nordeste é esclarecida pelas pesquisas, já que elas apontam para uma variação do estado de origem. Na década de 90 , os pesquisadores descobrem que: "28\% são naturais do Estado de São Paulo, dos quais $14 \%$ da Capital" e "46\% dos pesquisados nasceu na região Sudeste", o que indica que a ideia de que a maioria dos moradores de rua seja do Nordeste é desprovida de fundamento (SIMÕES, 1992, p. 37).

Na década de 90, 50\% do povo de rua é constituído de indivíduos de cor branca, 30\% de pardos e $20 \%$ de negros; isso indica que nem sempre a maioria da população em situação de rua pertence à raça negra, como ocorre na década de 2000 . Ou seja, a população de rua muda conforme as circunstâncias de cada cidade e de cada tempo histórico. Na cidade de São Paulo, por exemplo, a população de rua constitui-se em sua maioria por pessoas economicamente ativas, "a população é considerada jovem 
e em idade produtiva, pois $70 \%$ possui menos de 40 anos". Hoje se sabe que uma mudança do contexto econômico local poderia mudar a predominância desse grupo na população de rua. Isso reforça a importância do contexto econômico da cidade onde se observe o fenômeno de rua (SIMÕES, 1992, p. 35).

Em relação ao preconceito de que todo morador de rua é desempregado, na mesma década, verifica-se que $85 \%$ realizam trabalho irregular na forma de bicos; isso indica a relação dos moradores de rua com o setor da economia informal. Também se assinala que eles são economicamente ativos, mesmo que os trabalhos que desenvolvam não sejam percebidos. Uma das deduções mais importantes dos estudiosos é:

"Qualquer cidadão pode acabar na rua. O indivíduo bem vestido que hoje passa e olha com desprezo para um mendigo, pode amanhã ser um deles" (SIMÕES, 1992, p. 29).

Um dos preconceitos mais comuns relacionados com o povo de rua é a preguiça, que já foi caracterizada, em outras épocas, como pecado e como crime. Muitos países estabeleceram a "Lei de Vadiagem", uma maneira de combater a mendicância e de forçar os "vadios" a trabalhos pesados com baixa ou nenhuma remuneração. Nem todos os moradores de rua são vistos da mesma maneira, mas a predominância dos homens dentro do povo de rua e a noção infundada de que em sua maioria são viciados, com aversão ao trabalho formal, faz que as famílias ou crianças em situação de rua sejam tratadas com mais consideração por parte das organizações sociais do que da população em geral. O morador de rua carrega sobre si a avaliação de sua condição criada pela sociedade em geral: o fracassado. 
O preconceito do caído constitui uma etiqueta assumida, e o indivíduo logo passa à autoculpabilidade pela situação em que está. Mesmo que tenham permanência na rua, eles referem-se a si mesmos como trabalhadores desempregados (ex-pedreiro, ex-peão, etc.), como uma maneira de conservar parte da identidade aceita pela sociedade e evitar identificar-se com o resto do povo de rua. Repetidas vezes fazem e perdem os documentos; fazer os documentos é um ritual com o qual se tentam reinserir na sociedade formal.

\subsection{A REINSERÇÃO NA SOCIEDADE}

Ao entender as duas condições enfrentadas pelos moradores de rua, a temporária e a crônica, é lógico apontar que aqueles na situação temporária são os que conseguirão uma reinserção social mais rápida. Parece que, quanto maior for o tempo na rua, menores serão as probabilidades de reinserção. As políticas assistenciais hoje não prestam atenção ao morador de rua que tem menos probabilidades de uma reintegração social e profissional. Assinala-se, em Saeko e Santos, que tanto o trabalho de assistência social quanto as pesquisas indicam que "oferecer uma moradia ou o vislumbre de um trabalho não são garantia de efetiva reinserção". A reintegração à sociedade implica um trabalho integral, acompanhando o indivíduo em diversas etapas nas quais ele vai deixando para trás as concepções da rua, apropriadas no percurso de sua vida de rua, e adicionando novos conceitos e formas de relacionar-se (SAEKO / SANTOS, 2006, p. 162). 
Gusmão afirma que esse grupo de pessoas produz um aporte valioso para a sociedade, essa contribuição representando parte do patrimônio urbano imaterial: "vem a ser o grupo responsável pelo desenvolvimento de aspectos peculiares e notáveis da cultura material urbana". As histórias dos moradores de rua se entrelaçam com o meio urbano, pensar na rua é pensar na cidade (GUSMÃO, 2004, p. 18-19).

Outras pesquisas mostram que uma parte da população possui a esperança de sair de rua, isso por meio de um trabalho formal e da ajuda de outros. Nem todos os moradores de rua compartilham desse sonho, embora alguns deles planejem concretizar esse sonho por meio de alguma esfera pública. A abordagem da problemática da população com um olhar psicológico também mostra a sua autoafirmação como honestos, queixam-se das autoridades policiais e, mesmo que eventualmente consumam drogas, conseguem identificar os viciados e excluí-los (SERRANO, 2004, p. 23).

Hoje, as pesquisas constroem uma imagem não de vítimas mas de agentes ativos. Os moradores de rua criam, constroem, transformam e resgatam. Seu papel ativo na sociedade é representativo das condições econômicas e sociais da cidade, mesmo que seja uma rede informal e não reconhecida pelas outras parcelas da população. Construir uma nova identidade coletiva tem sido um dos passos seguidos pelos moradores de rua, seja como povo da rua ou sofredores de rua. As primeiras iniciativas de empreendimentos solidários no Brasil relacionados com os moradores de rua surgem na década de 80, incorporando atividades da economia social e representando uma reação ante a crise econômica que se iniciara na década anterior. As iniciativas contemplavam, além do econômico, as esferas social, política e solidária. 
A noção de solidariedade que se tem encontrado em evidência no Brasil a partir da década de 90 obtém grande impulso com a Constituição de 1988. Nesse momento, o país enfrentava um agravamento das desigualdades sociais; a resposta às medidas econômicas neoliberais foi gerar um Estado-Providência (KEMP, 2008, p. 30).

Inicialmente essas iniciativas se relacionavam com a catação de lixo e eram dispersas, mas, ao continuar seu desenvolvimento na sociedade brasileira, esses esforços isolados tornam-se redes que mobilizam ações e recursos de toda espécie. É um processo gradativo, no qual os frutos da atividade desenvolvida são inicialmente para a sobrevivência do indivíduo; à medida que o trabalho continua, surge a necessidade de organização das tarefas e a procura de melhores ofertas, portanto, com as ações adicionais de gestão, essa atividade transforma-se em um empreendimento. Ante as consequências da crise econômica, o associativismo econômico parece o passo naturalmente a ser seguido na procura do desenvolvimento dos empreendimentos solidários; os moradores de rua apresentam, de per si, a tendência natural de agruparse, portanto, ao procurarem a reinserção na sociedade, dirigiram-se a grupos afins. O associativismo econômico apresenta-se como uma resposta imediata às demandas sociais urgentes das pessoas que, relegadas ao desemprego e às condições precárias do trabalho informal, procuraram brechas para inserir-se no mercado formal de trabalho. No momento em que o grupo trabalha sistemática e continuamente, estabelecemse normas de trabalho, responsabilidades e benefícios para os associados; nesse ponto se formaliza o grupo como uma associação. Usualmente existe um rodízio das funções, o que permite que todos os membros trabalhem em distintas tarefas para que possam desenvolver diferentes habilidades. 
Precisa-se de ações adicionais às simples tarefas de coleta e classificação de lixo; a gestão é a chave necessária para transformar a coleta de lixo em um empreendimento solidário. Inicia-se então a procura de espaços para o trabalho coletivo, dos melhores preços, da maquinaria para facilitar o empacotamento, da organização da distribuição de carros, entre outras.

O empreendimento solidário constitui um contrato de obrigação mútua e reciprocidade, os indivíduos que constituem o grupo estão comprometidos entre si. Entre as obrigações adicionais ao trabalho adquiridas pelos moradores de rua na associação, estão: a sobriedade, o cumprimento dos regulamentos de trânsito com os carrinhos, a colaboração na limpeza do espaço do trabalho, o cumprimento com uma cota mínima semanal, etc. As regras são discutidas e aceitas em consenso, por isso as normas disciplinares são aceitas facilmente pelos integrantes mais antigos; os novos integrantes do grupo, porém, enfrentam dificuldade de assumi-las. O conceito da lei do mais forte é deixado de lado e se desenvolve um controle horizontal onde os membros discutem as ações a seguir. A convivência em grupo requer negociação, pois é provável que seus integrantes venham de realidades muito distintas (imigração, desemprego, infortúnios, etc.) e que a associação seja a única causa comum entre eles. Esse aspecto psicológico do empreendimento solidário é contínuo e evolutivo, pois à medida que o empreendimento cresce, as demandas e negociações são mais complexas. A associação enfrenta profundos desafios que antecedem sua constituição, mas após sua consolidação os integrantes compartilham as lutas, vitorias e derrotas, e esse processo solidifica o grupo. O empreendimento solidário faz com que os indivíduos do grupo reconstruam tanto as identidades socioprofissionais, quanto os laços sociais. 
Por meio desses grupos, os indivíduos recuperam o pertencimento social, a participação efetiva, o sentido de coletividade e a possibilidade de gerar novas formas de regulação do laço social. O objetivo é recuperar todos os itens que perderam à medida que adentraram a vida de rua. Exemplos desses empreendimentos são a Comunidade dos Sofredores de Rua e a Cooperativa dos Catadores Autônomos de Papel, Aparas e Materiais Reaproveitáveis (Coopamare). A primeira foi constituída formalmente em 1983, momento no qual havia um Centro Comunitário no Glicério, espaço de encontro e trabalho para esse grupo de indivíduos. Dois anos depois, porém, na administração do Prefeito Jânio Quadros (1985) dificultou-se a continuação de sua iniciativa. Esse tipo de empreendimento se inicia com a constituição de um fundo comum para as despesas do coletivo, construindo-se a primeira carroça e organizando o trabalho de todos. Ao se constituírem como grupo organizado, são fortalecidos na luta pelo direito de trabalhar com o lixo.

Os moradores de rua também se têm agrupado com fins políticos comuns, o ativismo político e o começo da reconstrução da cidadania. Registram-se no Brasil diversas tentativas de organizações relacionadas com moradores de rua que começaram na década de 1960, mas foi em setembro de 2005, durante o $4^{\circ}$ Festival Lixo e Cidadania, que foi lançado o Movimento Nacional da População de Rua (MNPR). Os crimes cometidos contra a população de rua, especificamente a Chacina da Praça da Sé, em que sete moradores de rua foram vitimados, detonaram a formalização de uma frente comum de associativismo político entre o povo de rua. Um dos ganhos mais significativos do movimento foi a inclusão de um representante do MNPR no Conselho Nacional de Assistência Social. 
Outro dos avanços do associativismo político foi a participação do MNPR na Pesquisa Nacional de Moradores de Rua (2009); no mesmo ano, o Decreto Presidencial no 7053 instituiu a Política Nacional para a População em Situação de Rua e o Comitê Intersetorial de Acompanhamento e Monitoramento da Política Nacional (CIAMPRUA). O resultado de anos de luta foi uma série de eventos, seminários e fóruns que cumpririam dois propósitos, tanto fechar um ciclo em que a luta deixou resultados palpáveis, quanto começar um novo período em que os propósitos deveriam ser repensados, já que o fenômeno de rua muda constantemente e precisa-se de novas iniciativas a fim de atingir a problemática a fundo (MNPR, 2010, p. 30, 31).

Além dos benefícios em questão legal, procuram uma solução para a problemática da moradia para as pessoas que estão na linha da miséria. Exemplos disso são o Movimento da Rua para a Terra (MRT) e o Movimento dos Sem Terra(MST). Registramse casos de pessoas que conseguem sair da rua por essa via. A dificuldade dessas ações está no fato de que deve existir tanto um reconhecimento dos moradores de rua como cidadãos, quanto o reconhecimento do resto da sociedade, pois sem esses componentes o movimento não tem relevância. Precisamente por isso o resgate da cidadania por meio do trabalho digno é um dos primeiros objetivos do associativismo político do povo de rua, seguido pela luta por um salário suficiente para o sustento dos moradores de rua, deixando a moradia digna e o acesso à saúde como últimos objetivos. As associações solidárias constituíram um novo tipo de organização social para se organizar e agir na sociedade brasileira. A sua legitimação chegou após um largo processo de negociações com as autoridades e os atores sociais; seu resultado foi a rearticulação das relações dos moradores de rua com a sociedade nas esferas 
social, econômica e política. O papel do setor público nesse contexto é o de gerar políticas públicas que tenham como objetivo facilitar a transformação dos moradores de rua, de pessoas excluídas, em atores sociais ativos. A demanda mais imediata é o sustento, mas, à medida que se age na esfera pública, estabelecem-se relações com as autoridades locais e a sociedade civil. As autoridades, ao reconhecerem o trabalho dos moradores de rua por meio das Associações Solidárias, paralelamente regulam o laço social, pois lideram de algum modo a aceitação do público em geral. Nos processos de reinserção social, destaca-se o papel das Organizações Não Governamentais, conhecidas como ONGs. O exemplo mais representativo disso é a Pastoral de Rua da Arquidiocese em Belo Horizonte, que primeiro identificou uma atividade econômica já desenvolvida pelos moradores de rua. A Pastoral de Rua procurou trabalhar com os grupos já estabelecidos, isso constituiu uma valorização e reconhecimento de seu trabalho de manter a cidade limpa. A entidade com sede em Belo Horizonte abriu um espaço para o diálogo, o que fez com que os moradores de rua recobrassem o sentido da vida na sociedade formal. Há falta de apoio logístico e material que assegure uma permanência nas novas condições. Uma das fraquezas dos programas ou ações de reinserção é o fato de que a maioria solicita um endereço fixo. Esse requisito exclui os moradores de rua (MONTES, 1995, p. 195).

Há também o discurso higienizador em que se aborda a reinserção como uma recuperação e reabilitação física, social e moral. Nessa abordagem, tenta-se tirar o indivíduo de um patamar de doença. No discurso moralizador, tenta-se regenerar o individuo; nele se relaciona o processo de reinserção com o conceito de trabalho. 


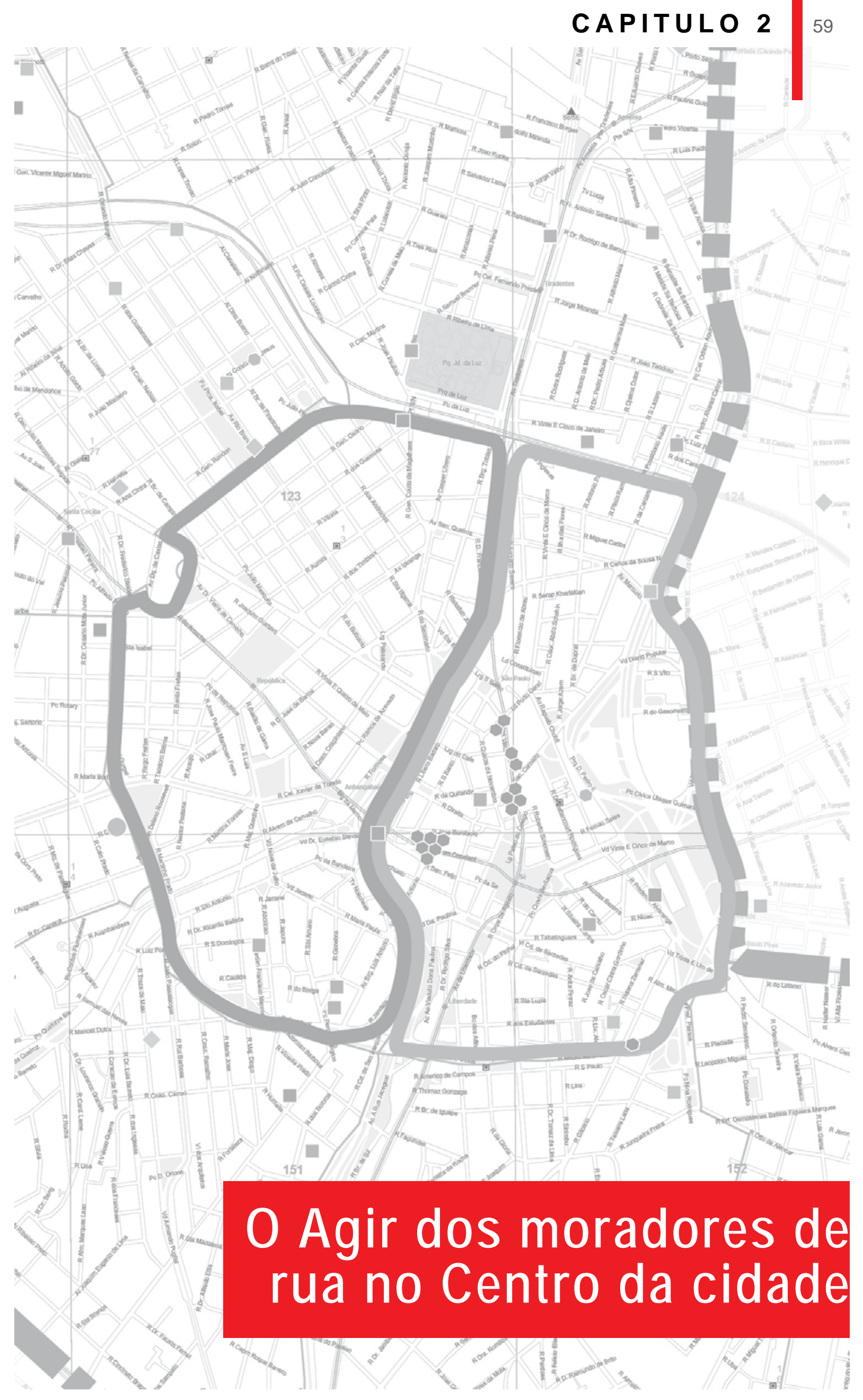




\subsection{VIVER NAS RUAS DE SÃO PAULO}

O termo "morador de rua" coloca o contexto em que se desenvolvem as relações sociais dessa população. Embora o espaço ocupado seja de domínio público, ao ser o espaço de moradia da população de rua, torna-se privado. O povo de rua tem outro olhar da cidade, atribuindo novas funções aos espaços; esse é um processo gradativo no qual se privatiza o que é público, um fato conflitivo para os outros usuários dos espaços da cidade. Na rua se cria um modo de vida que inclui comer, dormir e trabalhar; novos hábitos são incorporados ao modo de vida e novos códigos são adicionados. Por isso, os atos usualmente reservados aos espaços privados tornamse públicos, o que provoca a rejeição de muitos usuários da cidade. Em questão de gênero, sabe-se que esse "grupo sem residência fixa é constituído em sua grande maioria (92\%) por indivíduos do sexo masculino vivendo sós". Na população de rua existem poucos grupos integrados só por mulheres, pois, por seu caráter vulnerável, as mulheres em condição de rua normalmente fazem parte de um casal ou gravitam em torno dos grupos dos quais podem receber proteção. As crianças, por sua vez, agrupam-se formando temíveis quadrilhas. Esses grupos de crianças são temidos até pelos adultos de rua, que evitam interferir nos territórios das crianças de rua organizadas (QUIROGA / RODRIGUEZ -org-, 2009, p. 149 / SIMÕES, 1992, p. 35).

As diferentes pesquisas com tema dos moradores de rua identificam que eles desenvolvem padrões de comportamento consistentes; seu agir se apoia em artefatos e elementos cognitivos que eles possuem, caracterizando-se assim um estilo de vida vigente desde o início dos estudos até hoje. Considera-se por isso a vida nas ruas como 
uma subcultura limitada, pois conota uma mistura bem específica de comportamentos que os distingue como grupo; seus integrantes compartilham traços, dilemas comuns e objetivos - isso motiva sua associação (SNOW / ANDERSON, 1998, p. 75).

Parte importante da vida na rua é relacionar-se em grupos; registra-se a existência de grupos constituídos por membros com valores ou objetivos afins; são uma espécie de rede de apoio, sendo um dos principais requerimentos a coesão dos membros. Conhecidos na rua como "malocas", os grupos representam a possibilidade de melhores condições em relação à subsistência e à segurança. Cada grupo tem normas próprias, exerce um grau de controle e delega funções em concordância com os fins do grupo, constituindo uma espécie de família alternativa. São poucos os moradores de rua que vivem isolados; mesmo que alguns não convivam o tempo todo em grupos, reúnem-se para fins laborais ou para segurança por períodos curtos durante o dia ou a noite. A palavra-chave para esse tipo de dinâmica é a solidariedade, pois os recursos limitados são compartilhados ou até priorizados nos casos onde existe a vulnerabilidade de um dos membros, tal é o caso de doentes, idosos e crianças. Um dos exemplos mais claros disso é o trato dos bebês dentro dos grupos; essa nova adição à dinâmica é respeitada e priorizada, todos os membros do grupo colaboram e se solidarizam com o novo membro. O número de integrantes dos grupos varia de 5 a 50; na maioria dos pontos de pernoite pesquisados se encontraram grupos; aproximadamente $10 \%$ dos grupos encontrados se constituíam por um número acima de 30 integrantes. Mesmo que variem em sua constituição, os grupos têm muitos objetivos comuns, desde manter a segurança comum até compartilhar alimentos ou substâncias ilícitas. Os grupos grandes usualmente se relacionam com fins laborais; 
alguns se localizam perto de empresas jornalísticas para carregar pacotes ou distribuir jornais. Existem grupos formados para uma função específica, por exemplo existem grupos que se reúnem só para pernoitar. O desenvolvimento da convivência em grupos indica a cristalização da condição de rua; o indivíduo aceita que pertence a um grupo que está fora da sociedade em geral e age em concordância com a lei do grupo. O indivíduo assume no grupo uma nova identidade social; é um momento de transição, pois, após aceitar a condição de rua, ele enfrenta discriminação por parte de outros segmentos sociais. Criam-se estruturas diferentes daquelas a que se ligam os indivíduos domiciliados, visto que a noção convencional de lar não é vigente nesse contexto.

Geram-se códigos próprios, volta-se ao passado e utiliza-se a troca como sistema de compra e venda. É um sistema em que a maioria dos bens materiais são compartilhados em partes iguais ou de acordo com a hierarquia. Os intercâmbios de bens materiais (bebida alcoólica, cigarros, comida) ou de experiências afetivas dependem das regras do grupo; existem também sanções para comportamentos que destoem das regras estabelecidas, tendo por finalidade regular as relações dentro do grupo. As relações desenvolvem-se com uma ordem hierárquica, o que quer dizer que existe uma liderança aceita por todos os membros, seja pela idade, pela força física, pelo tempo de permanência ou pela função que o líder exerce no grupo. Cada grupo tem uma regra própria para a aceitação de novos integrantes; é possível que o líder decida ou que seja um consenso entre os integrantes mais antigos. Às vezes não existe uma liderança individual, mas uma espécie de conselho que compartilha as responsabilidades. 
A convivência de moradores de rua em grupos não é uma dinâmica nova na cidade de São Paulo; nas primeiras pesquisas desenvolvidas na década de 90, há registros da constituição e desintegração de grupos; "em Santa Cecília o grupo da Tia Teresa se manteve organizado até a sua morte; o da Fazendinha sobreviveu como grupo até o momento em que houve briga de liderança" (VIEIRA / BEZERRA / ROSA, 1992, p. 59).

A fala identitária é indicada pelas autodesignações e autoatribuições que expressam a concepção real ou desejada do ator em relação a outros e ao contexto situacional. Parte do processo de inserção na vida de rua é a aprendizagem desses códigos de falar e agir que comunicam intenções aos outros moradores de rua (SNOW I ANDERSON, 1998, p. 82).

O assuntos falados também são importantes, pois assinalam o estágio em que os moradores de rua se encontram: os recém-chegados, por exemplo, falam muito dos planos para sair da rua; os que padecem da condição crônica não mencionam o assunto em sua fala. Os padrões e orientações adaptativas que desenvolveram os diferenciam suficientemente para determinar a quantidade de tempo que eles têm na rua. Uma das atividades mais comuns dos moradores de rua é mergulhar no lixo de estabelecimentos comerciais, prédios de moradia, restaurantes e feiras livres para conseguirem alguns alimentos. Outra das práticas consiste em pedir pratos aos restaurantes ou a seus usuários. Estima-se que " $80 \%$ fazem menos que uma refeição por dia, sendo que 20\% não se alimentam diariamente" (QUIROGA / RODRIGUEZ -org-, 2009, p. 149). 
Antigamente davam-se pratos de comida aos mendigos que passavam de casa em casa, batendo nas portas. No caso de não haver comida, costumava-se pedir-Ihes “ perdão”, por não ter o que lhes dar. Esse costume mantém-se nas comunidades pequenas, mas não em grandes centros como São Paulo. Existem locais de distribuição gratuita de comida ("bocas de rango") em espaços públicos da área central (praças, viadutos e parques), feita por instituições assistenciais, na maioria das vezes nos fins de semana. Caso contem com recursos, eles procuram restaurantes populares que ofereçam refeições por preços baixos.

Parece que a escolha de frequentar um determinado ponto de distribuição de comida, em uma das dinâmicas já mencionadas, depende da organização do cotidiano de cada individuo em condição de rua. A rotina individual determina os horários e locais mais frequentados, por isso existe uma grande afinidade entre os assíduos desses pontos de distribuição de alimentos.

A maioria da população de rua dorme de dia e age à noite. Fazem isso a fim de salvaguardar tanto a segurança própria quanto os poucos pertences pessoais. $\mathrm{O}$ descanso não é longo, pois é interrompido por períodos de vigília em que eles têm que enfrentar os perigos da rua: ladrões e/ou estupradores. Um do seus bens mais valiosos é o "galo", uma sacola com pertences essenciais para sua sobrevivência na rua. Entre os riscos nas ruas, há "batida policial fazendo detenções ou expulsando-os do local em que estão acomodados; menores de rua e pivetes que passam em bando fazendo espancamentos e muitas outras violências". Os moradores de rua sofrem violência por parte de seus iguais; sendo o mundo da rua tão diverso, é formado por 
pessoas com diferentes fins (SIMÕES, 1992, p. 27).

Sabe-se que pernoitar em praças é muito arriscado para aqueles que vivem sozinhos. O fator segurança é primordial para estes moradores de rua, por isso eles escolhem lugares com grande movimentação de pedestres para dormir ou pernoitar. Os moradores de rua que não têm grupo pernoitam em avenidas concorridas como a São João ou a Ipiranga. Os grupos têm uma atuação diferente daquela dos indivíduos sós, pois, ao moverem-se nas ruas como matilha, possuem mais força física e enfrentam menos perigos. Dormir em grupo representa segurança, e o número de integrantes no grupo importa, pois haver mais integrantes implica mais segurança. Eles escolhem os calçadões de pedestres como São Bento e Barão de Itapetininga ou "bancos da Praça da República e na Praça Júlio Prestes". Mesmo assim se mantêm perto dos guardas de segurança das lojas nesses calçadões para ter algum tipo de auxilio em situações de risco (SIMÕES, 1992, p. 27).

À medida que o indivíduo se adapta à vida da rua, os pesquisadores indicam que se desenvolve a procura de grupos constituídos por mais moradores de rua; os grupos proveem proteção em relação a possíveis denúncias da vizinhança que os tornem alvos das autoridades, pois, como grupo, os moradores de rua são mais temidos. $\mathrm{Na}$ década de 90, baseados em observações empíricas, as primeiras pesquisas se desenvolveram nos lugares da cidade onde se identificavam concentrações de moradores de rua. Registraram-se os logradouros em que os moradores de rua costumavam pernoitar: praças, calçadas, marquises, jardins, baixos de viadutos. Áreas degradadas ou abandonadas também são alvo de invasões com fins de reunião 
ou pernoite: galpões, prédios abandonados, edificações em ruína, terrenos baldios, mocós², tumbas de cemitérios e carcaças de veículos. Por último encontramos as pensões ou albergues; estas escolhas, menos comuns. Esses logradouros não só são ocupados, mas em alguns casos são transformados, essa é uma das contribuições dos moradores de rua, pois eles conseguem mudar as cidades. A permanência na rua faz com que os moradores de rua acumulem pertences e prevejam eventualidades (nestes casos, a experiência da vida na rua mostra seus frutos). Eles transformam os espaços públicos em locais de moradia; a necessidade de refúgio faz com que eles tirem proveito dos espaços residuais ou irregulares da cidade, tais como esquinas ou buracos. Alguns espaços se tornam de convívio ou trabalho permanente. A partir disso, cria-se uma cidade informal, que funciona como uma rede abaixo da cidade formal, com seus caminhos percorridos pelos moradores de rua. Eles obtêm os materiais para construir seus refúgios no lixo: "[a pesquisa] constatou a presença extraordinária de todos os tipos de embalagens, com as quais os moradores de rua criam uma variedade de soluções para exercer as funções da vida doméstica no espaço público". Os materiais recebem um novo significado, pois os objetos achados no lixo tornam-se materiais para construir refúgios ou utensílios do lar. A finalidade dos objetos muda, após um processo criativo, para um fim diferente do concebido originalmente. O que é jogado no lixo e considerando sem valor é resgatado pelos moradores de rua e transformado (SANTOS, 2005, p. 14).

As pesquisas relacionadas com a construção dos refúgios assinalam que cada cidade produz diferentes tipos de materiais descartados; atualmente as áreas centrais das

2. Propriedades abandonadas; na maioria dos casos são imóveis depredados e pichados. 
cidades concentram grandes quantidades de descarte de materiais utilizados pelos moradores de rua. Desenvolveu-se uma estética do reciclado, pois o povo da rua mergulha no lixo procurando certos materiais e cores, o que se torna parte da nova cultura: a partir do desperdício, atribuem-se novos significados aos objetos (PEREIRA I SANTOS, 1998, p. 760).

Adiciona-se a isso o fato de que cada morador de rua imprime sua criatividade e gosto pessoal na construção dos refúgios, eles são constituídos como espaços importantes, quase sagrados. Produto do design espontâneo, as moradias temporárias dos moradores de rua apresentam qualidades únicas: “(..) construir abrigos frágeis, movidos pela necessidade, fez com que os desabrigados transformassem o conceito e a dinâmica das cidades". Na cidade de São Paulo, no inverno, é comum observaremse estruturas constituídas por plástico e papelão (SANTOS, 2005, p. 13).

Sabe-se pelas pesquisas que um dos materiais mais utilizados é o plástico de cor azul, seguido pelas cores branco e verde, não só em São Paulo, mas também em Los Angeles e Tóquio; não deve deixar-se de lado o papelão e alguns têxteis. Um dos objetos esquisitos achados nesses refúgios são brinquedos (bonecas ou ursinhos de pelúcia), plantas de plástico e outros objetos que constituam lembranças de um lar, assim como móveis e aparelhos resgatados do lixo (SANTOS, 2005, p. 4).

A capacidade de adaptação dos moradores de rua a seu entorno é surpreendente; os refúgios utilizados são diversos, vão desde carroças fabricadas por eles, passando por estruturas improvisadas com materiais descartados, por barracas ou tendas, 
até os ambientes mais equipados instalados embaixo de viadutos ou pontes. Os pesquisadores registram o desejo de alguns moradores de rua de criar um espaço permanente de moradia, mesmo que seja precário (RABINOVICH/TASCHNER, 1998, p. 38).

Os recém-chegados à rua pernoitam expostos (Ver página 43); na década de 90, "em $30 \%$ dos lugares pesquisados encontraram-se pessoas dormindo ao relento (105) sem nenhum tipo de cobertura". Em geral, isso indica uma condição de recém-chegado ou temporária (VIEIRA / BEZERRA / ROSA, 1992, p. 54-55).

Em relação à moradia, RABINOVICH/TASCHNER (1998) identificam tanto as formas de moradia, quanto os indivíduos que as desenvolvem; estes vão do errático ao fixo; os autores os classificam em: 1) Selvagens; 2) Nômades; 3) Cavernas e 4) Assentados. A população de rua classificada como "selvagem" não procura um lugar fixo, sempre se desloca de um pontoao outro da cidade. Consideram-seselvagenspormoraremna"selva de concreto"; adotam essa denominação em parte por terem abandonado a sociedade formal. É um modo de vida errático, no qual não se procura uma rede para subsistir mas podem associar-se com outros indivíduos para propósitos comuns como roubos ou consumo de drogas. Os moradores de rua considerados como "nômades" constroem seus refúgios sob estruturas formais, utilizando papelão, caixotes, plástico e outros materiais. São construções frágeis que utilizam parte das construções formais da cidade, tal é o caso das paredes dos viadutos. Seu espaço está em constante transformação, pois não se tem um ingresso fixo e suas circunstâncias podem exigir mudanças na estrutura, por exemplo por chuva ou frio. Às vezes nessas circunstâncias existe a 
tendência de agrupar-se com a clara presença de um líder. Os classificados como "cavernas" aproveitam espaços residuais constituídos por estruturas formais, que são tomados e aproveitados como refúgio. Um dos melhores exemplos são os vazios nas estruturas dos viadutos ou os prédios abandonados. Os roedores, insetos e animais nesses espaços constituem dificuldades para os moradores de rua, a falta de ventilação e insolação aumenta a sua insalubridade. Nesses espaços, os moradores de rua ficam isolados do resto da sociedade; em sua maioria, as "cavernas" são habitadas por famílias ou grupos organizados. A precariedade e a sua contravenção à lei podem provocar que sejam despejados desses espaços pelas autoridades locais.

Na classificação dos "assentados" se incluem aqueles moradores de rua que procuram espaços fixos na cidade e conseguem transformá-los em moradias em que predominam condições precárias e informais. Essas morarias possuem portas, cortinas, cozinhas e outros elementos básicos para sua subsistência. Os moradores de rua assentados acumulam objetos a fim de consolidar seu lar improvisado; possuem parceiros, bichos de estimação e outros elementos que expressam o desejo de uma vida formal. Usualmente esses moradores possuem uma estratégia de subsistência contínua. Podem considerar-se em conjunto como assentamentos precários semelhantes às favelas, cujo endereço pode ser um viaduto ou um comércio da área. Se conseguem serviços, são irregulares ou precários, obtidos mediante conexões ilegais com a rede pública; a luz é usualmente roubada da rede pública, e a água é procurada nos postos de gasolina ou em outros comércios. Não existem espaços definidos para as funções comuns de um lar dentro dessas moradias precáriase, mesmo que estejam organizados, estão em constante transformação para adaptarem-se às circunstâncias climáticas. 
A população de rua frequenta os serviços públicos, especificamente os postos de saúde e hospitais. Na década de 1990, registraram-se, nos centros de assistência social, atendimentos em sua maioria de casos de alcoolismo crônico, seguidos por senilidade e pneumonia (SALVADOR, 1995, p. 153).

Os atendentes dos serviços de assistência social observaram que a maioria dos moradores de rua que procuram atendimento estão na faixa dos 50 anos; os casos usualmente são terminais, o que quer dizer que o povo de rua procura assistência médica em caso de doenças avançadas. Outra observação importante é o fato de que os atendidos recusam procurar contato com familiares, mesmo que estejam em estado terminal. Nos últimos anos surgiram registros de idosos nas ruas, casos de pessoas mais velhas que ficam em condição de rua, sem família ou recursos para sobreviver nessas condições precárias. Aparentemente por não serem economicamente produtivos, o núcleo familiar os expulsa, e a rua se torna a única opção para sua sobrevivência.

Os problemas mentais são as incidências mais registradas em moradores de rua: casos de pessoas que possuem alguma doença mental sem ter consciência disso, seja porque não foram diagnosticados, seja porque a família nunca lhes informou da doença. Ao serem entrevistados, muitos dos moradores de rua afirmam terem sido internados em alguma instituição, principalmente Hospitais Psiquiátricos, Fundação Estadual para o Bem Estar do Menor (FEBEM) e Orfanatos. As outras incidências registradas têm relação com a dependência de substâncias, especificamente o álcool. Registram-se cirroses, pancreatite, hepatite alcoólica, câncer de fígado, varizes no 
esôfago, etc. Os problemas respiratórios são comuns na temporada de inverno entre a população de rua; nas listagens das doenças registradas estão também os problemas cardiovasculares e ortopédicos. São também comuns entre a população de rua as doenças da pele provocadas por parasitas.

\subsubsection{AS ESTRATÉGIAS DE SUBSISTÊNCIA E AS FUNÇÕES URBANAS}

Ao contrário do que comumente se acha, a maioria dos moradores de rua são

economicamente ativos. Longe do preconceito de que o morador de rua é desempregado, essa população: "(...) é composta, em grande parte, por trabalhadores, sendo que $70,9 \%$ deles exercem alguma atividade remunerada e 59,6\% afirmaram ter alguma profissão". A mendicância foi por muitos séculos a estratégia de sobrevivência dos moradores de rua, combinando-se com roubo e prostituição. A chegada do urbano, após a era industrial, trouxe funções secundárias e terciárias, às quais os moradores de rua se adaptaram. A industrialização de labores fez com que se gerassem atividades de baixa qualificação, as quais foram relegadas ao setor informal. As atividades de baixa qualificação se relacionam ao setor de serviços; são variadas, pouco valorizadas e mal remuneradas (QUIROGA / RODRIGUEZ -org-, 2009, p. 93).

As estratégias de subsistência são produto da ação recíproca entre os recursos e a inventividade, pois os moradores de rua ora percebem uma necessidade não satisfeita, ora criam uma oportunidade de trabalho informal. Em conjunto, as características das estratégias de sobrevivência das pessoas que moram nas ruas fazem com que eles 
sejam parte dos grupos que, "designados como subproletariado ou quarto mundo, muitas vezes compostos em proporção significativa por imigrantes, participam de forma irregular e periférica dos pólos dinâmicos do mercado de trabalho capitalista" (VIEIRA / BEZERRA / ROSA, 1992, p. 20, 82).

Cada uma das estratégias de sobrevivência possui um certo grau de contravenção, a maioria delas desenvolvendo-se no espaço público e no mercado informal. A metade dos entrevistados no primeiro censo afirmou que teve uma carteira assinada no passado, e cerca de $2 \%$ dos moradores de rua afirmaram ter uma carteira de trabalho assinada ativa no momento da pesquisa. Os comportamentos dos moradores de rua podem ser vistos como uma tentativa de adaptação ao seu entorno; na informalidade, eles desenvolvem ferramentas para sobreviver. Afirma-se que as estratégias de sobrevivência dos moradores de rua se adaptam conforme a temporada do ano e o lugar em que estejam nessa temporada. Elas também podem ser desenvolvidas simultaneamente; isso constitui uma escolha individual, conforme as suas necessidades mais urgentes. Os estudos do século passado revelaram o seu caráter temporário: o morador de rua "finds in casual and seasonal labor a kind of occupation congenial to his temperament, for the hobo is the bohemian in the ranks of common labor"3 (PARK, 1952, p. 94).

A natureza das atividades faz com que os moradores de rua não possam depender delas por longos períodos, pois o que funciona hoje pode não funcionar amanhã, não

3. Tradução livre: "encontra no trabalho casual e temporário uma espécie de ocupação congenial a seu temperamento, pois o morador de rua é o boêmio nas fileiras do trabalho comum". 
existem certezas nesse assunto. O caráter temporário faz com que não consigam ter estabilidade econômica ou confiança na sua identidade social para reintegrarse à sociedade. Essas atividades temporárias permitem-lhes obter os ganhos para adquirir comida, cigarros ou álcool. Para os moradores de rua, o mercado de trabalho é rotativo, especialmente para aqueles que se inserem na construção civil. As vagas temporárias se relacionam com o mercado de trabalho na cidade, pois em períodos de escassez de mão de obra é notável que se reduz a vagabundagem e a mendicância. Uma parte da população de rua, portanto, constitui nesses momentos um lumpemproletariado. Em geral, ao morar na rua, essa população atribui um novo significado ao uso do espaço público, em todos os aspectos de suas vidas, e o trabalho não é exceção; a maioria das estratégias de sobrevivência se desenvolve no espaço aberto, porque se vive na rua. A troca constitui ação que assegurou a sobrevivência dos moradores de rua durante séculos, relacionada ao comportamento mais primitivo desse grupo, sendo um traço que se conserva até hoje. Embora a parta da população pertença a um grupo etário jovem, carecem da qualificação técnica para desenvolver atividades remuneradas no setor formal.

Na cidade de São Paulo, especificamente na área central, há várias fontes de sobrevivência, logo deve apagar-se a imagem do mendigo tradicional, que sobrevive de esmola. Além disso, alguém que trabalha na rua não necessariamente mora na rua, pois pessoas que têm moradia fixa (precária ou formal) extraem renda dos serviços informais que oferecem no espaço público (camelôs, funileiros, pipoqueiros, baleiros entre outros). O centro da cidade oferece um arsenal 
de recursos e oportunidades para subsistir; hoje registram-se doze estratégias de sobrevivência dos moradores de rua: 1) catação de lixo, 2) guarda de automóveis, 3) construção civil, 4) limpeza, 5) estivagem, 6) biscate, 7) carregador/encartador de jornal, 8) artes circenses, 9) mendicância, 10) furto, 11) trabalho sombra, 12) trabalho escravo.

A catação de lixo é praticada pelos moradores de rua, sendo comum o mergulho no lixo em busca de comida ou materiais para abrigo; em certo momento, essa atividade se constitui como remunerada. Hoje a catação é uma estratégia comum, constituindo a fonte de renda de aproximadamente $60 \%$ da população de rua na cidade de São Paulo. Os ganhos variam, às vezes menos que um salário mínimo, às vezes mais, depende do trabalho de cada indivíduo. Ao pertencer a uma associação solidária, os integrantes têm uma cota mínima estipulada. O horário é da maneira que melhor Ihe convier, mas, na maioria dos casos, é um trabalho diurno com pausas para refeições, e geralmente não se trabalha aos sábados. O caráter lucrativo da atividade fez com que outros indivíduos, fora da população de rua, também desenvolvessem essa atividade. É importante assinalar que, em São Paulo, os catadores de lixo devem registrar-se na Prefeitura da cidade, o que aos olhos da sociedade paulistana Ihes dá certa legitimidade, conquistada como consequência de suas lutas sociais.

A Pesquisa Nacional dos Moradores de Rua (PNMR) feita em 2009 mostrou que catar materiais recicláveis constitui a estratégia utilizada por 27,5\% da população em situação de rua fora de São Paulo. Alguns estudiosos consideram que "o último recurso é a catação de lixo, mais comum entre os mendigos tradicionais e os doentes mentais" (SAEKO / SANTOS, 2006, p. 151). 
Em São Paulo, os catadores de lixo se agrupam em cooperativas a fim de compartilhar gastos e ganhos. Cada associação tem as suas regras em relação aos ganhos; algumas descontam os custos de manutenção da remuneração, outras não. Agruparse em uma cooperativa permite obter preços mais competitivos, uma renda regular, mercados mais amplos para a venda e conseguir mais equipamento para as tarefas. Uma das práticas mais comuns entre os catadores é a coleta seletiva. O fato de que um grupo de pessoas consiga transformar lixo em material produtivo merece reconhecimento: "mesmo em condições precárias ou adversas, próprias da miséria material, podem ser observados traços que manifestam características notáveis do povo brasileiro e expressam dados positivos" (GUSMÃO, 2004, p. 18).

Apesar de procurarem, por meio da catação, uma renda a partir de um trabalho digno, não escapam do preconceito. Os catadores se expõem às mesmas práticas repressivas e revanchistas praticadas contra toda a população de rua. Existem aqueles que dão apoio aos catadores, mas são raros. Também existem casos em que o lucro da catação pode levar a ganhos, exemplo disso é "El Gringo", que tem várias carroças e obtém ganhos do aluguel delas ou da comissão tirada do trabalho de outros. Alguns moradores de rua guardam automóveis e são conhecidos como "flanelinhas". A PNMR assinala que $14,1 \%$ da população de rua atuam como "flanelinhas" a fim de sobreviver. Essa atividade consiste em guardar e lavar os veículos estacionados na rua. Note-se, novamente, que não é uma atividade exclusiva dos moradores de rua. A construção civil é outra atividade desenvolvida pelos moradores de rua. A PNMR indica que $6,3 \%$ trabalham como diaristas de construção civil, mas sem que isso venha a ser uma prática regular. A quantidade de moradores de rua que se dedicam 
a essa atividade também indica que, por demandar uma força física considerável, não pode ser praticada por todos. Outros moradores de rua limpam diferentes espaços em troca de comida ou dinheiro. Uma porcentagem de $4,2 \%$ da população se dedica à limpeza de vários locais. O fato de que uma pequena porcentagem da população pesquisada se dedique a esse serviço pode indicar que ele é feito por mulheres em condição de rua: "o trabalho das mulheres se divide basicamente entre serviços domésticos - faxineira, lavadeira etc. - e os de vendedora ambulante" (VIEIRA / BEZERRA / ROSA, 1992, p. 83).

Identificam-se também "biscateiros"; essa atividade consiste em vender na rua, mas se diferencia dos camelôs por não permanecerem em um mesmo local. O carregador/ estivador se encarrega de carregar ou estivar pacotes grandes para comércios formais ou informais; essa atividade é praticada por 3,1\% da população de rua. Identificam-se moradores de rua perto da zona cerealista e do mercado municipal no centro da cidade de São Paulo, eles oferecem seus serviços aos lojistas ou compradores. Dentre as atividades mais visíveis dos moradores de rua estão as artes circenses. Usualmente é praticada por jovens e crianças em condição de rua. Os espaços públicos são utilizados para esse propósito, especificamente as esquinas com semáforos com forte congestionamento veicular, calçadas e praças. A população de rua se relaciona historicamente com a mendicância como atividade de sobrevivência. O mendigo ou pedinte é uma figura de todo centro urbano. Na Europa da Idade Média, era uma prática incentivada pela Igreja Católica, pois se relacionava com a santidade idealizada de acordo com os ensinamentos de São Francisco de Assis. Foi assim que, na Europa, "acaba-se criado condições para o crescimento das atividades de 
mendicância e de suas formas mais evoluídas de organização". Na França, no final do século XIX, especula-se que "cada mendigo opera no setor que lhe é indicado e adota a técnica prescrita". As tradições populares, tanto na Europa quanto na América, enfatizavam a importância de se oferecer hospitalidade e alimento aos necessitados. Essas atitudes foram deixadas para trás nas grandes cidades, mas se conservam nas cidades pequenas. Posteriormente, na Era Industrial, seria considerada como uma atividade perigosa por ser oposta à ideologia do trabalho, da época em que se incentivava o "produzir". (SIMÕES, 1992, p. 21, 23).

Organizada ou desorganizada, é uma prática comum até hoje, mas é considerada em vias de extinção. A variedade de tarefas mais lucrativas atraem mais moradores de rua que deixam a mendicância aos doentes. São poucos, 15,7\% segundo a PNMR, os que se dedicam a mendigar nas ruas; eles tiram proveito da caridade, "por utilizarse da farsa e da simulação como subterfúgio para se conseguir a esmola" (SIMÕES, 1992, p. 21, 23 / QUIROGA / RODRIGUEZ -org-, 2009, p. 93).

Existem testemunhas de administradores de hospitais que encorajaram muitos internos a mendigar para pagar o tratamento médico, pois há falta de apoio público para tratar suas doenças físicas ou mentais, tendo que pagá-las eles mesmos. Note-se que é uma atividade que nem sempre é praticada por moradores de rua. O furto é outra atividade comum; estudos indicam que "o furto é mais frequente entre os 'vacilantes' e 'outsiders', os que estão há mais de seis meses na rua". É uma atividade praticada irregularmente; parece que decidem praticá-la em momentos de desespero ou quando alguma aliança os força. O importante para eles é garantir a sobrevivência; quando isso 
não é possível por meio de suas estratégias regulares, recorrem ao furto. Desenvolvese em diferentes escalas, o que implica que existem pequenos furtos justamente para suprir necessidades imediatas. Mesmo que seja uma prática pouco comum, existe uma maneira com que a população em geral lida com furto por parte da população de rua. A longa permanência dos moradores de rua que se dedicam a essa atividade em alguns bairros trouxe a oportunidade de conhecer seus padrões de comportamento e as áreas mais vulneráveis neles. Ao saber disso, os moradores dessas localidades se mantêm longe das áreas perigosas para não ser assaltados. Percebendo isso, os moradores de rua que furtam aprenderam a reconhecer os usuários novos ou irregulares, que, por ignorância, são alvos mais fáceis. Os moradores de rua respeitam certas áreas, aquelas em que a população em geral não faz denúncias; parece haver um acordo silente, mas existem exceções, pois cada área da cidade apresenta sua dinâmica particular. Alguns moradores de rua se vinculam com o trabalho sombra. Denomina-se como trabalho sombra qualquer trabalho que não segue as leis. Classificam-se nessa categoria "as estratégias de venda e comércio de objetos pessoais, o mercado do tráfico de drogas e prostituição, a 'venda de plasma' (sangue)" (SAEKO / SANTOS, 2006, p. 151).

O trabalho escravo é uma prática comum; parece impossível que hoje a prática da escravidão se desenvolva na cidade de São Paulo, mas existem setores que tiram proveito da situação informal e da necessidade dos moradores de rua. Existem épocas do ano propícias para os trabalhos temporários; nesses períodos, geralmente, os empreiteiros (chamados "gatos urbanos"), saem para procurar empregados na cidade. Esses trabalhos, além de serem pesados e sem segurança física, não têm 
garantias trabalhistas e são mal remunerados. No centro da cidade, o Bairro Brás é conhecido pelos moradores de rua como o ponto onde os "gatos" procuram a mão de obra. São famosas as "Kombis do Brás", onde os "gatos" selecionam os trabalhadores mais aptos para os trabalhos. Aqueles com força física são selecionados, o que quer dizer que, dos muitos moradores de rua, poucos são selecionados. As promessas feitas pelos "gatos" são muitas; às vezes os trabalhos são em outras cidades, e as promessas sobre as condições ou a remuneração nem sempre são cumpridas.

Não são todos os moradores de rua que conseguem fazer um trabalho pesado. Tarefas extenuantes só conseguem ser efetuadas por pessoas com força física os moradores de rua nessa condição são poucos e, em sua maioria, estão na rua temporariamente. O morador de rua em condição crônica - que não se alimenta regularmente, dorme por pouco tempo e tem alguma doença física ou mental - não consegue desenvolver trabalhos pesados. 


\section{CAPITULO 3}
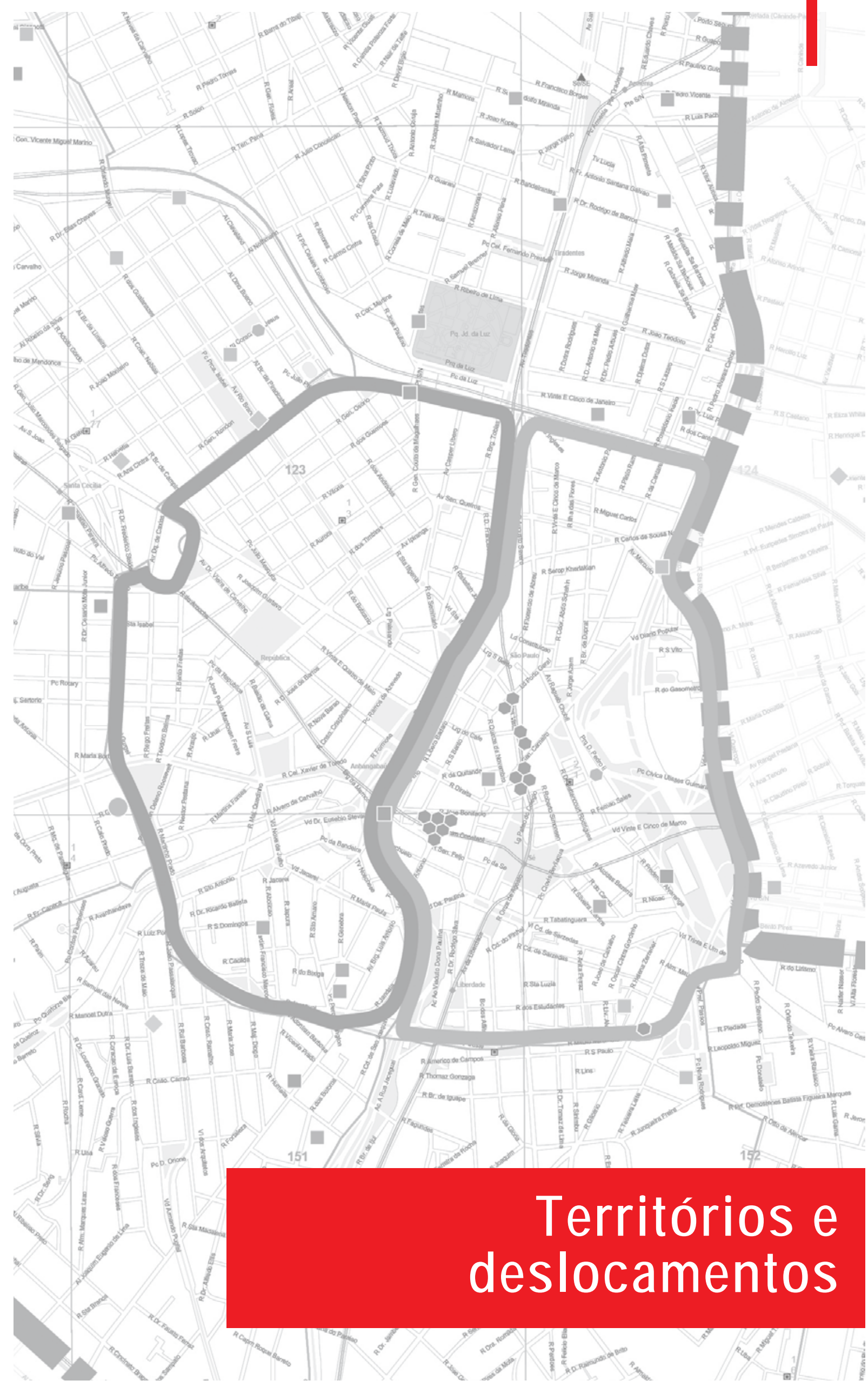

1)

\% 


\subsection{OS TERRITÓRIOS ONDE SE CONCENTRAM}

As observações empíricas que orientaram o desenvolvimento dos primeiros censos indicaram o centro da cidade como o lugar do início para as contagens desenvolvidas pela Prefeitura. A sistematização das pesquisas durante o período de 1991 até 2011, permitiu confirmar que "a rua" não é para seus moradores um espaço indiferenciado e identificaram o centro como o lugar da cidade que concentra a maioria da população de rua. As contagens também asseguram que há crescimento do fenômeno de rua em outras áreas da cidade, fato identificado ao se comparar as contagens dos anos 2000 e 2009 (ver Tabela II abaixo). Em relação à presente pesquisa, decidimos concentrar os esforços no centro da cidade porque este local reúne diferentes instituições religiosas, administrativas/públicas, financeiras e de transportes; logo atrai a população que procura abrigo ou assistência social. A concentração de comércio na área também apresenta possibilidades de ganho mediante trabalho informal, o que é bastante atraente para essa população.

A tendência geral na cidade de São Paulo é o crescimento da população de rua. Nos últimos dez anos, os distritos de Sé e Mooca constituíram-se como as áreas onde se concentra a maior parte da população em situação de rua (ver Tabela III abaixo). As contagens também indicam um caráter flutuante da população em uma escala menor, pois nos censos registra-se o crescimento da população de rua em cada distrito. Em 2009, as concentrações de população de rua na Subprefeitura Sé (28\%) e Mooca (12\%) se destacam na cidade. 


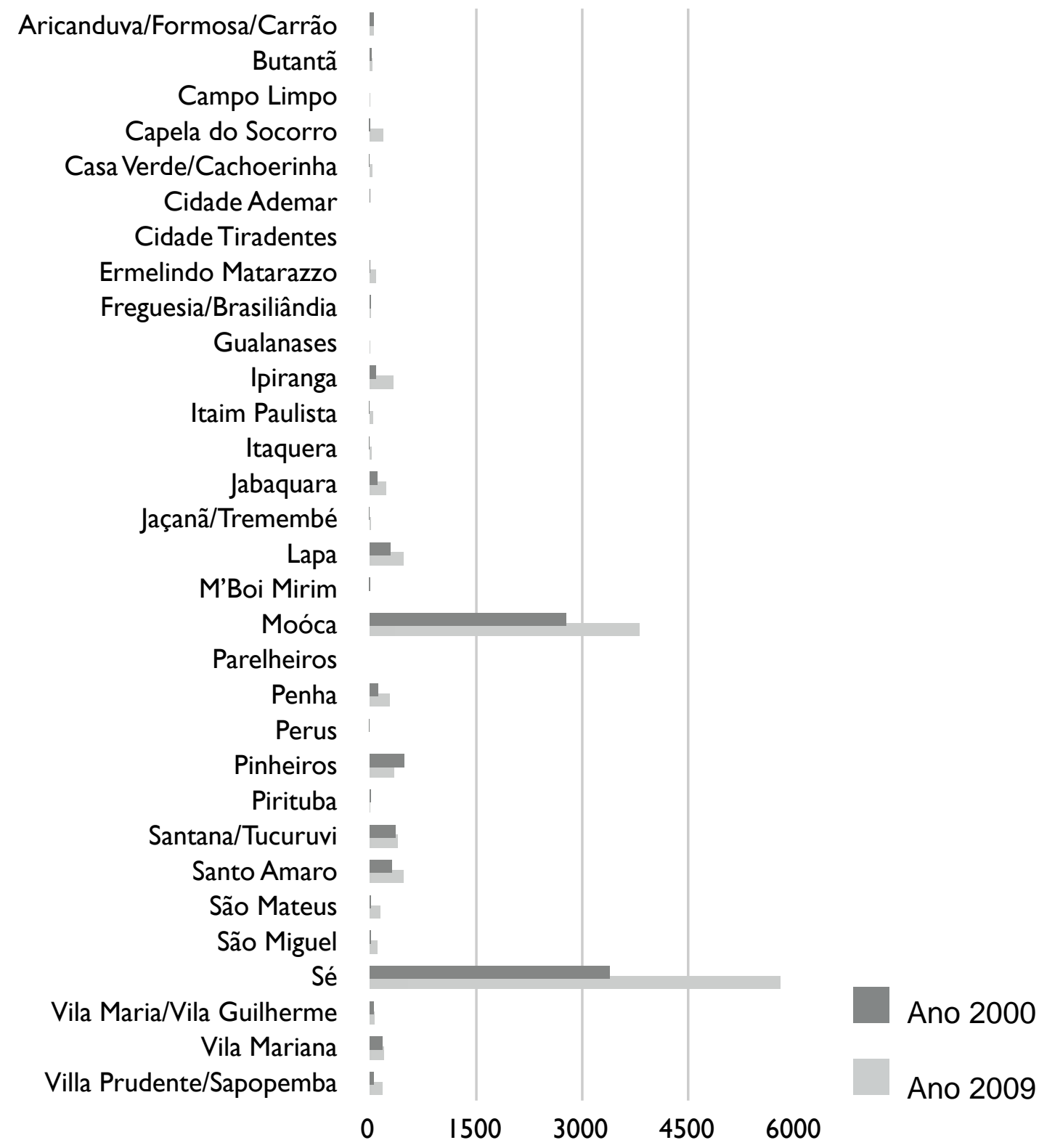

\section{Gráfico 2 - Contagem dos moradores de rua na cidade de São Paulo} (2000-2009)

Fora do centro, algumas subprefeituras apresentam um crescimento surpreendente: Capela do Socorro passou de 17 (2000) a 201 (2009) moradores de rua; no global, isso representa um crescimento de $2 \%$, mas, em relação a essa área, é um crescimento de mais de 1.000\%. As Subprefeituras de Ermelino Matarazzo, Itaim Paulista e São Mateus apresentam um crescimento de mais de 400\%. Nas Subprefeituras de Casa Verde/Cachoeirinha e São Miguel, o crescimento no período visto foi de mais de 300\%. 


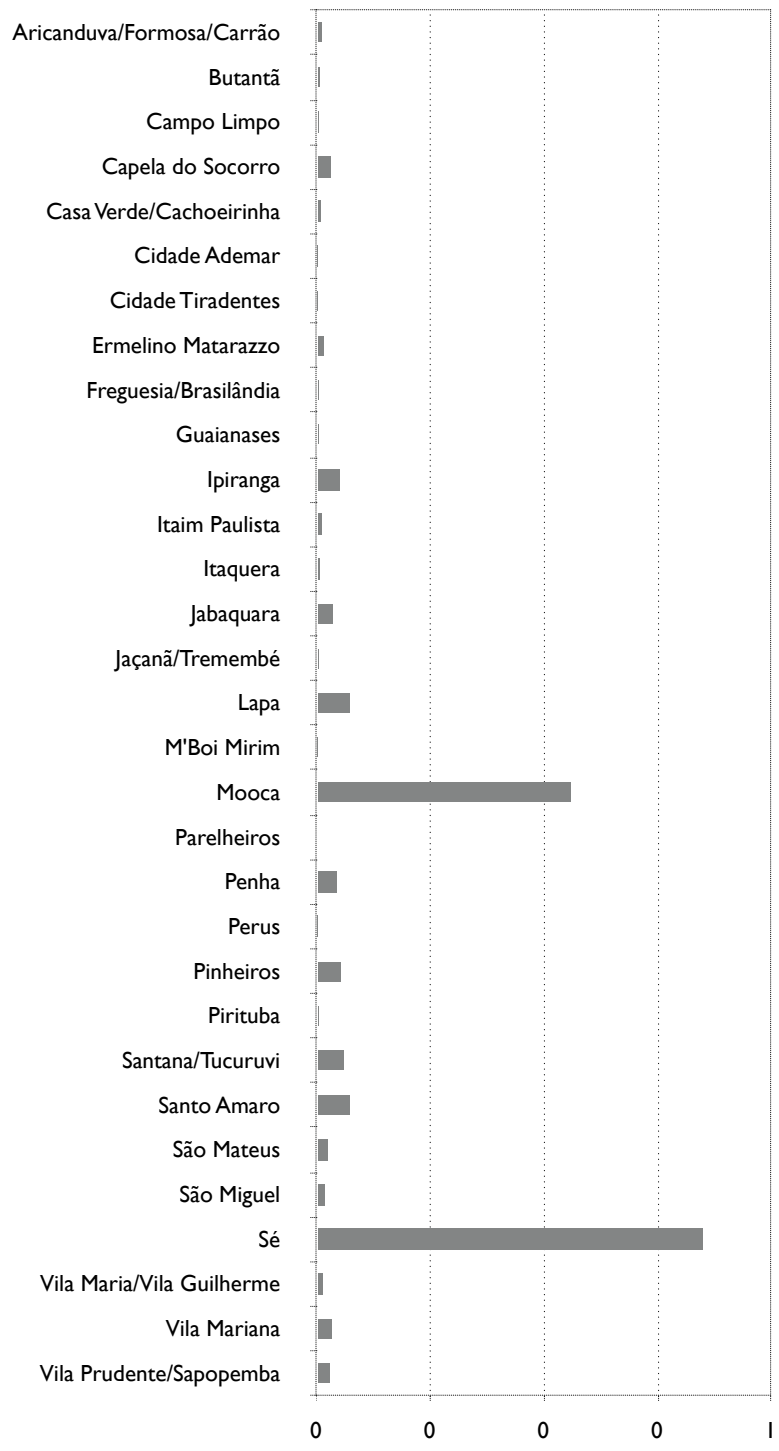

Gráfico 3 - Porcentagem do crescimento da população de rua na cidade de São Paulo

Essas áreas na cidade, mesmo carecendo do equipamento de assistência social especializado, tornaram-se focos de crescimento da população de rua. A Subprefeitura de Pinheiros se destaca por apresentar uma redução significativa: de 509 (2000) passa a ter a 352 (2009) moradores de rua. As Subprefeituras de Aricanduva/Formosa/ Carrão, Cidade Ademar, M'Boi Mirim, Perus e Pirituba apresentam uma redução mínima de moradores de rua. Essas variações assinalam o caráter flutuante da população de rua em toda a cidade de São Paulo. 
Nas pesquisas relacionadas com os refúgios dos moradores de rua, surgem fatos importantes, pois assinalam que muitas das favelas tiveram início com a ocupação local por parte de moradores de rua. Parece que os moradores de rua lideram a tomada dos espaços destinados à moradia informal. Assinalou-se já na presente pesquisa a relação entre favelas, cortiços, pensões e a rua; pois esses são simplesmente estágios, às vezes transitórios e emergenciais, da moradia precária na cidade de São Paulo (PEREIRA / SANTOS, 1998, p. 0760).

Em todas as áreas ocupadas pelos moradores de rua, registram-se duas dinâmicas distintas: a diurna e a noturna. Adiciona-se a isso o fato de que cada território, em menor escala, possui dinâmicas próprias. Durante o dia, uma porção da população de rua procura as áreas mais transitadas da cidade, seja para mendicância, para dormir ou para desenvolver alguma das estratégias de subsistência. Existem, no centro da cidade, espaços característicos nos quais os moradores de rua se concentram durante o dia; o melhor exemplo é a Praça da Sé. Esse espaço da cidade possui duas dinâmicas, que se marcam claramente: de dia, muitos moradores de rua se congregam em grupos, compartilham alimentos ou simplesmente batem papo; à noite, esse espaço, esvaziado, é perigoso, até mesmo para os moradores de rua, devido à prostituição, ao furto e ao tráfico de drogas - portanto muitos dos moradores de rua o abandonam nesse período, procurando outras ruas para pernoitar. Registram-se poucos moradores de rua que pernoitam na Praça da Sé (SANTOS, 2005, p. 225).

À noite, os moradores de rua desenvolvem outras dinâmicas, muito mais complexas. Uma parte do povo da rua procura as áreas abandonadas, longe do olhar público, 
o que facilita sua ocupação e permite a liberdade para realizar algumas atividades ilícitas. Os espaços residuais tornam-se o nicho noturno dos moradores de rua. Outros moradores de rua procuram os espaços mais concorridos, a fim de poder dormir e evitar situações de perigo.

\subsubsection{O CENTRO DA CIDADE}

Após a crise econômica da década de 1970, foi fácil identificar o crescente povo da rua na cidade de São Paulo. Por desconhecer a quantidade de pessoas que se achavam em situação de rua, a prefeitura passa a focar suas ações nas áreas onde se percebeu uma grande concentração delas; nesse contexto, inicia-se o trabalho das contagens (a partir de 1991 e continuando pelo menos até 2011, ano anterior ao início deste estudo), que foi orientado originalmente pelos dados provenientes de plantões de atendimento à população carente da prefeitura. Nos censos da última década, a bagagem de experiência do pessoal da Prefeitura permitiu a realização de mudanças na metodologia e sistematização dos dados das contagens, o que assinala uma melhora na qualidade dos dados da última década.

Os primeiros dados dessas contagens apresentam clareza em relação à procura dos espaços centrais das cidades. A maioria dos moradores de rua são originários das áreas urbanas; seu processo de adaptação à vida de rua é facilitado por possuírem conhecimentos dos recursos disponíveis na cidade. As pesquisas no assunto também indicam que "muitas vezes a disponibilidade de recursos acaba gerando a concentração dessa população em certos pontos nas cidades". A presença mais 
expressiva dos moradores de rua em certas áreas das cidades faz com que os espaços sejam apropriados por estes, passando a ficar estigmatizados por se relacionarem com a população em condição de rua (QUIROGA / RODRIGUEZ -org-, 2009, p. 139).

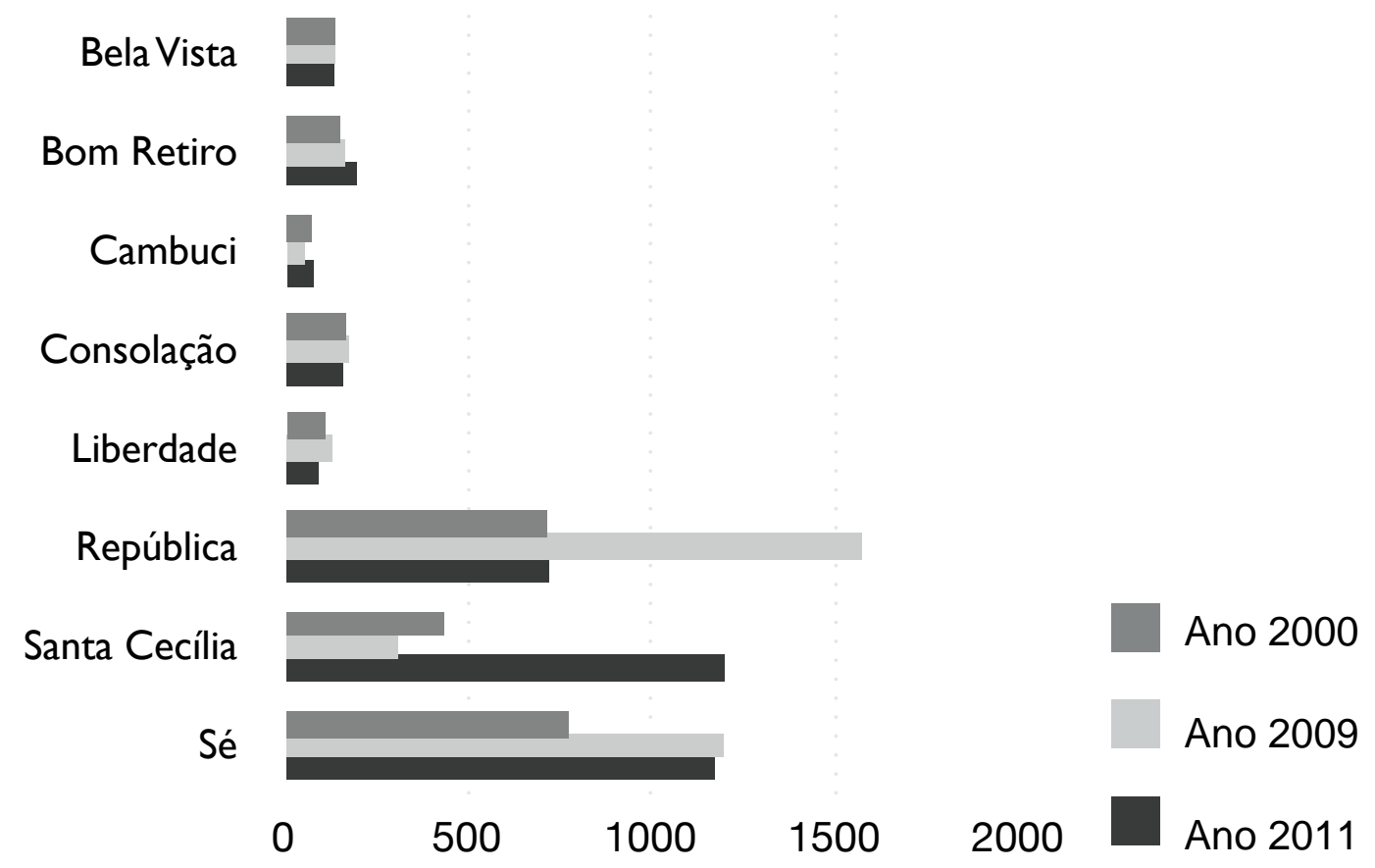

Gráfico 4 - Moradores de rua no centro da cidade de São Paulo 2000 - 2011

A procura do centro parece lógica, pois nessa área da cidade eles obtêm os recursos para garantir sua sobrevivência. O lixo do comércio nas áreas centrais das cidades constitui uma fonte de inumeráveis recursos: sobras de comida, materiais para refúgios e objetos para troca. No centro, eles também podem obter alimentos gratuitos por meio de entidades filantrópicas ou mergulhando no lixo dos restaurantes. Além disso, a grande circulação de pessoas durante o dia permite-lhes obter subsistência através da mendicância, do furto ou de trabalhos informais (Ver página 61). Por tudo isso, o centro da cidade exerce um grande poder atração sobre a população de rua. 
Primeiro, o abandono de certas áreas é outra "vantagem" do local, pois ocupar suas antigas áreas industriais, os prédios e os espaços públicos (viadutos, praças e ruas) fica mais fácil, já que esses espaços carecem de "vigilância". Segundo, o constante fluxo de apoio social, especificamente dirigido a essa população, gera o interesse de muitos moradores de rua, o que assegura sua permanência no setor e atrai os recém-chegados Os pesquisadores acumularam, ao longo de uma década de estudos, conhecimento em relação aos logradouros da cidade onde se concentravam os moradores de rua em São Paulo na década de 90: "uma contagem realizada pela Secretaria do Bem-Estar Social na Regional da Sé e proximidades, constatou a presença de 3.400 pessoas pernoitando em mais de 300 pontos diferentes". As informações dos censos de 2000 e 2009 indicam as dinâmicas de crescimento na área central da cidade. Alguns distritos da Subprefeitura Sé apresentam variações significativas, das quais tanto as da Sé, quanto as da República constituirão o foco da presente pesquisa (SIMÕES, 1992, p. 29).

Os censos e estudos da década de 90 levantaram informações dos locais preferidos pelos moradores de rua e confirmaram o que as observações empíricas haviam registrado inicialmente. Muitos descem gradativamente à vida na rua, de favelas a cortiços, de cortiços a pensões. O último grau desse descenso social e econômico é a rua, em que as pessoas procuram espaços públicos da cidade para pernoitar. A exclusão social os leva a procurar os espaços abandonados e residuais da cidade, especificamente na área central. O resultado do processo de degradação do centro da cidade de São Paulo foram espaços passíveis, prontos para serem ocupados por outros atores que gradativa e silenciosamente tomaram conta desses "vazios". 
No marco do primeiro censo realizado pela Prefeitura, uma vez identificados os logradouros, o censo permitiu conhecer as dinâmicas dos moradores de rua neles. Sabe-se hoje que na década de 1990, nos períodos de tempo em que foram ocupados como espaço de pernoite, que "desses [locais], 64\% existem há mais de um ano, e 24,6\% há mais de cinco anos. (...) Por outro lado, 35,8\% dos pontos surgiram há menos de um ano, e 27,2\% há menos de seis meses" (VIEIRA / BEZERRA / ROSA, 1992, p. 60).

Cada lugar apresenta uma dinâmica distinta. As ruas e avenidas mais concorridas constituem o dormitório de muitos moradores de rua, seja de dia, seja de noite. Os moradores de rua procuram ruas com prédios comerciais, preferencialmente com marquises para se proteger contra a chuva ou o relento. As primeiras pesquisas assinalaram que menos da metade dos que pernoitam nas ruas ou avenidas se expõem ao relento; estes parecem ser os que não têm pertences. Especialmente no inverno, são bastante concorridos os espaços embaixo de viadutos e as praças. Os espaços públicos abertos apresentam outra dinâmica: as praças ou largos que têm prédios comerciais ao redor usualmente são concorridos pelos moradores de rua que tem utensílios (caixas, caixotes, carroças, plástico ou papelão). Usualmente eles utilizam os bancos ou árvores para se auxiliar na construção de um refúgio temporário. Menos da metade dos usuários dormem ao relento nesses espaços, que geralmente são disputados por grupos. Apresentam-se casos de moradores de rua que têm equipamentos de cozinha e aproveitam esses espaços. Na década de 1990, alguns desseslugaresseidentificaramcomofocosdeagressividadeeviolência, especificamente a Estação da Luz e a chamada Boca do Lixo, ambos localizados na Cracolândia 
Nos viadutos, apresentam-se práticas particulares, que indicam permanência e um sentido de pertencimento por parte de alguns moradores de rua. São o terceiro logradouro mais utilizado pelos moradores de rua; muitos deles se localizam perto das vias expressas, o que torna morar neles um risco. Procuram-se as laterais dos viadutos, onde se tenta reproduzir casas ou moradias formais. Muitos conseguem fazer desses espaços as suas moradias, a ponto de ter cozinha, mesas e armários improvisados. Por outro lado, identificou-se também que nem todos os espaços ocupados por moradores de rua são públicos. Os espaços privados ocupados por essa população foram inicialmente excluídos do primeiro censo, devido a seu caráter temporário. Nessas primeiras contagens, foram considerados como pouco significativos os terrenos baldios, canteiros, prédios abandonados, cemitérios, postos de gasolina e becos. É comum a presença de carroças estacionadas junto ao espaço de moradia, seja público ou privado. Nos espaços de moradia criados por eles é perceptível o encontro do formal e informal. Os refúgios incorporam elementos do ambiente construído e formal, sem deixar de lado a criatividade dos moradores de rua. Essas construções informais parecem mais comuns no século XX, seja porque após a era industrial são descartados materiais como papelão e plástico em grande escala ou porque o contingente de pessoas na rua é muito maior que antes. À medida que o século avança, mais estudiosos têm interesse em pesquisar os moradores de rua.

\subsection{O TERRITÓRIO PESQUISADO}


área se apresenta uma significativa concentração do fenômeno dos moradores de rua. O limite administrativo constituído pela Subprefeitura Sé é o maior território que encontramos ao refletir sobre o agir dos moradores de rua. O limite administrativo foi determinado em 2001 a partir da criação das Subprefeituras na cidade. Mesmo que a Subprefeitura Sé seja constituída por 8 distritos, a pesquisa focaliza dois: Sé e República. Dentro dos perímetros dos dois distritos, encontramos outros territórios em pequena escala que também serão analisados.

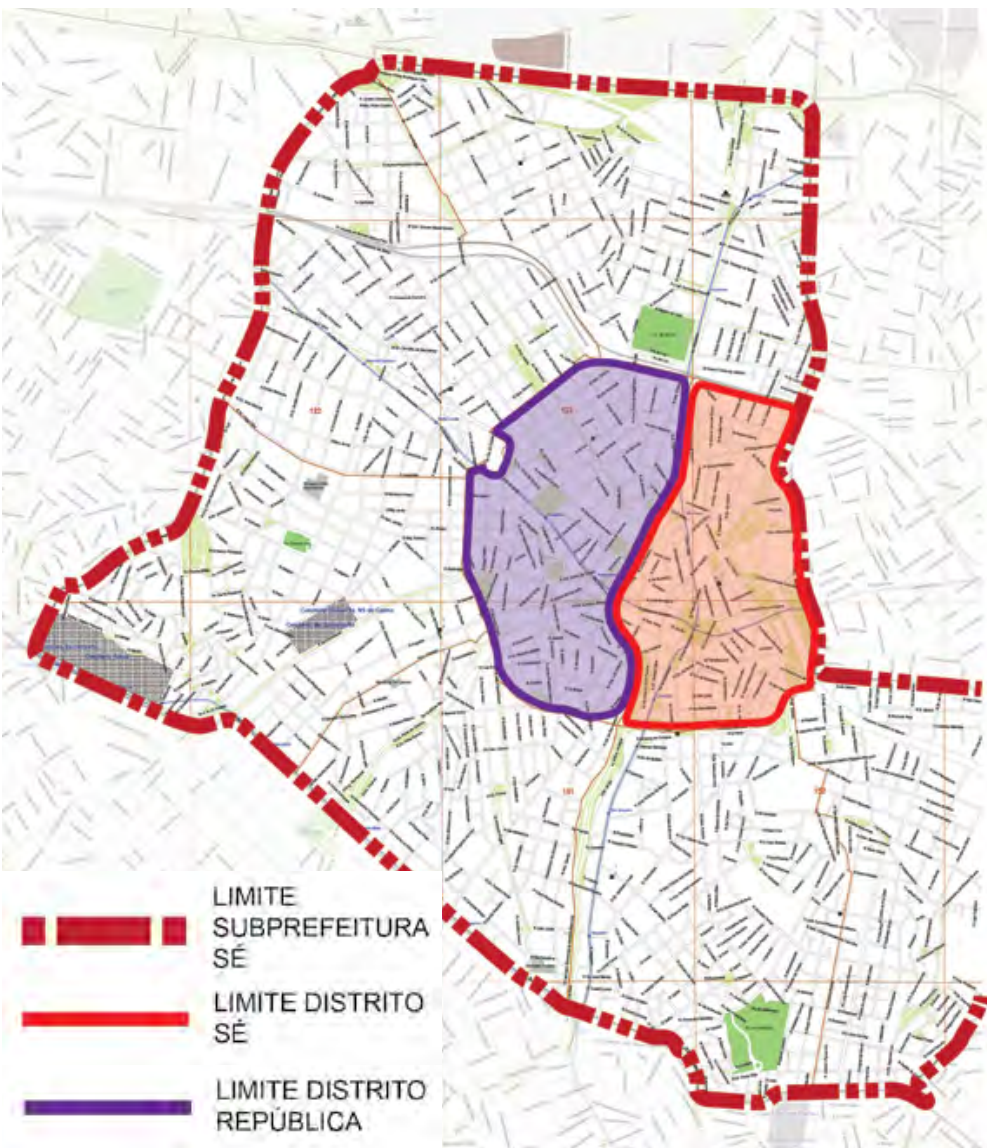

Mapa 6 - Limites administrativos da área central

Realizar as observações de campo com a equipe de Atendimento Urbano da Prefeitura, comoapoiodoCentroIntegradodeEstudoseProgramasdeDesenvolvimentoSustentável 
(CIEDS) constituiu o passo mais lógico, já que tanto seu território de ação, quanto

o território pesquisado coincidem. Constituído pelos distritos Sé e República, o território pesquisado se fragmenta ainda mais com dois tipos de limites: o funcional e o imaginado. Os perímetros desses territórios menores, chamados de "peças" pela equipe de Atendimento Urbano, são determinados pelo agir dos moradores de rua e possuem dinâmicas particulares.

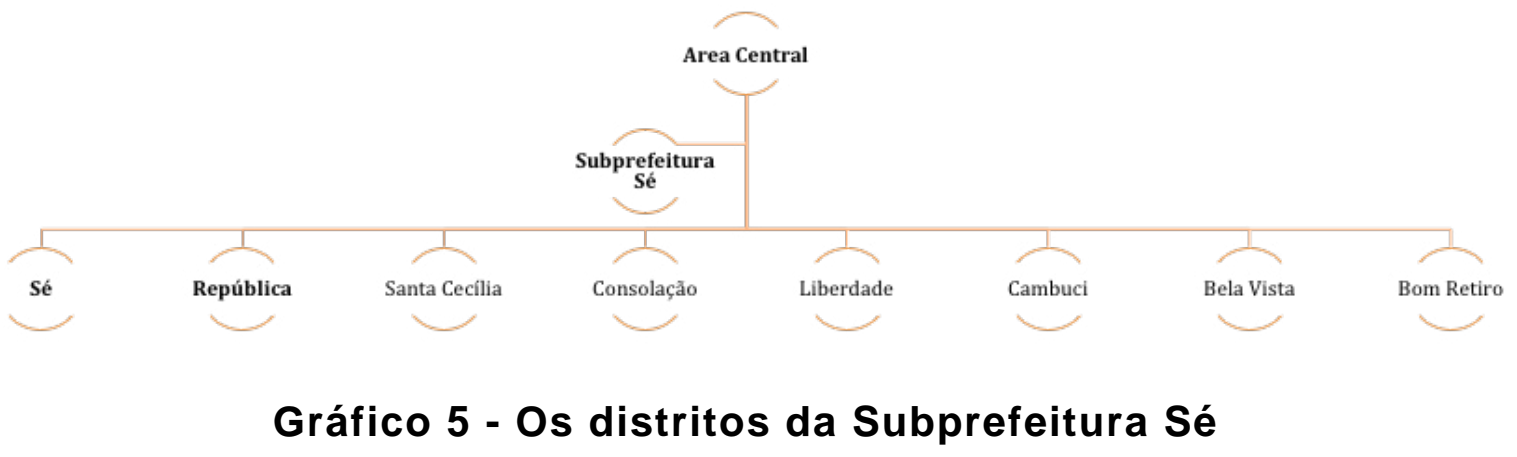

No total, nos distritos analisados, encontramos dez territórios menores, dois dos quais pertencem a outros territórios maiores fora da pesquisa: Cracolândia e Liberdade. Estes extrapolam o território pesquisado e possuem uma relação funcional com outros territórios também fora da análise, por isso não serão cobertos no presente trabalho, mas serão considerados como limites ou fronteiras da pesquisa em curso (Liberdade [fronteira] e Luz [fronteira]).

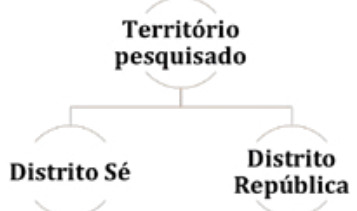




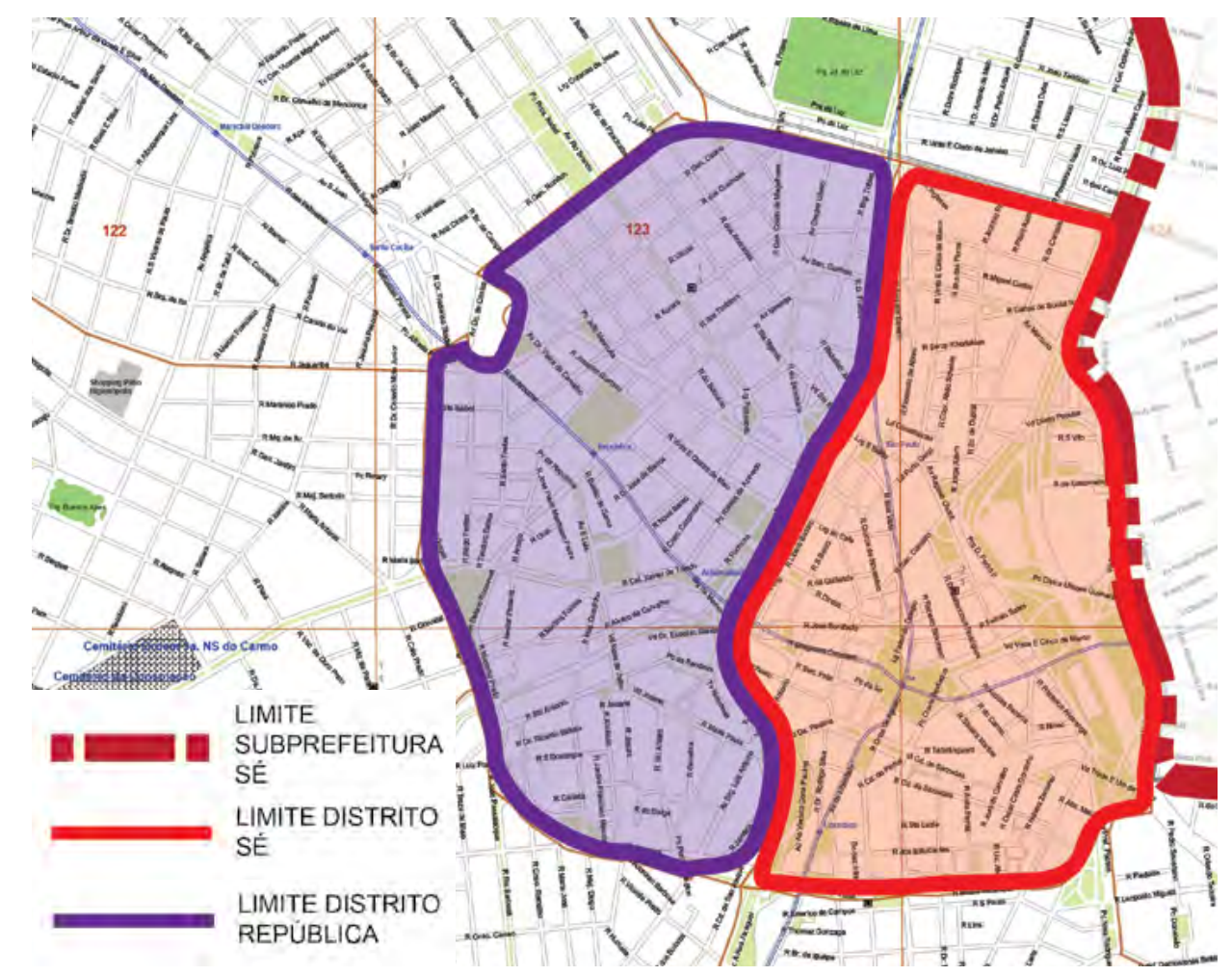

Mapa 7 - Distritos Sé e República

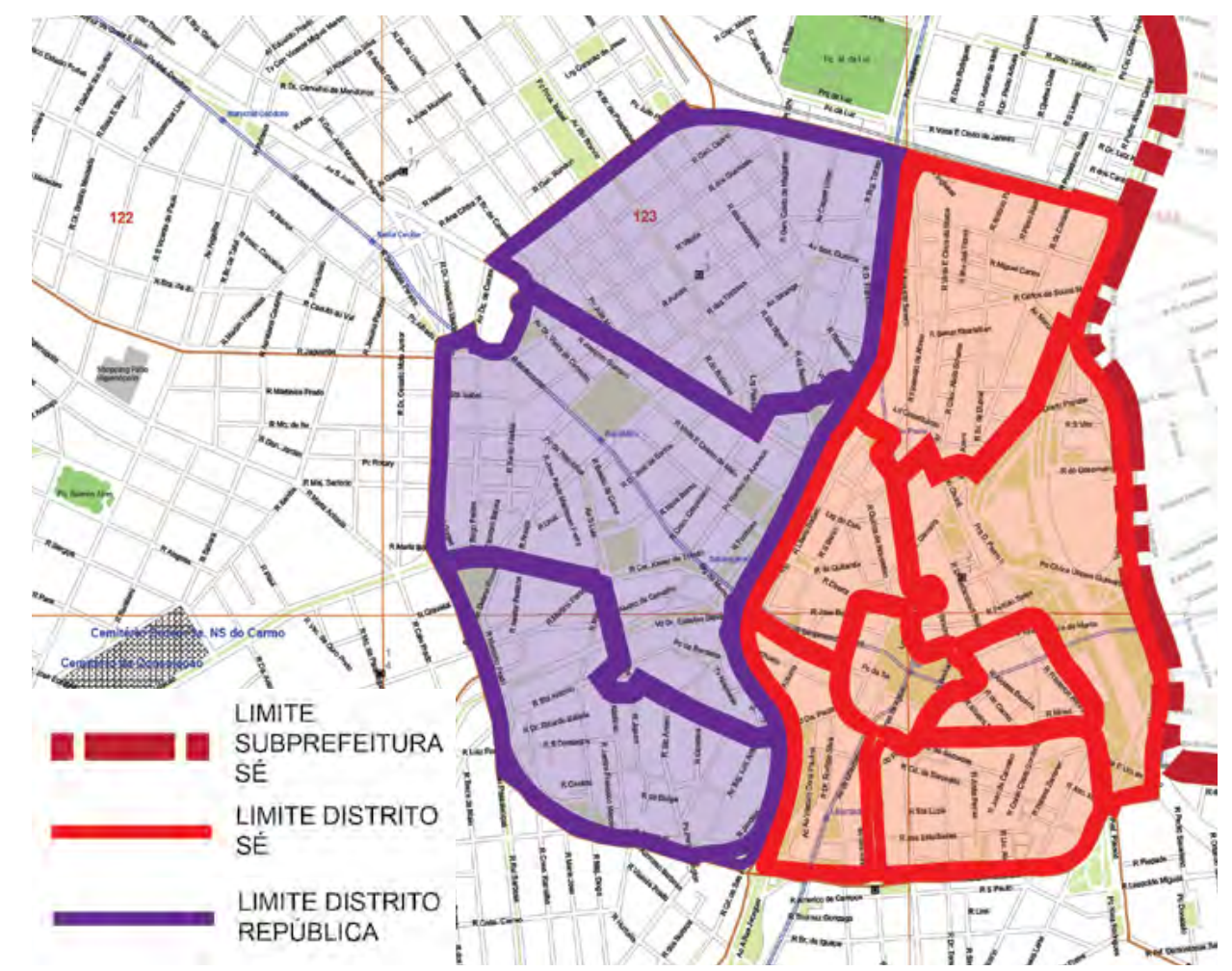

Mapa 8 - Distritos Sé e República e seus territórios menores 


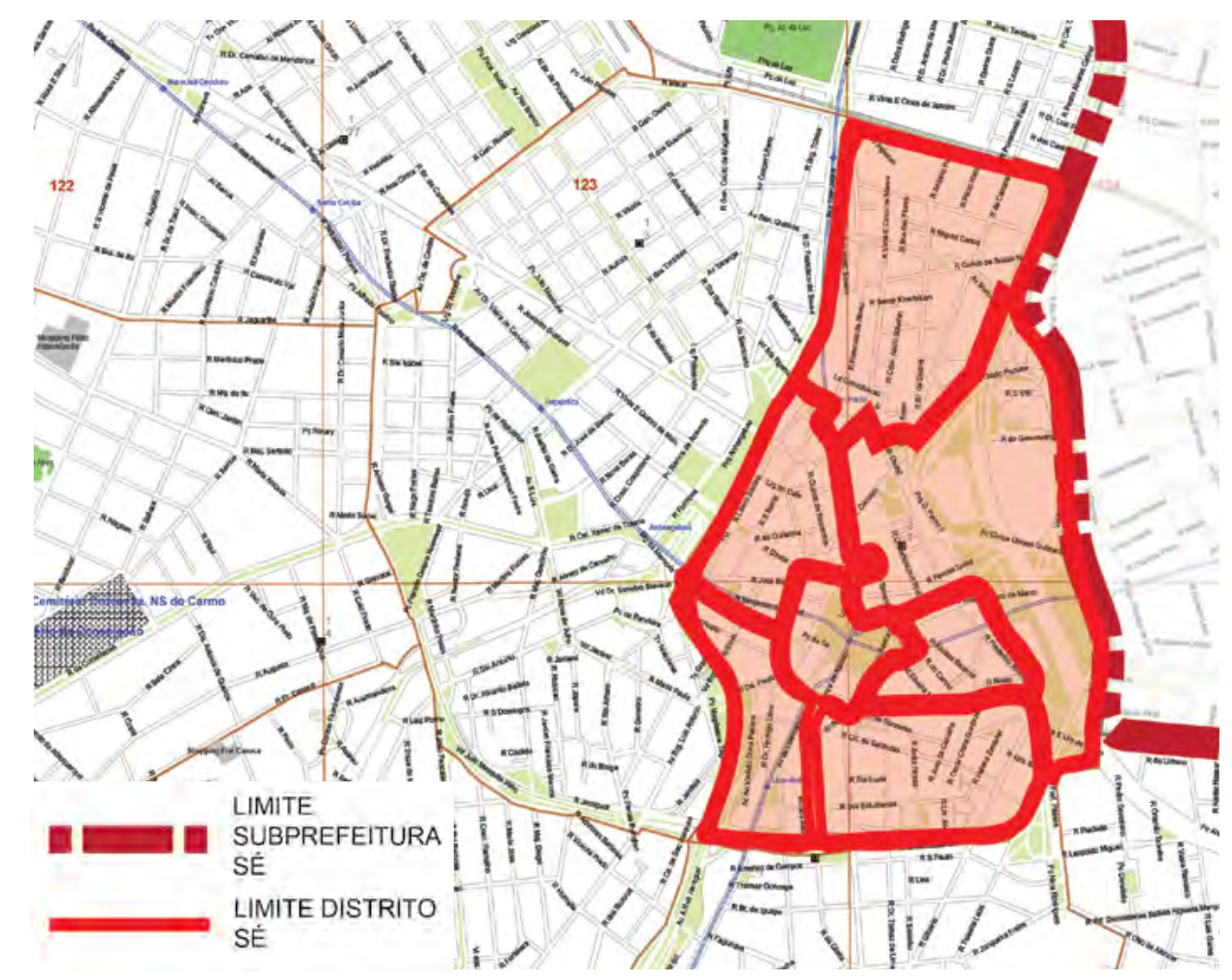

Mapa 9 - Distrito Sé e seus territórios menores

\subsubsection{DISTRITO SÉ}

$\mathrm{Na}$ análise, o distrito é composto por sete territórios menores. Esses perímetros menores consistem em ruas, largos e praças, em que se desenvolvem dinâmicas distintas. Após o fracionamento da Cracolândia, realizado com a Operação Luz (em fevereiro de 2012), observou-se a emigração de muitos moradores de rua que se localizavam na região da Luz. 


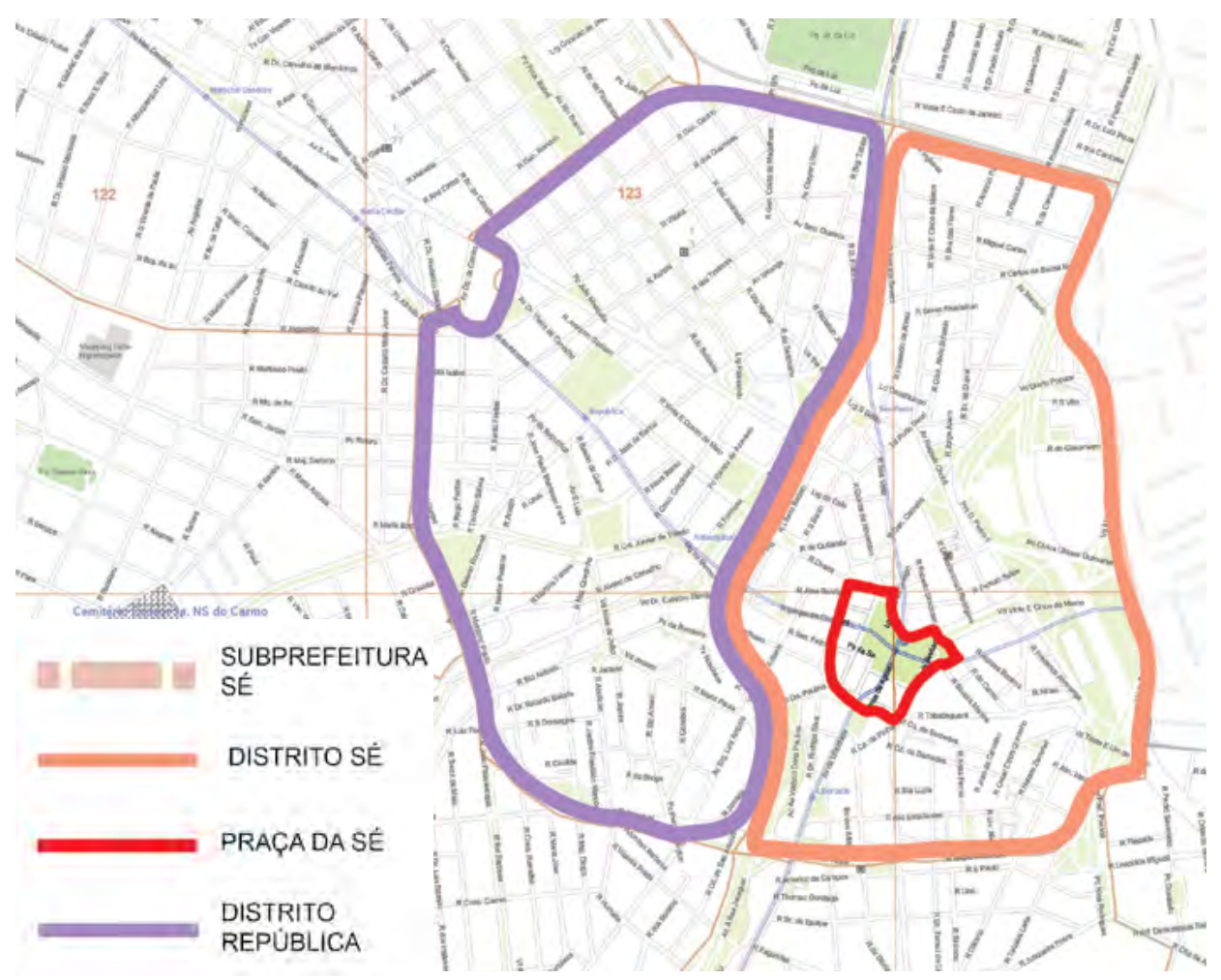

Mapa 10 - Perímetro 1

O Perímetro 1 tem como ponto central a Praça da Sé, pode parecer menor em tamanho, mas nesse espaço se congrega uma grande quantidade de moradores de rua. Diz-se: "Na Praça da Sé, nem pensar, pois é território dominado pelos menores de rua". O perímetro é formado pela Praça da Sé, Praça Doutor João Mendes, Praça Clóvis Bevilácqua e as ruas situadas entre elas. Embora a Praça da Sé esteja sempre ocupada, nem sempre é pelo mesmo perfil de morador de rua, pois aqueles que passam o dia nesse espaço pernoitam em ruas-dormitório ${ }^{4}$ na região . Identificamse moradores de rua pernoitando em tendas de lona e outros materiais na Praça Sé, especula-se que eles trabalham informalmente no setor (SIMÕES, 1992, p. 29).

4. Denominadas "dormitório" pelo fato de os moradores de rua se reunirem nelas para dormir. 
À noite, muitos moradores de rua se dispersam pelas ruas-dormitório por questões de segurança, pois nesse período a prostituição, os furtos, a venda e o consumo de sustâncias ilícitas geram um contexto tenso na região. Durante o dia, a circulação constante de pedestres permite que muitos moradores de rua subsistam por meio da mendicância, além disso entidades religiosas distribuem roupas e alimentos no setor, o que os atrai. Uma das vantagens desse perímetro é a variedade de ofertas em relação a comida, especificamente de "marmitex", que aqueles que trabalham informalmente acham a partir das 20h. Em relação à vida de rua, o setor também oferece um fácil acesso a bebidas alcoólicas, especificamente às de baixo preço.

Outra dinâmica vinculada à subsistência no setor é tanto o furto quanto a feira de rolo - depois de serem roubadas, coisas são vendidas nessa feira. Na Praça Clóvis Bevilácqua se congregam os usuários de crack; mesmo que entre períodos a quantidade de pessoas varie, constitui um ponto de referência para as malocas cuja interação se relaciona com o consumo de sustâncias ilícitas. Tanto a chuva quanto as ações da Guarda Civil Metropolitana (GCM) provocam a dispersão dos usuários desse espaço. 


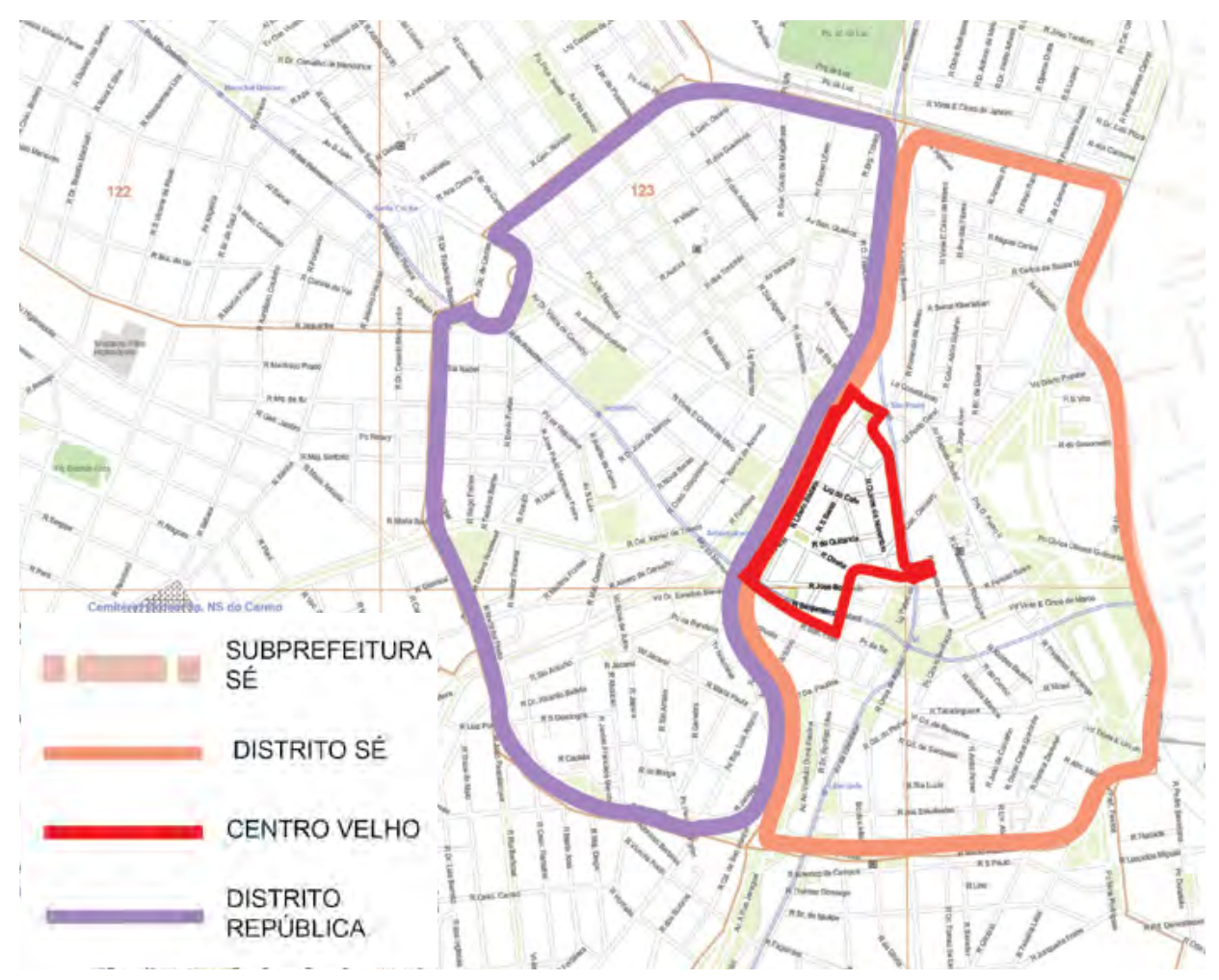

Mapa 11 - Perímetro 2

O Perímetro 2 é chamado de "Centro Velho", pois ele está constituído pelas ruas mais antigas da cidade, o triângulo tradicional que está fixado no imaginário dos cidadãos. Os moradores de rua conhecem a fundo a dinâmica do Centro Velho, especificamente, a escassa circulação de pedestres em certas ruas e espaços públicos. Essa ausência de pessoas constitui uma vantagem do território, em relação à vida de rua, pois os espaços abandonados são aproveitados para pernoitar ou consumir substâncias ilícitas.

Os períodos de permanência por usuários são curtos, mas como população eles ocupam o espaço regularmente, pois sempre existem moradores de rua novos no local. O Pátio do Colégio alberga poucos moradores de rua, sozinhos ou em grupos reduzidos. A Praça Manoel da Nóbrega constitui um ponto de encontro, apresenta a permanência de grupos que usualmente consomem álcool e cozinham ali. 
Nesse perímetro se localiza o Movimento Estadual da População em Situação de Rua, especificamente na Rua José Bonifácio 398, que abriga um centro de assistência coordenado por um antigo morador de rua, no qual os usuários obtêm fotos gratuitas e orientação legal. Em outros espaços públicos do setor, como a Praça do Patriarca, identificam-se moradores de rua "caídos", que consomem principalmente álcool. O Largo de São Francisco constitui outro espaço emblemático para o povo de rua desse perímetro; é caracterizado tanto pela distribuição de alimentos para essa população, quanto pela constante expulsão do povo de rua por parte das autoridades locais. Além de identificarem-se seis diferentes instituições que distribuem o "sopão" nesse espaço público, há também no local o "Chá do Padre", espaço na Rua Riachuelo em que se oferece orientação legal específica para as pessoas em situação de rua por parte da Defensoria Pública, além de comida, roupa e outros apoios.

As contagens realizadas indicam que também nas imediações entre Rua e Largo São Bento há uma ocupação visível: “em observações realizadas no início de 1991, foram identificadas cerca de 60 famílias dormindo ao longo da Rua São Bento, no trecho de 800m que separa o Largo de São Francisco da Igreja de São Bento". Embora a permanência dos moradores de rua nesse setor seja por períodos curtos, em geral os espaços sempre estão ocupados pela população de rua, o que indica que o setor é uma espécie de espaço de passagem, em que certos processos relacionados com a vida de rua são facilitados, por exemplo a inserção nessa forma de viver e o início de alguma estratégia de sobrevivência. No caso do Largo de São Bento, talvez por sua proximidade à Igreja, desenvolve-se a mendicância, obtendo-se ganhos significativos (SIMÕES, 1992, p. 29). 


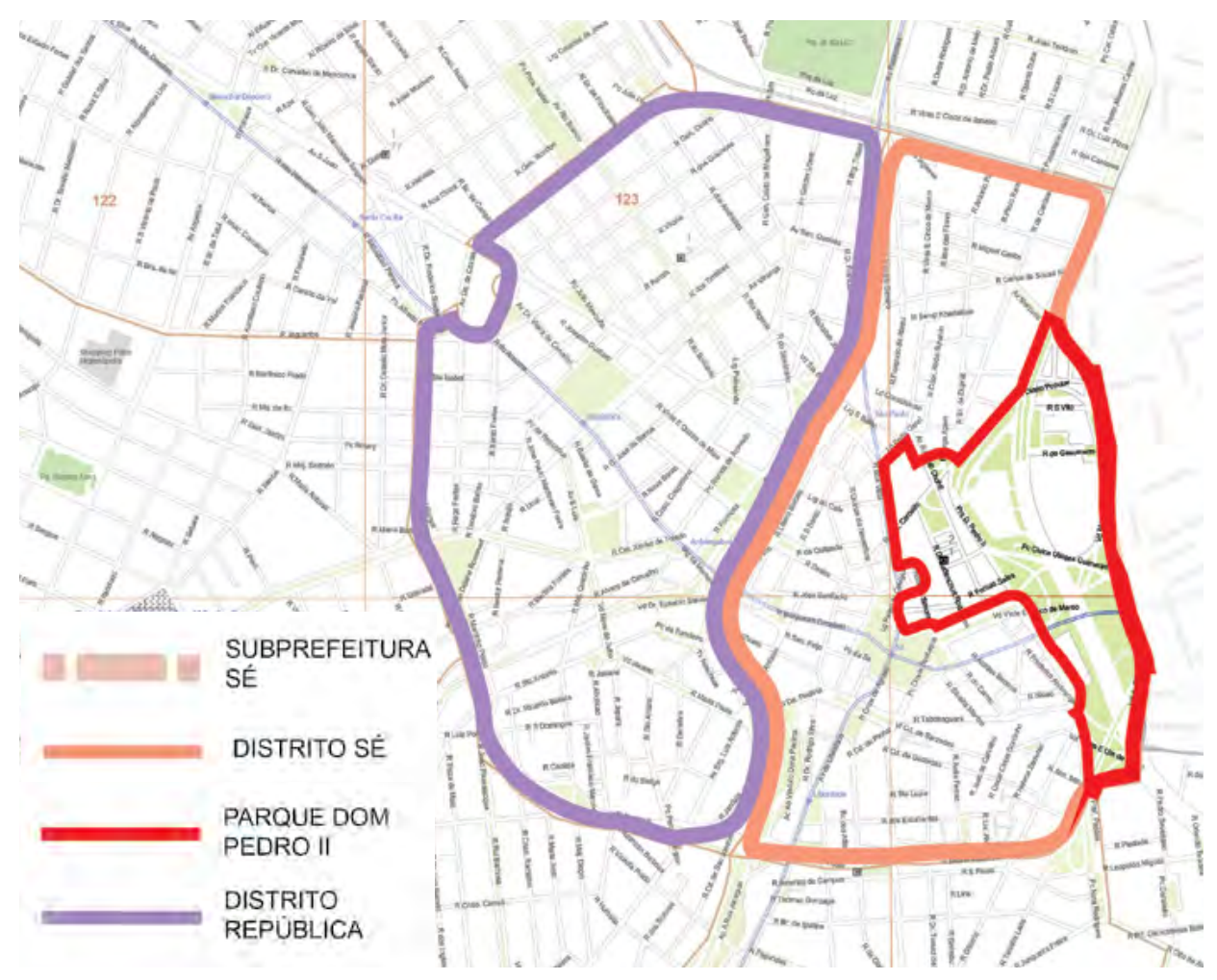

Mapa 12 - Perímetro 3

O Perímetro 3 tem como ponto central o Parque Dom Pedro II, esse é um dos espaços públicos na região que se caracterizam por concentrar uma grande quantidade de moradores de rua, a maioria dos quais pertencem ao Perfil 1, "o caído" (que constitui o morador de rua usuário de substâncias lícitas e/ou ilícitas; vide página 25). Em relação à vida de rua, os pontos centrais desse território são a Tenda (Espaço de Vivência Dom Luciano Mendes) e a Praça Fernando Costa. A Tenda constitui um espaço de convivência que possui um papel importante, já que nela se desenvolvem as novas referências de socialização que os recém-chegados à rua desenvolvem. É também um espaço de higiene pessoal. Nesse território encontram-se vários grupos de moradores de rua ou "malocas", cujos objetivos comuns são consumir substâncias lícitas e/ou ilícitas e catar materiais recicláveis. Os usuários comuns desse perímetro caracterizam-se pelo uso constante de substâncias lícitas e/ou ilícitas - nessa região. 
especificamente álcool e crack. Provavelmente por isso, ao fracionar-se o território conhecido como a Cracolândia, muitos usuários de drogas transladaram-se desse logradouro ao Parque Dom Pedro II, mesmo que a presença da Polícia Militar tenha sido intensificada em torno dos pontos mais concorridos na região.

O caráter comercial desse perímetro permite o desenvolvimento de várias estratégias de subsistência, relacionadas com a vida de rua. A principal atividade é a catação de materiais recicláveis, especificamente o papelão, seguida pela mendicância, o comércio informal e as doações de terceiros (Prefeitura ou ONG). Existem também "malocas" compostas por travestis e homossexuais no setor -por serem um grupo reduzido da população de rua, possuem uma linguagem particular, distinta dos outros grupos. Além da linguagem, o grupo se caracteriza por serem mais expressivos em relação a suas emoções e necessidades emocionais. 


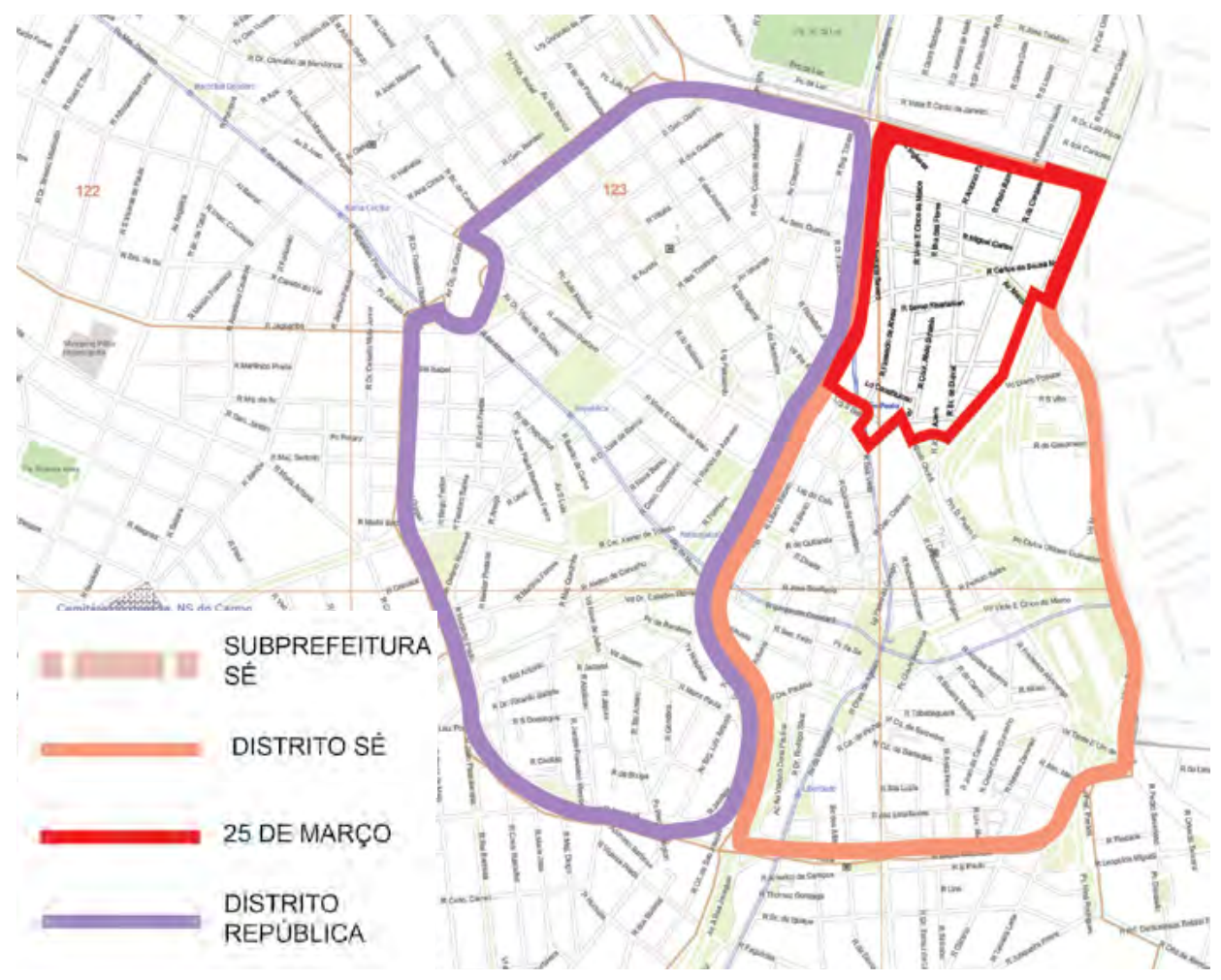

Mapa 13 - Perímetro 4

No Perímetro 4 em que se localiza a rua 25 de março, o caráter comercial permite que as estratégias de subsistência dos moradores de rua se relacionem com a catação de papelão e outros materiais relacionados com os pacotes de produtos, tais como plástico ou papel. O constante fluxo de pedestres na região permite desenvolver outras atividades relacionadas com a vida de rua como a mendicância e o furto. Perto do Mercado Municipal (Mercadão) e da Zona Cerealista, os moradores de rua oferecem seus serviços informais como carregar pacotes pesados. Na região existe a distribuição de sopão e doações de alimentos dos comerciantes do Mercadão.

A ausência de espaços públicos no perímetro, tais como parques ou praças, adicionada à constante movimentação noturna relacionada com a carga e descarga de mercadorias, faz com que sejam poucas as ruas-dormitório na região. 


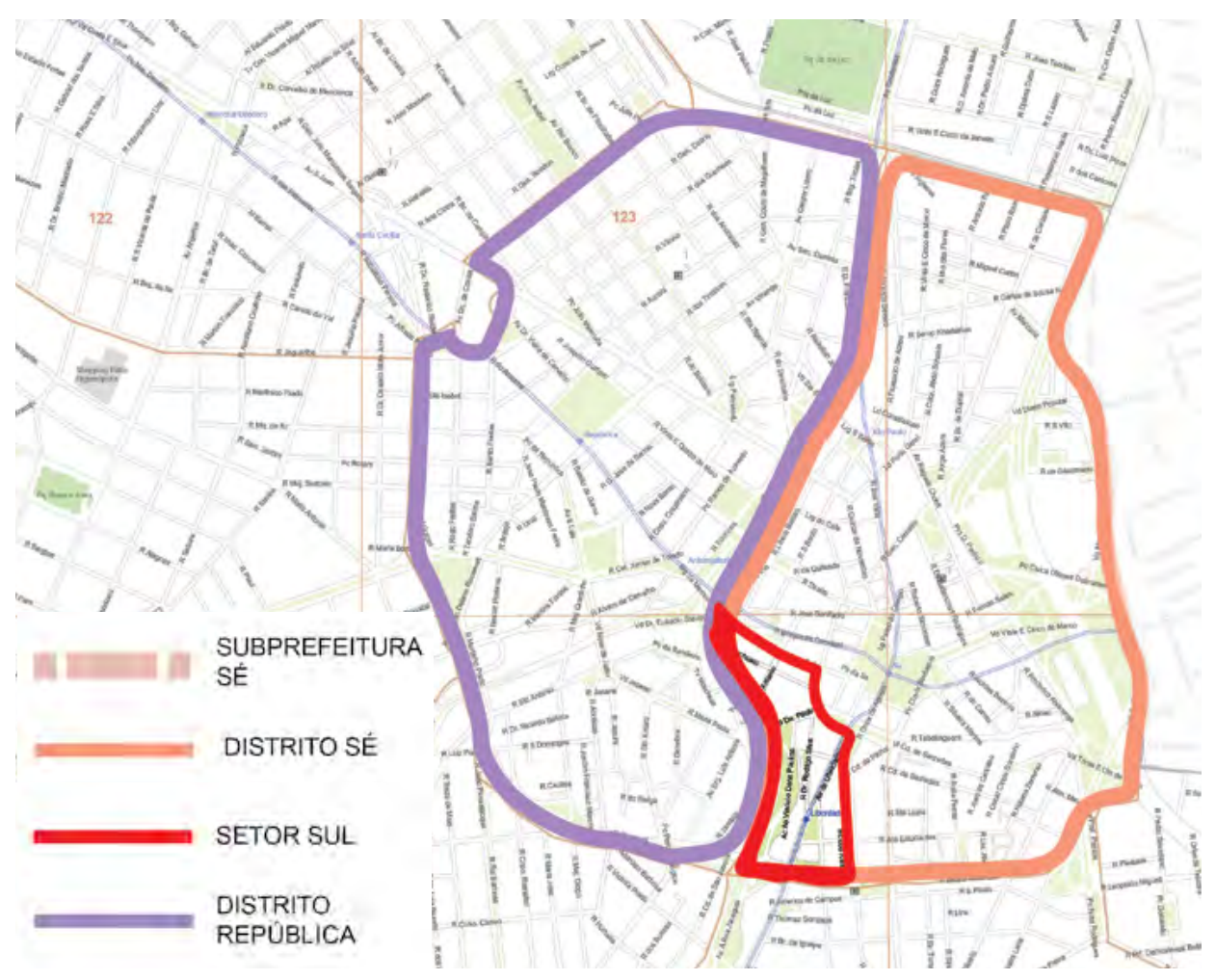

Mapa 14 - Perímetro 5

O Perímetro 5 se localiza na parte Sul do distrito, constitui uma peça complexa da região, pois articula o Distrito Sé com o Distrito Liberdade. Funcionalmente se relaciona muito mais ao último, em relação ao transporte e às atividades comerciais. Ao constituir um comércio especializado de mercadorias orientais, distingue-se dos outros perímetros comerciais no Distrito Sé. Entretanto, identificam-se moradores de rua que desenvolvem estratégias de sobrevivência similares às dos outros blocos no norte do distrito. 


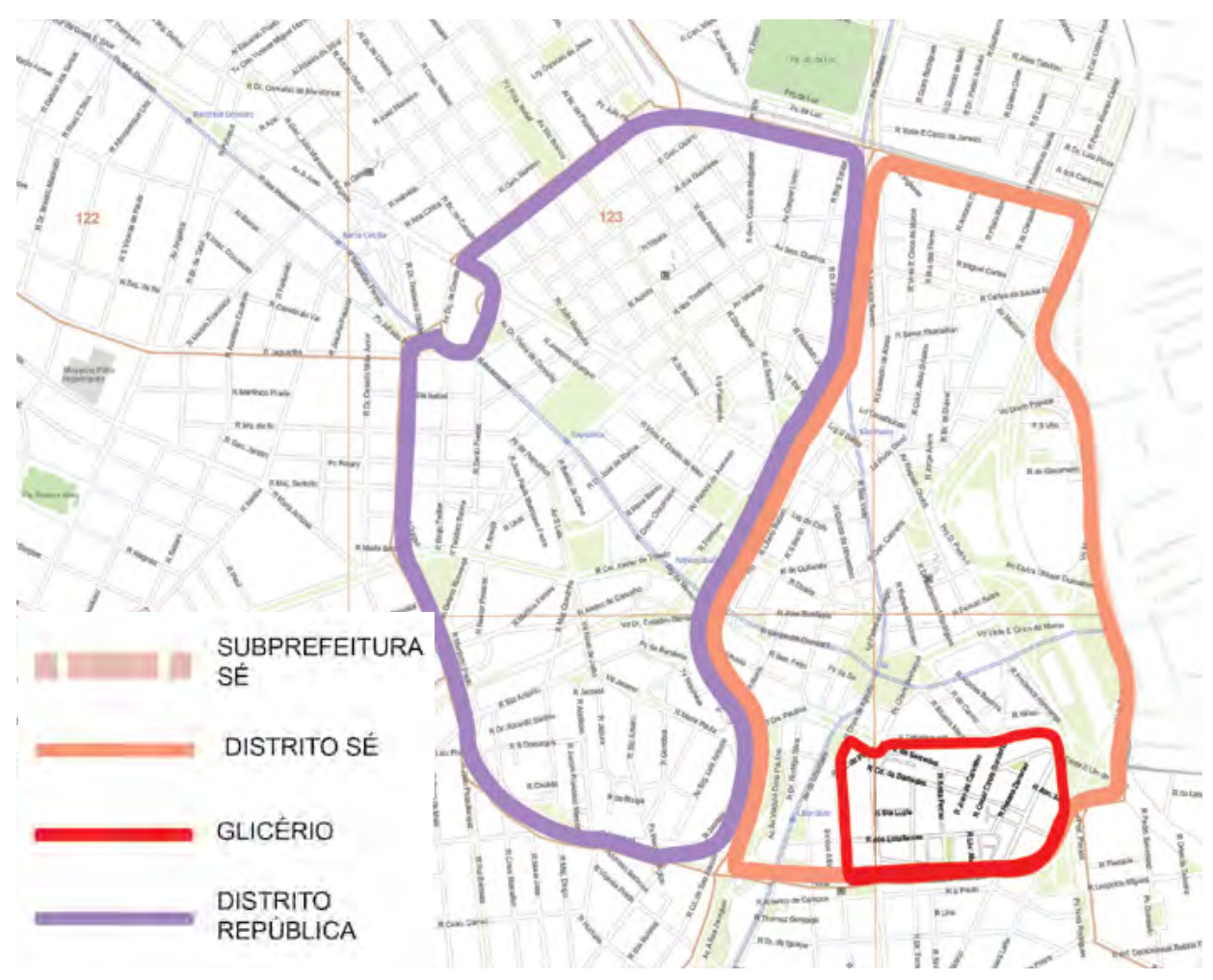

Mapa 15 - Perímetro 6

O Perímetro 6 caracteriza-se por ter como ponto central de convergência a instituição "Minha rua, minha vida", localizado perto da baixada do Glicério, no espaço embaixo do viaduto com o mesmo nome. Seu propósito principal é oferecer apoio à população de rua nas questões de alimentação, higiene pessoal e pernoite; para ter acesso a tudo isso, os usuários devem cadastrar-se. A instituição permite o trabalho voluntário dos moradores de rua, essa é uma estratégia dessa instituição para tentar reintroduzi-los à formalidade. Outra das vantagens nesse perímetro são os serviços de saúde (AMA, UBS e CAPS), mesmo que a população de rua não frequente constantemente esses serviços, já que os usuários apresentam múltiplas queixas em relação ao atendimento. 


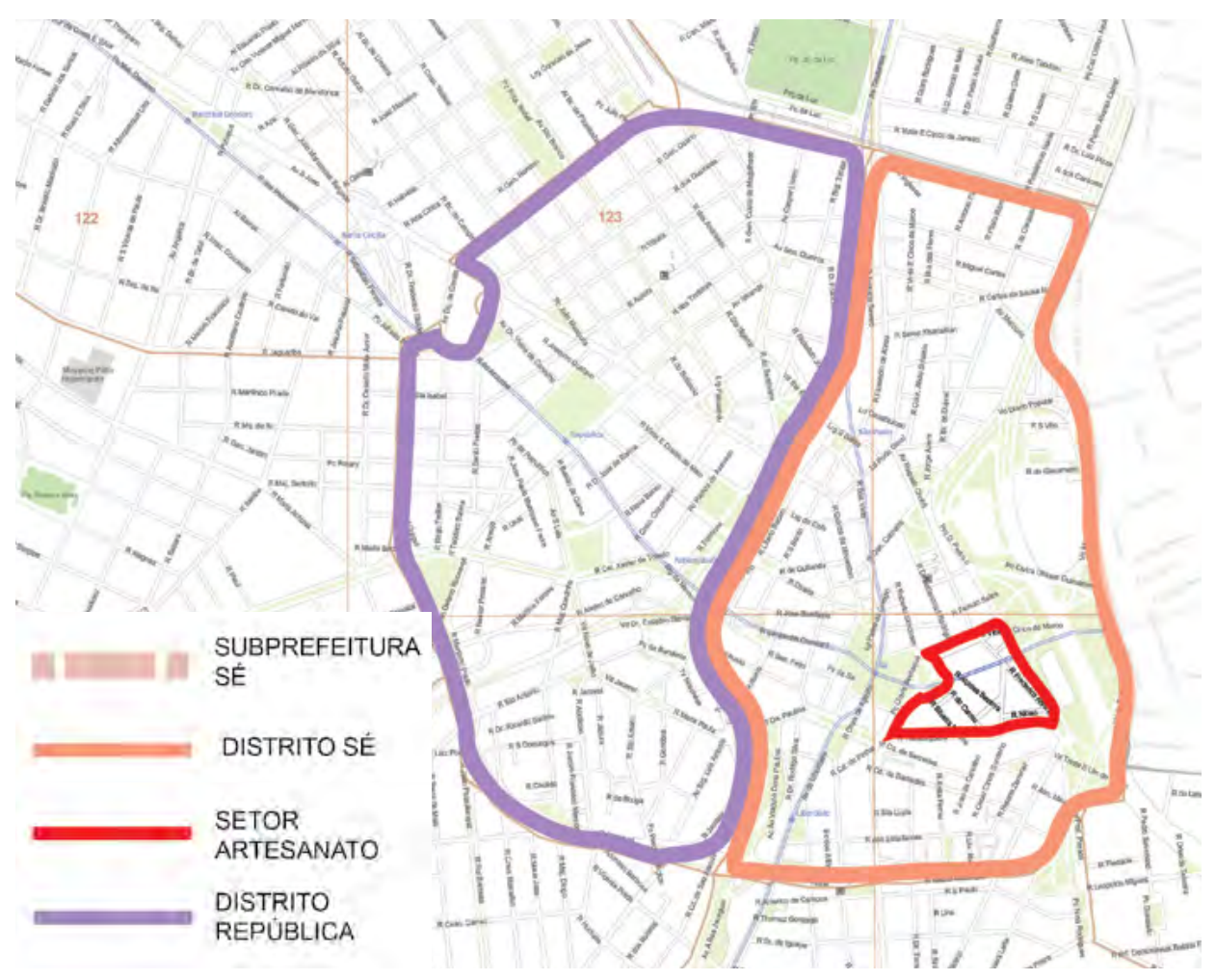

Mapa 16 - Perímetro 7

O Perímetro 7 pode considerar-se como um setor de artesanato, constitui outro dos blocos comerciais do Distrito Sé, o mais pequeno, e, por ser um área reduzida de comércio especializado, atrai uma clientela particular, que em sua maioria compra por "atacado". Nesse contexto se desenvolvem estratégias de subsistência similares às dos outros blocos comerciais, relacionadas com a catação de materiais de reciclagem.

Distingue-se o setor de artesanato pela escassa presença da população de rua; embora esteja nas proximidades de outras duas áreas caracterizadas pela concentração de moradores de rua, o setor não apresenta maior atrativo para essa população. O único foco em que se concentram os poucos moradores de rua é uma igreja católica no perímetro. Essa escolha se relaciona com a mendicância e apoio que recebem nesse logradouro especificamente. 


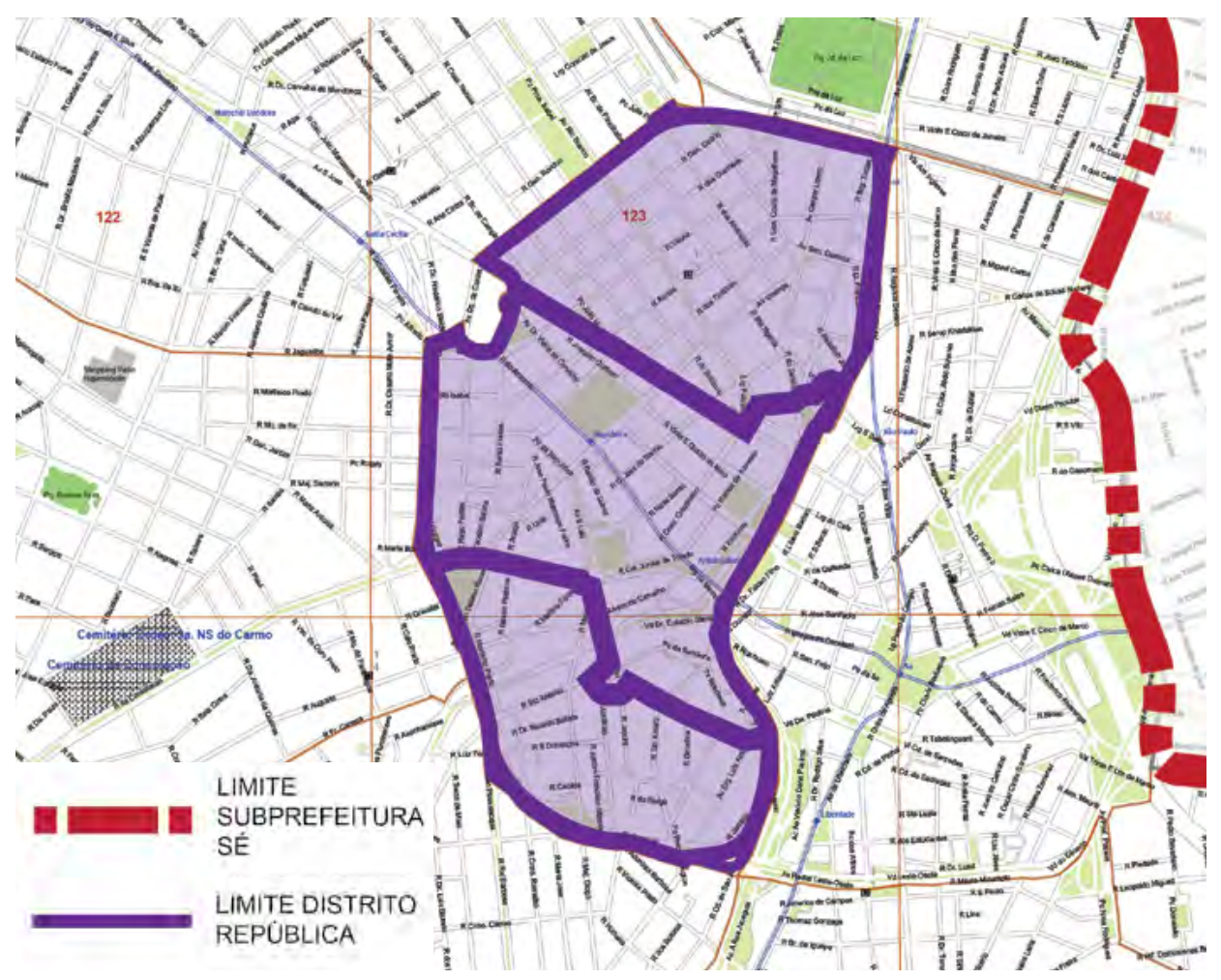

Mapa 17 - Distrito República e seus territórios menores

\subsubsection{DISTRITO REPÚBLICA}

Um dos dados interessantes do Mapa de Exclusão e Inclusão Social da Cidade de São Paulo (vide Mapa 2) é o destaque na área da República, em relação à grande quantidade de moradores de rua (adultos, adolescentes e crianças) concentrados nesse território. Isso indica que, na década de 1990, os moradores de rua desenvolveram estratégias de sobrevivência eficazes na área em questão, decorrente provavelmente de sua vocação comercial. Os dados que atraem a atenção do observador do Mapa são os pequenos grupos de população de rua fora do centro da cidade de São Paulo. Em bairros como Vila Maria, Socorro, Itaim Paulista e São Rafael, a população esteve composta por adolescentes e crianças em condição de rua, provavelmente relacionada com assentamentos precários (SEMPLA, 2002, p. 8 / SPOSATI, 1996, p. 68). 
No entorno dos espaços públicos desse distrito, especificamente na Praça da República e no Largo de Arouche, muitos moradores de rua passam o dia debaixo das árvores. A Praça General Craveiro Lopes é outro espaço público onde se congrega o povo de rua; os grupos identificados pelos atendentes da prefeitura consolidaram-se recentemente. O perímetro se caracteriza por estar ocupado por moradores de rua de condição crônica, uma população composta por várias etnias, caracterizada pelo consumo excessivo de álcool. Identifica-se também nesse perímetro o consumo de substâncias lícitas e ilícitas em parte da população de rua moradora nesse local. 


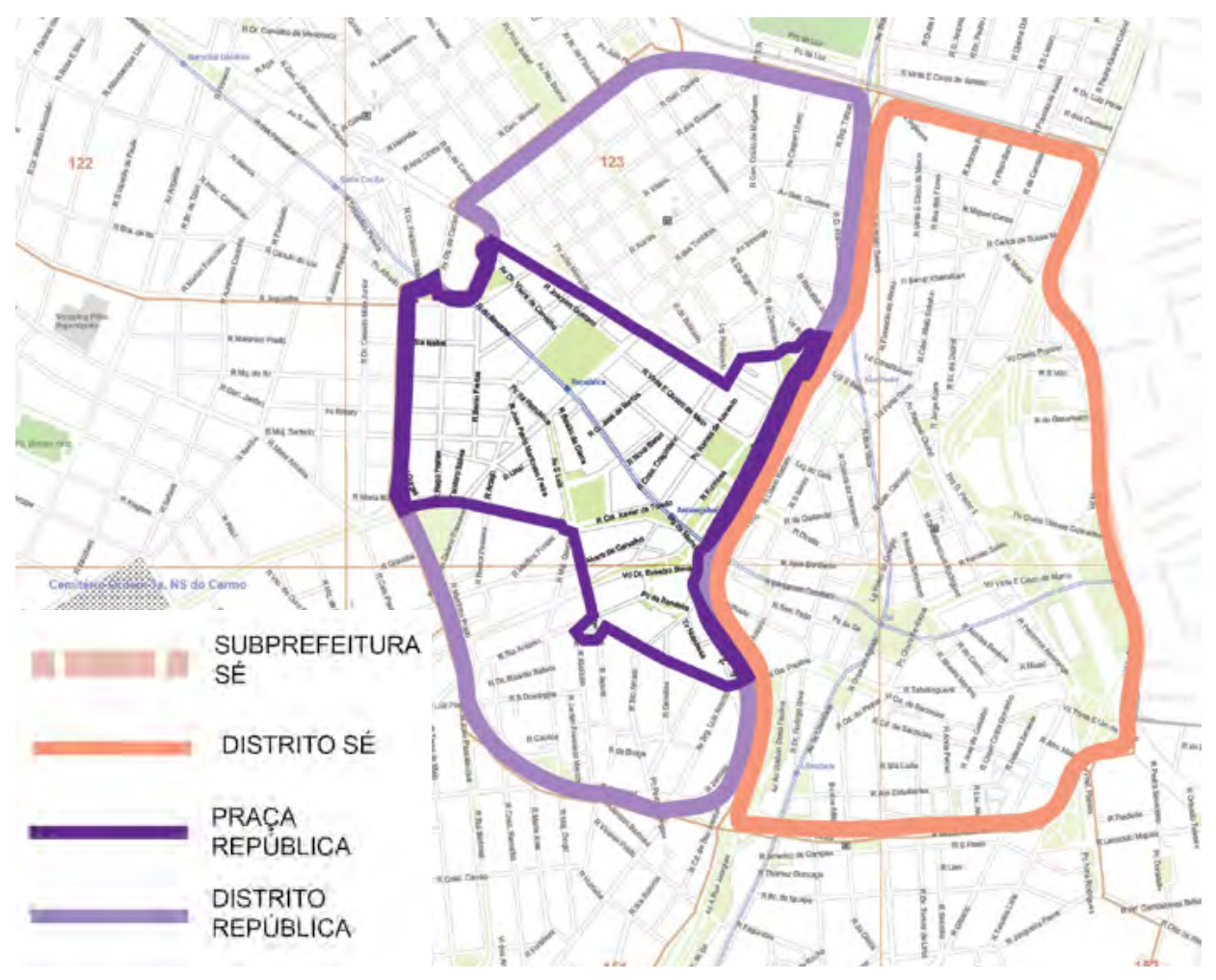

Mapa 18 - Perímetro 8

Os moradores de rua queixam-se de agressões por parte das autoridades locais na região. Durante o dia, o perímetro 8 apresenta poucos espaços públicos onde se concentram os moradores de rua; de noite se identificam locais de pernoite dispersos, especificamente ruas-dormitório. Muitos dos moradores de rua que ocupam os espaços da região há tempo conhecem as dinâmicas comerciais do setor e as aproveitam para subsistir. O Viaduto Minhocão constitui uma infraestrutura longa, transversal aos Bairros República, Santa Cecília e Barra Funda. Ao longo dos três bairros, identificam-se moradores de rua com refúgios improvisados ou estruturas mais elaboradas (SANTOS, 2005, p. 225).

Entre os territórios menores que formam a peça da "Praça da República", o Vale de Anhangabaú possui uma dinâmica particular. Topograficamente constitui 
uma depressão na região, por isso os espaços públicos que o formam assumem um outro caráter, próprio para congregar grupos diversos de pessoas. Durante o dia, é um espaço com uma circulação fluida de pedestres, em sua maioria usuários do transporte público, especificamente pela variedade de modalidades de transporte: a Estação de Metrô Anhangabaú, o Largo do Paissandu e a Praça do Correio. Os dois espaços públicos que limitam o Vale de Anhangabaú, a Praça Ramos e a Praça do Correio, têm dinâmicas distintas. Segundo os relatórios dos monitores da Prefeitura, enquanto a primeira é conhecida como um ponto de tráfico de drogas, na segunda identificam-se muitos usuários de crack.

Nesse logradouro da cidade se congregam muitas crianças e adolescentes, a maioria em condição de rua, seja para convivência, praticar algum esporte (seja futebol ou skateboarding) ou para consumir sustâncias ilícitas. Em algumas partes do Vale se identificam alguns adultos e idosos em condição de rua, especificamente perto da Praça do Correio; em sua maioria se caracterizam pelo consumo de álcool, mas existem alguns casos de dependência química. 


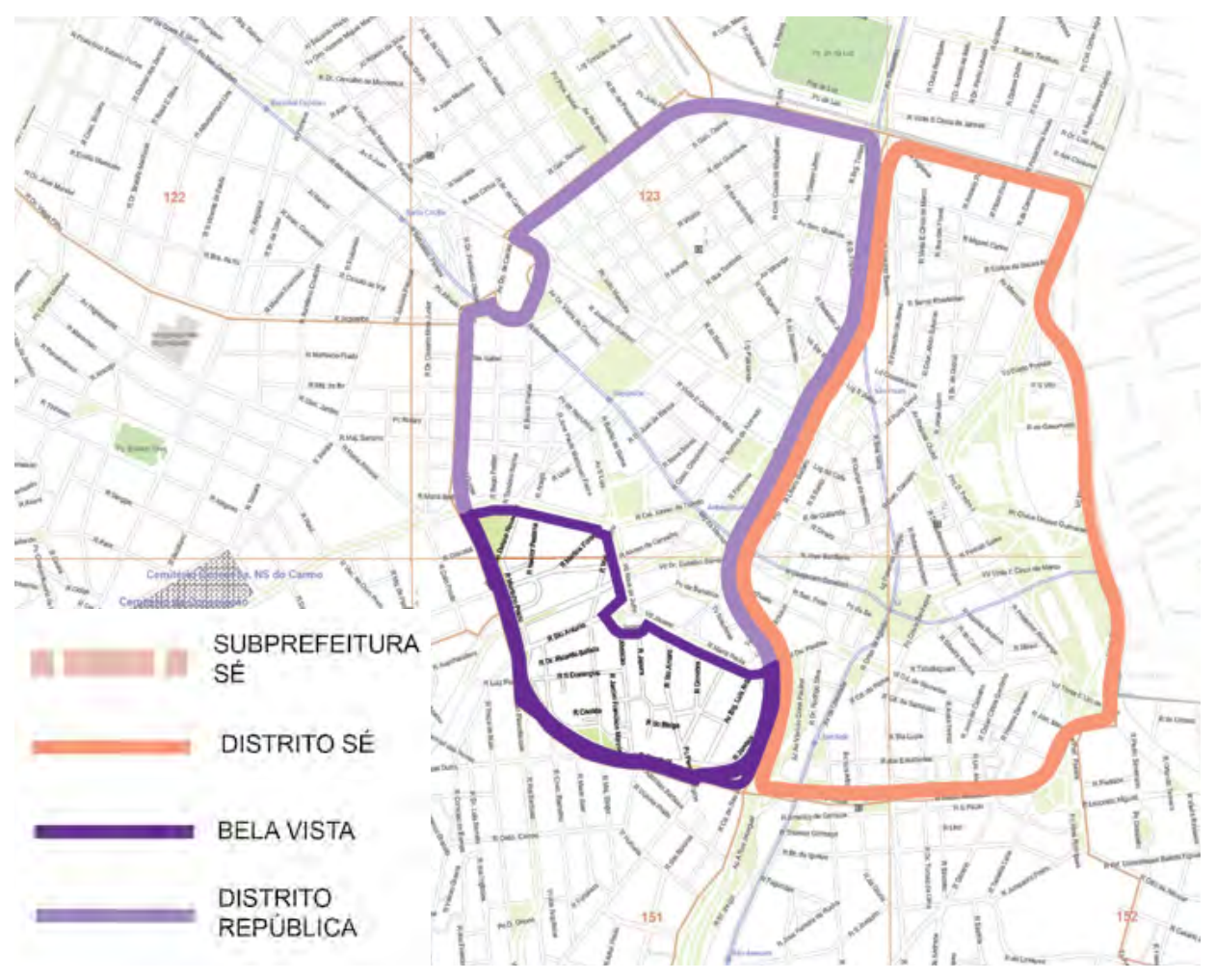

Mapa 19 - Perímetro 9

No Perímetro 9 identificam-se poucas concentrações de moradores de rua nas praças ou largos, e a área se caracteriza primordialmente pela ocupação dispersa. Em sua maioria são grupos que se reúnem nas ruas para dormir. Os ocupantes desse perímetro apresentam certo grau de permanência: identificaram-se uns moradores com cerca de seis anos no mesmo logradouro. É comum encontrar-se pessoas em condição de rua isoladas. Aquelas que não pertencem a grupo nenhum apresentam mais receio no momento de serem abordados pelos trabalhadores sociais na região. É fácil obter pratos de comida dos restaurantes na região, pois fornecem almoço como doação aos moradores de rua.

A rua Aguiar de Barros é um logradouro conhecido, ponto de encontro para cozinhar e descansar dos moradores de rua. Outras ruas, como a Major Diogo, concentram à 
noite homens de idade produtiva, especificamente nos espaços embaixo dos viadutos; no caso do viaduto Jaceguai, congregam também homens durante o dia. Existem ruas como a Japurá, onde os indivíduos sós pernoitam; pode-se encontrar nelas dois ou três moradores de rua dispersos, o que ratifica que nesse perímetro nem todas as ruas-dormitório apresentam presença de grupos. 


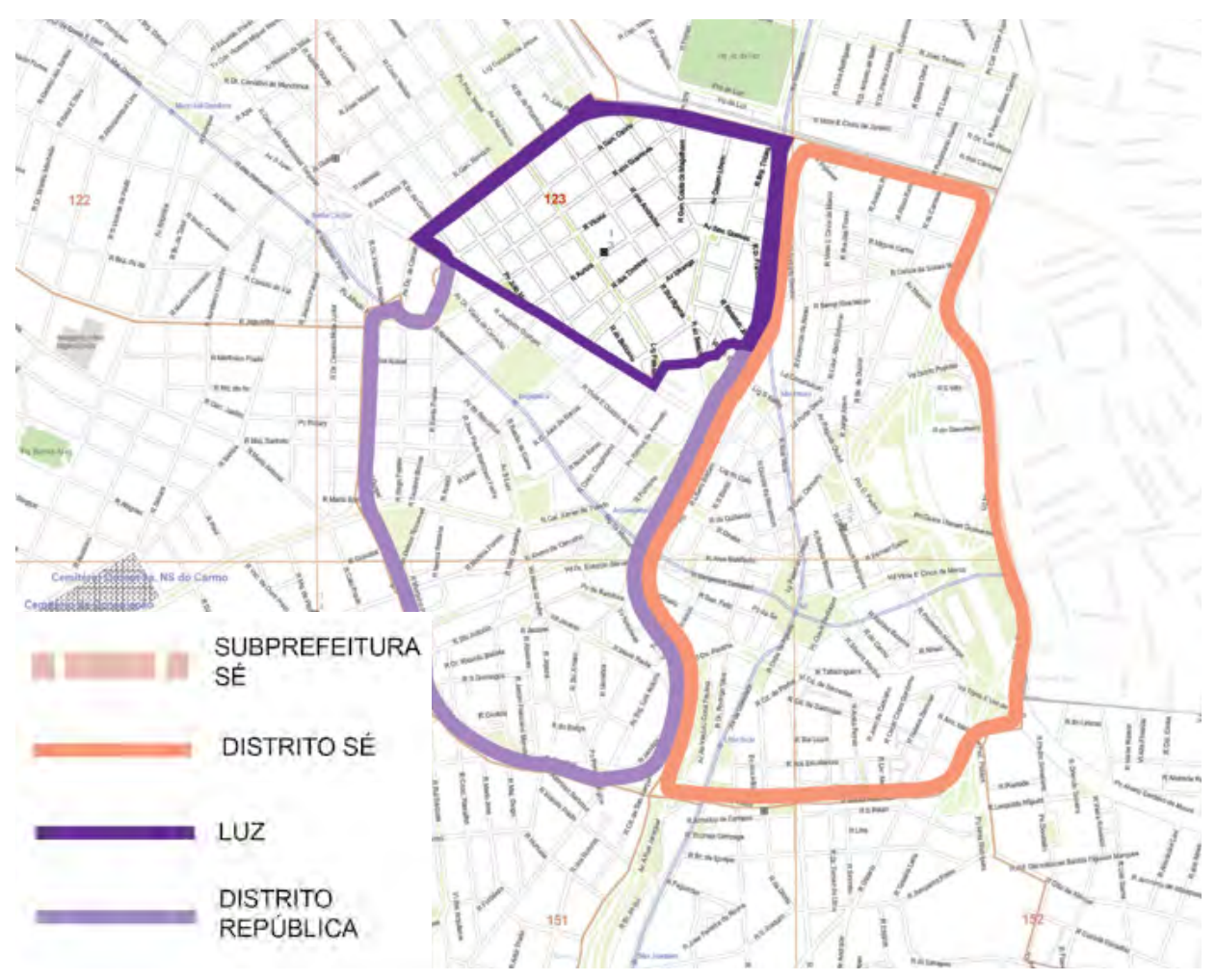

Mapa 20 - Perímetro 10

No Perímetro 10 se localiza parte da área de influência de um dos territórios mais enigmáticos do imaginário da cidade, o chamado Cracolândia. Essa região que constitui parte do bairro Bom Retiro, recebeu tal nome por ter sido ocupado por mais de uma década por moradores de rua dependentes de substâncias químicas. Embora a maior parte da Cracolândia se localize em um outro bairro, a área de influencia desse território extravasa os limites administrativos, o que tem repercussões nos bairros vizinhos como é o caso do bairro República.

A introdução do crack na década de 1990 mudou a vida na rua em muitos países; por ser uma substância mais acessível, cujos efeitos são mais imediatos, adaptou-se à necessidade daqueles que queriam escapar da realidade. Existem no Brasil muitas cracolândias, localizadas em distintas cidades; são setores que, apesar de poucos 
explorados por pesquisadores, são conhecidos pela população em geral. No caso específico de São Paulo, a Cracolândia não se espraia em todo o perímetro da peça Luz; é, na verdade, mais reduzido que o imaginado por muitos. Funcionalmente se relaciona mais com o perímetro de Campos Elíseos, localizado fora da Subprefeitura Sé.

A cracolândia se caracteriza pela ocupação de moradores de rua que pertencem ao Perfil 1 ("dependente" ou "caído"), o que quer dizer que em sua maioria o grupo se constitui por pessoas dependentes de substâncias ilegais, mais especificamente do crack. O território também se caracteriza pela presença de moradores de rua cuja estratégia de sobrevivência se baseia em trabalhossombra, seja prostituição, seja roubo, seja venda de substâncias ilícitas.

A história dessa área da cidade está ligada à do crack, substancia ilícita que se populariza na década de 1990 e cujo consumo se estende rapidamente devido ao baixo custo de fabricação e aos efeitos eficazes. Consequentemente, no decênio de 2000 a 2010, à medida que o consumo do crack cresce, a ocupação do território se consolida. Em janeiro de 2012, inicia-se a Operação Luz, seu objetivo foi desarticular a rede de tráfico e consumo de drogas instalados na Cracolândia. No fim desse mês, relata-se a constituição de "pequenas cracolândias" visto que, ao se desarticular a área, formaram-se outros núcleos de moradores de rua com problemas de dependência e vendedores de droga. Em outras palavras, as atividades concentradas no Bairro República espraiaram-se a outros bairros do centro da cidade. Os vizinhos começaram a perceber essas pequenas cracolândias em Santa Cecília e Barra Funda, por exemplo. 


\subsection{OS DESLOCAMENTOS DOS MORADORES DERUA}

Dependendo da cidade, as estimativas desenvolvidas sobre a população de rua sistematicamente variam, logo pode-se afirmar que as contagens têm sido até hoje um empreendimento inexato. Essas variações se devem aos padrões de vida irregulares da população de rua; apesar disso, recorrer às contagens foi o caminho seguido por muitos pesquisadores. No momento em que se iniciam as contagens sistemáticas de moradores de rua na cidade de São Paulo (1991), começou-se a conhecer tanto o número de pessoas que ocupavam as ruas, quanto a natureza de seu deslocamento: "além de considerar os desafios impostos pela mobilidade, foi importante antecipar especificidades para o contato com essas pessoas, na rua ou em instituições". O caráter flutuante de uma porção da população de rua faz com que os censos não tenham total exatidão, pois indivíduos entram e saem da rua a todo momento, por diferentes motivos (QUIROGA / RODRIGUEZ -org-, 2009, p. 18).

Deixando a exatidão de lado, as contagens permitiram identificar os territórios ocupados pelos moradores de rua; as variações, ora crescendo ora diminuindo, assinalaram as áreas críticas da cidade. Os conhecimentos obtidos sobre a população de rua, baseados nos censos consecutivos (1991-2011), também fizeram com que os pesquisadores questionassem as conclusões dos estudos do século passado: "the hobo is, to be sure, always on the move, but he has no destinations, and naturally he never arrives . (...) "He has gain his freedom, but he has lost his direction"5 (PARK, 1952, p. 93).

5. Tradução livre: "O vagabundo está, com certeza, sempre se deslocando, mas ele não tem destinos, e naturalmente ele nunca chega. (...) Ele ganhou sua liberdade, mas perdeu a sua orientação". 
Os deslocamentos dos moradores de rua não se limitam ao físico: "[eles] (...) se deslocam não só geograficamente, mas também econômica e socialmente, por isso torna-se difícil precisar o número de pessoas que se encontram nas ruas da cidade". Esses conhecimentos, obtidos nos primeiros censos da cidade, foram valiosos, porque assinalaram a complexidade da vida na rua, pois as pessoas em condição de rua são errantes em mais de um sentido (VIEIRA / BEZERRA / ROSA, 1992, p. 48).

A mobilidade da população de rua se desenvolve em vários níveis: espacial, social, econômica, pessoal, física e emocionalmente. Adicionado a isso, assinala-se que a vida na rua apresenta alternativas diferenciadas de relações sociais, abrigo e trabalho. Ao se pesquisar a população de rua, precisa-se propor uma metodologia própria, que capture seus diferentes deslocamentos. Em relação aos deslocamentos dos moradores de rua, sabe-se que "they are moved to act by individual purposes, but in doing so they realize a common end" e que "their impulses are private, but actions are public". A revisão bibliográfica e as observações de campo permitiram conhecer os diferentes aspetos dos deslocamentos que os moradores de rua desenvolvem na cidade de São Paulo., por isso, pode-se afirmar que eles constituem, em sua maioria, ações voluntárias. Os deslocamentos dos moradores de rua possuem uma motivação individual. Produzidos por motivações pessoais, são deslocamentos pouco pesquisados por serem originados por decisões individuais, sua lógica escapa aos pesquisadores (PARK, 1952, p. 93).

6. Tradução livre: "Eles são movidos a agir por propósitos individuais, mas, ao fazê-lo, eles realizam um fim comum".

7. Tradução livre: "Seus impulsos são privados, mas suas ações são públicas". 
Muitos pesquisadores consideram os moradores de rua como os "neonômades"; para eles, "o homem de rua vive uma contínua peregrinação nômade pela cidade". São considerados nômades porque, diversamente do resto da população em geral, eles carecem de um espaço de moradia fixa, não têm um lugar próprio e carregam seu suporte vital consigo (RABINOVICH/TACHNER, 1998, p. 10).

Na sua maioria, os deslocamentos se desenvolvem dentro de um mesmo bairro (curtos), uns sendo motivados pela mudança no consumo de substâncias lícitas e ilícitas. Mas, ao mudar o consumo de uma substância ilícita por outra, a localização do usuário muda, o que indica que existe uma relação entre o que se consome e o território ocupado. Quando existe uma mudança no consumo de substância, existe uma mudança de local; à medida que o indivíduo aprofunda sua exploração de substâncias na rua, vai conhecendo as redes e esquemas desse contexto. Esse deslocamento tem relação com o comportamento grupal, pois, ao se deslocar, deixa-se um grupo para aderir-se a um outro, de acordo com a substância consumida. Atualmente, os observadores do fenômeno de rua na cidade identificam a travessia dos jovens de uma substância a outra, que pode começar com maconha no Vale de Anhangabaú e terminar com crack na Cracolândia ou na região da Luz. Por enquanto o jovem vai de um grupo a outro, por períodos variáveis de tempo, realizando pequenos furtos e prostituição para sobreviver. É importante assinalar que os moradores de rua que são usuários de substâncias e os que não são usuários raramente se misturam. O que quer dizer que esse comportamento grupal se estende aos hábitos e preferências pessoais do dia a dia. Isso coloca a ideia da pirâmide social na rua, pois os usuários de drogas são vistos nesse contexto como aqueles que pertencem à base da pirâmide. Outro dos 
motivos pessoais dos moradores de rua para se deslocarem se relaciona com as estratégias de sobrevivência que desenvolvem. Nesse sentido, os jovens apresentam deslocamentos mais frequentes, pois possuem a vantagem de uma boa condição física; no caso específico do furto, eles marcam o território onde "trabalham" e onde se reúnem com seu "grupo" para fins de convivência social. Todos os dias, em um perímetro relativamente pequeno (um bairro), eles roubam em uma locação e se reúnem em outra; as observações de campo assinalam o Vale de Anhangabaú como um ponto de encontro dos jovens após furtar ou simplesmente para consumir maconha. Por seu lado, os adultos apresentam padrões mais sedentários, relacionados com a estratégia de sobrevivência, pois eles ficam em uma locação por mais tempo para desenvolver uma estratégia em particular; mas, em se fazendo necessário, mudarão de locação a fim de obter maiores ganhos. Mais um dos motivos pessoais para se deslocar é a procura de assistência social. A variedade de assistência dirigida a essa população, concentrada no centro da cidade, permite que os moradores de rua possam escolher o que precisam e onde vão para consegui-lo. Por isso, alguns logradouros do centro registram maiores concentrações de moradores de rua, por exemplo o Largo de São Francisco.

Os deslocamentos dos moradores de rua se relacionam às condições sociais do indivíduo, parece combinar tanto um deslocamento de local, quanto de classe social. Existe uma contradição inferente, pois mesmo que eles se deslocam fisicamente, socialmente eles permanecem na mesma condição. Na população de rua, pode-se encontrar indivíduos que por diversos motivos moram na rua, e o contexto social parece ter uma forte influência nessa decisão. Um dos deslocamentos mais comuns é o de residência, pois todos os dias pessoas entram e saem da rua, mesmo que trabalhem: 
"a impossibilidade de poder desfrutar de uma moradia é o que, no fundo, conduz todo o indivíduo a ir procurar o abrigo da rua" (SIMÕES, 1992, p. 37).

A tendência das classes baixas morarem na periferia e das altas morarem no centro mudou nas últimas três décadas; o centro e outras áreas da cidade menos valorizadas tonaram-se os territórios onde se encontra uma opção mais acessível e com mais possibilidades de sobrevivência. Ao subirem os preços das moradias na periferia, pela melhora dos serviços e equipamento, o local se torna inviável para a população de baixa renda, cuja renda diminuiu ainda mais. Com a melhoria do ambiente nas periferias, o centro da cidade foi abandonado por pessoas de maior poder aquisitivo. Isso facilitou a sua ocupação por parte de pessoas que procuravam abrigo na cidade: "como resultado, muitos moradores pobres tiveram de colocar de lado o sonho da casa própria e cada vez mais optar por viver em favelas ou em cortiços, que aumentaram substancialmente". Os padrões de vida mudaram na cidade de São Paulo; há algumas décadas, os cortiços eram considerados como o padrão mais vil de moradia. Nas décadas de 80 e 90, a pobreza fez com que as vagas nas favelas ficassem muito disputadas; aqueles que não conseguiam lugar passavam a procurar nos cortiços do centro da cidade uma vaga de acordo com sua renda. O crescimento dos custos fez com que aqueles que não conseguiam morar nem em favelas, nem em cortiços, fossem para a rua, procurando refúgio nos locais públicos da cidade (PIRES, 2003, p. 231).

$\mathrm{Na}$ escala de informalidade, entre o cortiço e a rua, existe ainda uma série de opções. Do cortiço se passa à pensão, que, "apesar da precariedade, oferece um mínimo de 
privacidade, mas supõe necessariamente a existência de recursos financeiros". Outra opção similar são os alojamentos de trabalho onde se procuram vagas de caráter temporário. São comuns na construção civil e nos depósitos de papelão dos catadores de lixo; suas condições são insalubres, e não possuem móveis ou equipamento para moradia. Os alojamentos de trabalho reforçam a relação trabalho-moradia. Quando a pessoa não tem emprego e não há renda nem mais para o pagamento de uma pensão, ela passa aos albergues, privados ou públicos. Entre a pensão e a rua, "restam como alternativas os alojamentos não pagos, os albergues, especialmente a CETREM" (VIEIRA / BEZERRA / ROSA, 1992, p. 80).

A rua é a última opção; mesmo que no início seja uma inserção individual, existem grupos de companheiros de trabalho ou de aventura que oferecem certo apoio nessa situação. Outra é a situação das famílias que entram na vida de rua, pois ao inserirse como um grupo constituem sua própria rede de apoio. Pode-se afirmar que esse caminho tem duas vias, pois quando o morador de rua procura a reinserção, ele procurará sair da rua mesmo que seja gradativamente. Essa travessia individual ou grupal varia em relação ao tempo de permanência. Às vezes constituem movimentos coletivos, já que são núcleos familiares os que se deslocam na rua. Pouco se sabe das famílias que moram na rua. Para muitos é uma condição temporária; por recusaremse $\mathrm{a}$ ir aos albergues, procuram nichos na cidade para permanecer juntos, mesmo que seja na rua. Às vezes se registram prédios abandonados, os quais são ocupados por uma o mais famílias. Alguns moradores de rua preferem ficar juntos nessas

8. Centro de Terapia e Reabilitação Integrada Municipal. 
circunstâncias precárias e não dispersar o núcleo familiar nas instituições sociais que oferecem abrigo. Esses grupos de moradores de rua podem fazer deslocamentos longos, pois visitam famílias ou amigos que oferecem abrigo temporário. A expulsão é um tipo de deslocamento comum para os moradores de rua, pois desde a antiguidade registram-se as práticas de segregação nas cidades. É importante assinalar que essas ações, que têm como fim o deslocamento dos moradores de rua, vêm de diferentes atores da cidade e constituem uma prática comum até hoje. Propõe-se dividi-las no exílio praticado dentro da comunidade de rua e nas práticas de terceiros.

O exílio é uma prática comum dentro do povo de rua. Pode afirmar-se que dentro da população de rua a convivência em grupos ou malocas é essencial, por isso é comum que um ou vários indivíduos sejam expulsos do grupo por práticas que não concordem com os interesses ou objetivos da maioria. Essas expulsões implicam uma mudança de localização; o grau do desacordo com o grupo pode determinar a magnitude do deslocamento; seja este curto ou longo, o indivíduo confronta novas circunstâncias que às vezes implicam mudança nas estratégias de sobrevivência. Constitui uma prática interna, da qual há poucos dados. As práticas de expulsão impulsionadas por terceiros (por pessoas fora do povo de rua) são muito mais complexas e variadas. Esses deslocamentos podem ser impulsionados pela sociedade civil ou pelas autoridades, o importante deles é que são provocados por atores fora da população de rua. As ações para afastar os moradores de rua de certas áreas se concretizam por meio de infraestrutura adicionada às construções formais, conhecida como "arquitetura antimendigo". Oficialmente essas infraestruturas são motivadas pela segurança dos prédios, mas na realidade se procura eliminar qualquer espaço em que possam 
pernoitar os moradores de rua. As expressões dessa prática variam, mas o elemento mais comum nelas são as grades, que podem ser observadas em prédios e espaços públicos e privados. A ação dos moradores de rua não passa despercebida; muitos vizinhos reagem diferentemente ante a presença deles: "constituem-se em alvo de expulsões forçadas, gerando hostilidades, produzindo um fenômeno descrito pelos americanos como síndrome de NIMBY [not in my backyard, cuja tradução em português corresponde a 'não no meu quintal']". Essa síndrome se repete em muitas cidades, pode-se dizer que o NIMBY "designa as práticas de estigmatização contra a população em situação de rua em sua dimensão espacial (...) essas práticas trazem complexos desdobramentos sobre as dinâmicas de valorização do solo urbano" (QUIROGA / RODRIGUEZ -org-, 2009, p. 140).

Essa prática organizada não se foca unicamente nos moradores de rua, pois as instituições de assistência social que têm projetos para implementar auxílio a essa população experimentam rejeição nas comunidades. Considera-se uma expressão da incompatibilidade das práticas urbanas, pois a população de uma região age a fim de "proteger" seu investimento (SANTOS: 2005, p. 226).

A rejeição experimentada pelos moradores de rua não se limita a protestos de vizinhos, pois as ações criminosas contra essa população são comuns. Registram-se vários crimes contra os moradores de rua; essas ações indicam tanto o agir de criminosos, quanto os níveis em que se desenvolve a discriminação e as práticas revanchistas contra o povo de rua. Uma das primeiras políticas de assistência social em relação aos moradores de rua - pagar a passagem de volta para a cidade natal do indivíduo - 
data do começo do século XX e era comum nas cidades norte-americanas. Essa política de expulsão continua até hoje, pois no Brasil se registram ações similares. Segundo os relatórios de alguns assistentes sociais, certas manhãs da semana, acompanhados por policiais, vão aos espaços da cidade onde se concentram os moradores de rua para encaminhá-los para fora da cidade com o transporte previsto pelo setor público. Cidades como Campinas implementaram esse tipo de ações integradas impulsionadas pelo governo local (PMC, 2010)

O interesse na renovação das cidades, causado por eventos esportivos ou culturais, produz grandes empreendimentos urbanos; uma das suas consequências imprevistas é a expulsão da população em situação de rua. A expulsão é gerada por causa das estratégias de renegação urbana nos espaços públicos e privados, cujo objetivo principal é a requalificação do solo em áreas centrais. As cidades se tornam punitivas, valorizando a lógica do mercado como a única solução das problemáticas urbanas, logo as transformações dos espaços não levam em conta os interesses de todos cidadãos e favorecem a poucos. Sendo a ideia dessas intervenções atrair mais investimentos, procura-se criar uma imagem positiva e limpa da cidade por meio de projetos urbanos, porém tenta-se ocultar essas "desvantagens" ou "fraquezas", estabelecendo um controle das populações marginais. Essas práticas higienistas e punitivas não são novidade, mas hoje é evidente que a infraestrutura pública e privada se encarrega de afastar os moradores de rua dos espaços, através de grades e paredes, expressões da arquitetura antimendigo em maior escala. Muitos pesquisadores nomeiam-nas como "práticas da cidade revanchista", relacionando-as com repressão e restrição da locomoção. Essaspráticasgeramnovoselementosurbanosquefomentamasegregação 
social: "enclaves fortificados". Os espaços na cidade são paulatinamente privatizados, fechados e monitorados. Todo consumo, lazer, trabalho e moradia é vigiado: "Esses novos espaços atraem aqueles que estão abandonando a esfera pública tradicional das ruas para os pobres, os 'marginalizados' e os sem-teto" (PIRES, 2003, p. 211).

Registram-se constantemente queixas dos moradores de rua em relação às autoridades policiais, especificamente a Guarda Civil Metropolitana na cidade de São Paulo. O papel esperado desses agentes é a proteção da população em geral, mas para os moradores de rua eles representam um dos motivos para se deslocar, pois os colocam em constante movimento, exemplo disso são as expulsões continuas de logradouros a onde os moradores de rua se concentram regularmente (SERRANO, 2004, p. 32 / CGGDH, 2012).

Às vezes humilhação e abuso de poder acontecem nos albergues, o que faz com que os moradores de rua se afastem de certas instituições e se dirijam a outras (VIVA O CENTRO, 2004, p. 3).

\subsubsection{DESLOCAMENTOS TERRITORIAIS}

Esse tipo de deslocamento dos moradores de rua se foca no território em que se desenvolvem suas ações. Em relação ao urbanismo, este é o tipo de deslocamento que mais atrai o interesse dos pesquisadores, pois, mesmo que as suas motivações variem, o importante é o relacionamento do indivíduo com o território. Os moradores de rua se relacionam com o território de diferentes maneiras, já que para uns em contexto de rua 
a área na que desenvolvem suas ações se limita e para outros essa área se amplia. Estabelecem-se duas escalas referentes aos deslocamentos territoriais. Por constituir parte de uma subcultura, nem sempre essas escalas se relacionam com os limites administrativos da cidade como bairro, distrito, subprefeitura, cidade, etc. Os deslocamentos territoriais dos moradores de rua se relacionam com os limites imaginários dentro da cidade, no contexto do imaginário coletivo da vida de rua. Relacionam-se com as funções urbanas da cidade de São Paulo, o que faz com que para eles as escalas e territórios variem de acordo com o seu perfil individual.

Esses territórios têm relação com o imaginário coletivo na cidade. Nessa população, embora constituam uma subcultura em particular, apresentam-se espaços comuns com o imaginário coletivo do resto da população. O agir do morador de rua na cidade nos assinala a criação de pequenos territórios, alguns não percebidos pelo usuário comum. Esses novos territórios podem ser o ponto de início ou o destino de muitos dos seus deslocamentos. Os deslocamentos dentro de um bairro, também chamados de curtos e limitados, são considerados os mais comuns entre os moradores de rua. Motivados pelo instinto de sobrevivência, deslocam-se de um lugar a outro com seus pertences, mas permanecem no mesmo bairro. Os motivos são vários: proteção pessoal, a procura de um lugar calmo para dormir (de dia ou de noite), a fome, a necessidade de materiais para construir um refúgio, etc. Para os censos, "o primeiro problema metodológico relevante refere-se à ausência de residência fixa convencional e à elevada mobilidade desta população nos espaços urbanos". Por isso, a mobilidade que caracteriza a população de rua constitui um dos desafios nas contagens e pesquisas. Sua mobilidade física permite-lhe variar os modelos de 
sobrevivência na cidade de São Paulo, em concordância com a temporada e sua capacidade mental ou física. O deslocado vive com uma incerteza permanente, pois não sabe onde vai pernoitar ou como vai subsistir (QUIROGA / RODRIGUEZ -org-, 2009, p. 21).

As circunstâncias particulares desses indivíduos podem variar, pois não todos estão na mesma condição física e mental. Por exemplo os catadores de lixo realizam deslocamentos diários de um ponto a outro da cidade, a fim de trasladar os materiais catados aos pontos de venda e se auxiliam de uma carroça ou um carrinho. Nem sempre os catadores de lixo possuem um veiculo para se auxiliar, mesmo assim eles conseguem trasladar os materiais catados seja para venda ou para construir refúgios. Nesse sentido, esses deslocamentos podem sem classificados como curtos e regulares, mas deve assinalar-se que nem todos os catadores de lixo são moradores de rua, logo são circunstâncias de uma minoria dos moradores de rua em São Paulo.

Este tipo de deslocamento se relaciona com uma das estratégias de subsistência dos moradores de rua, mas diferentemente das outras, esta atividade implica deslocamentos feitos a pé. É difícil escapar dos carroceiros que se deslocam de um a outro lado da cidade todos os dias. É importante assinalar que nem todos os carroceiros são moradores de rua, já que existem exemplos de catadores de lixo que têm moradia fixa, mesmo que continue na linha da precariedade em uma favela ou um cortiço. Existem também albergues para os moradores de rua que catam lixo. Às vezes o chefe de família se encarrega de sustentar o núcleo através da catação de lixo e pernoita na carroça, enquanto a família mora numa periferia de difícil acesso. 
A carroça é mais que uma ferramenta de trabalho; registram-se casos em que os moradores de rua utilizam-na como casa móvel. Às vezes dormem na carroça a fim de proteger o material catado, que será vendido no dia seguinte. Precisa-se aclarar que nem todos os carroceiros utilizam-na como moradia permanente, pois existem casos de indivíduos que moram provisionalmente na cooperativa, em cortiços ou em outros lugares distantes (RABINOVICH/TACHNER, 1998, p. 18).

A prefeitura permite-lhes três meses de estacionamento, pelo que é usual observar as carroças que são utilizadas como moradia estacionadas esse período de tempo nas ruas das áreas centrais, perto de onde se concentra grande quantidade de lixo da cidade que pode ser catado. Ao terminar esse prazo se deslocam; na maioria dos casos ficam na mesma área, pois relacionam sua localização com alguma estratégia de subsistência. Nesses moradores de rua, existe um arraigado senso de território apropriado. O caso do neonômade, ou morador de rua que realiza deslocamentos curtos em carroças, se distingue porque a carroça, além de um elemento de trabalho, constitui sua moradia. A decoração das carroças dos neonômades também as distingue, pois nelas se tem um investimento de tempo e esforço por parte de seus usuários. As cores e elementos as constituem como uma expressão da individualidade de seus proprietários e até de uma declaração de suas preferências pessoais e opiniões políticas. Acontece o mesmo com os refúgios precários dos moradores de rua, pois observa-se um design espontâneo e escolhas conscientes que produzem uma estética própria. Esses deslocamentos são diferentes dos deslocamentos na cidade conhecidos como longos e amplos. A pesquisa nacional dos moradores de rua (PNMR) realizada em 2009 revelou muito dos deslocamentos longos. Entre os fatos 
revelados, está o de que, "ao se deslocar, pelos mais diversos motivos, não conseguiu no novo município uma inserção profissional, ou somente conseguiu uma inserção precária e passou a dormir nas ruas". Observa-se que os moradores de rua em uma cidade registraram prévios deslocamentos dentro do mesmo Estado, sendo que a maioria dessas pessoas é "originária do mesmo município em que se encontra ou se deslocou de municípios situados no mesmo estado" (QUIROGA / RODRIGUEZ -org-, 2009, p. 91, 101).

Deve-se ter claro que muitos moradores de rua, $45,8 \%$ segundo a PNMR, permaneceram na mesma cidade de origem. Os deslocamentos longos feitos por alguns, $30,3 \%$ segundo a PNMR, no mesmo Estado, o que indica a procura do centro urbano que possa garantir recursos para a sobrevivência na rua. Existe uma migração interna nos estados brasileiros, do campo à cidade, mas em nível nacional isso é indicativo da permanência no estado de origem. Alguns indivíduos fazem dos deslocamentos uma forma de vida; essa dinâmica data de tempos antigos, mas foi identificada nas pesquisas da população de rua na década de 90. São conhecidos como "trecheiros" aqueles moradores de rua que se deslocam de cidade em cidade, orientados pelas temporadas altas de trabalho. O período de permanência em cada cidade varia, e eles percorrem grandes distâncias em diferentes estados. Esse grupo não representa uma maioria dentro da população de rua, mas a "sua presença não é desprezível, chegando a 11,9\% aqueles que já viveram em 6 ou mais cidades". Mesmo que a maioria deles, 45,3\%, tenha apresentado oportunidades de trabalho como seu principal motivo, existem também os casos, $18,4 \%$, em que os conflitos intrafamiliares são o motivo dos deslocamentos longos. Às vezes os deslocamentos 
longos são cíclicos, pois alguns tendem a voltar às cidades que conhecem, procurando oportunidades.

Os períodos são diferentes, assim como os mercados laborais procurados. A renda obtida determina se é possível dormir na pensão ou se é necessário dormir na rua, o que assinala uma grande capacidade de adaptação às circunstâncias. Os trecheiros, por serem trabalhadores nômades, às vezes realizam deslocamentos em todo o país, por isso podem desenvolver atividades variadas: construção civil, trabalho agrícola, garimpo, pesca, etc. (QUIROGA / RODRIGUEZ -org-, 2009, p. 88, 91). 

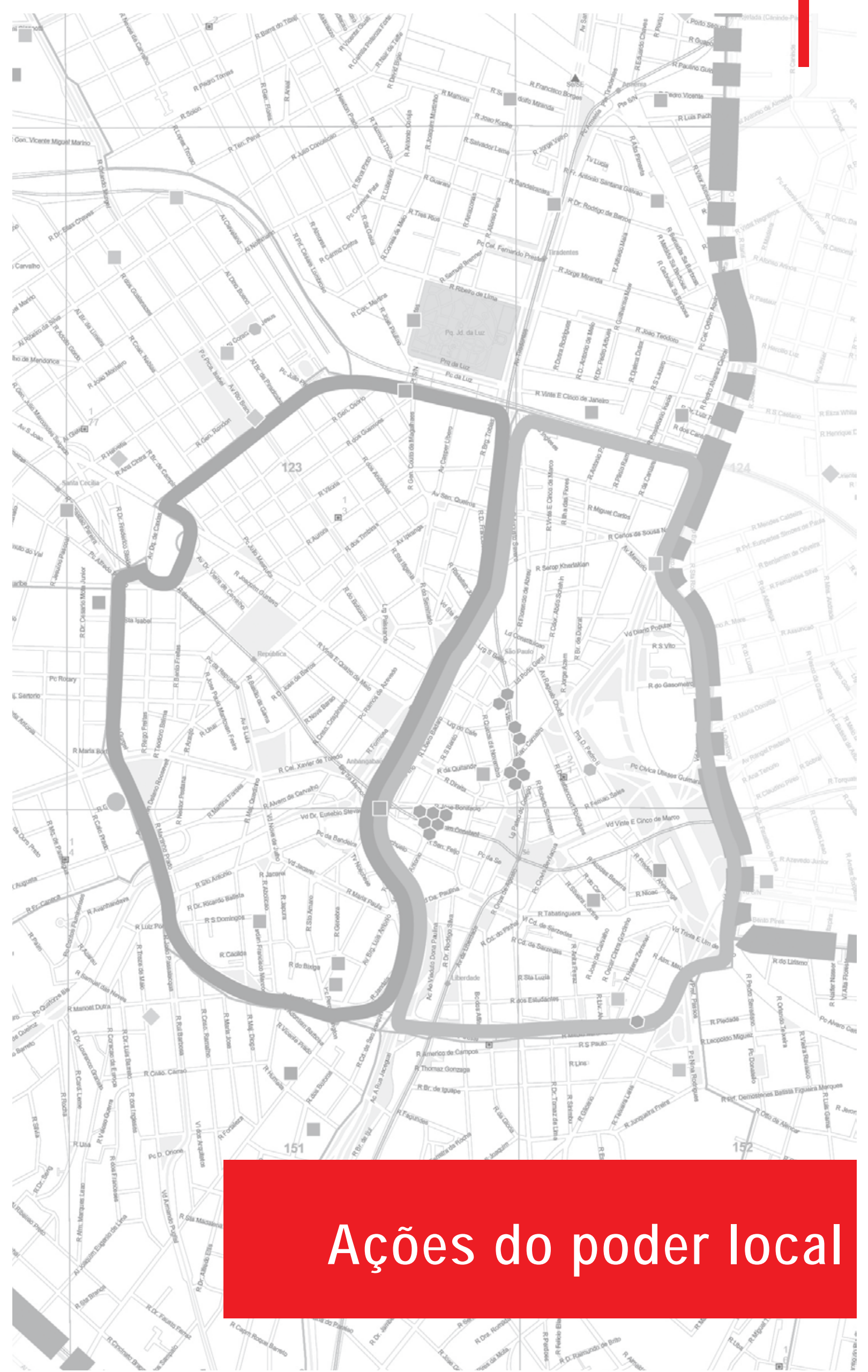


\subsection{AS AÇÕES PÚBLICAS LOCAIS}

A cidade de São Paulo passou por processos importantes na segunda metade do século XX. Nesse período, tanto a crise mundial das décadas de 70 e 80 no território brasileiro quanto as mudanças implementadas por cada gestão dos governos locais tiveram consequências na cidade. Foram três os fatores das políticas públicas locais que determinaram o panorama atual da Área Central: 1) a inconsistência das políticas públicas relativas à área central; 2) a definição do território e 3) a descentralização administrativa do território.

\subsubsection{INCONSISTÊNCIA DAS POLÍTICAS PÚBLICAS RELATIVAS À ÁREA CENTRAL}

Num período de 32 anos, a cidade de São Paulo teve 14 gestões municipais, com 4 prefeitos interinos. São dois os prefeitos que foram reeleitos nesse período: Paulo Salim Maluf (1969-1970/1993-1996) e Gilberto Kassab (2006-2009/2009-2012). Esse período também se caracteriza por ter duas modalidades para se nomear o governo local. De 1969 a 1986, os gestores municipais foram nomeados diretamente pelo governo local, uma das medidas da ditadura militar a fim de prevenir convulsões político-sociais. Nessa época, foram nomeados 7 prefeitos e 2 interinos. A época democrática trouxe a modalidade de nomeação por votação, que se iníciou em 1986 e ocorre até hoje (2012).Em ambos os períodos, cada uma das gestões apresenta inconsistências. Os programas de cada partido político, os projetos urbanos imediatistas e a incapacidade de continuar políticas de gestões anteriores parecem 
ter regido as ações de cada gestão municipal. Para entender o panorama de 2000 até 2010 na Área Central, precisa-se retroceder décadas. Na década de 70, iniciase um período decisivo na história da área. Com a expansão do território, emergem as necessidades de melhorar os transportes públicos e o sistema viário da cidade. Inicia-se, então, o Plano Metropolitano de Desenvolvimento Urbano I (PMDU I/1970), com vistas ao ordenamento territorial da área metropolitana. Um ano após o PMDU I, foram aprovados o Plano Diretor de Desenvolvimento Integrado (PDDI/1971) - em escala municipal, a fim de atingir as necessidades em uma escala menor - e a Lei de Zoneamento (1971). Uma das intervenções mais importantes da década não estava, porém, vinculada ao PDDI: a malha de linhas de metrô - ela "fora planejada de forma independente". O metrô apoiava a política de expansão horizontal da cidade. O centro era o protagonista desse sistema de transporte; havia também a perspectiva da expansão dos trabalhos com a adição posterior de mais linhas nas décadas seguintes. Os trabalhos da primeira linha do metrô, Norte-Sul, foram complementados por "obras de reurbanização dos espaços urbanos históricos, como o largo São Bento e a nova Praça Sé" (ZANETTI, 2005, p. 94, 95).

Em 1974, quando foram concluídos os trabalhos da primeira linha do metrô, a nova modalidade de transporte trouxe uma nova forma de chegar e sair do centro e teve um forte impacto na cidade. Os motoristas tiveram que mudar seus trajetos devido às mudanças no setor. A inauguração dos calçadões para pedestres nos bairros Sé e República (1976) gerou impactos em menor escala: os pedestres ganharam em acessibilidade e estacionamentos foram criados para os que tivessem que visitar a lojas da região. 


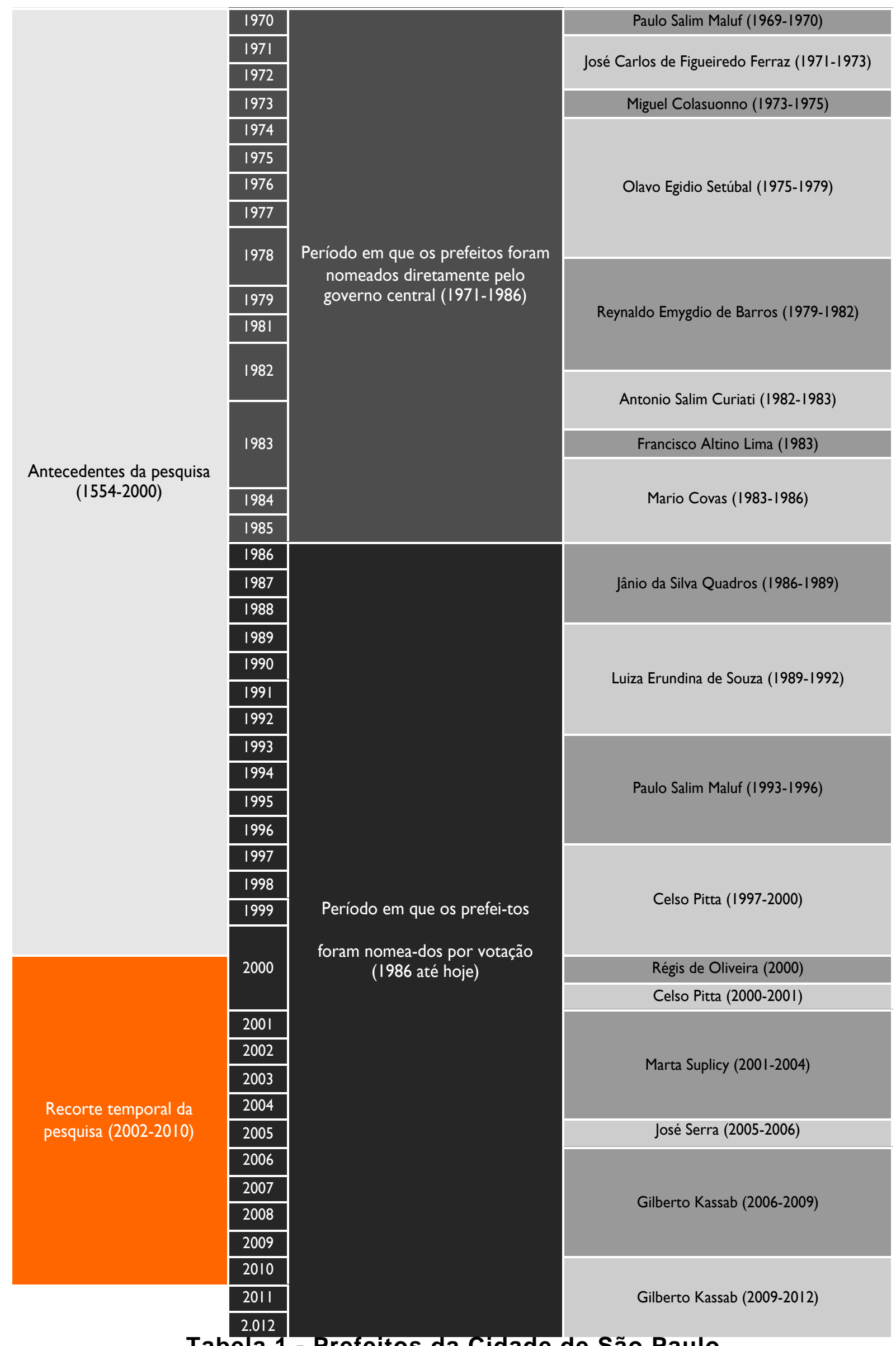

Tabela 1 - Prefeitos da Cidade de São Paulo 
Dez anos de ações focadas na expansão da cidade, de 1964 a 1974, apresentam como uma de suas consequências o esvaziamento do centro pelo êxodo de suas funções a novas centralidades e de seus residentes para outras áreas. Esse esvaziamento foi seguido por um intenso processo de degradação da área central. A paralisação das ações públicas no setor coincide com o começo da crise mundial, que limitou o poder de ação do setor público pela falta de recursos financeiros para resolver os problemas que emergiam no local. O ano de 1974 também marca o início de um período de desaceleração de intervenções urbanas do setor público; isso determina os projetos futuros já que houve poucos recursos para as grandes reformas que a cidade precisava. O resultado tanto da crise de petróleo interna (1973/1974) quanto da crise econômica mundial foi o "esfriamento das intervenções do setor público, sem que se tivesse, contudo, concluído o processo de reestruturação urbana". Mesmo assim, o setor público consegue terminar alguns dos projetos de infraestrutura, mas deixando-se de lado outras necessidades sociais desatendidas, tal é o caso da habitação (ZANETTI, 2005, p. 93).

Esse processo de degradação foi reforçado com a chegada do metrô, pois sua malha não condizia com a malha original da cidade, e os espaços novos não condiziam com as construções antigas, que passaram a sofrer, em primeiro lugar, uma degradação funcional: foram abandonadas pelas autoridades, ficando vagas, e passaram a ser invadidas por outro tipo público, desfavorecido economicamente, o que contribuiu, por fim, para sua degradação física. O final da década de 70 traz uma mudança crucial no olhar para a região: nesse período, evidencia-se que "o processo de readequação do centro se apresentava com um volume significativo de projetos e obras de caráter 
revitalizante e pontual, sem fazer parte de um plano ou programa". Nesse período os bairros da cidade se transformaram; nos centrais se geraram espaços residuais devido aos trabalhos do metrô; com isso vieram a degradação ambiental e os altos índices de ruídos. As condições dos bairros da periferia são até hoje precárias em parte devido a sua rápida constituição (ZANETTI, 2005, p. 93, 94).

Quando se percebem essas consequências, cria-se um "Plano Integrado da Área Central" (PIAC/1976) com o objetivo de coordenar todas as intervenções nessa área. O PIAC foi elaborado pela Coordenadoria Geral de Planejamento da Prefeitura da cidade. Nele a prefeitura analisou as transformações decorrentes do impacto da entrada em operação do novo sistema de transporte em massa, o metrô, na área central. Ao reconhecer os impactos da recém-inaugurada linha do metrô, a cidade estava abordando os problemas de maneira direta. Esse plano seria uma tentativa de solucionar os problemas do centro, mas ele não se concretizou: "o fato é que nem um plano específico para a área central, nem a revisão do plano diretor da Cidade lograram êxito". As problemáticas nesse local continuaram contribuindo para seu processo de degradação. O centro da cidade teve, nesse período, um grande volume de intervenções na infraestrutura de transporte, mas esse quesito, que era a prioridade do setor público, carecia de um plano específico. Foi notória a ausência de um plano urbanístico geral, no qual se integrassem todas as linhas de trabalho da prefeitura (transporte, habitação, meio ambiente, etc), isso teria orientado a continuidade das ações públicas nas décadas seguintes. O resultado foi uma série de intervenções pontuais e desarticuladas, sem nenhuma continuidade no tempo (ZANETTI, 2005, p. 95). 
No momento em que as consequências das ações públicas no centro se evidenciam, a Avenida Paulista surge como o "Novo Centro". Inicia-se o processo de desconcentração, no qual algumas funções do Centro tradicional trasladam-se aos novos centros, primeiro à Avenida Paulista e posteriormente a Pinheiros; o resultado disso seria que o Centro se tornaria um lugar de passagem. Nesse momento, o Centro reunia grandes multidões próximas aos terminais de transporte coletivo, sendo esse o principal motivo pelo qual as pessoas passavam pelo lugar. No nível administrativo, apresenta-se uma atuação desarticulada entre as escalas administrativas municipal, estadual e federal. Essas duas linhas de trabalho geram projetos descontínuos e fragmentados, refletem "o desmanche gradativo do Sistema de Planejamento e Administração Metropolitano (SPAM)" (ZANETTI, 2005, p. 101).

Ao longo da década de 80, apresentam-se três Planos Diretores para a cidade de São Paulo. O primeiro, Plano Diretor 1985-2000, ficou como uma tentativa. Em 1986 é aprovada a Lei de Zoneamento, focando a moradia precária, que foi declarada inconstitucional. O Plano Diretor 1988 tornou-se lei, com a ideia de criar um instrumento flexível às necessidades públicas e privadas. Posteriormente viria outra tentativa não concretizada, a do Plano Diretor de 1989. Nessa década, também se destaca o processo de democratização que marcou a apresentação de uma nova dinâmica no governo local, pois os prefeitos ate então eram eleitos alternadamente em períodos irregulares, o que para muitos transformou o cargo de prefeito em um instrumento de atuação político-partidária. Essa nova dinâmica fez com que as ações fossem a curto prazo e descontínuas, portanto os programas e os planos seguiram essa tendência. Nesse contexto foi difícil instituir um sistema de planejamento coerente e coeso para 
orientar o crescimento da cidade de São Paulo. Houve um Plano Diretor em 1991, que foi deixado de lado pelas gestões seguintes (Maluf/Pitta). O Plano apresentava 20 Administrações Regionais, uma nova tentativa de renovação urbana, zonas adensáveis, fundo de urbanização e as Zonas Especiais de Interesse Social (ZEIS). Na década de 90, as ações da prefeitura continuam desvinculadas dos instrumentos de ordenamento territorial; exemplo disso é a aprovação de ações como a Operação Urbana Anhangabaú (OUA/1991), a Operação Água Espraiada (1995), a Operação Urbana Faria Lima (OUFL/1996) e a Operação Urbana Centro (OUC/1997). Por um lado, com a OUA se promoveu o investimento na reurbanização do Vale de Anhangabaú, o que concretizou os trabalhos realizados na área entre 1981 e 1992. Por outro lado, com a OUFL se apoiou o desenvolvimento de Pinheiros, o "Novíssimo Centro", por meio das operações urbanas “Água Espraiada"(1995) e "Faria Lima”(1996). A descontinuidade de ações se evidencia quando se promove o deslocamento de mais funções para esse novo centro, adicionando-se o traslado dos investimentos públicos e privados a essa locação em um momento crítico, pois era o centro degradado que ainda precisava muito de investimentos. Mesmo que as ações tenham impulsionado diferentes áreas das cidades, "a tentativa de aperfeiçoar as Operações Urbanas será uma opção que marcará sua continuidade [das Operações Urbanas] nas ações das três gestões a partir dos anos de 1990" (HOWARD, 2008, p. 177-178).

Com a OUC, as autoridades locais focaram seu agir no setor hoteleiro e em incentivos para as normas de construção e ocupação na Área Central. As intervenções não atenderam, portanto, às necessidades do complexo setor, que continuou com ações sem um plano integrado, focando-se nas obras viárias. As quatro gestões, Barros/ 
Quadros/Maluf/Pitta, em um período de 14 anos, caracterizaram-se pela implantação de práticas urbanísticas desarticuladas e projetadas a curto prazo, adicionando-se a eles os empreendedores imobiliários da época. Parece que um plano que unificasse as ações e que as projetasse a longo prazo não era prioridade. As ações locais das gestões locais (Quadros/Maluf) focaram-se em grandes obras viárias que de maneira indireta beneficiaram os empreendimentos imobiliários dos privados. Compensavase a priorização do investimento privado com projetos direcionados às camadas mais pobres da cidade, paliativos, que não atingiram as problemáticas da cidade. Apesar de as ações da Prefeitura terem favorecido o desenvolvimento de outras áreas da cidade, em 1991 surgiria no setor privado um novo ator da requalificação da Área Central: a Associação Viva o Centro (AVC). O foco desse novo ator era claro: "o Centro como um todo, independente das delimitações propostas, não foi apropriado pelo poder público, que deliberou ao terceiro setor esta tarefa". O fortalecimento da Viva o Centro "durante o período de 1993 até 2004 demonstra que a compreensão da cidade não é função exclusiva do poder público e que a gestão pode ser compartilhada" (HOWARD, 2008, p. 216).

A realização de estudos, projetos e, mais importante ainda, a promoção de parcerias entre o setor púbico e o privado seria um dos resultados mais evidentes da AVC. Outro dos resultados da pressão desse novo ator seria a criação do Programa de Requalificação Urbana e Funcional do Centro de São Paulo (PROCENTRO) em 1993. A AVC não é um ator passivo ou silente, mas um órgão que desenvolve, coordena e propõe; ao articular distintos atores, esperavam que suas ações focadas no centro tivessem uma abrangência metropolitana. 
Esse novo espaço no poder local se apresentaria na década junto com os resultados dos concursos impulsionados pela AVC: Concurso Nacional de Ideias de Preservação do Bairro do Bexiga (1991) e o Concurso Nacional de Ideias para um Novo Centro para São Paulo (1996). Apresentaram-se avanços após a criação do PROCENTRO: a "reabertura de algumas ruas para o tráfego de veículos; ampliação em três linhas de trólebus circulares, terminais de ônibus e reforma dos viadutos do Chá e Santa Ifigênia" (HOWARD, 2008, p. 174).

No começo do novo século, a perspectiva de um novo financiamento fez com que o poder local retomasse o assunto da requalificação do centro da cidade de maneira mais integral. Na gestão Suplicy, redirecionou-se o olhar ao Centro da cidade, adaptaram-se as propostas das intervenções a fim de conseguir os recursos para realizá-las. O alvo era conseguir compartilhar os gastos com o Banco Interamericano de Desenvolvimento (BID). Em 2001, apresenta-se o Estatuto da Cidade, com altas expectativas e relação a ele, esperando-se que supriria "o espaço deixado vago pelo processo de institucionalização do sistema de planejamento". Torna-se imperativo para a cidade criar um plano diretor (ZANETTI, 2005, p. 125).

Havendo a possibilidade de financiamento externo destinado à área central, a ser complementado pelo poder local, e a exigência de se criar um novo plano diretor regido pelas demandas específicas do Estatuto da cidade, apresentam-se duas ações nesse momento:

- Definir o território

- Descentralizar a administração da cidade 


\subsubsection{DEFINIÇÃO DO TERRITÓRIO}

Desde a fundação da cidade de São Paulo, em 1554, a área que conhecemos como o Bairro Sé era, no imaginário coletivo, todo o território que constituía "a cidade", por isso ainda hoje o chamam de "Centro Velho". À medida que a cidade crescia, a noção da área que constitui o centro foi mudando, mas o Bairro Sé continuou sendo seu ponto de partida. Adicionou-se o termo "Centro Novo", formado pelos bairros Sé e República, para nomear a área comercial da cidade no final do século XIX e começo do XX. Os dois bairros foram considerados o "centro da cidade" até meados do século XX. O termo para nomear a Área Central da cidade foi mudando; começou com "Centro Velho" e passou por "Centro Principal”, "Centro Metropolitano”, "Centro Expandido", "Centro Extendido" até chegar a "Centro Histórico". Cada um desses termos responde tanto aos planos locais e regionais quando às tendências urbanísticas de cada década. Além da busca por um termo, as autoridades locais trabalharam em definir a área que constituía o centro. Nos anos 80, o território que compunha a Aglomeração Central da cidade incluía um total de 23 bairros. Considerava-se área de abrangência do Centro Principal um raio de dois a três quilômetros em torno da Praça da Sé, numa aproximação bastante imprecisa do território. É importante assinalar que cada gestão municipal delimita o Centro de modos diferentes, algumas incluem territórios que outras excluem; essas abordagens distintas do mesmo território têm consequências tanto no Centro tradicional como no "Novíssimo Centro", no meio do rio Pinheiros. Na década de 90, a possibilidade de novas fontes de financiamento para investimentos no centro tornaram imperativa uma delimitação territorial mais precisa. Continuaram as tentativas de delimitar a área central; até esse ponto, o Centro de São Paulo 
tinha sido constituído por muitas configurações que iam desde os dois bairros tradicionais (Sé e República) até outros que apresentavam certo interesse nos projetos da Prefeitura (Barra Funda). A área denominada como centro foi constituída por 13 bairros, além de outros que somaram parte de alguns distritos de interesse. Concluiu-se que as delimitações respondem à necessidade de delimitar uma área nos momentos em que ia realizar-se alguma ação da Prefeitura.

Nos primeiros anos do século XXI, a administração local decide expandir os limites do centro com a intenção de conseguir investimentos numa área maior por parte do Banco Interamericano de Desenvolvimento (BID). O interesse no Centro da cidade fez com que os novos objetivos fossem tanto reabilitar os espaços públicos quanto abordar a problemática de habitação. Foram revisados os limites do centro a fim de incluir os bairros residenciais e assim beneficiá-los com os novos programas. Ao incluir outros distritos na delimitação do Centro, a prefeitura abre a porta também aos investidores locais, pois sabe-se que os limites são de interesse do mercado imobiliário; esse movimento é feito a fim de não só captar o interesse de um ator externo mas também para contar com atores internos ativos. A Prefeitura gera leis e decretos a fim de incentivar o investimento do setor privado. A nova delimitação do Centro da cidade tem total relação com o conceito proposto para essa área, esse conceito orienta as intervenções e gera apropriação urbana.

Considera-se um avanço das autoridades locais o consenso, havido em 2001, entre investidores, grupo sociais e autoridades na delimitação do Centro: nesse momento, seis distritos foram adicionados à delimitação do Centro, além dos bairros Sé e República: Bela Vista, Bom Retiro, Cambuci, Consolação, Liberdade e Santa Cecília. Esses oito 
distritos constituem a Subprefeitura Sé, formando o que conhecemos hoje como Área Central da cidade de São Paulo. A delimitação é de grande importância para a gestão territorial dessa importante área da cidade. Ao se definir o território que constituía a área central, as autoridades locais estavam desenvolvendo as primeiras ações para requalificá-lo.

Os programas da prefeitura, por sua vez, apresentam diferentes delimitações da Área Central, como se pode observar na comparação entre a Operação Urbana Centro (1997), o Procentro (2001) e o Programa Morar no Centro (2004). Isso nos indica que internamente a prefeitura não tem uma visão claramente consolidada sobre a delimitação do centro. Quem tem a cidade como objeto de estudo também apresenta interesse em definir a Área Central. Algumas das delimitações vindas de estudos sobre a área central concordam com áreas já propostas; outras adicionam novas centralidades às já existentes. Após 458 anos, ainda não se chegou a um consenso sobre a delimitação do centro da cidade. Os bairros Sé e República representam ainda hoje a medula do Centro, mas essa delimitação da área é uma cabeça de tamanho desproporcional em relação ao corpo que a metrópole de São Paulo constitui. Existe a necessidade de definir-se a área: "a indefinição de onde começa e onde se completa o Centro ou a Área Central de São Paulo é um ponto consensual para a sociedade e também para os autores" (HOWARD, 2008, p. 187). É impressionante que o Centro fosse definido tantas vezes ao longo das gestões do poder local; desde o início do processo de degradação, bairros foram incluídos e excluídos, porém terminaram constituindo-se diversas delimitações do Centro e os seus atores fizeram poucos consensos para sua abordagem. Algumas das configurações propostas para a Área Central foram atípicas, 
já que adicionaram as novas centralidades (como Pinheiros), o que integra bairros com dinâmicas diferentes das do centro tradicional. O que todas as delimitações tinham em comum é o objetivo por trás delas: concretizar ações na área central que tivessem como resultado a requalificação do solo e o fim do processo de degradação

Concluiu-se que existem quatro grupos que tentam delimitar o centro da cidade:

1 A população em geral - ao longo dos anos se gera uma delimitação do Centro no imaginário coletivo.

2 As autoridades locais - a fim de administrar o território, fragmentam-no e reconstroem-no em diferentes setores.

3 Os operadores ou técnicos que trabalham na prefeitura da cidade - a fim de implementar planos e programas para a requalificação da área central, propõem diversas delimitações do Centro.

4 Os estudiosos, interessados no setor. 


\begin{tabular}{|c|c|c|c|c|c|c|c|}
\hline Grupo & Ano & Termo & \multicolumn{2}{|c|}{$\begin{array}{l}\text { Centro Tradicional } \\
\qquad 1554-1881\end{array}$} & $\begin{array}{l}\text { Centro Expandido } \\
\qquad 1882-1914\end{array}$ & $\begin{array}{c}\text { Centro Expandido } \\
\text { e outras } \\
\text { centralidades } \\
\text { 1915-1929 }\end{array}$ & $\begin{array}{l}\text { Centro Estendido e outras } \\
\text { centralidades 1950-1962 }\end{array}$ \\
\hline I & Até 1900 & Centro Velho & Sé & & & & \\
\hline I & Até 1950 & Centro Novo & & República & & & \\
\hline I & $\begin{array}{l}1950- \\
1970\end{array}$ & Centro & Sé & República & & & \\
\hline 2 & 1965 & $\begin{array}{l}\text { Administração } \\
\text { Regional Sé /AR- } \\
\text { Sé }\end{array}$ & Sé & República & $\begin{array}{l}\text { Bela Vista, Bom Retiro, } \\
\text { Cambuci, Consolação, } \\
\text { Liberdade, Santa Cecília }\end{array}$ & Pari, Brás & $\begin{array}{c}\text { Barra Funda, Belém, } \\
\text { Mooca }\end{array}$ \\
\hline 2 & 1982 & $\begin{array}{l}\text { Aglomeração } \\
\text { Central }\end{array}$ & Sé & República & $\begin{array}{l}\text { Bela Vista, Bom Retiro, } \\
\text { Cambuci, Consolação, } \\
\text { Liberdade, Santa Cecília }\end{array}$ & Pari, Brás & $\begin{array}{c}\text { Barra Funda, Lapa, Vila } \\
\text { Madalena; Mooca; Santa } \\
\text { Efigênia, Perdizes, } \\
\text { Pinheiros, Vila Mariana, } \\
\text { Indianópolis, Jardim } \\
\text { Paulista, Belém }\end{array}$ \\
\hline 2 & 1982 & $\begin{array}{c}\text { Centro } \\
\text { Metropolitano }\end{array}$ & Sé & República & $\begin{array}{l}\text { Bela Vista, Bom Retiro, } \\
\text { Cambuci, Consolação, } \\
\text { Liberdade, Santa Cecília }\end{array}$ & & $\begin{array}{c}\text { Jardins, Paulista, Faria } \\
\text { Lima }\end{array}$ \\
\hline 2 & 1985 & Centro & Sé & República & $\begin{array}{l}\text { Bela Vista, Bom Retiro, } \\
\text { Cambuci, Consolação, } \\
\text { Liberdade, Santa Cecília }\end{array}$ & & $\begin{array}{c}\text { Barra Funda, Campos } \\
\text { Elíseos, Luz }\end{array}$ \\
\hline 2 & |99| & Área Central & Sé & República & $\begin{array}{c}\text { Bela Vista, Bom Retiro, } \\
\text { Consolação, Liberdade, Santa } \\
\text { Cecília }\end{array}$ & Pari, Brás & $\begin{array}{c}\text { Campos Elíseos, Santa } \\
\text { Efigênia, Luz }\end{array}$ \\
\hline 2 & |99| & $\begin{array}{l}\text { Administração } \\
\text { Regional Sé /AR- } \\
\text { Sé }\end{array}$ & Sé & República & $\begin{array}{l}\text { Bela Vista, Bom Retiro, } \\
\text { Cambuci, Consolação, } \\
\text { Liberdade, Santa Cecília }\end{array}$ & Pari, Brás & \\
\hline 2 & 1992 & Área Central & Sé & República & $\begin{array}{l}\text { Bela Vista, Bom Retiro, } \\
\text { Cambuci, Consolação, } \\
\text { Liberdade, Santa Cecília }\end{array}$ & Pari, Brás & $\begin{array}{l}\text { Barra Funda, Belém, } \\
\text { Mooca }\end{array}$ \\
\hline
\end{tabular}




\subsubsection{DESCENTRALIZAÇÃO ADMINISTRATIVA DO TERRITÓRIO}

Este processo foi gerado a partir da necessidade de se administrar o grande território metropolitano: rompeu-se com uma administração totalitária e uniforme e criaramse áreas menores a serem atendidas com regulamentos e ações locais específicas. O objetivo da descentralização era atender às necessidades particulares de cada um dos territórios menores. O primeiro registro da tentativa da descentralização administrativa da cidade de São Paulo data de 1957, pelo trabalho da Sociedade para Análise Gráfica de Mecanográfica Aplicadas aos Complexos Sociais SAGMACS, e pelos estudos do Plano Urbanístico Básico (PUB), mas ela foi concretizada depois disso. A descentralização do território foi iniciada em 1965; o município foi dividido em pequenas regiões administrativas, hoje conhecidas como Subprefeituras. Tinhase como objetivo o desenvolvimento de projetos relacionados com os serviços, a fiscalização e a implantação de equipamentos sociais; fracionar o território facilitava a execução dos projetos do poder local. Ao longo de 37 anos, apresentaram-se não só diversas alterações às Administrações Regionais (AR) como também tentativas para a implementação de uma administração descentralizada. Após o regime militar, na era democrática haveria uma tentativa concretizada dessa implementação no início da década de 90. A aprovação da Lei Orgânica do Município (LOM) apresenta critérios para dividir o território maior; a ideia era organizar e legitimar os territórios menores. A lei propunha administrar o território por meio de Subprefeituras, cujas atribuições, abrangência e competências foram especificadas. 
Essas ações implicaram a criação de novos empregos, pois os pequenos territórios correspondentes a cada Subprefeitura precisavam de representantes, para o que foram procurados servidores púbicos de carreira. As gestões seguintes não tiveram interesse no assunto até 12 anos depois, durante a elaboração do Plano Diretor Estratégico (PDE/2002). Na gestão de Marta Supily (2001-2004), retoma-se o tema sem fazer parte de reformas administrativas. A criação do PDE/2002 faz com que as Subprefeituras passassem a ser reconhecidas, e as ações do poder local implementadas de acordo com a divisão administrativa. A delimitação dos territórios foi baseada na divisão distrital da cidade de 1992 (Lei 11.920). Contava-se com 96 distritos, que constituíam 28 Administrações Regionais (AR). Na implementação da descentralização em 2002, adicionaram-se a essas 28 ARs mais 3 regiões, para formar um total de 31 Subprefeituras. A Região Centro é constituída pela Subprefeitura Sé. Em seguida à delimitação, desenvolveu-se o "Quadro situacional" de cada uma das Subprefeituras. No caso da Subprefeitura Sé, "o documento síntese sobre o diagnóstico da área central de 2002 indicou que a população não considerava a definição e os limites da região central do município" (HOWARD, 2008, p. 186).

O quadro situacional permitiu conhecer as fortalezas e fraquezas do território. panorama da Região Central estava claro: "a subprefeitura do Centro, portanto, teria alguns desafios iniciais no sentido de induzir o desenvolvimento e promover o seu 'repovoamento'" Ao haver um grupo de profissionais dedicados aos problemas da área, gera-se o Plano Regional Estratégico de 2004 (PRE/2004) da Subprefeitura Sé. Ele é constituído por: 1) Plano Urbanístico Ambiental; 2) Disciplina de Uso e Ocupação do Solo e 3) Desenvolvimento Urbano. O Plano Regional Estratégico promove 
a criação de planos específicos para os bairros da região a fim de atingir as necessidades mais pontuais dos territórios (HOWARD, 2008, p. 183).

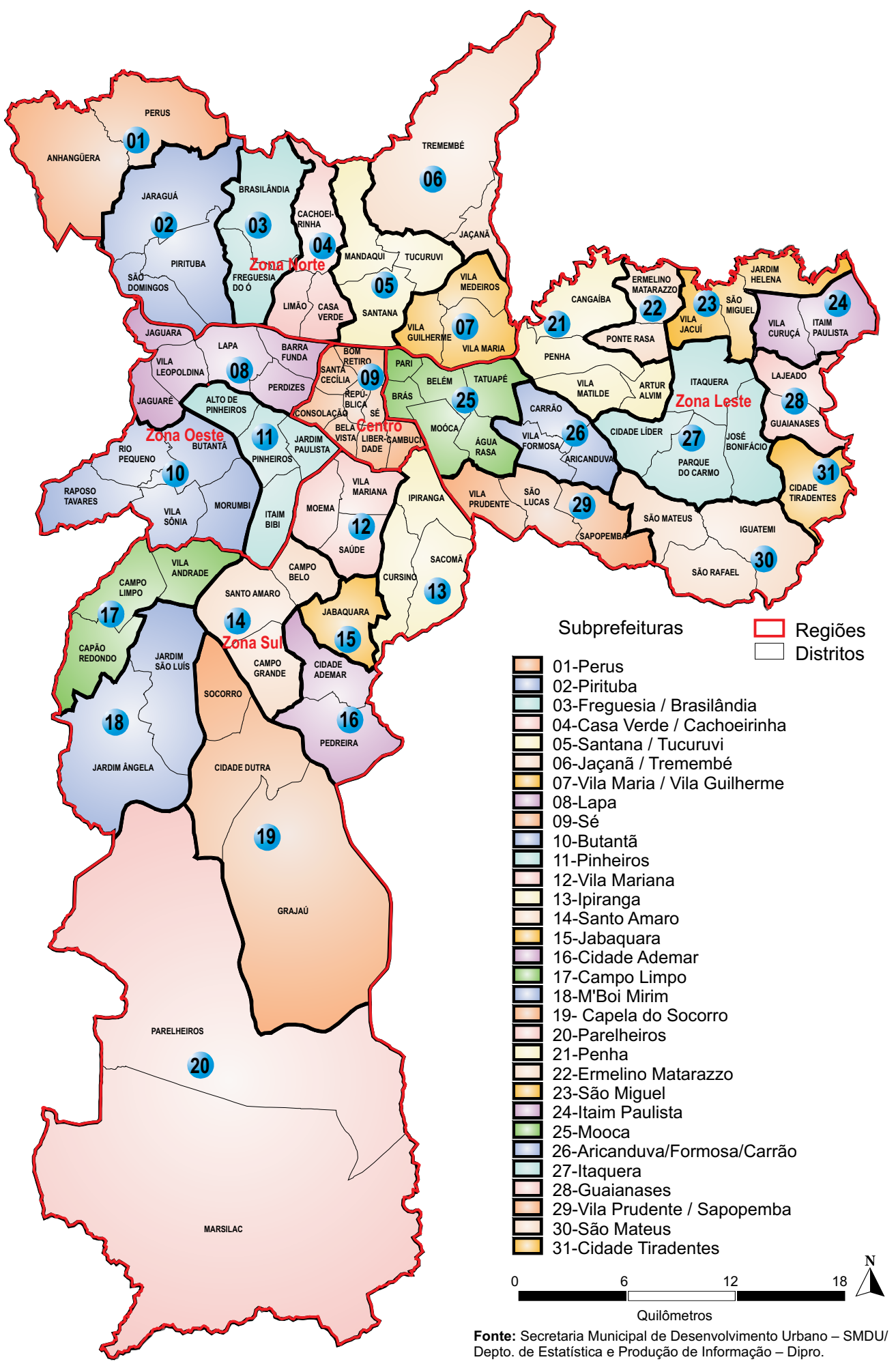

Mapa 21 - Subprefeituras da Cidade de São Paulo.

Prefeitura de São Paulo, 2002. 


\subsubsection{AS AÇÕES DE REQUALIFICAÇÃO DA ÁREA CENTRAL}

\begin{tabular}{|c|c|c|c|}
\hline Ano & Órgão & Ação / Intervenção & Componentes \\
\hline \multirow{5}{*}{1974} & \multirow{5}{*}{$\begin{array}{l}\text { Cogep e } \\
\text { Emurb }\end{array}$} & \multirow{5}{*}{$\begin{array}{l}\text { Linha Norte-Sul do } \\
\text { Metrô }\end{array}$} & $\begin{array}{l}\text { Estação Sé / Praça } \\
\text { Sé e Largo São } \\
\text { Bento }\end{array}$ \\
\hline & & & Largo Liberdade \\
\hline & & & Largo São Francisco \\
\hline & & & Pátio do Colégio \\
\hline & & & Parque Dom Pedro II \\
\hline 1974 & Emurb & $\begin{array}{l}\text { Renovação Urbana - } \\
\text { Área da Luz }\end{array}$ & \\
\hline 1976 & Emurb & Calçadões & $\begin{array}{l}\text { Nas Praças da Sé e } \\
\text { República, as ruas } \\
\text { tiveram tratamentos } \\
\text { de pisos, } \\
\text { arborização, bancos } \\
\text { e iluminação. }\end{array}$ \\
\hline 1976 & Emurb & $\begin{array}{l}\text { Reabilitação do } \\
\text { edificio Martinelli }\end{array}$ & $\begin{array}{l}\text { O prédio recebe } \\
\text { repartições públicas } \\
\text { municipais }\end{array}$ \\
\hline 1978 & Emurb & $\begin{array}{lr}\text { Restauração } & \text { do } \\
\text { Viaduto } & \text { Santa } \\
\text { Efigênia } & \end{array}$ & $\begin{array}{l}\text { Transformado em } \\
\text { passagem exclusiva } \\
\text { de pedestres }\end{array}$ \\
\hline 1981 & Emurb & $\begin{array}{l}\text { Reconversão da } \\
\text { Casas das Retortas }\end{array}$ & \\
\hline
\end{tabular}




\begin{tabular}{|c|c|c|c|}
\hline 1992 & Emurb & Bulevar São João & \\
\hline 1992 & Emurb & $\begin{array}{l}\text { Reabilitação do } \\
\text { Parque D. Pedro II }\end{array}$ & \\
\hline 1993 & $\begin{array}{l}\text { Governo do } \\
\text { Estado }\end{array}$ & $\begin{array}{ll}\text { Reforma } & \text { da } \\
\text { Pinacoteca } & \text { do } \\
\text { Estado } & \end{array}$ & \\
\hline 1997 & Procentro & $\begin{array}{l}\text { Operação Urbana } \\
\text { Centro }\end{array}$ & \\
\hline 1999 & Procentro & $\begin{array}{lr}\text { Reabilitação } & \text { do } \\
\text { Viaduto } & \text { Santa } \\
\text { Ifigênia } & \end{array}$ & Segundo trabalho \\
\hline 1999 & & $\begin{array}{l}\text { Edifício Maharishi } \\
\text { São Paulo Tower }\end{array}$ & \\
\hline 1999 & & $\begin{array}{l}\text { Inauguração da Sala } \\
\text { São Paulo }\end{array}$ & \\
\hline 2000 & Procentro & $\begin{array}{l}\text { Reabilitação do } \\
\text { Viaduto do Chá }\end{array}$ & \\
\hline \multirow{4}{*}{2001} & \multirow{4}{*}{ Procentro } & \multirow{4}{*}{$\begin{array}{l}\text { Plano } \\
\text { reconstrução } \\
\text { centro }\end{array}$} & $\begin{array}{l}\text { Programa Andar no } \\
\text { Centro }\end{array}$ \\
\hline & & & $\begin{array}{l}\text { Programa Morar no } \\
\text { Centro }\end{array}$ \\
\hline & & & $\begin{array}{l}\text { Programa Trabalhar } \\
\text { no Centro }\end{array}$ \\
\hline & & & $\begin{array}{l}\text { Programa Descobrir } \\
\text { o Centro }\end{array}$ \\
\hline
\end{tabular}




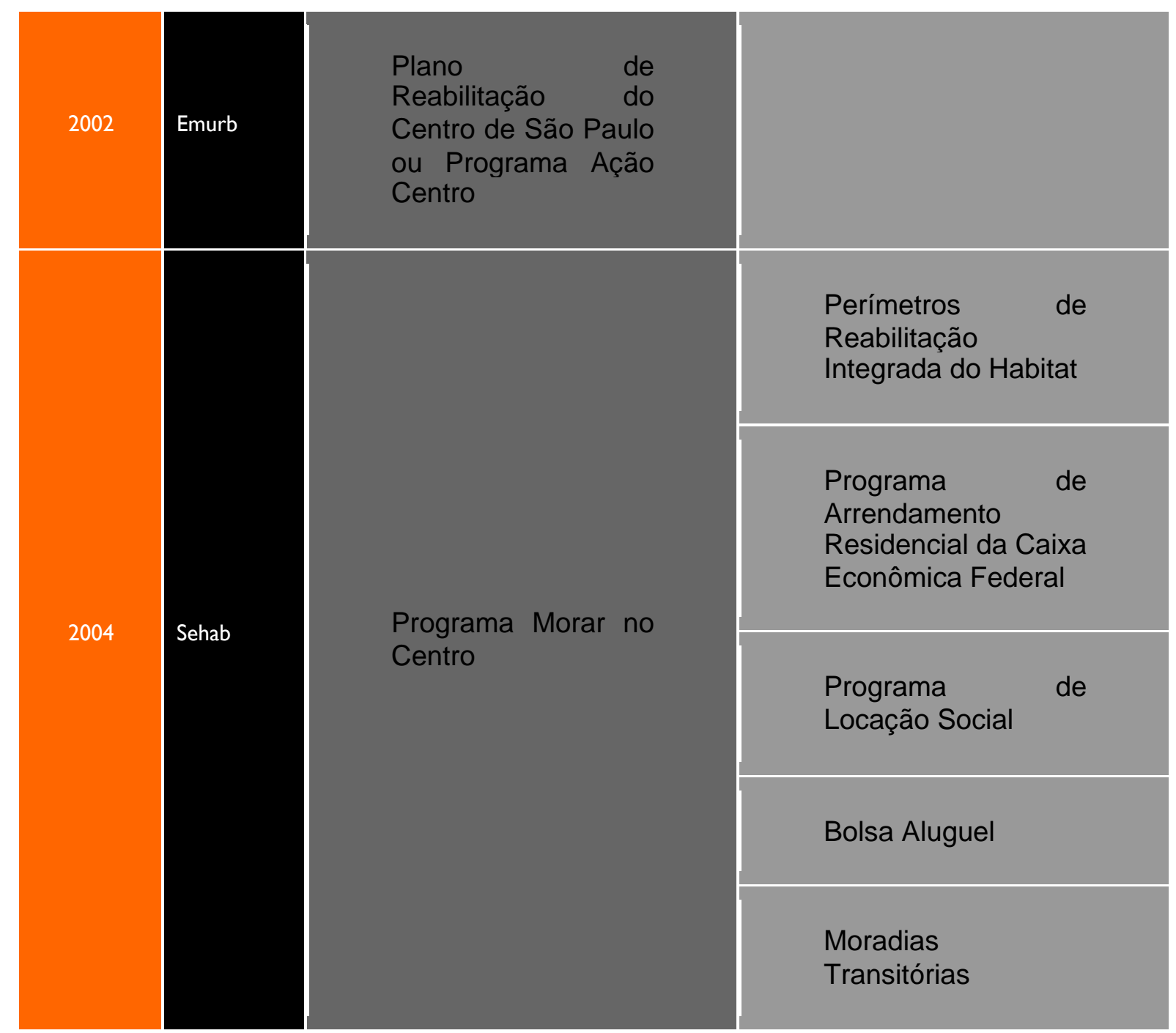

Tabela 3 - Ações da Prefeitura no Centro da Cidade de São Paulo 


\subsection{AS AÇÕES DE ASSISTÊNCIA SOCIAL}

Entende-se por "necessitado" aquele indivíduo que, por não conseguir suprir a si mesmo recursos para atender a suas necessidades básicas, precisa da assistência do Estado; ele a procura nos órgãos de assistência social das diferentes escalas (Municipal, Estadual e Federal). Conceitualmente a assistência social brasileira até hoje concentra-se no estado de necessidade e não na situação do necessitado, por isso a assistência se classifica pelo tipo de "necessidade" e o seu público-alvo é estratificado por idades (INSTITUTO PÓLIS / PUC, 2002, p. 24).

Alguns estudiosos apresentam a ideia de que essa abordagem impulsiona a demonstração da "precariedade" do indivíduo, já que, para acessar a assistência social oferecida pelas autoridades, em qualquer uma de suas escalas, ele precisa apresentar suas carências ante os atendentes do órgão de assistência social. Deve-se considerar que a incapacidade do indivíduo de cobrir suas necessidades repercute no exercício de sua cidadania e ao não conseguir o completo exercício dela são excluídos da sociedade civil, o que deixa uma parte da população fora do setor formal. O objetivo da Assistência Social é induzir o necessitado ao processo de universalização da cidadania, mas as crises econômicas truncaram esse processo, pois a falta de recursos repercute nas políticas de assistência social em todas as escalas governamentais. Uma das consequências disso é o crescimento e a perpetuação da desigualdade social no contexto brasileiro. No Brasil, é longa a história das organizações sociais que prestam auxílio àqueles que o necessitam. Começa no Período Imperial, passa pela Primeira República e segue até hoje; mas sendo o nosso tema de interesse as ações 
do poder local relacionadas com os moradores de rua na cidade de São Paulo, a análise começa no século XX, no período do Estado Autoritário, posterior a 1964. Por um lado, o Estado atinge o tema da assistência social nas diferentes escalas com diversas iniciativas como, por exemplo, a Fundação Estadual para o Bem-Estar do Menor (FEBEM) e, por outro, a sociedade civil continuou a sua tarefa filantrópica com grupos de amigos do bairro, associações de moradores, pastorais e outras sociedade sem fins lucrativos e com objetivos benéficos. No plano municipal, a Divisão de Serviço Social (DSS) da Prefeitura de São Paulo se transforma em 1966 na Secretaria Municipal de Bem-Estar Social (SEBES), hoje conhecida como a Secretaria de Municipal Assistência e Desenvolvimento Social (SMDAS). Essa abordagem teve consequências sobre a atenção aos segmentos sociais em situação de vulnerabilidade e risco, que até então era conduzida pelo governo do Estado. Consideram-se 1977 e 1979 anos importantes na história da assistência social, pois, como resultado dos movimentos sociais, constituiu-se um atendimento municipal, modelo de atendimento descentralizado aos necessitados. A discussão das políticas públicas de assistência social continuou ao longo dos períodos seguintes dos governos locais. Nesse ponto, embora se iniciem ações para atingir os segmentos da população que precisavam de assistência, elas carecem de um eixo estratégico que as oriente em sua totalidade (INSTITUTO PÓLIS / PUC, 2002, p. 44).

Um dos primeiros esforços para assistir especificamente os moradores de rua no Brasil surge em 1984, na cidade de Rio de Janeiro, quando o governo municipal decide transformar a Fazenda Modelo, criada em 1947, em um abrigo. Sabe-se que chegou a albergar 2.500 pessoas. A ideia era que se tornasse um centro de resocialização, 
já que se reconhecia na população em risco a capacidade de concretizar o processo de "saída" da rua. Oferecia-se aos albergados moradia e alimentação, e o trabalho era desenvolvido nas hortas comunitárias; além disso, havia capacitação profissional em oficinas de aprendizagem. Em conjunto, as ações tinham como alvo a reinserção dos participantes no mercado formal de trabalho e a recuperação da sua cidadania.

Mesmo que os objetivos fossem corretos, as políticas públicas fizeram com que essa instituição se transformasse em um depósito de pessoas, tornou-se parte das políticas de higienização. Esse espaço passou a reunir uma multidão de pessoas com circunstâncias precárias e histórias diversas: criminosos, pacientes psiquiátricos, portadores de deficiências, crianças de todas as idades, adolescentes, idosos moribundos e doentes crônicos acamados. O estado precário das instalações da Fazenda Modelo fez com que as autoridades começassem os trabalhos para transformar de novo esse espaço. O fato de que albergasse uma população que não era atendida por outras instituições públicas produziu a superlotação; a demanda sobrepujou a capacidade das instalações. Um dos fatos importantes que surgiu é que, a partir da criação desse centro, ficou evidente que as cidades não estavam preparadas para o atendimento social específico dos moradores de rua. A tendência geral era a expulsão dos moradores de rua de um lugar para outro, ao mesmo tempo em que não havia equipamentos focados no atendimento dessa população. Nessas primeiras tentativas de formalizar a assistência social específica para essa população, o albergue era a única opção de atendimento para eles. O advento da Constituição (1988) abriu a perspectiva para uma nova classe de assistência social, em que o atendimento à população em risco era tanto um direito dos cidadãos, 
quanto um dever do Estado. As vertentes dessa abordagem foram duas: a saúde e a previdência social. O resultado desse processo de democratização no Brasil foi a Lei Orgânica da Assistência Social (LOAS/1993); mesmo assim, no início se relegava à filantropia o trabalho da assistência social, pois no país sempre existiu uma estreita vinculação entre a assistência social e as organizações civis ou privadas. A LOAS estabelece um modelo de gestão descentralizada da Política de Assistência Social, que se desenvolveu nas três escalas: nacional, estadual e municipal; nesse modelo, o governo, a sociedade civil e os usuários têm representantes (KOGA, 2006, p. 49).

Outra das consequências dessa transição democrática foi uma filantropia vigiada, já que se estabeleceram os marcos legais para as Organizações Não Governamentais (ONGs). Emergem nesse período os movimentos de defesa de direitos, com isso se criam novos movimentos sociais, que fogem do simples assistencialismo e se concentram na reinvindicação dos direitos básicos, e obtiveram relevância com seu poder convocatório. O início da década de 1980 se caracterizou por um olhar corretivo em relação à assistência social focada nas crianças de rua: as medidas distavam do assistencialismo e versavam no repressivo-correcional, específico para esse grupo etário. A assistência específica para essa porção da população de rua foi dada pela Pastoral do Menor (1977) e pelo Movimento Nacional de Meninos e Meninas de rua (1985). Outros atores se adicionaram à luta pelas crianças de rua, mas eram do setor privado e não do público, exemplo disso foram os Centros de Defesa dos Direitos da Criança e do Adolescente (CEDECAs). A promulgação da Constituição em 1988 abriria novas perspectivas em relação ao atendimento e assistência social para a população em risco, já que promoveu a "proteção integral", especificamente para aqueles mais 
vulneráveis. Esse processo de transição de um olhar corretivo à assistência abrangente das crianças de rua culminaria com a criação do Estatuto da Criança e do Adolescente (ECA/1990), a dissolução da FEBEM e a consequente criação da Fundação Centro de Atendimento Socioeducativo ao Adolescente (Fundação CASA/2006).

No caso da prefeitura de São Paulo, os gastos com assistência social apresentaram fortes variações ao longo das décadas de 1980 e 1990, sem dúvida consequências das crises econômicas. Mesmo que a Prefeitura não tivesse um órgão específico para as ações relacionadas com o povo de rua no período de 1984 a 1993, eles apresentaram um interesse pela crescente população de rua que se transformou em ações, especificamente com o diagnóstico da problemática na área central por meio do censo, o que eventualmente pautou as ações do atendimento dessa população. $\mathrm{Na}$ cidade de São Paulo, os gastos focados especificamente na população de rua surgem depois do advento da LOAS em 1993; nesse ano constituem 2\% do total do orçamento da assistência social; a partir de então, gradativamente aumentaram, ano a ano, na cidade de São Paulo, até que em 1996 constituem 5,4\% do total do orçamento. Essa porcentagem apresenta nesse sentido continuidade e consequência. Na década de 1990, os resultados da democratização seriam ainda mais palpáveis, expandindo-se os conselhos setoriais, as ONGs e os movimentos sociais; pouco a pouco o interesse pelo fenômeno de rua foi crescendo, e as ações do poder local passaram a focar essa população em risco. Em relação aos gastos desse período, observa-se que, embora o atendimento específico para a população de rua se tenha iniciado em 1993, os esforços de contagem que orientaram esse tipo específico de assistência iniciaramse conceitualmente em 1990 e se concretizaram em 1991, ano do primeiro censo 
de moradores de rua em São Paulo. Nesses dois anos, o orçamento da Assistência Social da cidade apresenta uma quantidade significativa, sem dúvida investida em pesquisas e planejamento das ações de assistência social dos anos a seguir, algumas delas relacionadas especificamente com a população em situação de rua. Nesse sentido, a Prefeitura da cidade se soma aos movimentos sociais existentes que já prestavam algum tipo de auxilio à população de rua. Além disso, o governo local não inicia ações às cegas, a contagem foi a oportunidade para aproximar-se dessa população num nível empírico, longe de preconceitos e com base inicialmente nas informações dos moradores das áreas mais afetadas. Outros avanços sociais alcançados na década de 1990, foram a Lei da População de Rua (Lei nº 12.316/97) e o Estatuto da Criança e do Adolescente (Lei n 8.069/90). Resultado da mobilização tanto das entidades sociais, quanto dos moradores de rua, no processo destaca-se a participação da Vereadora Aldaíza Sposati. No caso da Lei da População de Rua. As ações do poder local apresentam continuidade, mas sem um eixo estratégico: o primeiro artigo indica que "o poder público municipal deve manter na cidade de São Paulo serviços e programas de atenção à população de rua".

Como o atendimento à população de rua tinha sido implantado há pouco tempo, procuraram-se parcerias com atores mais experientes; portanto a Lei impulsiona os convênios entre a Prefeitura e associações civis sem fins lucrativos. Procurou-se a complementaridade na prestação de serviços, pois naquele momento as associações civis possuíam mais experiência relacionada com a população em situação de rua que o pessoal do governo local. 
A Lei da População de Rua orienta os esforços para estabelecer lugares fixos de referência na cidade destinados à população em situação de rua, cujo objetivo é atingir as necessidades básicas que esses indivíduos não têm a possibilidade de satisfazer no contexto de rua. A lei se concentra em garantir os direitos dos moradores de rua, especificamente em relação à proteção contra práticas de discriminação e vexação.

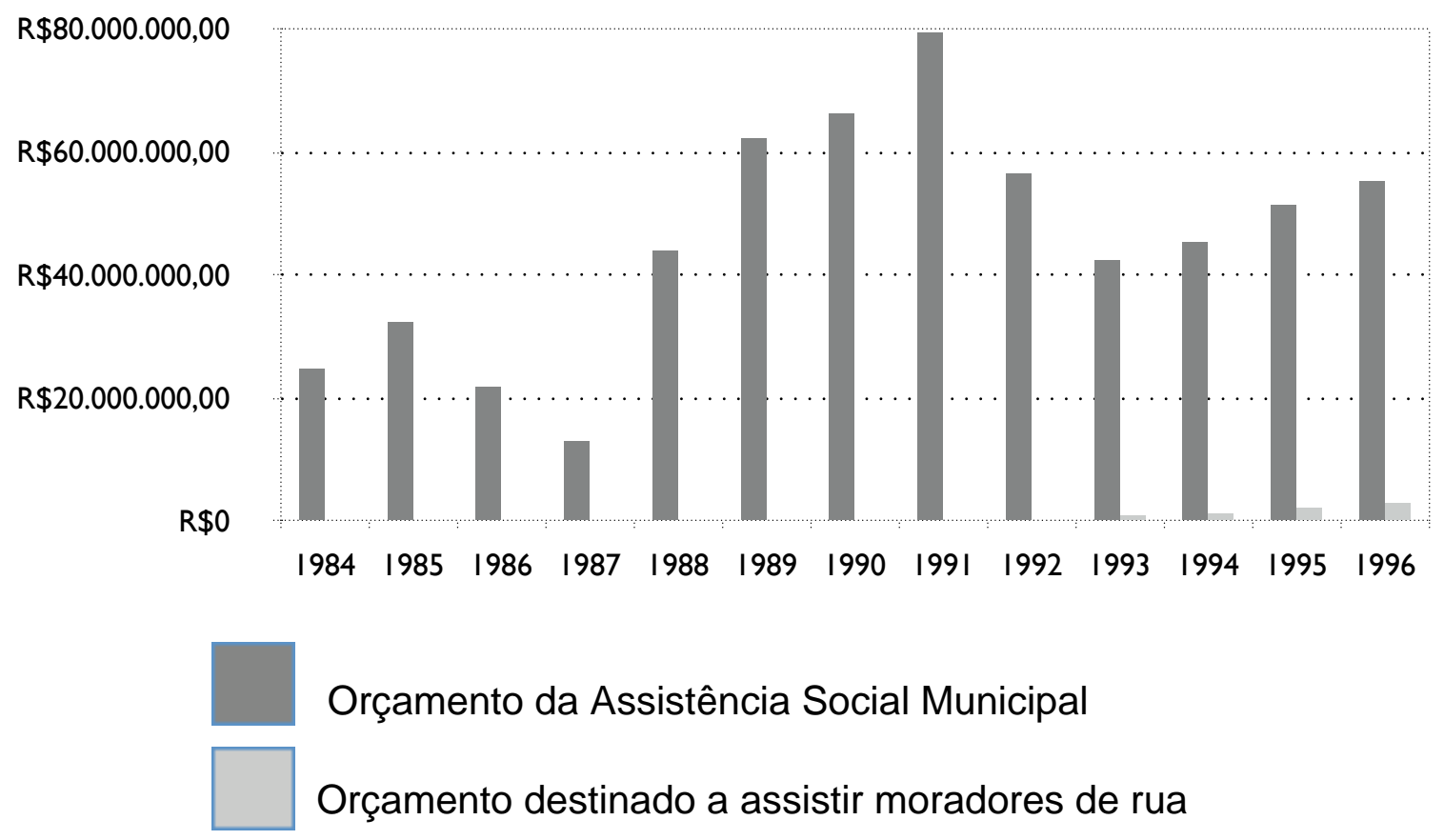

\section{Gráfico 6 - Orçamento de Assistência social 1984-1996}

Na década de 2000, os avanços na assistência social continuaram. Em relação ao governo local, um dos mais significativos foi a Lei de População de Rua (Decreto No 40.232). Após tudo o que foi alcançado com a lei anterior e a experiência acumulada pela equipe da Prefeitura, os esforços passaram a se concentrar no trabalho interdisciplinar e intersetorial dos órgãos municipais envolvidos com a política de atenção à população de rua. 
A lei designa de maneira direita as secretarias envolvidas no atendimento a essa população. Reconhece-se desse modo que o atendimento à população de rua precisa de mais um tipo de ator, pois assinala as secretarias da prefeitura envolvidas nas ações e mantém a política do trabalho em conjunto com a sociedade civil, já que as necessidades da população em situação de rua são múltiplas e simultâneas. Impulsiona-se, pela lei, a continuação das contagens na cidade, considerando-se aplicar metodologias alternativas a fim de captar a profundidade do fenômeno de rua, e o que é especialmente singular é a procura da distinção dos grupos etários dentro da população de rua nos censos. O papel do atendente do serviço social como um articulador entre o formal e o informal é ressaltado nos artigos, além de considerar o preparo psicológico que deve ter para realizar seu serviço. A Lei reflete, portanto, uma compreensão mais profunda do fenômeno de rua. Sem dúvida esse período (1993-2000) foi crucial para a Prefeitura; a Lei foi, portanto, uma consequência dessa experiência acumulada e da informação obtida das contagens. Considerando as três escalas (Federal, Estadual e Municipal), observou-se que, em 2001: 1) na escala Federal, não se registrou investimento nenhum; 2) na escala Estadual, o investimento foi de $\mathrm{R} \$ 210,00$, mas não era um montante gasto de maneira contínua já que não existiam programas Estaduais dirigidos especificamente à população em situação de rua, ou seja, eram gastos eventuais e não permanentes; 3) os governos municipais investiram entre $\mathrm{R} \$ 150,00$ e $\mathrm{R} \$ 200,00$ per capita nos programas de Atendimento à População de Rua (INSTITUTO PÓLIS / PUC, 2002, p. 23).

Na década de 2000, o panorama da população de rua em nível nacional ficaria esclarecido pela primeira Pesquisa Nacional de moradores de rua (PNMR). Essa 
pesquisa revelou São Paulo como a cidade com a maior população de moradores de rua (13.666), seguida pelo Rio de Janeiro (4.585) e por Salvador (3.289). Essa revelação sem dúvida afetou as políticas públicas da década, impulsionando ações concretas para atingir esse considerável número de população em risco. Em 2005 definiu-se o marco conceitual da Política Nacional de Assistência Social (PNAS) e criaram-se as bases para o Sistema Único de Assistência Social (SUAS). Isso introduz uma nova abordagem da assistência social, passando-se do conceito de atender uma população pobre ou necessitada a uma população vulnerável. Na escala municipal, como consequência, gera-se a Secretaria Municipal de Assistência e Desenvolvimento Social (SMADS), braço articulador da SUAS em escala menor. Essa entidade e o Instituto de Previdência Social definem vulnerabilidade como: "uma combinação de fatores que possam produzir uma deterioração" do nível de bem-estar do indivíduo em situação de vulnerabilidade e "em consequência de sua exposição a determinados tipos de riscos" (SMADS, 2010, p. 24).

Nas três escalas, Federal, Estadual e Municipal, a assistência social desenvolvese em três modalidades: atendimentos contínuos, eventuais e emergenciais. Ao concatená-las com o conceito multidimensional de "vulnerabilidade", amplia-se a abrangência do público que pode ser atendido. Em relação à população de rua, procuram-se novas formas de abordagem e prestação de serviços, além de se buscar a reabilitação e reinserção na sociedade dos indivíduos que se encontram nessa situação. O atendimento é oferecido tanto aos moradores de rua quanto aos indivíduos cuja fonte de subsistência se relaciona com "a rua", assinalando a importância do contexto para esses "segmentos populacionais (crianças, adolescentes e adultos) 
'desterritorializados' pelos intensos deslocamentos na cidade e na região metropolitana (...) em razão do enfraquecimento ou da ruptura de vínculos com a família, a escola, o trabalho e a comunidade em seus respectivos 'territórios'” (SMADS, 2010, p. 19).

O atendimento relacionado com os moradores de rua se desenvolve em três tipos de centros. Primeiro tipo: os Centros de Referência de Assistência Social (CRAS) oferecem proteção social básica destinada ao atendimento da população que apresenta maior grau de vulnerabilidade social e risco pessoal; por isso se localiza em áreas de vulnerabilidade social e se caracteriza por constituir um portal de ingresso à rede de proteção social do SUAS. A sua abordagem é preventiva. Os dois outros centros são parte da Coordenadoria de Assistência Social (CAS), cuja abrangência se relaciona com as prioridades de atendimento de cada perímetro designado da cidade de São Paulo. Segundo tipo: os Centros de Referência Especializados de Assistência Social (CREAS) formam parte da proteção social especial, oferecendo proteção social especial e especializada, cujo atendimento se destina aos serviços de proteção social de média complexidade. A sua abordagem é protetiva. Terceiro tipo: a Central de Atendimento Permanente e de Emergência (CAPE) forma parte da proteção social especial e constitui um equipamento complexo porque, embora tenha como foco o atendimento permanente à população em situações de emergência, também oferece atendimento em caso de eventual calamidade pública. Em relação à população de rua, o pessoal da CAPE é responsável pelas solicitações de atendimento a pessoas em situação de rua e pela central de vagas de acolhimento para adultos, crianças e adolescentes. As vagas para a população de rua são monitoradas pelo Sistema de Rua (SISRUA), uma base de dados relacionada com os moradores de rua; o acesso 
ao serviço é por meio da central telefônica da CAPE. Essa complexidade requer que seu período de funcionamento seja de 24 horas por dia.

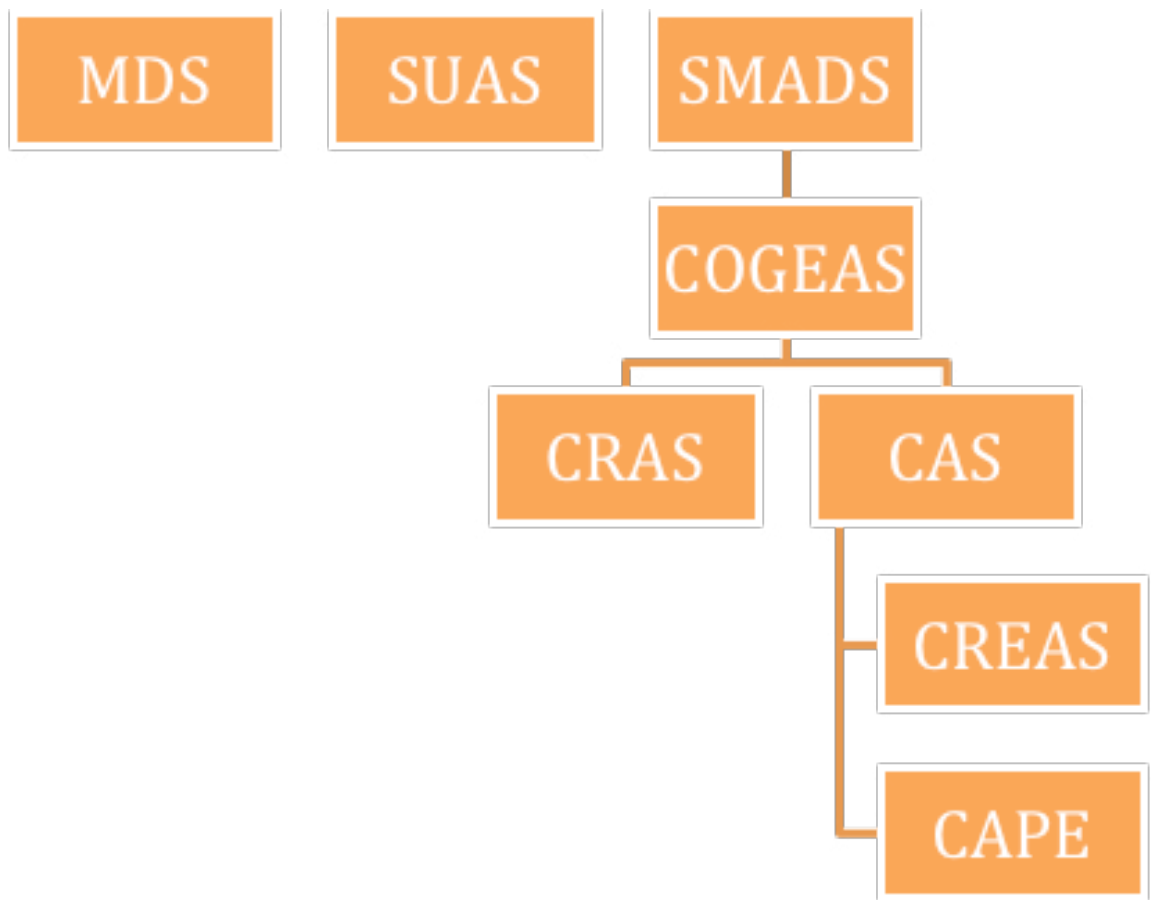

Gráfico 6 - Assistência Social na Cidade de São Paulo

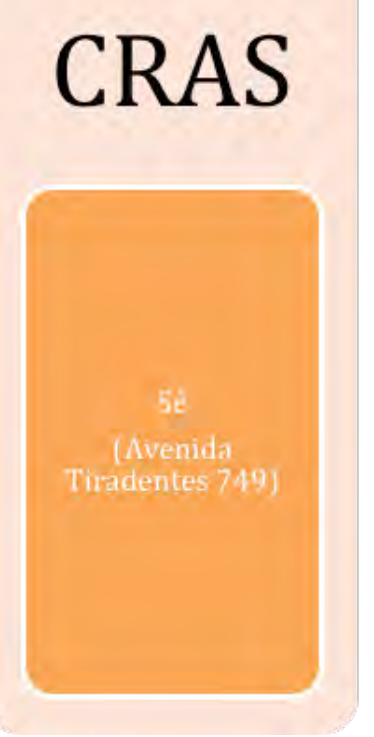

\section{CAS}

CREAS

CAPE

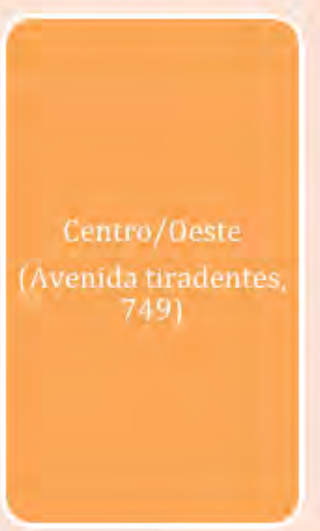
seuperiodo de funcionamento seja de 24 horas por dia. 
Em 2009 se definiram os conceitos da assistência social brasileira por meio da Tipificação Nacional dos Serviços Socioassistenciais; esta foi uma ação em grande escala, que esclareceu tanto o papel do Estado, quanto o direito do usuário em relação à assistência social. Nesse momento, definiu-se o atendimento para pessoas em situação de rua como um serviço de proteção social especial de média e alta complexidade, constituindo-se em um atendimento que se desenvolve com mais de um serviço. A natureza do fenômeno de rua exige mais de um serviço para atingir as diversas situações no contexto brasileiro; a variedade dos serviços relacionados com a situação de rua assinala que o Estado, em suas diversas instâncias, reconhece essa complexidade nas ações para abordar a problemática.

A fim de entender a tipificação, propõe-se aqui abordá-la de duas formas, primeiro em relação ao tipo de abordagem, segundo, em relação ao tipo de atendimento. A abordagem se desenvolve em duas modalidades: a assistência fixa e a móvel. Entende-se por assistência fixa como uma abordagem passiva: os serviços relacionados com o atendimento à população de rua têm uma sede, seja no CREAS ou em outro equipamento específico, como um abrigo, por exemplo. Além do local de atendimento, no caso da assistência fixa, é o interessado quem procura assistência. Nesse olhar, podem assinalar-se quatro tipo de serviços destinados à população de rua; na assistência fixa, encontra-se: a) serviço de proteção e atendimento especializado a famílias e indivíduos; b) serviço especializado para pessoas em situação de rua; c) serviço de acolhimento institucional; d) serviço de acolhimento em repúblicas. A assistência móvel da população de rua, por sua vez, constitui uma abordagem ativa que se desenvolve no espaço público. Diferentemente de sua contraparte fixa, na 
abordagem móvel, os atendentes é que identificam a problemática e procuram o indivíduo para encaminhá-lo a um atendimento do sistema de assistência social. As cidades do Brasil têm um tipo de atendimento à população de rua que pode ser definido como móvel / ativo. Na assistência móvel, encontra-se: e) serviço especializado em abordagem social.

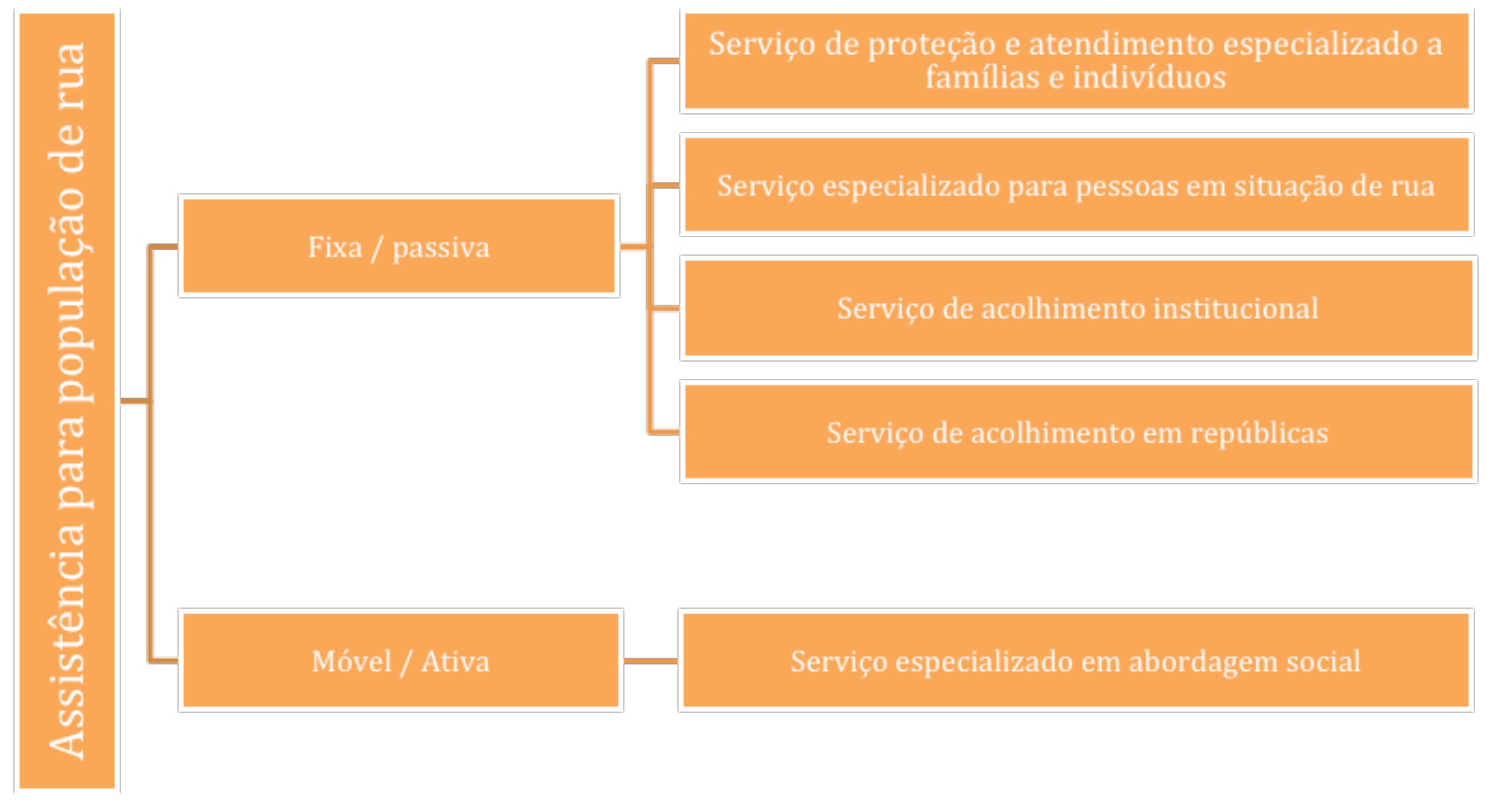

\section{Gráfico 8 - Modalidade de atendimento à população de rua segundo sua abordagem}

As diversas necessidades do atendimento à população em risco ou em situação de precariedade precisaram de uma diversidade de equipamentos que atingisse um alvo amplo em gênero, idade e problemáticas. A fim de esclarecer a relação entre os equipamentos identificados na Tipificação Nacional dos Serviços Socioassistenciais, destacam-se também duas modalidades em relação ao atendimento aos moradores de rua: o atendimento geral e o atendimento específico. No atendimento geral ou de ampla abrangência, identificam- 
se três tipos de atendimento que se relacionam com moradores de rua: a) serviço de proteção e atendimento especializado a famílias e indivíduos, b) serviço de acolhimento institucional e c) serviço de acolhimento em repúblicas. Nesse sentido, os moradores de rua compartilham o equipamento com outros usuários dos serviços de assistência social. Na segunda modalidade de atendimento de assistência social no Brasil, atende-se um público alvo específico ou reduzido; a equipe é especializada nos temas relacionados com a população de rua. Identificam-se dois tipos de serviços nessa modalidade: a) serviço especializado em abordagem social e b) serviço especializado para pessoas em situação de rua.

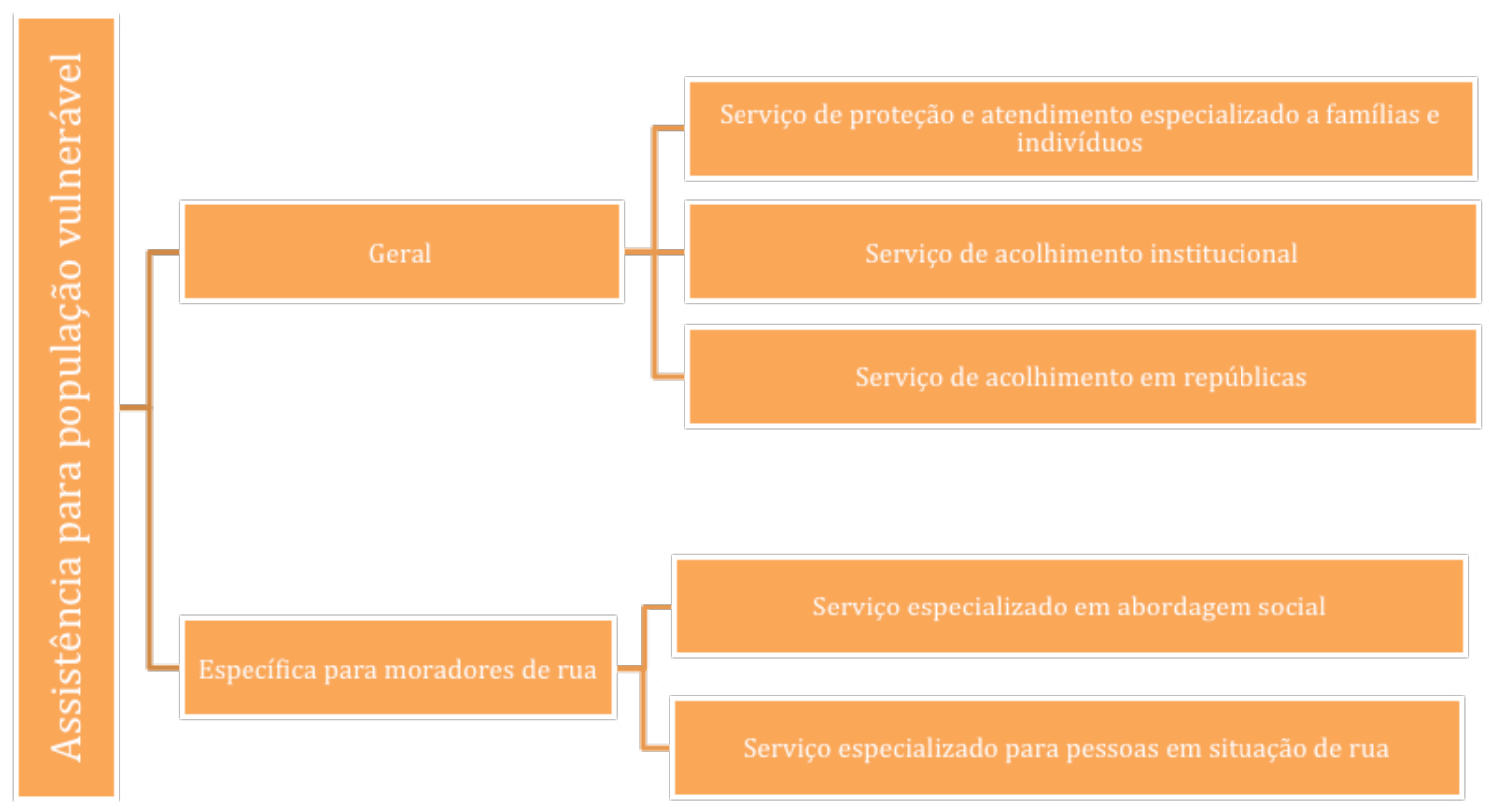

Gráfico 9 - Modalidade de atendimento à população de rua segundo a abrangência de seu alvo

É importante assinalar que o serviço especializado para pessoas em situação de rua é de caráter local e de complexidade média. Tem como alvo tanto as pessoas que utilizam as ruas como espaço de moradia, quanto os indivíduos cuja sobrevivência 
dependedostrabalhosinformaisquedesenvolvemnarua. Esseserviçofocaosindivíduos em situação de rua que têm mais tempo na rua, já que, além dos encaminhamentos aos outros serviços sócioassistenciais, atinge as condições individuais dos usuários a fim de orientá-los à reinserção à sociedade formal. Reconhecendo as necessidades das pessoas em situação de rua, os equipamentos relacionados com esse serviço possuem espaços de guarda de pertences, de higiene pessoal, de alimentação e provisão de documentação civil. Além disso, proporciona endereço institucional para utilização, como referência, do usuário e possibilita condições de acolhida na rede socioassistencial. Outro dos objetivos é vincular o indivíduo em situação de rua com sua família, já que, como se assinalou, a pessoa em situação de rua pode perder os vínculos com o núcleo familiar, o que dificulta a sua volta à sociedade formal. No serviço especializado em abordagem social, monitoram-se os espaços públicos da cidade à procura de situações irregulares ou de incidências criminosas nesse contexto, e atingem-se todos os indivíduos que utilizam os espaços públicos como forma de moradia e/ou sobrevivência. Os espaços monitorados devem ser considerados pontos de incidência de indivíduos em situação de rua. Os monitores desse serviço são orientadores socioeducativos e constituem os "olhos" do sistema de assistência social; para isso, eles desenvolvem geoprocessamento, georeferenciamento, monitoramento e seguimento das irregularidades que acontecem na rua.

Constitui este outro serviço de ampla abrangência em relação ao campo de ação e ao público-alvo, pois são muitos os espaços públicos, e é forte o trânsito de pedestres e veículos na cidade, além das dinâmicas urbanas relacionadas com esse contexto. Esse serviço aborda recém-chegados e indivíduos em situação crônica de rua; um dos 
objetivos é possibilitar a saída dessa condição, mas, até se conseguir a reinserção na sociedade formal, procura-se a resolução das necessidades imediatas. Outro dos objetivos é facilitar a assistência a esses indivíduos; é uma articulação entre o povo de rua e a assistência social, já que se encaminham à rede de serviços locais aqueles que precisem de atendimento. O trabalho dos orientadores é de suma importância, pois desenvolvem ações que possibilitam conhecer cada história de vida, priorizando a garantia do direito à convivência familiar e comunitária dos indivíduos em situação de rua. Seu funcionamento se relaciona estreitamente com o serviço especializado para pessoas em situação de rua.

Essa modalidade de atendimento é flexível, já que oferece abordagem social à pessoa em situação de rua encaminhada por terceiros, seja mediante solicitação de munícipes, órgãos governamentais e não governamentais, ofertando, principalmente, vagas de atendimento na rede socioassistencial. $\mathrm{O}$ atendimento também apresenta flexibilidade em relação ao território monitorado e ao alvo, pois em algumas áreas da cidade o atendimento urbano se limita à população de rua em geral, e em outras por grupo etário, o que quer dizer que dois ou mais grupos atendem o mesmo território, mas uns visam ao atendimento de adultos e outros, de crianças, adolescentes e idosos. O objetivo é cobrir as necessidades específicas de cada território. serviço de proteção e atendimento especializado a famílias e indivíduos (PAEFI), classificado como de complexidade média, atinge tanto o indivíduo quanto o seu núcleo familiar, que, por razões alheias, se vêm forçados a morar na rua. Constitui um serviço que provê acolhimento e assistência a uma ampla variedade de pessoas, em diferentes circunstâncias e de diversos grupos etários. Em essência, constitui 
um atendimento pensado para aqueles que recém-chegaram à rua, seja a sós ou em grupo, por isso é um serviço de ampla abrangência em relação à garantia dos direitos dos indivíduos atendidos e aos programas a que eles têm acesso. Preveem-se as diversas circunstâncias súbitas e adversas que levam os indivíduos ou grupos à rua: violência física, psicológica ou sexual, o afastamento forçado do convívio familiar e outras formas de violação de direitos das pessoas. O equipamento relacionado com esse serviço é o Centro de Referência Especializado de Assistência Social (CREAS), funcionando de segunda a sexta-feira durante o dia.

A fim de garantir a proteção integral de indivíduos e/ou núcleos familiares, cria-se o serviço de acolhimento institucional. Mesmo prestando atendimento a grupos que variam em número, idade, raça e até religião, um dos objetivos desse serviço é o respeito aos seus costumes, por isso se promove um atendimento de pequenos grupos nessa modalidade de assistência social. A unidade está pensada para funcionar inserida num contexto comunitário, assemelhando-se a um ambiente familiar. O atendimento se divide de acordo com os grupos etários (crianças, jovens, adultos e idosos), gênero (mulheres ou homens) e dos indivíduos atendidos (adultos ou famílias). Embora o público-alvo seja amplo, à medida que os indivíduos são atendidos, encaminham-se a um equipamento especializado relacionado com sua problemática, exemplo disso é o atendimento às mulheres em situação de violência. Esse serviço também se relaciona com os idosos em condição de rua, pois provê um espaço de acolhimento com até 10 vagas, um espaço em que são atendidos por pessoal habilitado, treinado e supervisionado por uma equipe técnica capacitada. Em todos os casos, por ser um serviço relacionado com a população em risco e de alta complexidade, procura-se 
a salvaguarda da sua identidade, integridade e dignidade; no final do processo iniciado nesse serviço, o usuário é encaminhado a um equipamento especializado como Casa Lar, Abrigo Institucional, Casa de Passagem ou Residências Inclusivas. O Serviço de acolhimento em repúblicas se concentra nos jovens e adultos que estão em uma situação de vulnerabilidade ou risco pessoal e social, aqueles que precisam de assistência para construir e fortalecer os vínculos familiares e comunitários; exemplo disso são os indivíduos em processo de saída das ruas. Esses equipamentos possuem o material e o pessoal necessários para incentivar a autonomia individual, familiar e social dos usuários atendidos. Tanto o atendimento especializado fixo quanto o móvel podem encaminhar os indivíduos em condição de rua a esses equipamentos que funcionam 24 horas. As repúblicas de dividem por gênero e grupo etário (jovens, adultos e idosos.

\subsubsection{OS EQUIPAMENTOS PARA PESSOAS EM SITUAÇÃO DE RUA}

Nos equipamentos relacionados com os moradores de rua, aplicam-se certas restrições em relação ao seu uso; medidas que, em teoria, colocam os espaços de assistência em oposição à vida de rua, pois nesta os moradores possuem uma liberdade plena. Embora na área central da cidade se localizem muitos equipamentos de apoio assistencial relacionados com o povo da rua, alguns dos moradores de rua nessa área não usam o equipamento assistencial, devido à "falta de liberdade, horários, proibição do uso de álcool e drogas", pois para a população de rua essas restrições constituem um problema (QUIROGA / RODRIGUEZ -org-, 2009, p. 139). 
Outra das restrições se relaciona à permanência nos espaços, pois "nessas instituições, além do prazo restrito para a permanência, a sistemática de funcionamento e controle faz com que muitas pessoas desabrigadas prefiram a rua, em função do caráter disciplinador e repressivo de alguns desses lugares". Os equipamentos trabalham regularmente de segunda a sexta-feira e alguns atuam no horário noturno; nestes, os moradores de rua ingressam à noite e saem de manhã de volta à rua (VIEIRA / BEZERRA / ROSA, 1992, p. 80).

Em relação ao funcionamento do equipamento ao longo do ano, durante as frentes frias as vagas previstas não conseguem atingir a maioria da população, que, mesmo sabendo das restrições, procuram acolhimento nas noites mais frias. Os "dados sugerem uma significativa falta de vagas em relação à demanda efetiva existente nos municípios" no Brasil (QUIROGA / RODRIGUEZ -org-, 2009, p. 91).

As faixas etárias dos moradores de rua que procuram acolhimento variam em relação ao uso dos equipamentos; é um fato que na população de rua predominam os homens, mesmo assim "a distribuição etária das mulheres é diferente da dos homens e varia em função do serviço pesquisado" (VIEIRA / BEZERRA / ROSA, 1992, p. 64).

A cidade de São Paulo possui uma ampla variedade de equipamentos de assistência social, os que se concentram nos moradores de rua oferecem apoio especializado e específico. Essa variedade de equipamentos atinge os diferentes perfis de morador de rua, alguns oferecem o mesmo apoio, por exemplo o pernoite, mas a variação na localização e no horário faz com que sejam procurados por diferentes tipos de indivíduos em situação de rua; à medida que as pesquisas revelam as características 
dos frequentadores dos equipamentos, pode-se entender como gradativamente 0 indivíduo em condição de rua vai de um equipamento ao outro. Em poucas palavras: existe um equipamento para cada estágio na vida de rua, desde os recém-chegados até aqueles que conseguem sair da rua e reinserir-se na sociedade formal. Além da assistência dada aos moradores de rua, os equipamentos de assistência social constituem uma valiosa fonte de dados. Os pesquisadores que estudaram o fenômeno de rua procuraram nos arquivos das instituições públicas e privadas a fim de obter mais dados da população em questão. Algumas das informações eram vagas, devido ao fato de esses equipamentos atingirem um público-alvo amplo, seja moradores de rua, migrantes ou indivíduos que circunstancialmente passam por uma situação de desabrigo (SIMÕES, 1992, p. 35).

No caso das pesquisas relacionadas com os moradores de rua, além desses espaços de assistência social, "procurou-se informação em outras instituições que recebem pessoas em situação de rua, como é o caso de hospitais e clínicas, ou mesmo casas de convivência" (QUIROGA / RODRIGUEZ -org-, 2009, p. 20).

Alguns dos espaços de assistência social constituem o produto das parcerias público-privado, já que muitas ONGs colaboram com subsídios, sejam Igrejas, sejam organizações filantrópicas privadas. As propostas de assistência das ONGs se relacionam com formas auto-organizadas a partir das quais essa população viabilize projetos relacionados com a geração de renda; o melhor exemplo disso são as comunidades de catadores de papel e papelão que receberam apoio das ONGs. A mensagem fundamental que transmitem essas instituições é a possibilidade de sair 
da vida de rua e a "superação da condição de penúria para quem se encontra na rua" (SIMÕES, 1992, p. 5).

Mesmo oferecendo apoios semelhantes, o que pode ser confuso para os pesquisadores, podem classificar-se três tipos de equipamentos. O primeiro se concentra no pernoite, porém só funciona durante as noites de segunda a sexta-feira. À medida que o indivíduo em situação de rua transita por tais equipamentos, gradativamente se insere num programa de moradia periódica ou permanente. O segundo tipo de equipamento oferece apoios emergenciais relacionados a saúde, bem-estar, alimentação e emprego; funciona na jornada diurna. O terceiro tipo é voltado para a reinserção na sociedade civil dos indivíduos em situação de rua; mesmo que o núcleo das ações seja o emprego, esses centros se apoiam nos equipamentos de moradia para acompanhar o indivíduo nessa difícil transição,

\subsubsection{EQUIPAMENTOS DE PERNOITE}

Deve entender-se que o tempo na rua nem sempre faz diferença nas escolhas de lugares de pernoite, sejam pagos ou gratuitos; são as circunstâncias pessoais que determinam a escolha do espaço de pernoite. Nota-se que muitos dos equipamentos parecem extremamente similares, mas seus objetivos específicos orientam o atendimento em cada um, em relação a isso diferenciam-se pelos dias e horários de atendimento, pelo número de acolhidos que podem albergar e pela localização (VIEIRA / BEZERRA / ROSA, 1992, p. 80). 
O primeiro equipamento conferido pela maioria dos recém-chegados à rua é o albergue, também conhecido como centro de acolhida às pessoas em situação de rua. Inicialmente acolhiam especificamente moradores de rua no período do inverno ou em caso de emergências. Em 2001, a Lei de População de Rua especifica que devem atender até cem (100) pessoas por unidade. Em relação a seu funcionamento, essa lei também possibilita a participação das associações civis, além disso o atendimento dos abrigos especiais abrange a partir de então uma população em situação de precariedade ou vulnerabilidade, quer dizer que não são exclusivos dos moradores de rua. Ao ter atualmente um público-alvo amplo, eles são favorecidos com muitos investimentos em nível nacional, pois constituem um apoio para a população em risco (QUIROGA / RODRIGUEZ -org-, 2009, p. 139).

É um espaço temporário para a higiene pessoal, alimentação, vestuário, guarda de volumes e serviços de referência aos moradores de rua. O funcionamento se desenvolve em duas modalidades: a primeira acolhe adultos por 16 horas e a segunda por 24 horas; as vagas são distribuídas em função da vulnerabilidade do atendido. Há também os albergues especiais, que funcionam apenas temporariamente, na época do inverno ou de frentes frias, relacionando-se com medidas de contingência da Prefeitura, como resposta ao significativo déficit de vagas nas temporadas críticas. Constituem instalações com provisões prontas para atender emergências, esses centros de acolhida especial se concentram nos públicos que requerem atendimento diferenciado seja pelo tipo de atendimento ou pela temporada. A maioria dos usuários nos albergues são adultos, com mais de quarenta anos, que se acham temporariamente em situação de rua, por exemplo "mulheres com filhos, que não têm para onde ir", que 
são recém-chegadas à rua e que procuraram posteriormente amparo com a família ou amigos. Os albergues de inverno se caracterizam por receber principalmente "recémchegados" (VIEIRA / BEZERRA / ROSA, 1992, p. 62, 64).

Os moradores de rua que frequentam albergues são, em sua maioria, do perfil 2 (o desempregado sem teto) de recém-ingresso à vida de rua. Os estudos assinalam a predominância de empregos temporários entre os indivíduos que procuram esse tipo de equipamento - a maioria desenvolve trabalhos na construção civil e áreas afins. Provavelmente esses indivíduos se acham em um período laboral inativo ou entre empregos. As pesquisas indicam que são poucos os usuários de albergues que desenvolvem uma estratégia de subsistência relacionada com a vida de rua ou estão em condição crônica (VIEIRA / BEZERRA / ROSA, 1992, p. 82-83).

Dentre os acolhidos nos albergues, poucos passaram por outras alternativas de acolhimento antes de chegar até aí; sua inserção à vida de rua não foi imediata, pois passaram por cortiços e pensões. Os estudos revelam que "a maioria esteve anteriormente em trânsito permanente entre as várias alternativas", o que indica que um número reduzido veio de casa alugada ou própria (VIEIRA / BEZERRA / ROSA, 1992, p. 80).

Daqueles que "manifestaram preferência por dormir em albergue, 69,3\% apontaram a violência como o principal motivo da não preferência por dormir na rua, seguido pelo desconforto $(45,2 \%)$ ". São os dependentes químicos que manifestam "a preferência pela permanência na rua em detrimento dos albergues", isso em parte pela regra que os albergues impõem aos seus frequentadores 
de abstinência do uso de substâncias ilícitas em suas dependências, razão pela qual eles se afastam (QUIROGA / RODRIGUEZ -org-, 2009, p. 91-92).

Mesmo que ofereça espaços para o pernoite, constitui um equipamento procurado para a higiene pessoal por alguns moradores de rua; lamentavelmente a maioria utiliza a própria rua para a sua higiene pessoal e para as suas necessidades fisiológicas, seguido pela minoria que utiliza as casas de parentes ou amigos para esse propósito. Outro equipamento de assistência para o pernoite dessa população são os abrigos. Seu funcionamento é permanente e adicional ao pernoite destinado a seus usuários, o abrigo fornece condições de higiene pessoal, alimentação, guarda de volumes, serviços de documentação e referência na cidade. O tipo de morador de rua atendido varia, já que os abrigos não acolhem somente recém-chegados, também aqueles que têm uma permanência longa na rua chegam até esses centros: "nos abrigos predominam os que são mais recentes na rua: 54\% estão aí há menos de seis meses, e 17\% há menos de um mês". Alguns dos moradores de rua em condição crônica também procuram abrigos, "40\% dos homens e $30 \%$ das mulheres" (VIEIRA / BEZERRA / ROSA, 1992, p. 76).

Conveniadas com a Prefeitura, as Casas de Convivência, conhecidas também como núcleos de convivência para adultos em situação de rua, concentram-se em promover a convivência e socialização entre os moradores de rua, oferecendo atividades ocupacionais, educacionais e culturais focadas em sua reinserção. Conceberamse como um espaço de lazer; em teoria, constituem um espaço para promover atividades diversas que contribuam à saúde mental da população em situação de 
rua, complementando isso com serviços de banho, barba e lavagem de roupas, alimentação, vestuário, guarda-volumes, serviços de documentação e referência na cidade. Distinguem-se do resto do equipamento por seus objetivos específicos e porque funcionam oito horas por dia, sete dias por semana. Esses espaços de convivência são frequentados por moradores de rua que ainda não se acham em uma condição crônica, mas, por já estarem a certo tempo nessa circunstância (a maioria entre seis meses e um ano e meio na rua), já conhecem muito da vida na rua seja pela própria experiência ou pelas experiências de outros moradores de rua. Por isso, é um espaço para aqueles que já conhecem os lugares de acolhida, aqueles que sabem de que equipamento precisam em certas circunstâncias, por isso constitui um espaço de trânsito. O que quer dizer que nem todos os usuários desses espaços os frequentam regularmente; ao redor de 20\% dos usuários das Casas de Convivência pernoitam nesse equipamento frequentemente. Por exemplo, estudos revelam que muitas das mulheres jovens que frequentam esse espaço já passaram pela Fundação Estadual para o Bem Estar do Menor (FEBEM) (VIEIRA / BEZERRA / ROSA, 1992, p. 62, 64, 76, 80).

Alguns dos frequentadores das Casas de Convivência desenvolvem estratégias de sobrevivência relacionadas com a vida de rua (carregador de jornal, catador de papelão, guardador de carros, etc.), o que reforça a ideia de que eles têm mais tempo na rua, diferentemente dos frequentadores de abrigos e albergues. Existem vagas de abrigo e recuperação, que constituem espaços de atendimento focados aos moradores de rua que padecem de alguma doença física que precise de atendimento médico permanente (VIEIRA / BEZERRA / ROSA, 1992, p. 83). 
As moradias provisórias constituem um estágio focado na reinserção dos indivíduos em condição de rua. No processo de reinserção, a moradia constitui um elemento essencial, especialmente em relação à população de rua. A partir do ano 2001, a Secretaria de Habitação (SEHAB) participou em conjunto com a Secretaria de Assunto Sociais (SAS) na promoção desses espaços de moradia. As Moradias Provisórias são de caráter temporário, pois se espera encaminhar ao indivíduo a conseguir sua própria moradia. Esses espaços têm a capacidade de albergar até 15 pessoas, apresentadas como um estágio breve no processo de reinserção social. Constituem locais próprios ou locados pela Prefeitura, aos quais os moradores de rua que passam por uma série de avaliações podem recorrer, mesmo assim é o Poder Público o encarregado de manter essas instalações físicas. As soluções habitacionais definitivas são o estágio final da reinserção dos moradores de rua, relacionadas com o processo focado na recuperação das condições formais de moradia dessa população. Constituem um auxílio de moradia e financiamento de construções em regime de mutirão. São opções de moradia pensadas especificamente para a população nesse processo. Esse constitui o último passo no processo de reinserção em que o indivíduo em situação de rua é acompanhado pelo pessoal da Prefeitura da cidade.

A Prefeitura oferece um apoio para os indivíduos recém-chegados à rua que, embora tenham condições de fazer a gestão cotidiana de sua vida, ainda não possuem condições financeiras para suprir sua moradia. Oferecem-se vagas na rede de hotéis e pensões para essas pessoas; o pessoal dos CREAS acompanha cada indivíduo até que alcancem a autonomia financeira e obtenham uma moradia independente. $\mathrm{O}$ tempo máximo de utilização do serviço é de 3 meses. 
Outro equipamento relacionado com os moradores de rua, mas especializado, é o abrigo especial para catadores. O perfil do usuário desse equipamento é o indivíduo com mais de 18 anos que possui carroça e tem como prática a catação de materiais recicláveis. As instalações estão prontas para receber as pessoas em situação de rua que possuam carroças, cachorros e material catado. O funcionamento é de segunda a segunda, 24 horas.

\subsubsection{EQUIPAMENTOS DE APOIO PARA A VIDA NA RUA}

Em relação ao segundo tipo de equipamento assistencial, o indivíduo recém-chegado achará com facilidade os Centros de Serviços, locais fixos com recurso humano e material de apoio concebido para o atendimento diurno aos moradores de rua. O que é oferecido é amplo, incluindo espaços para higiene pessoal, cuidados ambulatórios básicos, serviços de referência na cidade. Um dos espaços que os distinguem são os estacionamentos de "carrinhos" e "carroças", equipamento necessário para alguns moradores de rua. Os Plantões constituem um equipamento relacionado com pessoas em situação de rua ou pessoas em situação de risco que precisem de atendimento prioritário. Usualmente assistem pessoas que se acham circunstancialmente na rua. Abrangem um território amplo, constituído muitas vezes por mais de uma Subprefeitura (VIEIRA / BEZERRA / ROSA, 1992, p. 62).

Sendo seu alvo a população de rua de diversos perfis, os estudos realizados nos Plantões revelam que em sua maioria os frequentadores desse equipamento perderam sua residência pelo desemprego $(31,8 \%)$, seguido por problemas familiares 
$(22,7 \%)$, insuficiência de renda $(18,2 \%)$ e término de obra $(25,9 \%)$ - no caso dos que trabalhavam na construção civil (VIEIRA / BEZERRA / ROSA, 1992, p. 76-79).

Nos Plantões se registra o atendimento de pessoas recém-chegadas à cidade e de recente ingresso na vida de rua, já que vêm a São Paulo na procura de oportunidades de emprego. Na maioria dos casos, mesmo nessas circunstâncias, os recém-chegados à cidade declararam a intenção de permanecer nesse centro com a esperança de inserir-se no mercado de trabalho (VIEIRA / BEZERRA / ROSA, 1992, p. 87).

Os Bagageiros são instalações destinadas à guarda provisória de pertences pessoais. Mesmo que seu objetivo principal seja apoiar os moradores na vida de rua, oferecem auxílio no processo de reinserção por meio do acompanhamento social. O equipamento é frequentado por moradores de rua adultos, funciona de segunda a segunda, 12 horas por dia. Os moradores de rua gravitam ao redor de instituições que ofereçam comida substanciosa e mais próxima de sua vivência cultural. Em relação à alimentação, as Bocas de Rango e os restaurantes comunitários são frequentados pela população em situação de rua e pelas pessoas de baixa renda. Os primeiros são locais de distribuição gratuita de comida, realizada predominantemente em espaços públicos, por exemplo o Largo de São Francisco. Concentram-se no centro da cidade, na maioria das vezes nos fins de semana e durante as frentes frias; são feitas por instituições filantrópicas de caráter assistencial. Os restaurantes comunitários são outra opção relacionada com alimentação, geralmente o povo de rua sabe dos cardápios e horários das instituições. Distribuem comida a baixo custo; a ideia é apresentar uma oferta de alimentação básica, nutritiva e barata, o que incentiva a muitos moradores de rua a implementar alguma estratégia de subsistência para obter alimentos. 
O projeto "Restaurante Popular Bom Prato" funciona em escala estadual, em parceria com as prefeituras; é, de todos os restaurantes comunitários, o mais conhecido e consiste em uma rede de restaurantes populares com uma oferta de refeições balanceadas e de qualidade a baixo custo (de $R \$ 0,50$ a $R \$ 1,00$ ). Funcionam durante o dia, oferecem café da manhã e almoço; além disso, oferecem cursos na área de alimentos e internet para seus usuários. No primeiro censo dos moradores de rua em São Paulo, identificaram-se 26 locais de distribuição de alimentos com diferentes modalidades de funcionamento, a maioria localizados no centro da cidade; poucos foram os casos de locais em áreas mais nobres da cidade fora do centro. A Igreja do Senhor dos Passos e a Federação Espírita são outras opções de locais onde os moradores de rua podem obter alimentos gratuitos. Na reflexões do primeiro censo, também assinala-se a coincidência entre os pontos de distribuição de alimentos e os locais escolhidos para pernoite dos moradores de rua.

\subsubsection{EQUIPAMENTO DE APOIO PARA A REINSERÇÃO}

No terceiro tipo de equipamento se oferecem atividades que apoiam as diferentes modalidades de reinserção à sociedade formal, sejam esforços coletivos ou individuais. Criaram-se os núcleos de inserção produtiva, a fim de promover a autonomia dos usuários por meio de orientação seja laboral ou de projetos sustentáveis; estabeleceramse oficinas e cooperativas de trabalho para incentivar as comunidades produtivas. "O esforço da maioria das entidades dirige-se para a geração de renda, mas de pouca eficiência, como as oficinas de artesanato que, mesmo bem-feitos, não competem com os produtos importados" (SAEKO / SANTOS, 2006, p. 151). 
Tendo como objetivo estabelecer um espaço para a reinserção social, no qual o indivíduo em situação de rua tenha um apoio em relação à capacitação profissional, a encaminhamento a empregos e à formação de cooperativas às quais os moradores de rua podem se associar para gerar renda, criaram-se os centros de capacitação técnica para adultos em situação de rua. Em relação às frentes de trabalho na cidade, "o emprego temporário de um salário mínimo dos governos, é uma proposta emergencial utilizada principalmente na cidade de São Paulo", reconhecendo assim a necessidade de uma parte da população que não possui um trabalho regular (SAEKO / SANTOS, 2006, p. 151).

A Prefeitura possui instalações especializadas com equipamentos relacionados com a geração de renda que auxiliam os moradores de rua a desenvolverem habilidades com vistas à conquista de empregabilidade, autonomia e inserção social. O funcionamento desses equipamentos é de segunda a sexta-feira, das 8 às 17 horas. Tem como público pessoas adultas de ambos os sexos procedentes da rede socioassistencial. 
CAPITULO 5
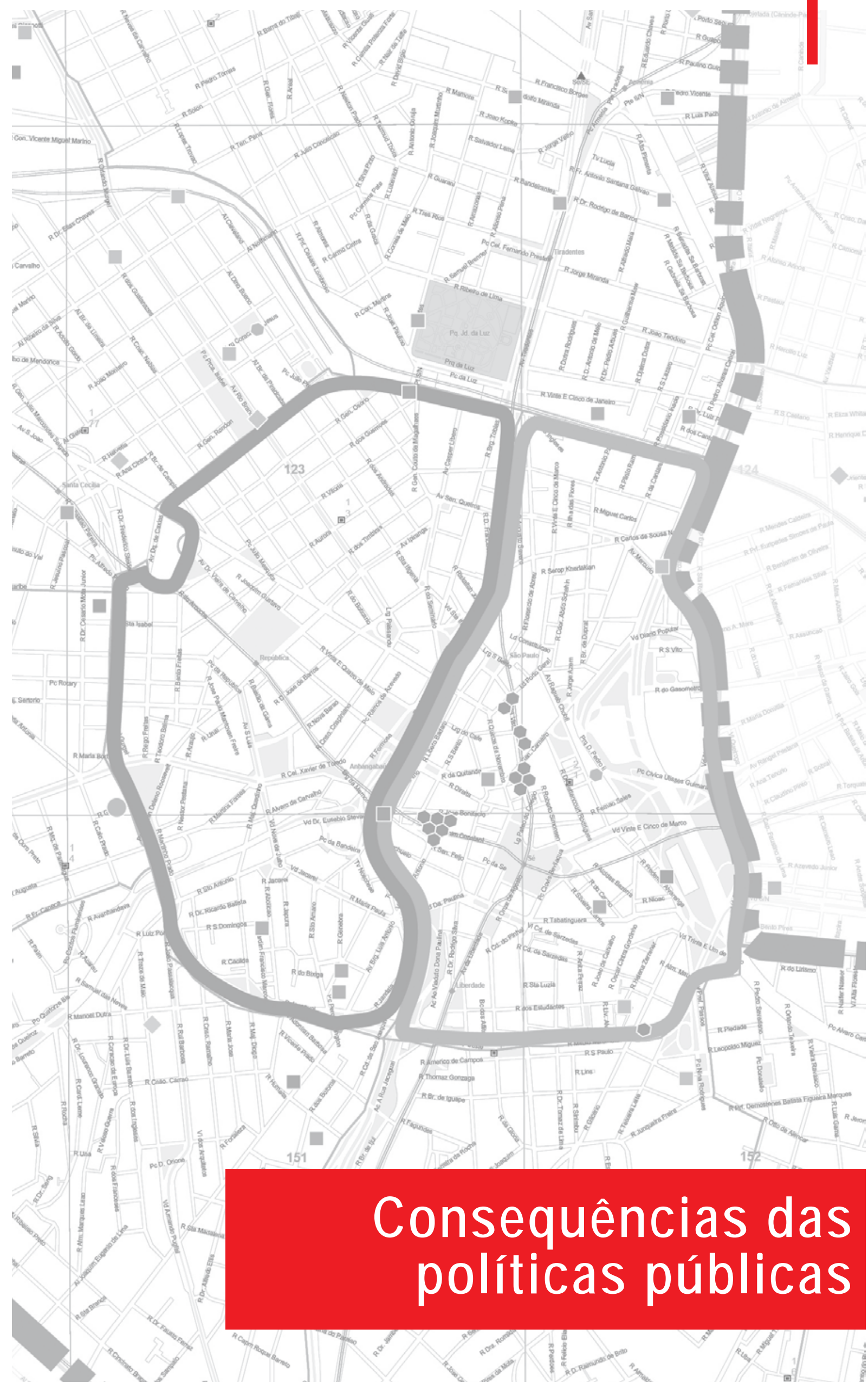

\&.

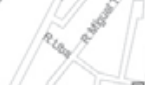


Anteriormente à análise da população de rua, precisa-se explorar o contexto da moradia no centro da cidade e como algumas das ações da Prefeitura da cidade de São Paulo o influenciaram. É importante estabelecer o período em que se inicia o êxodo de moradores do centro da cidade - que proporcionou a tomada desses bairros esvaziados por parte de outros atores, sendo um deles os moradores de rua - e também estabelecer a volta dos residentes ao centro da cidade, como consequência das ações da Prefeitura - elas tiveram o efeito desejado, pois o interesse por morar no centro surgiu de novo, mesmo que não tenha sido com a velocidade desejada pelas autoridades locais.

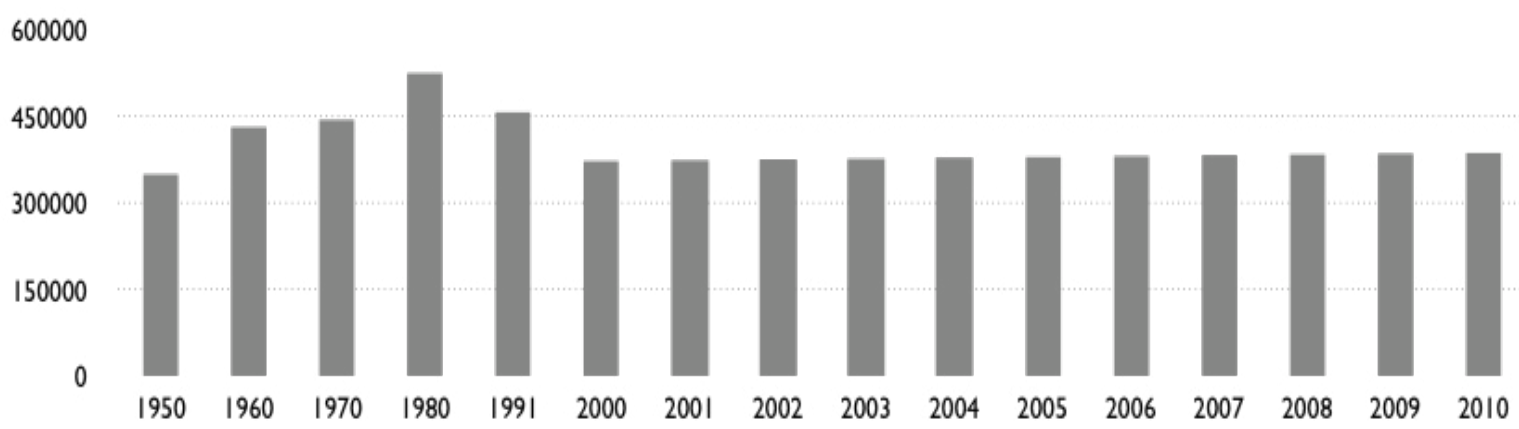

Gráfico 11 - População da Subprefeitura Sé 1950-2010

\subsection{O PANORAMA DA MORADIA NO CENTRO}

A população da Subprefeitura Sé apresenta variações nos últimos 50 anos; observamse três períodos significativos: Primeiro, de 1950 até 1980 há um aumento da população na Subprefeitura Sé, chegando ao auge em 1980. Nesse período, a cidade de São Paulo torna-se um centro de tomada de decisões do país, deixando o caráter industrial para trás. É nessa época que a cidade se torna uma metrópole. De 1980 até 
2000, observa-se um declínio da população; isso coincide com a deterioração da área. Os primeiros esforços de requalificação do centro histórico da cidade parecem não ter sido eficazes em reter residentes, pois nesse período as pessoas saem da área procurando outras opções de moradia. O terceiro período, de 2000 até 2010, apresenta um aumento contínuo e lento, mas as cifras não alcançam a concentração de população do território em 1980. Para essa área da cidade, este é um período significativo, pois nele foi criada a Subprefeitura Sé.

Em 2001, os esforços de requalificação canalizam-se por meio do PROCENTRO, com o Plano de Reconstrução do Centro (PRC). O PRC constitui-se de 8 programas: Programa Andar no Centro, Programa Morar no Centro, Programa Trabalhar no Centro, Programa Descobrir o Centro, Programa Preservar o Centro, Programa Investir no Centro, Programa Cuidar do Centro, Programa Governar o Centro. Esse programa "visava a aproveitar edifícios abandonados, em estado avançado de degradação ou ocupados por movimentos populares ligados às lideranças dos sem-teto para reforma ou construção de habitações populares" (CARDOSO, 2007, p. 2).

Um ano após sua criação, o PRC foi extinto. O problema da moradia na Área Central foi retomado em 2004 pela Secretaria de Habitação (Sehab). Os objetivos se definem: melhorar as condições de vida dos moradores do Centro; viabilizar moradia adequada para pessoas que moram ou trabalham na região; evitar o processo de expulsão da população mais pobre, o que muitas vezes ocorre em políticas de reabilitação de centros urbanos. 
As ações focariam na reforma de prédios vazios, combinando soluções habitacionais com iniciativas de geração de renda e procurando nesse processo a diversidade social. Mesmo que a partir de 2001 se tenha apresentado uma descontinuidade das ações e atores da Prefeitura, e que os resultados das ações do governo local ainda não possam ser contabilizados na sua totalidade, as políticas públicas em relação a locais de moradia em escala nacional e local conseguem reter residentes na área.

A curva de crescimento da população nos distritos que se vê na tabela $V$ é quase um padrão generalizado na Subprefeitura Sé, pois os distritos de Bela Vista, Consolação, Liberdade, República e Santa Cecília não apresentam esvaziamentos fortes, mantendo uma porcentagem fixa de residentes. O crescimento da população após 2000 apresenta-se constante, o que comprova que esses distritos se consolidaram como residenciais. Os cinco distritos alcançaram, nesta última década, um número de moradores que supera o número da população total da cidade na década de 1950. Alguns hoje se apresentam como uma opção de moradia no centro da cidade, no caso de Consolação e Santa Cecília, para um público bem definido, classe média alta e média respectivamente. Dos oito bairros que constituem a Subprefeitura Sé, três apresentam um padrão de concentração de população fora do generalizado na área. São Bom Retiro, Sé e Cambuci os distritos que perderam moradores sem conseguir recuperá-los nas últimas décadas, apesar das políticas públicas locais de moradia, apresentando padrões irregulares em seu crescimento populacional. Após o declive populacional, neles predominariam os usos terciários. 


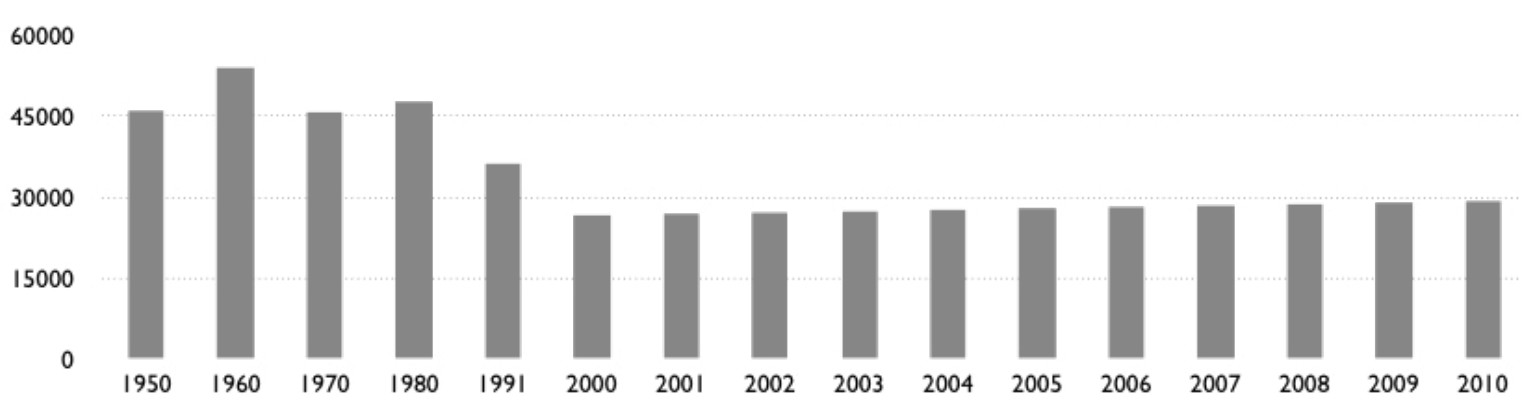

Gráfico 12 - População do bairro Bom Retiro 1950-2010

No caso do Bom Retiro, a década entre 1950 e 1960 apresenta um aumento da população; na década seguinte, a população cai, para subir de novo entre 1970 e 1980, para baixar até 1991. A partir de 2000, alcança o ponto mais baixo de população, e inicia-se então um aumento constante, mas que não se aproxima das quantidades das décadas anteriores.

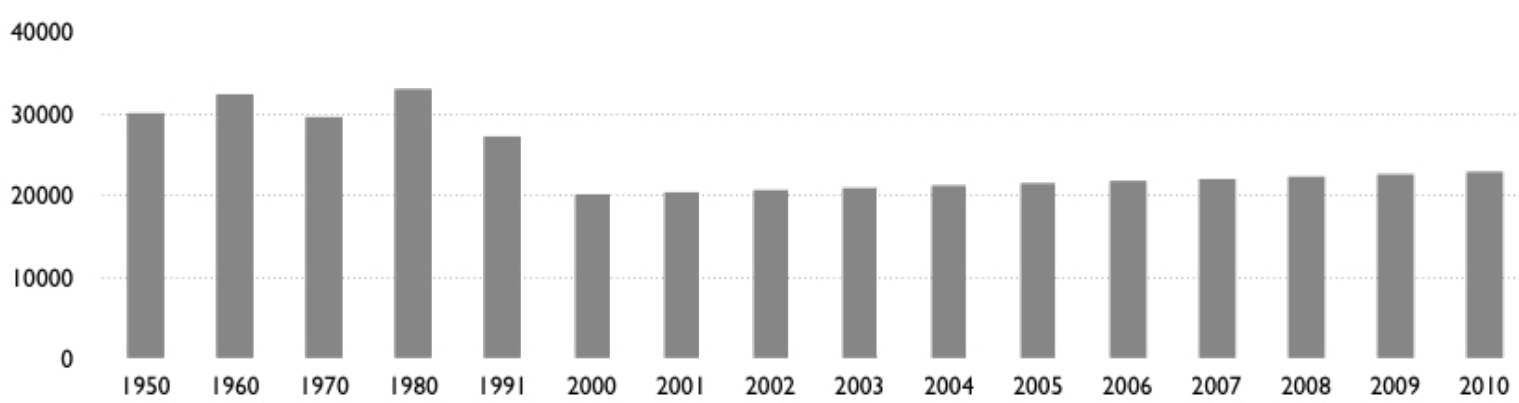

Gráfico 13 - População do bairro Sé 1950-2010

O distrito Sé apresenta uma flutuação similar à do Bom Retiro; cada década apresenta uma dinâmica distinta; em 1960 e em 1980 apresentam-se os níveis mais altos de população, enquanto nos anos 1950, 1970, 1990, mais baixos em relação àqueles, e em 2000, o mais baixo de todos. Na Sé a partir do ano 2000, passa a haver um aumento constante, mas nunca se alcança uma população similar à das décadas de 1950 ou 1960. 


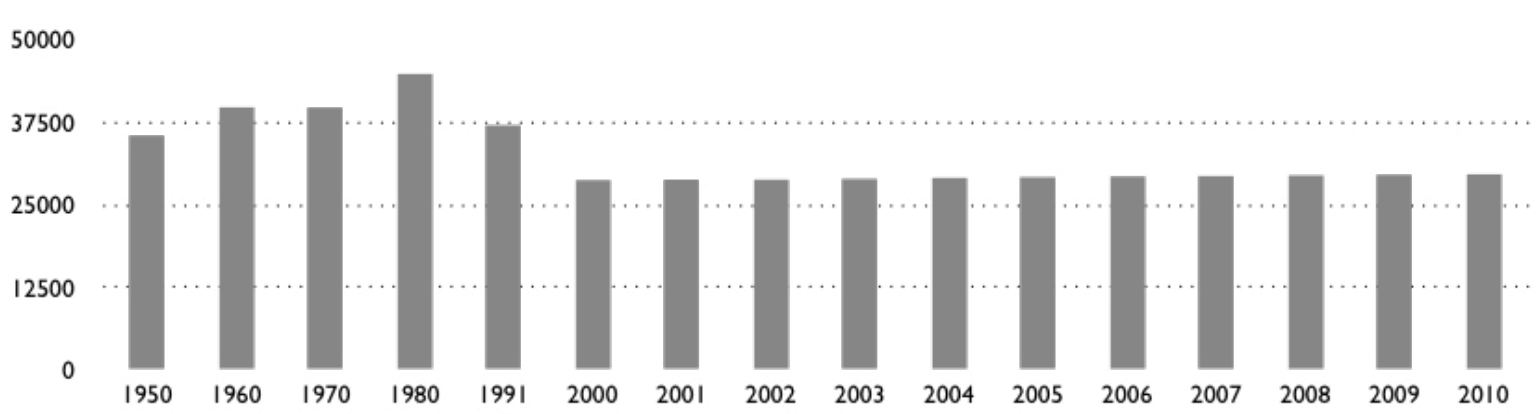

Gráfico 14- População do bairro Cambuci 1950-2010

O Cambuci apresenta um crescimento irregular entre as décadas de 1950 e de 1980; apresenta-se um declive drástico a partir da década 1980 até 2000, o decrescimento mais significativo e constante no distrito. A partir do ano 2000, a população se estabiliza na área, o que indica que os habitantes permanecem no setor, mas que não existem muitos residentes novos. $\mathrm{O}$ esvaziamento de moradores é claro. Observou-se que o período de crescimento da população de rua coincide com o período de esvaziamento do centro histórico (1980-2000), essa fuga de residentes constituiu uma tendência em todos os bairros nesse período.

\subsection{MORADORES DE RUA NO CENTRO DE SÃO PAULO NO 2002-2010}

Apresentaram-se os dados dos censos anteriores ao período pesquisado a fim de estabelecer o marco teórico no qual será baseada a análise do deslocamento dos moradores de rua da cidade de São Paulo. Os dados do último censo (2011) foram deixados para a análise a ser desenvolvida neste capítulo. A presente pesquisa estuda o período entre 2002 e 2010 para estabelecer o marco da análise dos bairros no centro da cidade e, a fim de entender as dinâmicas de deslocamento dos moradores de rua, 
utilizam-se os três censos desenvolvidos pela Prefeitura nesse período: 2000, 2009 e 2011. Cabe assinalar que, no último censo, esses são os três censos utilizados para comparar os dados da década; por razões que se desconhecem, a Prefeitura deixa de lado o censo de 2003. A presente pesquisa baseia sua análise nesses três anos (2000, 2009 e 2011), pois no censo de 2003 não se encontra a informação por bairro, dele só se obtêm dados globais da população de rua.

A partir desses censos (2000, 2009 e 2011), estabelecem-se dois períodos menores para a análise da informação: o primeiro, um período de nove anos (2000-2009), no qual a população de rua cresce 56\%; o segundo, um período de dois anos (2009-2011), no qual o povo de rua cresce 6\%. Esses períodos menores constituem pontos de referência dentro do período pesquisado com os quais se projetam tendências da população de rua na cidade de São Paulo.

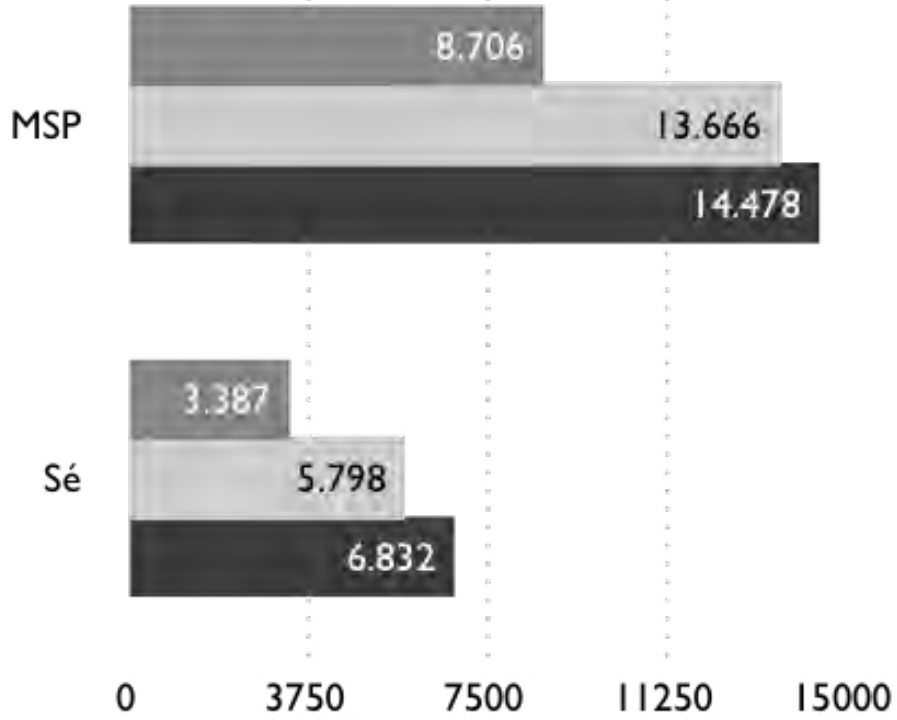

Gráfico 15 - Moradores de rua na cidade de São Paulo e na Subprefeitura Sé 
Considera-se que os dados do último censo devem ser analisados mais a fundo para responder às perguntas relacionadas com os deslocamentos no centro da cidade, pois oferecem diferentes perspectivas que apoiam a compreensão do fenômeno de rua, especificamente desses deslocamentos curtos. O último censo é de grande importância, pois completa o panorama do fenômeno de rua na última década. Entender o que acontece nesse decênio é crucial, já que nele desenvolvem-se ações de assistência social e renovação no centro da cidade. Nos três censos estudados, os pesquisadores dividem a população de rua em duas categorias: não acolhidos e acolhidos. Aqueles que moram na rua, que para fins da análise chamaremos de "não acolhidos", segundo o censo são pessoas que não têm moradia e que pernoitam nas ruas, praças, calçadas, marquises, jardins, embaixo de viadutos, mocós, terrenos baldios e áreas externas de imóveis. Diferentemente deles, os "acolhidos" são definidos como aqueles que, como bem o termo explica, são acolhidos pelo sistema de assistência social da Prefeitura, o que quer dizer que são pessoas que, também sem moradia, pernoitam em albergues ou abrigos. Nota-se que os censos fazem outras distinções da população de rua, de gênero, escolaridade e grupo etário, mas para fins da análise do deslocamento dos moradores de rua e de sua relação com o equipamento da Prefeitura da cidade nessa área, centraremos a análise apenas nas duas categorias apontadas.

Os pesquisadores assinalam que, para os indivíduos que entraram na vida de rua, existem duas opções, a rua ou o albergue, apresentando-se como faces da mesma moeda. Esses dois espaços são os lugares habitualmente utilizados pela população em situação de rua desde que se perdeu a última moradia. 
Portanto, utilizar para a análise essas categorias (acolhido e não acolhido) faz sentido absoluto, pois se relacionam tanto com a condição inerente ao fenômeno pesquisado ("morar na rua") quanto com as perguntas anteriormente apresentadas na presente pesquisa, em que se procura a relação entre a assistência social e o fenômeno da rua.

O fato de que a Prefeitura faça uma clara distinção entre os indivíduos em situação de rua acolhidos e não acolhidos, denota o senso de autoavaliação por parte desse órgão e evidencia o desejo de conhecer a quantidade de moradores de rua que fazem uso do equipamento assistencial. Constitui uma categoria com que a própria entidade avalia o sistema de assistência social que oferece à cidade; essa categorização relacionase com o número de pessoas em situação de rua que são assistidas pelo sistema e, em termos da vida de rua, com as que escolhem não ser assistidas. Outra possível motivação do poder local é a procura de dados quantitativos que orientem a tomada de decisões. Os não acolhidos podem considerar-se o público-alvo da Prefeitura, pois precisam da assistência, portanto devem-se dirigir novas ações ou estratégias que ampliem a abrangência da assistência, o que pode implicar mudanças qualitativas na assistência oferecida. Por outro lado, o fato de que os censos ofereçam uma relação entre a população de rua e o território que ocupam, permite que a Prefeitura monitore a relação quantitativa, pois é outra forma de avaliar se o orçamento investido é gasto de maneira efetiva e eficiente nos bairros que contam com o equipamento. Outro dos motivos pelo qual se escolheu focar a análise primordialmente nessas duas categorias (acolhido e não acolhido) foi a abordagem dos indivíduos em situação de rua neste estudo. Na presente pesquisa, considera-se que as pessoas em situação de rua moram no centro da cidade; embora suas condições não sejam formais e fixas, 
eles ocupam espaços públicos da cidade e neles desenvolvem sua vida cotidiana; mesmo que façam uso de algum equipamento assistencial para apoiar-se, eles primordialmente ocupam o espaço público para viver. Conhecer a quantidade de indivíduos em situação de rua acolhidos e não acolhidos permite identificar os territórios da cidade aos que eles se deslocam a fim de obter assistência.

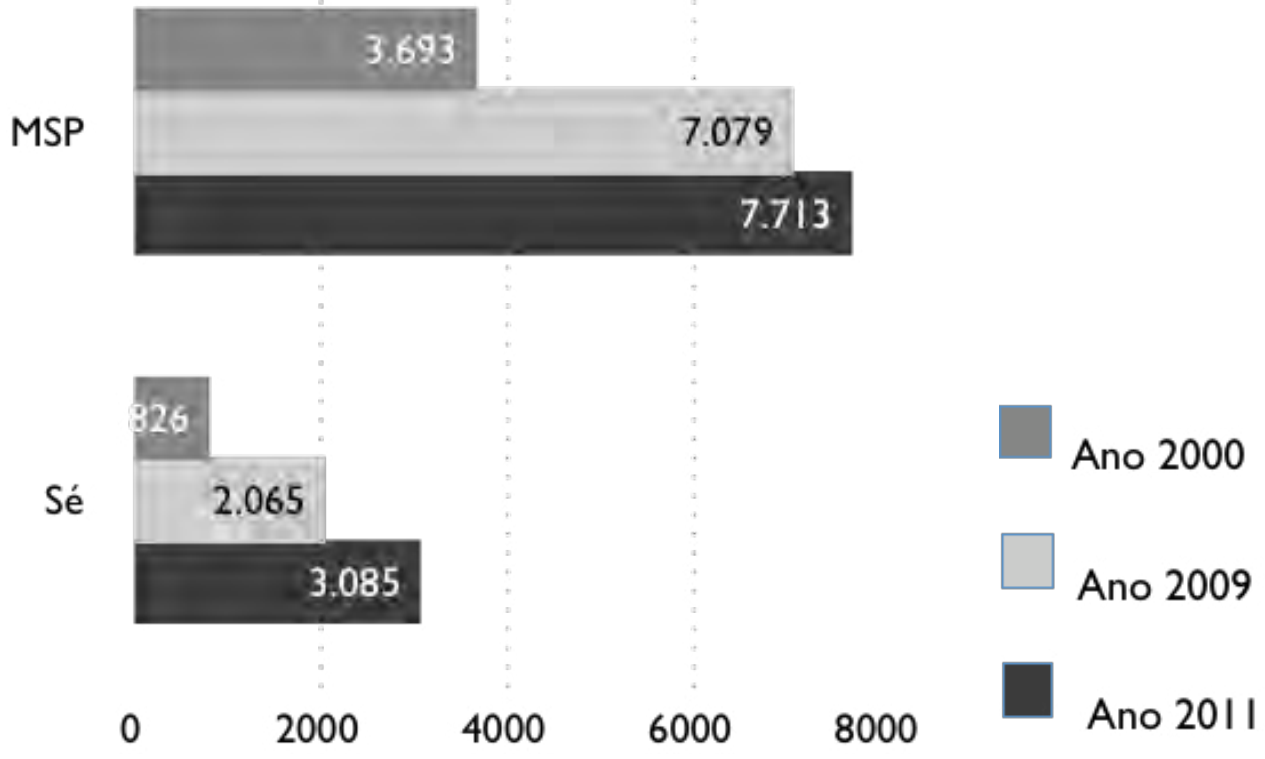

\section{Gráfico 16 - Moradores de rua acolhidos na cidade de São Paulo e na Subprefeitura Sé}

A população dos moradores de rua acolhidos nos centros assistenciais da Prefeitura apresenta um crescimento consistente com a tendência global do progressivo aumento da população de rua. Essa tendência na cidade se reproduz na área central ou Subprefeitura Sé, com distintivas variações nos dois períodos menores. O crescimento apresenta-se intensamente no período de 2000 a 2009, no qual a população acolhida quase se duplica, pois cresceu 92\%, e parece frear no período entre 2009 e 2011, quando cresceu só 9\%. Ao analisarem-se os dados, observa-se que cresceu tanto o número de moradores de rua que procuram assistência quanto a própria assistência; 
no caso desta, observa-se que aumentou o número de serviços e espaços que acolhem os moradores na cidade no período pesquisado. As pessoas em situação de rua foram recebidas em Centros de Acolhida e Centros de Acolhida Especiais conveniados com a Secretaria Municipal de Assistência e Desenvolvimento Social (SMADS) - nova denominação para os serviços conhecidos anteriormente como Albergues e Abrigos especiais. Foram também incluídas na contagem as vagas existentes nas Repúblicas e Hotéis Sociais (conveniados) e nos Abrigos não conveniados com a SMADS.

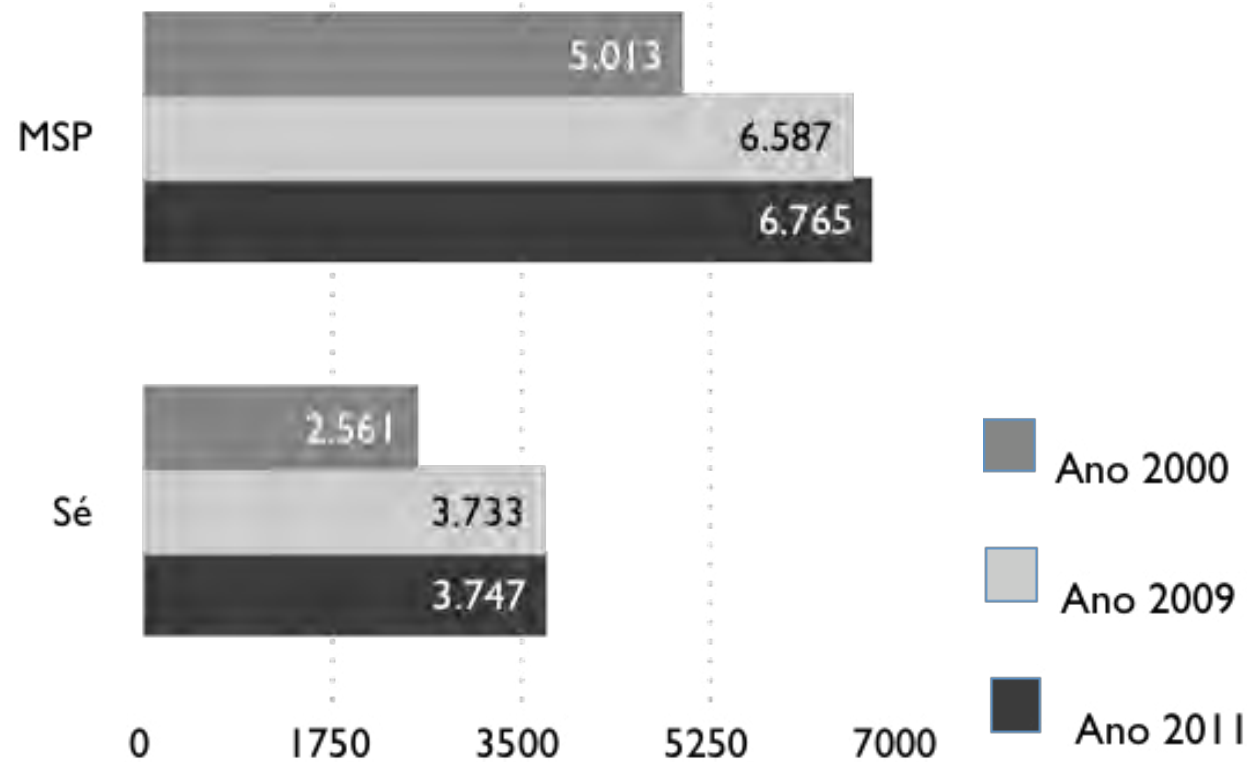

\section{Gráfico 17 - Moradores de rua não acolhidos na cidade de São Paulo e na Subprefeitura Sé}

Ao analisar a população que mora na rua, os não acolhidos, percebe-se uma diminuição no crescimento dessa população, nas escalas municipal e central nos últimos anos. Entre 2000 e 2009, houve um crescimento de 31\%; considerando-se que constitui um período de 9 anos e distribuindo-se o crescimento equitativamente, isso equivale a um aumento de 3,44\% por ano. Em contraste, entre 2009 e 2011, a população cresceu só 3\% na cidade, o que equivaleria a 1,5\% por ano. 
O panorama na área central da cidade é similar, pois mesmo que o crescimento atenuado de $46 \%$ no período de 2000 a 2009 indique um aumento na população do centro, no período entre 2009 e 2011 esse crescimento se reduz; segundo o censo, a população de rua não acolhida aumenta só 14 indivíduos nesse período, o que não constitui nem $1 \%$ da população.

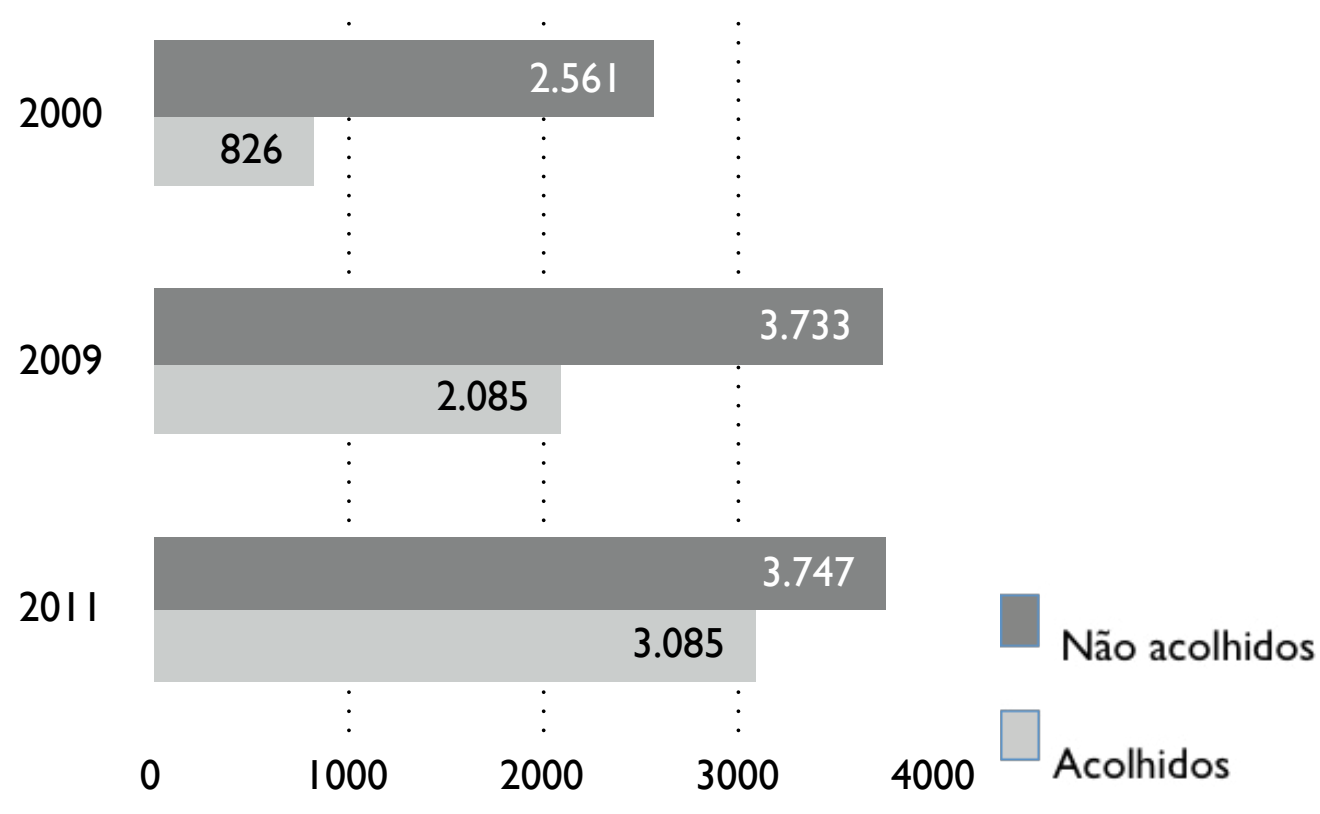

Gráfico 18 - Moradores de rua não acolhidos e acolhidos no Centro $2000 / 2009$ / 2011

A fim de completar a análise dos deslocamentos dos moradores de rua no centro da cidade, e também para estabelecerem-se as conclusões da pesquisa, incluiu-se o resto da informação relacionada com os censos. Os resultados dos censos de 1991 a 2011 evidenciam o crescimento do fenômeno de rua, mesmo assim decidiu-se incorporar os dados das duas categorias, acolhidos e não acolhidos, a fim de entender em um contexto mais amplo o desenvolvimento dos dois grupos de pessoas em situação de rua. 
Não acolhidos

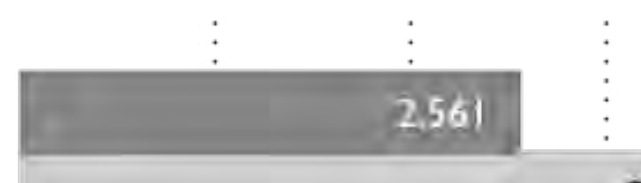

\section{.}

\section{E}

Acolhidos

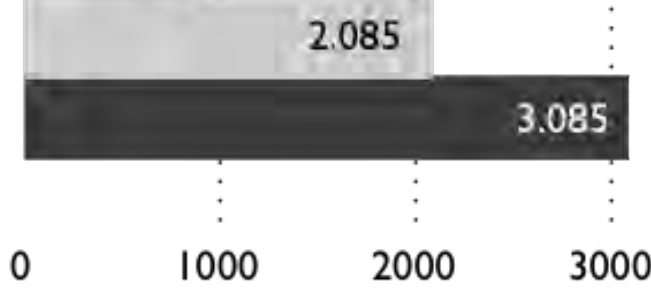

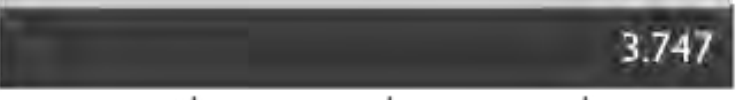

\section{6}

3.733

\subsection{7}

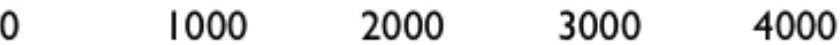

Ano 2000

Ano 2009

Ano 2011

\section{Gráfico 19 - Moradores de rua não acolhidos e acolhidos no Centro $2000 / 2009 / 2011$}

Cabe assinalar que nem todos os censos possuem essa categorização, pois os de 1991, 1993 e 1997 só se concentraram na contagem da totalidade da população. Outro ponto importante da análise é o fato de que nem todos os censos foram desenvolvidos na mesma época do ano, sendo as exceções os dois últimos censos que foram realizados em novembro.

\begin{tabular}{|c|l|l|l|l|l|l|l|l|l|l|}
\hline Ano & I99I & 1993 & 1994 & 1996 & 1997 & 1998 & 2000 & 2003 & 2009 & 201 I \\
\hline Mes do conteo & Maio & Outubro & Agosto & Setembro & Fevereiro & Dezembro & Fevereiro & Outubro & Novembro & Novembro \\
\hline Instituição & SEBES & & FABES & FABES & & FABES & FIPE & FIPE & FIPE & FIPE \\
\hline Acolhidos & & & 1749 & 1913 & & 3416 & 3693 & 6186 & 7.079 & 7.713 \\
\hline Não acolhidos & & & 2800 & 3421 & & 3037 & 5013 & 4214 & 6.587 & 6765 \\
\hline Total & 3392 & 4500 & 4549 & 5334 & 5400 & 6453 & 8706 & 10400 & 13666 & I4478 \\
\hline
\end{tabular}

Tabela 4 - Censos de moradores de rua na cidade de São Paulo 


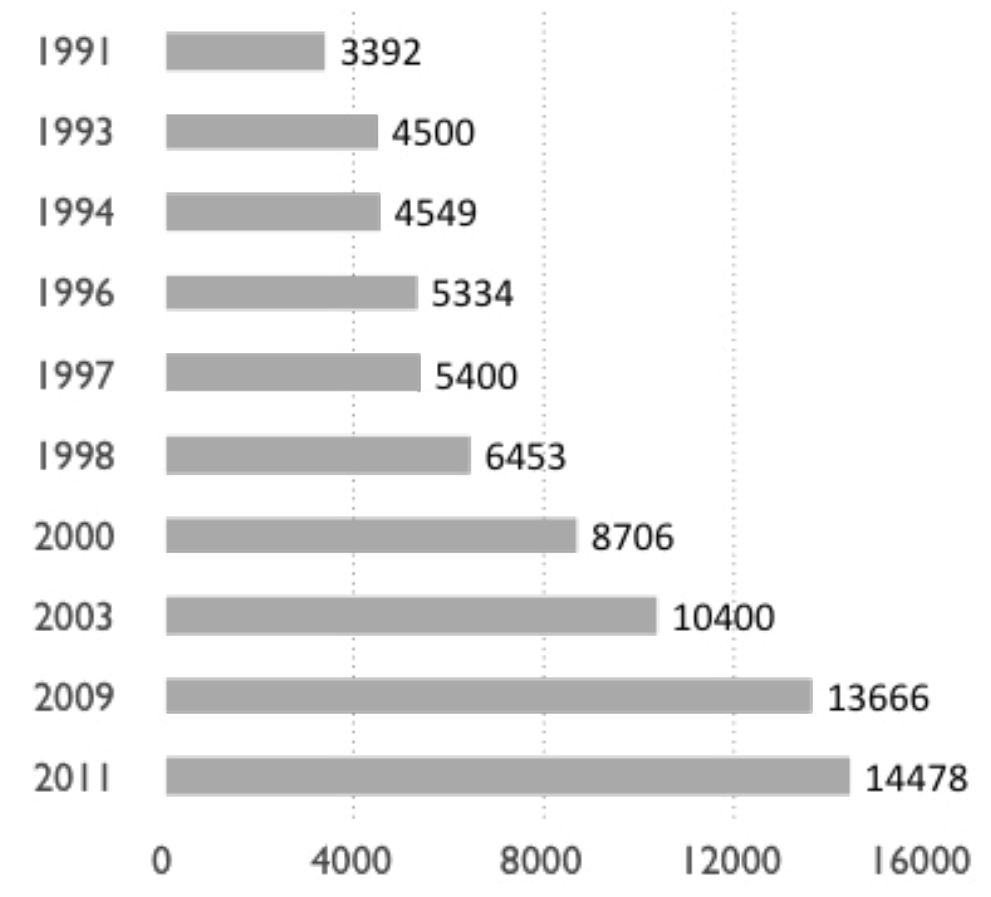

Modadores de rua (acolhidos/não acolhidos

Gráfico 20 - Total de moradores de rua no Centro 1991-2011

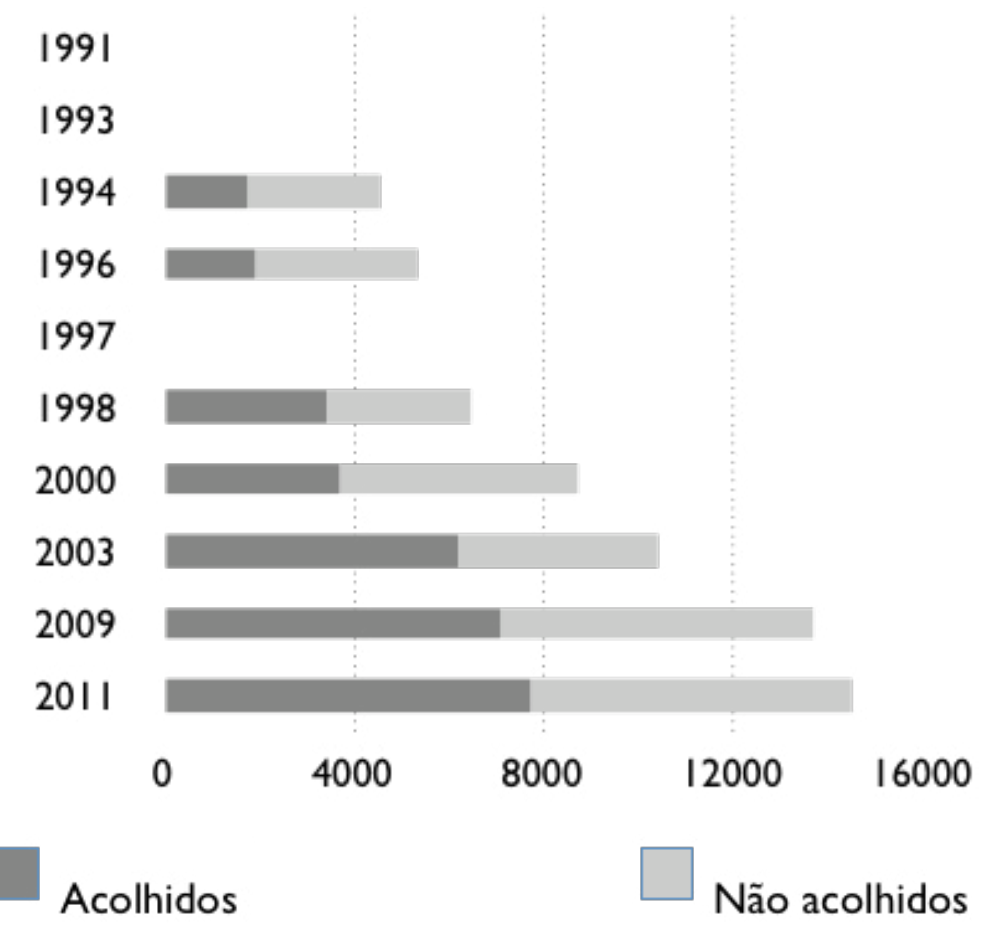

Gráfico 21 - Moradores de rua não acolhidos e acolhidos no Centro 1991-2011 
Os dados mostram variações na população de rua não acolhida; isso quer dizer que, mesmo que esse número venha aumentando desde 1994, alguns anos apresentam quedas no número de pessoas que moram nas ruas da cidade. Em contraste, ao comparar os dados dos anos que apresentam quantidades baixas de moradores de rua não acolhidos (1993-3037 / 1998-4214), observa-se um aumento da população acolhida (1993-3416 / 1998-6186), isso indica que existem períodos de tempo em que a população de rua procura acolhimento e as ruas se "esvaziam" de moradores. Nesses períodos de esvaziamento, os moradores de rua se deslocam à procura de centros de acolhida nos quais recebem o apoio do sistema de assistência social, seja um deslocamento longo de uma área da cidade a outra, seja um deslocamento curto dentro do mesmo setor.

Os motivos desses esvaziamentos podem variar, como assinalou-se anteriormente, por isso, a fim de esclarecer as circunstâncias específicas dessas movimentações de pessoas em situação de rua, devem ser consultados outros estudos, específicos os dos anos 1998 e 2003. Procuraram-se, em relação a esses esvaziamentos, ações de renovação que pudessem ter causado algum tipo de expulsão por parte do poder local, mas não se encontrou nenhuma comprovação consistente disso. Os projetos de renovação em andamento podem ter influenciado a diminuição da população de moradores nas ruas, mas não se encontrou um indício claro disso. Diferentemente das variações da quantidade de pessoas não acolhidas, o crescimento constante da população acolhida assinala o claro papel da assistência social como polo atraente de moradores de rua ao centro da cidade. Os números indicam que a cada ano a quantidade de moradores de rua que procura apoio aumenta, seja por uns dias 
ou por períodos mais longos; ano a ano mais moradores de rua são acolhidos pelo equipamento municipal, essa quantidade cresceu até superar o número de não acolhidos na cidade. Isso indica que hoje existem mais moradores de rua nos centros de assistência social que nas ruas; sem dúvida, as mudanças implementadas pelo sistema de assistência social tanto ampliaram a abrangência dos serviços, quanto aumentaram o número de vagas oferecidas. Os números assinalam que a predominância dos moradores de rua acolhidos na cidade é uma tendência da última década, pois nas contagens a partir do ano 2003 fica claro o aumento do número de acolhidos pelo sistema assistencial da Prefeitura da cidade de São Paulo.

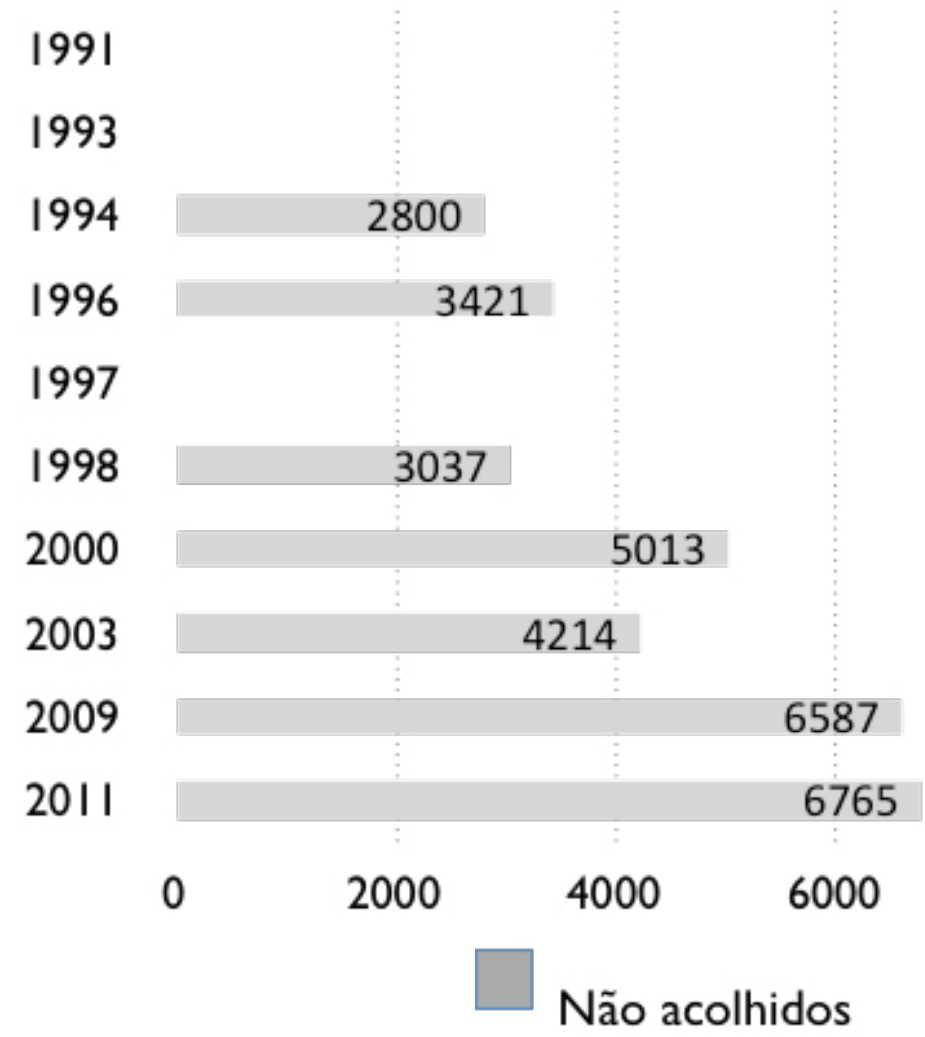

Gráfico 22 - Moradores de rua não acolhidos no Centro 1991-2011

Segundo o último censo, a percepção é que o problema do indivíduo em situação 
de rua que vive em centros de acolhida na cidade de São Paulo é mais de natureza psicossocial do que apenas econômico. As últimas pesquisas realizadas para essa contagem focaram a situação daqueles que frequentam esses centros, o que permitiu esclarecer o perfil do indivíduo em situação de rua que é acolhido pelo sistema. Foi assim que chegaram à conclusão de que o principal problema da população acolhida não pode ser considerado essencialmente econômico, pois boa parte trabalha, ganha quantias similares ou até mesmo superiores ao salário mínimo e tem um razoável nível de escolaridade prévio a sua inserção à vida de rua (FESPSP, 2009, p. 29).

1991

1993

1994

1996

1997

1998

2000

2003

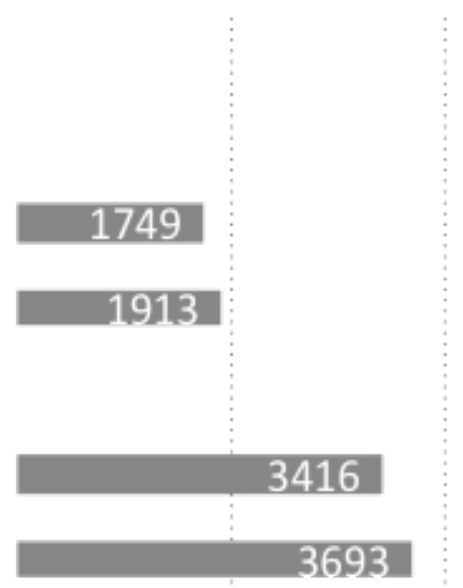

2009

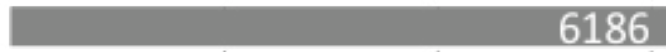

2011
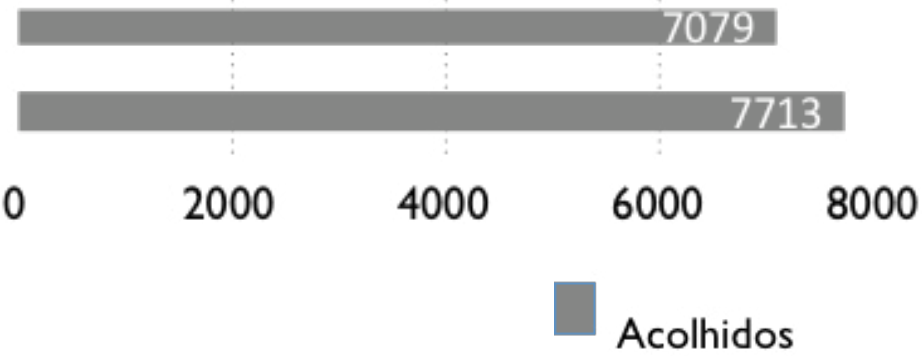

Gráfico 23-Moradores de rua não acolhidos e acolhidos no Centro 1991-2011

A comparação dos dados do total de moradores de rua acolhidos e não acolhidos deixam algo claro: a tendência do crescimento da população acolhida 
continuará nos próximos anos; diferentemente da população não acolhida, os dados de 1994 até 2011 apontam para o crescimento gradativo e constante daqueles que procuram o sistema assistencial da cidade. Nesse mesmo período, os moradores de rua não acolhidos apresentam um comportamento irregular; as constantes variações não permitem predizer tendências, seja o crescimento ou a diminuição do número de pessoas em situação de rua que se recusam a procurar acolhimento no sistemas.

\subsubsection{MORADORES DE RUA ACOLHIDOS E NÃO ACOLHIDOS NOS BAIRROS DO CENTRO}

É de suma importância olhar as contagens da área central, já que cada bairro na Subprefeitura Sé apresenta dinâmicas particulares em relação aos moradores de rua acolhidos e não acolhidos. Ao olhar a informação das contagens dos bairros, descobrimos os espaços do centro da cidade onde se concentram moradores de rua acolhidos e não acolhidos; isso permite determinar a influência da assistência social como polo atraente dos moradores de rua no centro.

À primeira vista é fácil observar, com os dados dos três censos, que a tendência global é o crescimento da população de rua tanto na cidade, quanto no centro; mas a análise do total da população de rua na Área Central oferece um panorama mais complexo. Os bairros parecem possuir poucos pontos em comum, aparentam ter uma dinâmica individual, e embora os dados dos censos de 2000 e 2009 assinalem que os bairros Sé e República apresentam a maior concentração de moradores de rua no centro, o último censo (2011) apresenta dados que evidenciam uma mudança nessa tendência. 


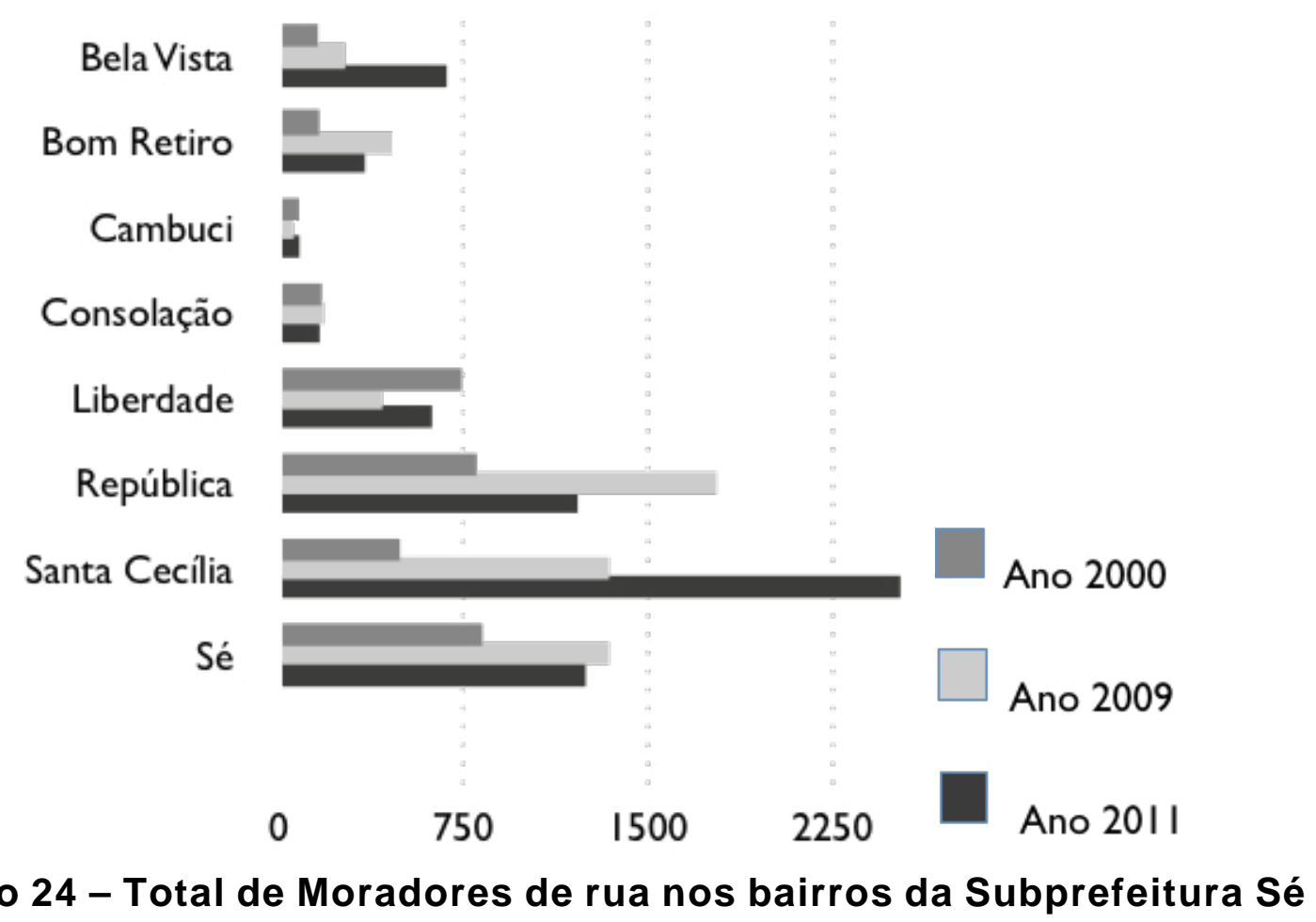

No censo de 2011, Santa Cecília se destaca como o bairro da área central que concentra a maior quantidade de população em situação de rua, o que constitui uma mudança drástica na dinâmica que existia nessa área. Tanto Sé quanto República perdem moradores de rua, segundo a última contagem. Essa mudança leva a questionarse a distribuição dos moradores de rua no território, pois a dinâmica interna na área central mudou, seja pelo aumento nas vagas do equipamento de assistência para a população de rua ou pela expulsão dessa população por parte de terceiros. Se o número de moradores de rua na área central aumenta, e os bairros que até então concentravam o maior número de indivíduos em situação de rua apresentam "baixas", para onde migram os moradores de rua que deixam a Sé e a República? Pode afirmarse que são esses dois fatores (assistência e renovação) que os impulsionam a migrar de bairro, mesmo que permaneçam dentro do perímetro da área central? A procura de respostas para essas perguntas levaram a uma análise da informação dos três 
censos a partir de duas escalas: a global, que se refere ao centro da cidade, e a de cada um dos bairros.

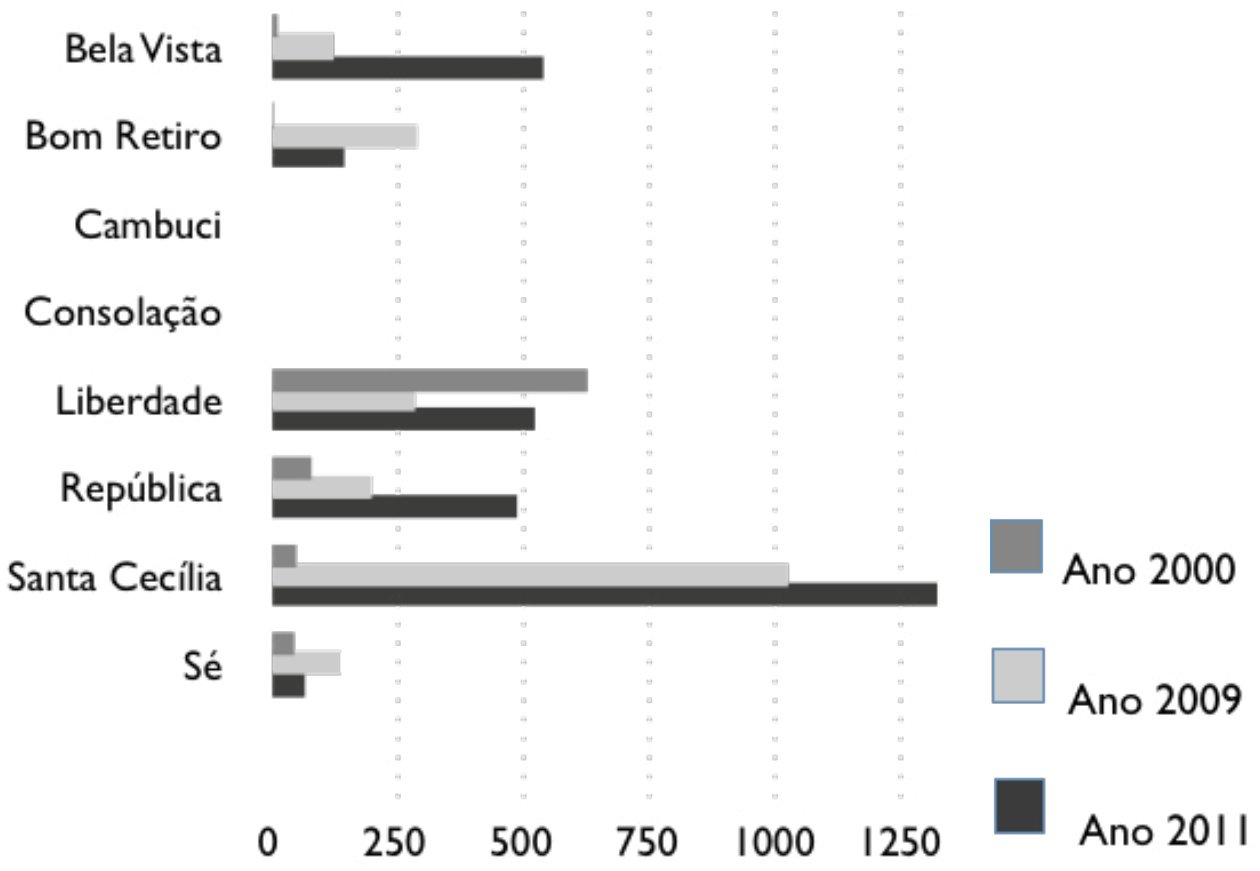

Gráfico 25 - Moradores de rua acolhidos na Subprefeitura Se

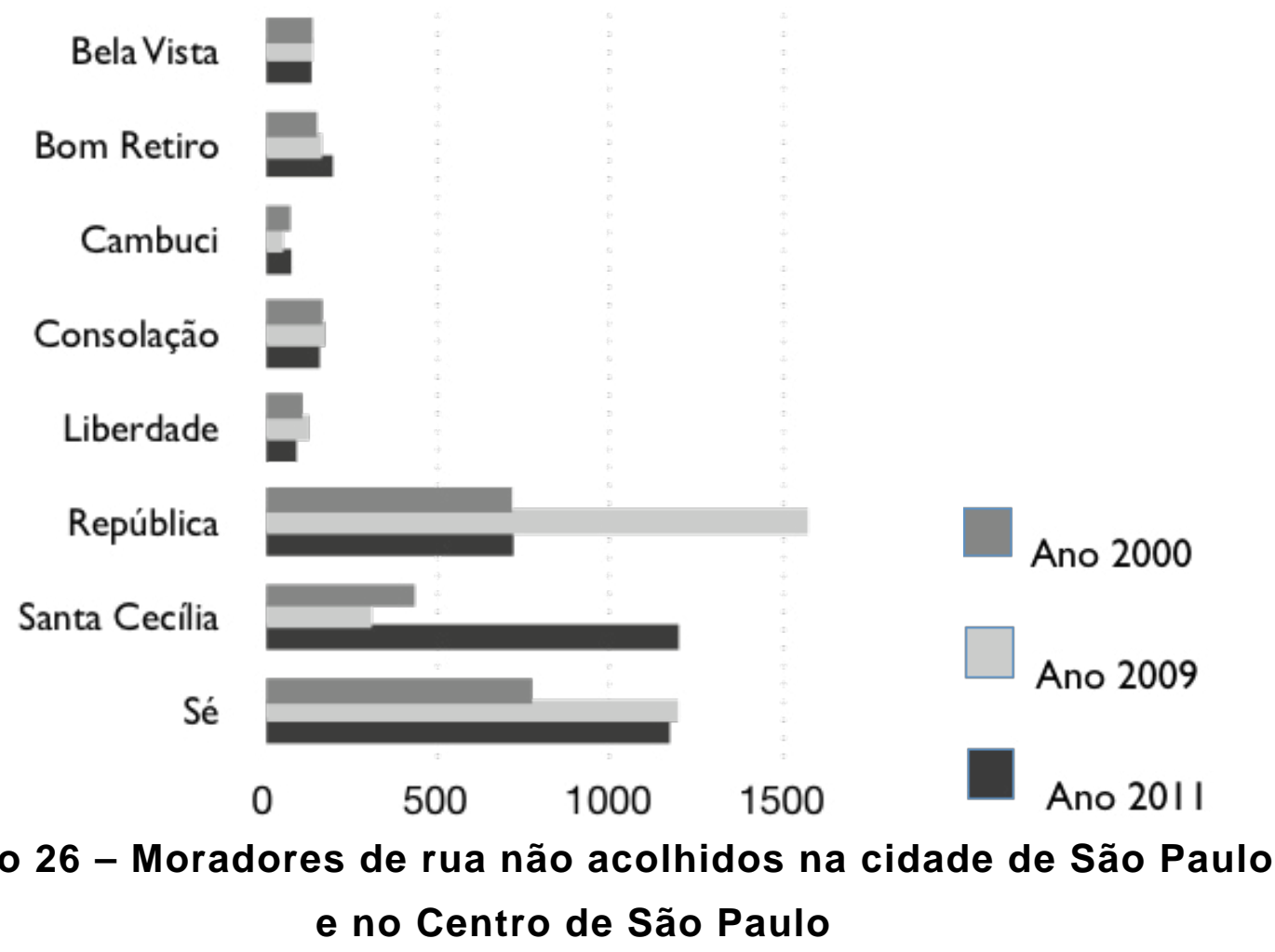


Alguns dos bairros da área central não possuem equipamento de assistência especializado em pessoas em situação de rua, tal é o caso de Consolação e Cambuci, e nem por isso deixam de ter população não acolhida, pois, como já se assinalou, esses bairros fazem parte da área da cidade que concentra a população pesquisada. Embora o censo de 2009 assinale que nem todos os moradores de rua procurem acolhimento em centros do sistema assistencial, também afirma que a tendência daqueles que chegam à rua é procurar albergue, pois poucos contaram com o apoio de parentes e amigos ou tiveram condição de ir para uma pensão ou cômodo, antes de chegarem à situação de rua.

Mesmo que dois dos bairros apresentem falta de equipamento assistencial relacionado com as pessoas em situação de rua, na mesma área da cidade um outro bairro parece atrair mais moradores de rua que procuram acolhimento. O bairro de Santa Cecília apresenta uma crescente população de acolhidos; no período entre 2000 e 2009 as pessoas em situação de rua parecem preferir acolher-se nesse bairro, fato que continua no período seguinte (2009-2012).

Essa tendência pode relacionar-se com o fato de que o bairro está próximo da Cracolândia, razão pela qual muitas das "novas" vagas para moradores de rua se localizam nesse perímetro. Outra das razões pela qual é importante a análise por bairro é a variação nos dados, porque nem todos apresentam a mesma dinâmica de uso do equipamento. Os números indicam que, mesmo que a tendência da área central seja o aumento da população de rua acolhida nos equipamentos, cada bairro apresenta dinâmicas distintas. 
À primeira vista, percebe-se que os bairros que oferecem esses espaços de assistência não têm uma presença significativa de moradores de rua não acolhidos, é como se o propósito de oferecer vagas nesses bairros fosse esvaziar os outros bairros que possuem uma forte presença de moradores nas ruas.

Em relação à variação do número de vagas ou espaços para acolher moradores de rua no equipamento assistencial, apresentam-se três dinâmicas nos oito bairros que constituem a Subprefeitura Sé. A primeira dinâmica é o aumento da população acolhida, portanto congruente com a tendência da área central; observa-se que o número de vagas para as pessoas em situação de rua cresce nos dois períodos (20002009 e 2009-2011) nos bairros de Bela Vista, República e Santa Cecília.

A segunda tendência constitui uma variação atípica nos bairros da área central: há um crescimento progressivo durante 9 anos e um dramático decrescimento da população acolhida em dois anos, o que quer dizer que nesses bairros menos pessoas em situação de rua procuram acolhimento, seja porque nos centros de assistência se reduzem as vagas oferecidas ou porque menos moradores de rua procuram acolhida nesses espaços.

Os bairros que possuem essa dinâmica de decrescimento são Bom Retiro e Sé. A última tendência apresenta-se em um bairro só, é outra variação atípica da população acolhida, que se acha na Liberdade, o que quer dizer que, segundo os censos, os centros assistenciais que acolhiam moradores de rua apresentaram uma redução na população de rua atendida e um posterior aumento. 


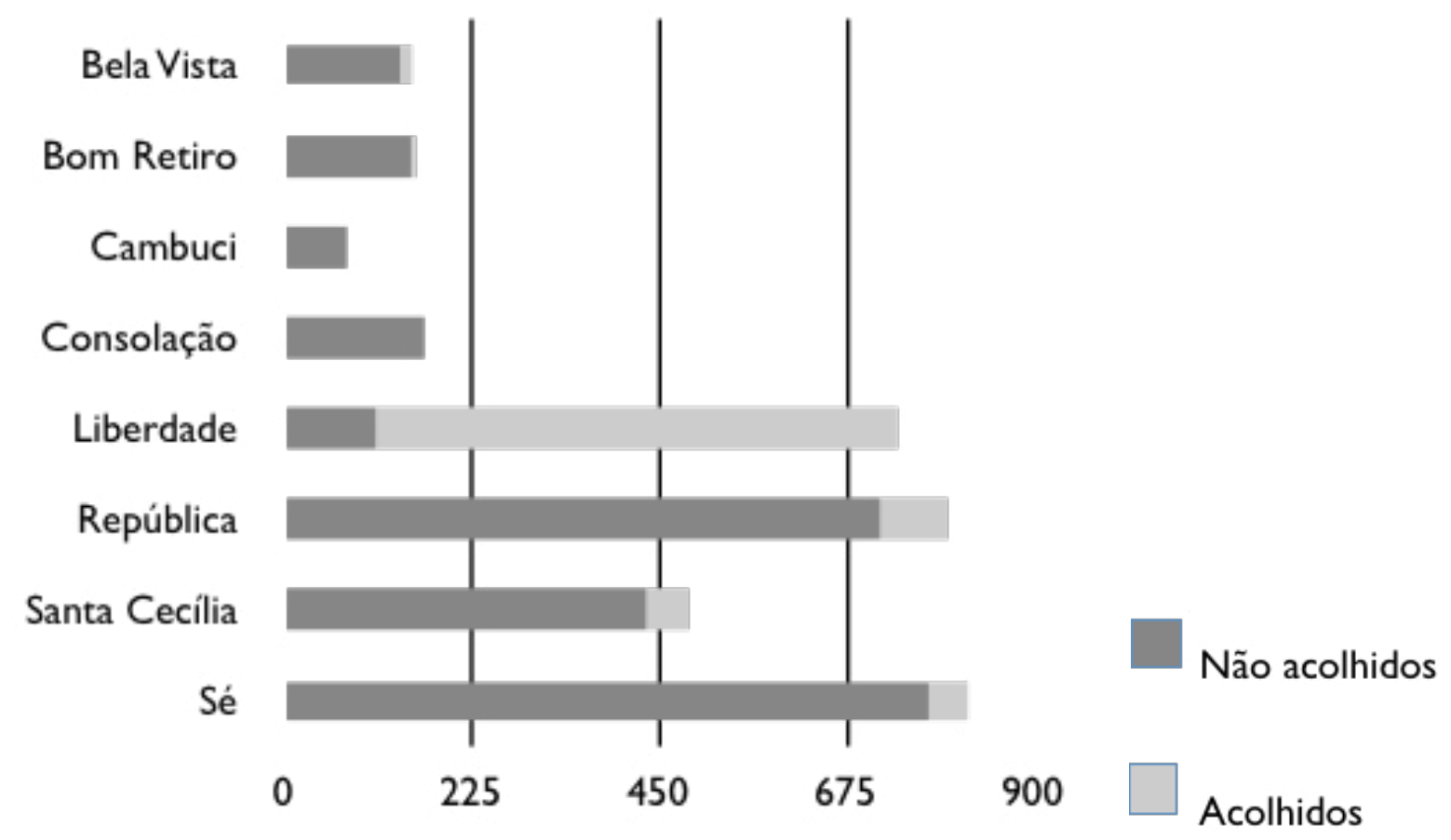

Gráfico 27 - Moradores de rua não acolhidos e acolhidos no Centro de São Paulo 2000

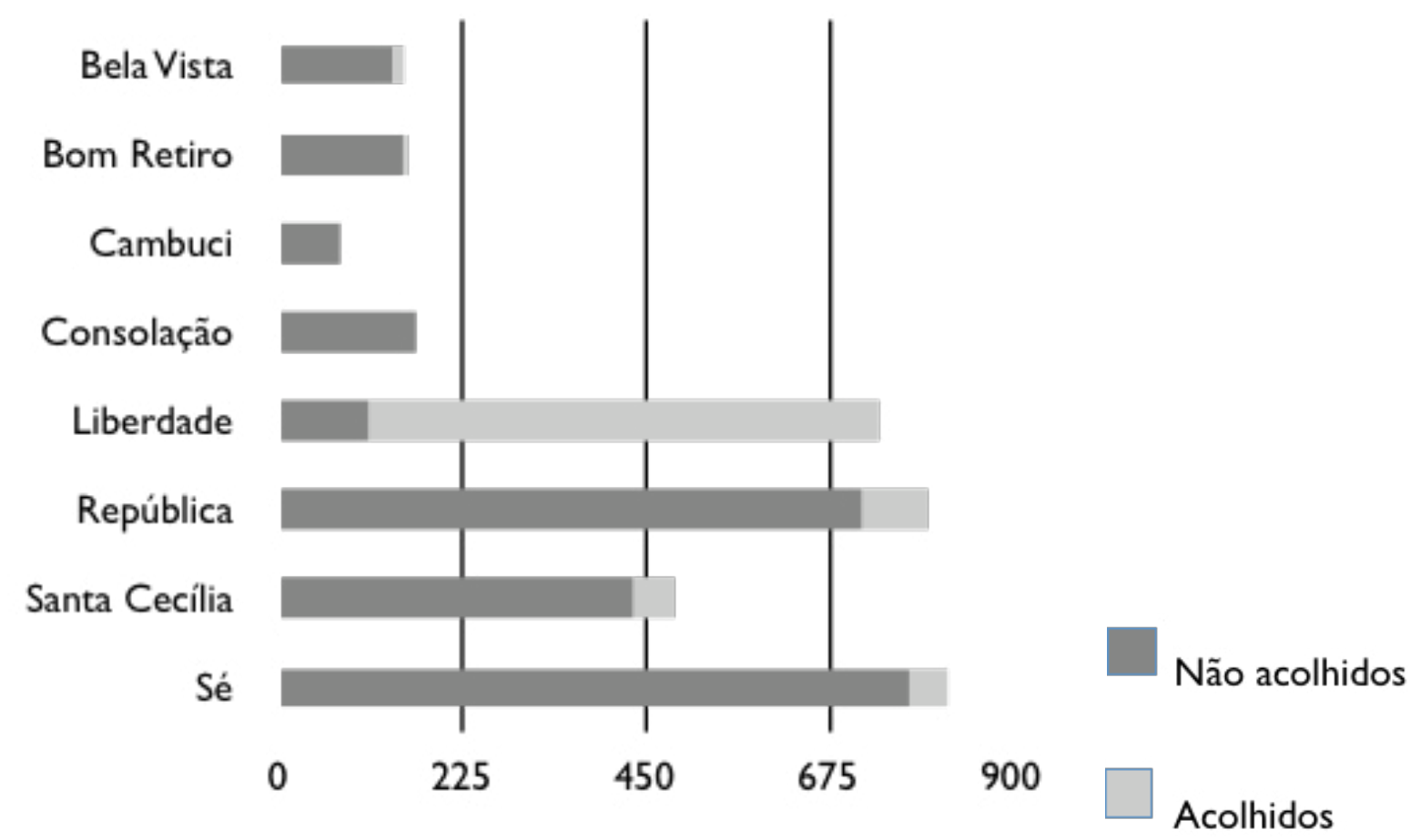

Gráfico 28 - Moradores de rua não acolhidos e acolhidos no Centro de São Paulo 2009 


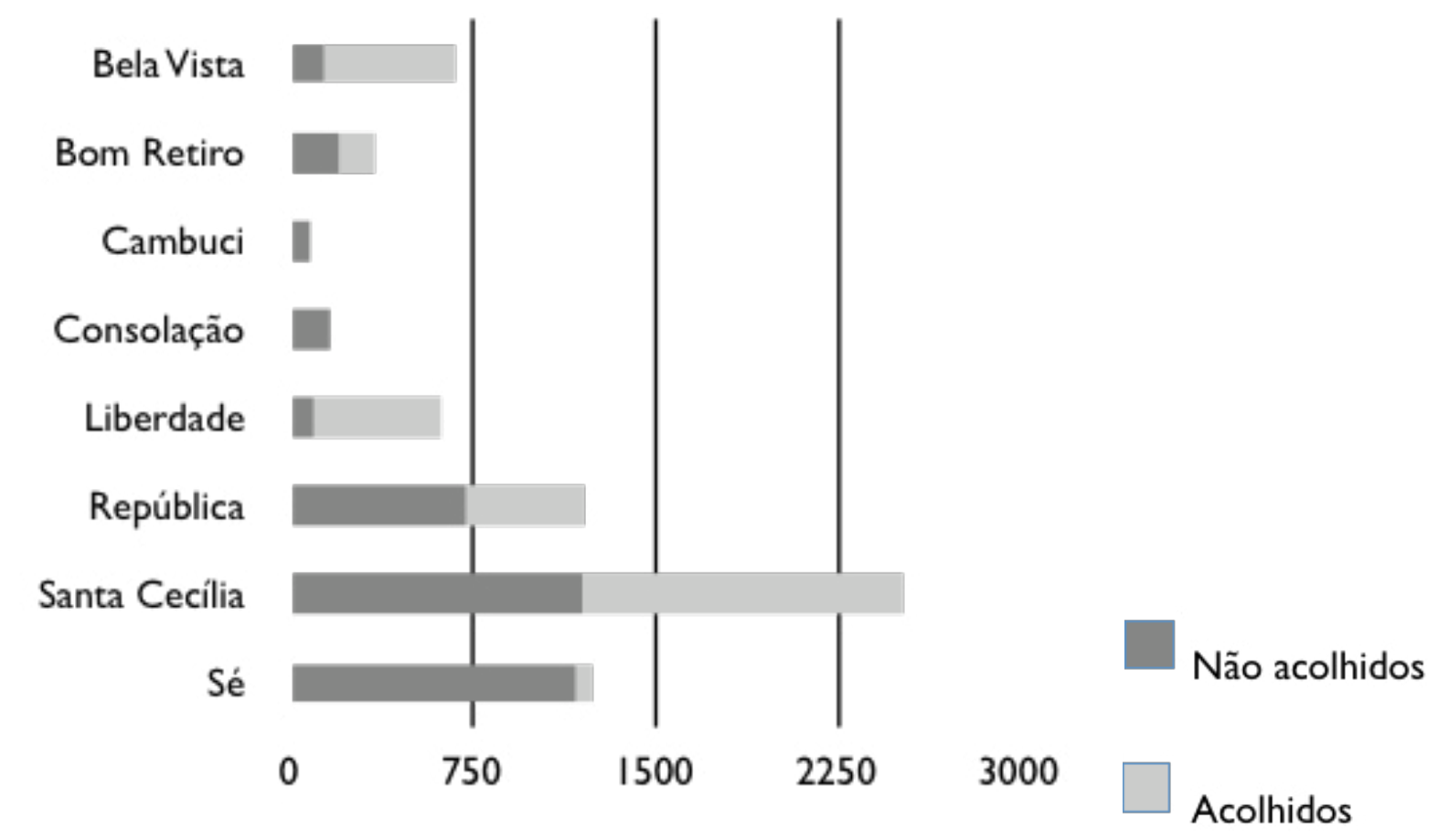

Gráfico 29 - Moradores de rua não acolhidos e acolhidos no Centro de São Paulo 2011

As estatísticas específicas dos bairros apresentam um panorama mais complexo; em relação aos não acolhidos, cinco dos oito bairros que constituem a Subprefeitura Sé apresentam números baixos de moradores de rua em contraste com os três bairros que apresentam a maior quantidade de moradores tanto na área central, quanto na cidade segundo o censo 2011. Os bairros de Bela Vista, Bom Retiro, Cambuci, Consolação e Liberdade possuem poucas variações no crescimento da população de não acolhidos; pode afirmar-se que esses bairros têm uma população estável e, como se afirmou, já reduzida em relação aos outros três bairros. Por outro lado, os bairros que concentram uma grande quantidade de moradores de rua, tanto na área, quanto na cidade, são os que apresentam maiores variações em relação aos não acolhidos, os bairros República, Santa Cecília e Sé. Outra forma de abordar a análise do número de moradores de rua nos bairros é a revisão paralela dos dados das três contagens, 
pois, ao olhar o total de moradores de rua em cada bairro, incluindo acolhidos e não acolhidos, identifica-se o crescimento gradativo da população acolhida no centro da cidade. De maneira geral, observa-se a tendência do aumento de vagas de assistência social relacionadas ao atendimento de moradores de rua na cidade de São Paulo. O censo de 2011 registrou que "a área central passa a concentrar a maioria das pessoas acolhidas, alcançando 5.694 casos contra 2.019 casos encontrados em outras áreas". Gradativamente os indivíduos em situação de rua fazem mais uso dos equipamentos de assistência social no centro da cidade; o fato de que no último censo se assinale uma grande movimentação das pessoas recenseadas nos centros de acolhida indica uma frequência no uso dos equipamentos nessa área. Se a tendência continuar, o centro da cidade terá mais moradores de rua nos centros de acolhida que nos espaços públicos (FESPSP, 2012, p. 23).

A fim de entender o desenvolvimento dessa tendência no período pesquisado, analisase a população de rua em cada bairro. O número de vagas oferecido pelo sistema de assistência social aos moradores de rua se distribui no equipamento no centro da cidade em seis bairros; os bairros Cambuci e Consolação não participam dessa dinâmica por não terem equipamentos de assistência especializados. Ao comparar os gráficos da população de rua dos bairros, observa-se a estabilidade em relação ao número de indivíduos não acolhidos. Um fato curioso do exame dos dois bairros é que existem mais moradores de rua no bairro Consolação, um dos mais nobres do centro, e uma quantidade mínima no Cambuci, mesmo que nesse último o comércio pudesse ser um fator atraente para desenvolver alguma estratégia de sobrevivência. O fato de que estes sejam os bairros com os valores mais baixos de moradores de 
rua induz a concluir que a ausência de equipamento assistencial tem a ver com a ausência de moradores de rua. O panorama se complica ao inverter a afirmação anterior, pois talvez, se existissem mais moradores de rua, a Prefeitura procuraria atendê-los, e a consequência disso seria a existência de equipamento assistencial nesses bairros.

Cambuci 2000

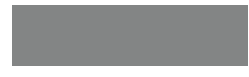

Cambuci 2009

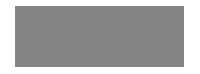

Cambuci 2011

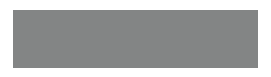

Não acolhidos

0 100 200

Acolhidos

Gráfico 30 - Moradores de rua não acolhidos e acolhidos no Bairro Cambuci 2000 / 2009 / 2011

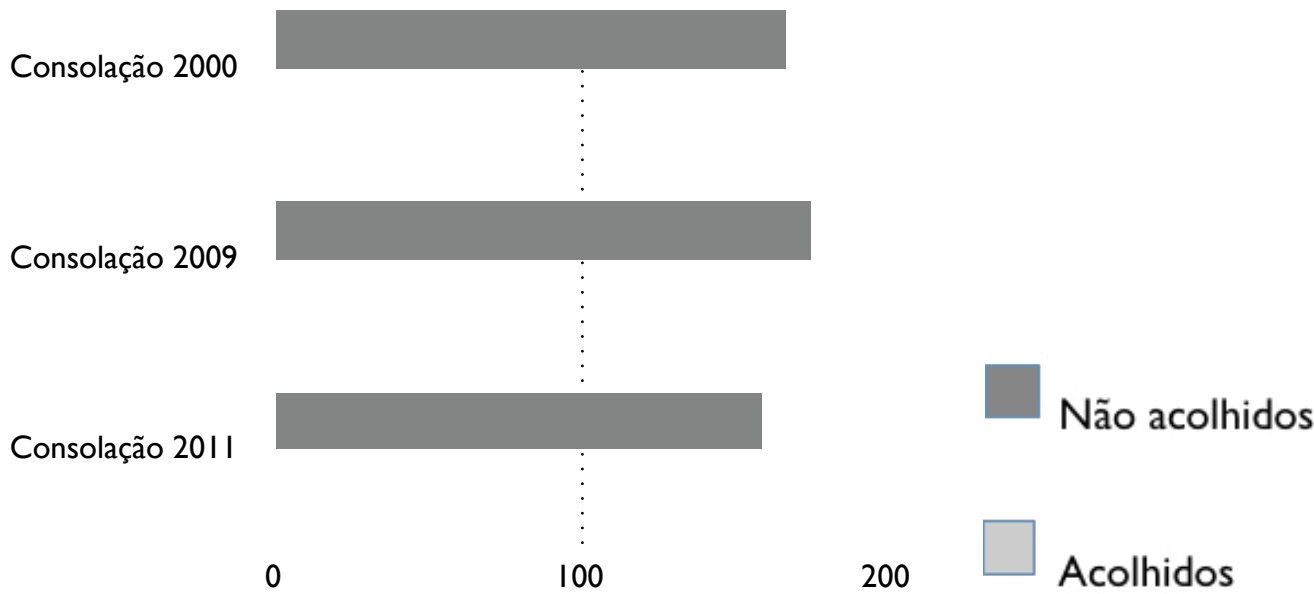

Gráfico 31 - Moradores de rua não acolhidos e acolhidos no Bairro Cambuci 2000 / 2009 / 2011 
Nos bairros República e Sé, apresenta-se a predominância dos não acolhidos, quer dizer que existem mais moradores de rua nos espaços públicos nesses bairros. As contagens assinalam o baixo índice de uso dos equipamentos assistenciais nesses bairros, essa baixa frequência de uso também pode indicar a ausência de um equipamento que atraia os moradores de rua o suficiente para frequentar continuamente os espaços de assistência social do bairro. Embora o número de moradores de rua não acolhidos varie nesses bairros ao longo da década, ao comparar ambos os gráficos fica clara a predominância daqueles que preferem permanecer nas ruas e não frequentar os equipamentos desse setor. A diferença mais significativa entre os bairros República e Sé é a perda de indivíduos em situação de rua não acolhidos no bairro República, uma queda de mais de $50 \%$ da população de rua nesse bairro. A pouca frequência do uso do sistema assistencial da área também indica um possível deslocamento dos não acolhidos a outros bairros, isso a fim de obter algum apoio do sistema, procurando

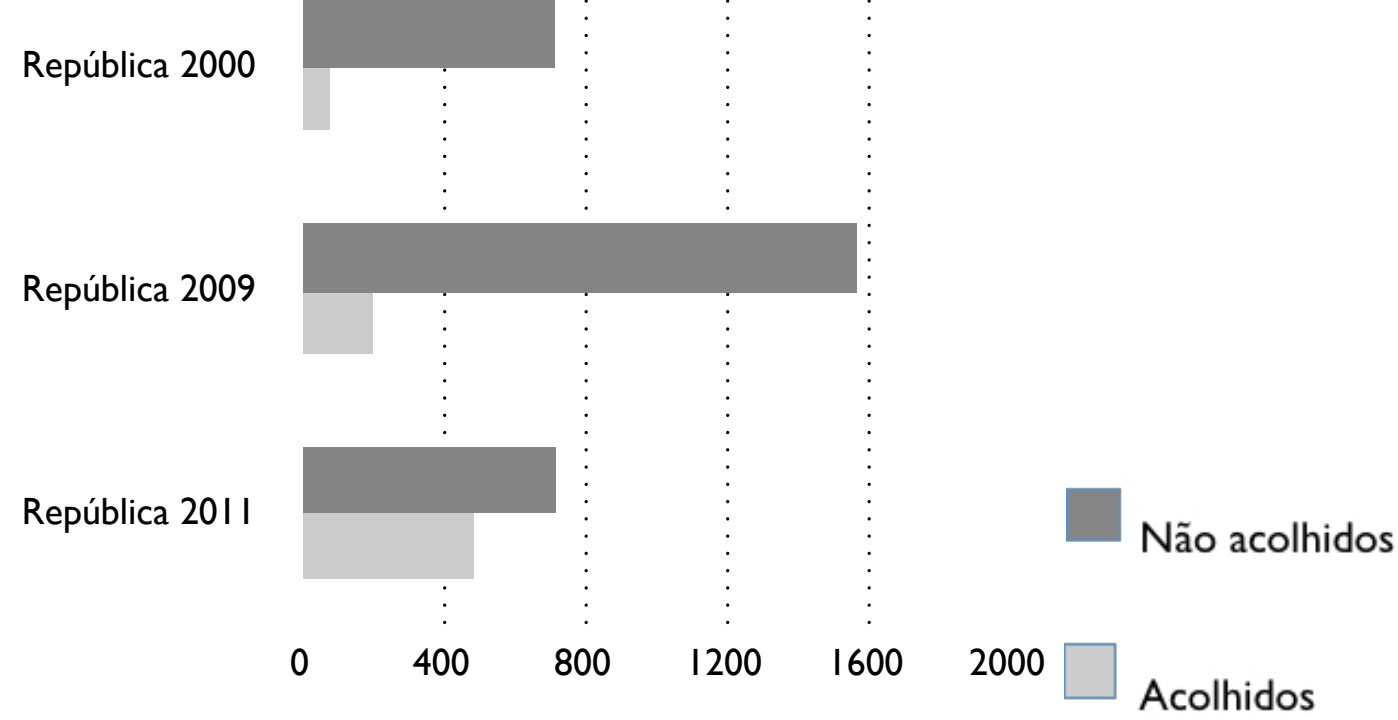

Gráfico 32 - Moradores de rua não acolhidos e acolhidos no Bairro República 2000 / 2009 / 2011 
algum tipo de serviço mais específico, diferente dos oferecidos nesses bairros. Observa-se que a forte atividade comercial da República, que atraíra anteriormente os não acolhidos, não constitui mais um fator para sua permanência no bairro no período de 2009 a 2011.

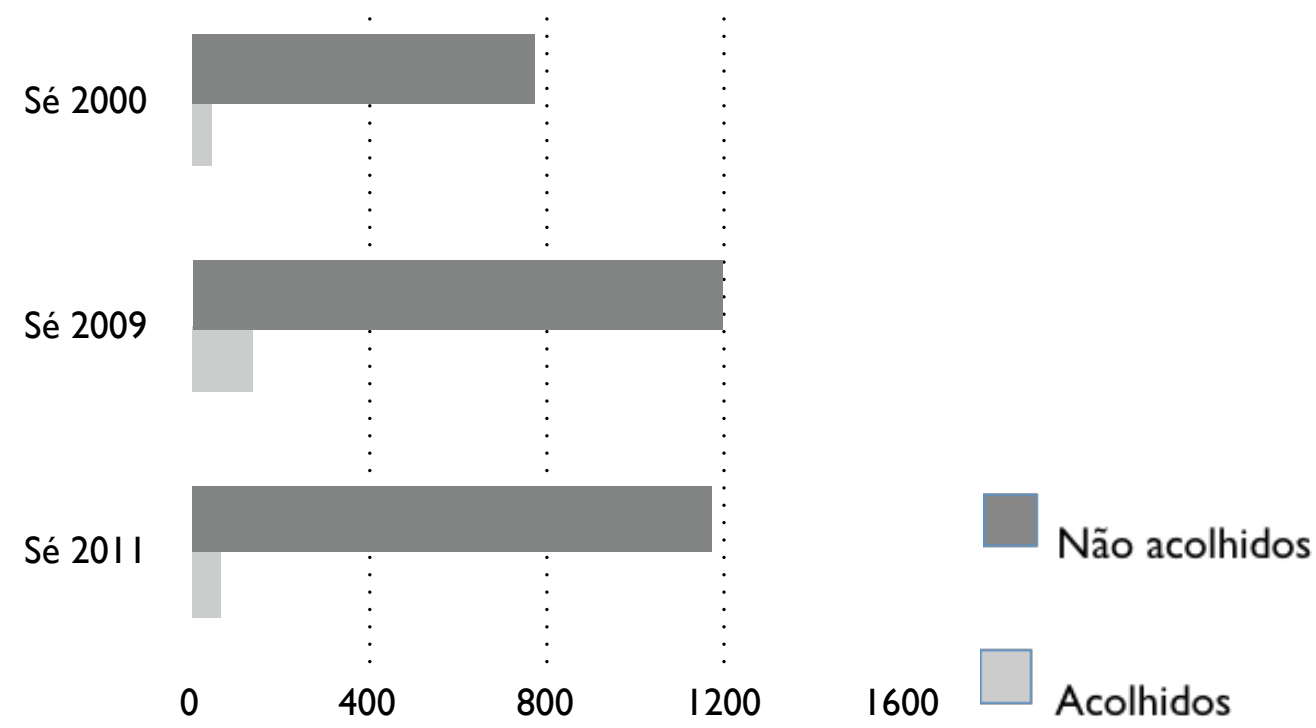

\section{Gráfico 33 - Moradores de rua não acolhidos e acolhidos no Bairro Sé $2000 / 2009 / 2011$}

Por outro lado, os bairros Bela Vista e Liberdade apresentam estabilidade quanto ao número de pessoas não acolhidas e uma variação no número dos acolhidos, sendo a tendência mais clara o crescimento das vagas nos centros de assistência social especializados para essa população nesses bairros. A diferença a notar nos dois bairros é a variação dos acolhidos no bairro Liberdade. Os acolhidos na Liberdade se reduzem de 2009 a 2012, com uma diferença de 237 acolhidos, o que representa uma queda de mais de 50\% da população acolhida no bairro. Essa quantidade considerável de vagas não aproveitadas nos 
indica uma possível expulsão ou retirada massiva da população de rua do bairro; essas vagas foram aproveitadas em 2012, já que, segundo o censo, um número quase similar de individuos procuraram acolher-se no equipamento dessa área de novo. Pode especular-se que embora esses (237) indivíduos pudessem ter deixado o bairro após 2009, uma quantidade similar volta para acolher-se no equipamento assistencial de Liberdade de novo em 2011.

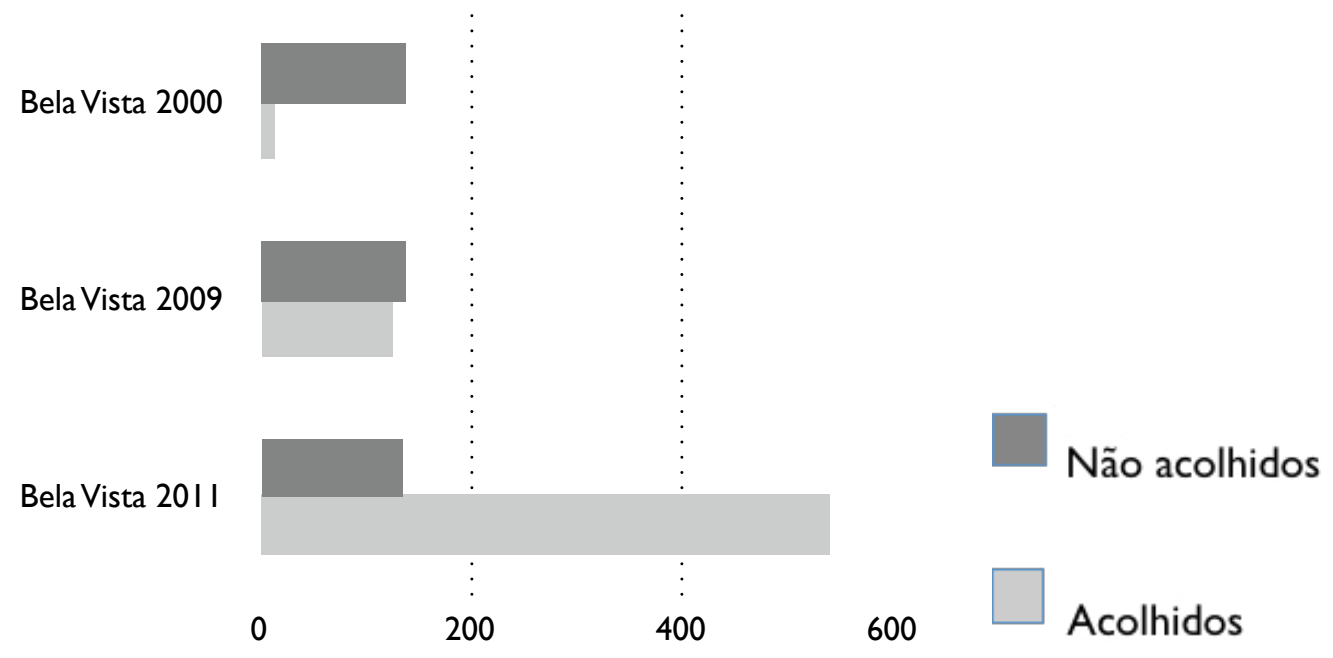

Gráfico 34 - Moradores de rua não acolhidos e acolhidos no Bairro Bela Vista 2000 / 2009 / 2011

A tendência do crescimento da população de rua acolhida continua nos outros dois bairros do centro da cidade, Bom Retiro e Santa Cecília, que apresentam um aumento da população de acolhidos no período entre 2000 e 2009. A diferença na dinâmica de ambos os bairros se apresenta de 2009 a 2012, já que no Bom Retiro se apresenta uma queda na população acolhida, enquanto em Santa Cecília aumenta a população dos acolhidos e dos não acolhidos. 


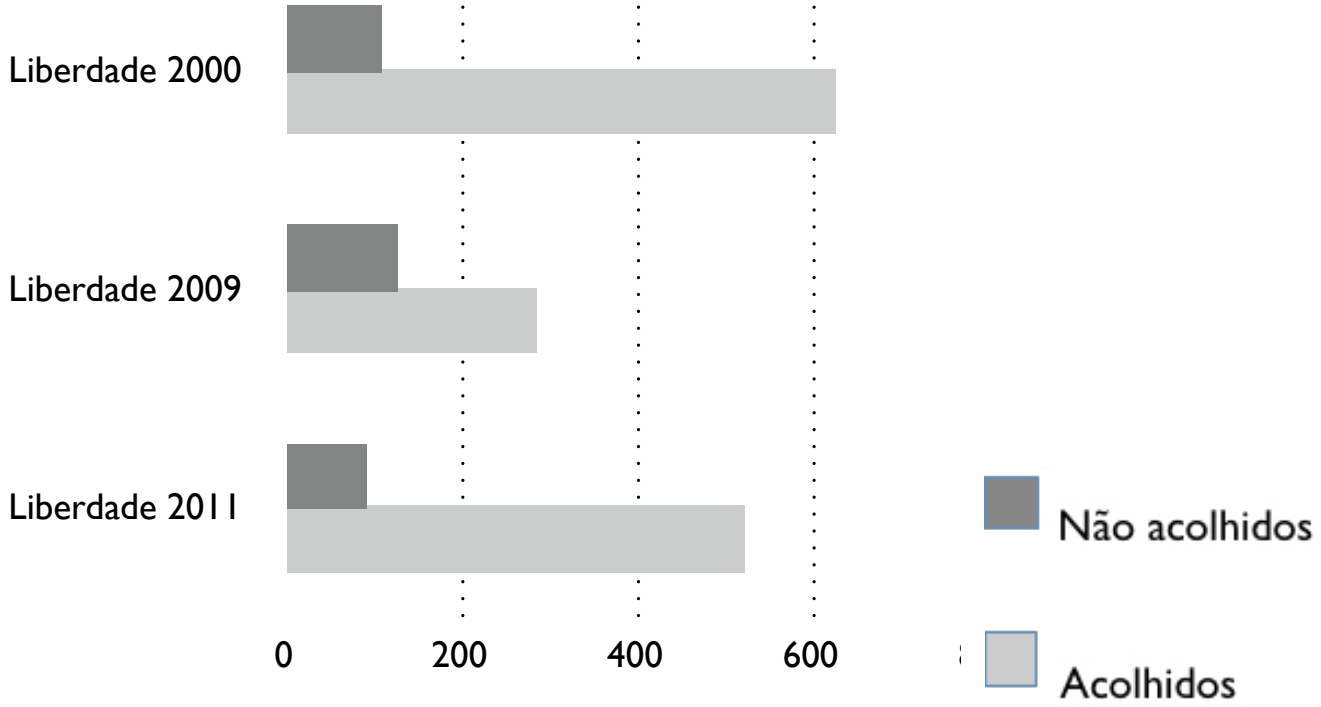

Gráfico 35 - Moradores de rua não acolhidos e acolhidos no Bairro Liberdade 2000 / 2009 / 2011

O último censo assinala que Santa Cecília se tornou o bairro da cidade que mais concentra moradores de rua, tanto acolhidos quanto não acolhidos. Esses dados indicam que existe una migração de outros bairros a Santa Cecília, tanto para procurar acolhimento nos equipamentos do bairro, quanto pelas nascentes áreas comerciais, pois elas apoiam as estratégias de subsistência do povo de rua.

Bom Retiro 2000

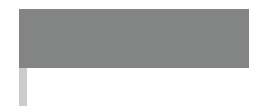

Bom Retiro 2009

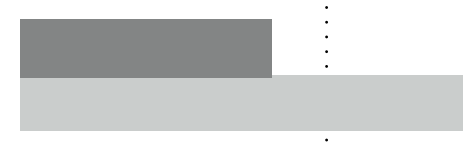

Bom Retiro 201 I

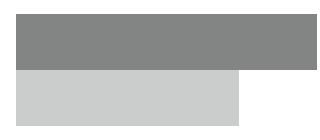

0

200

Não acolhidos

Acolhidos

Gráfico 36 - Moradores de rua não acolhidos e acolhidos no Bom Retiro 
Santa Cecília 2000

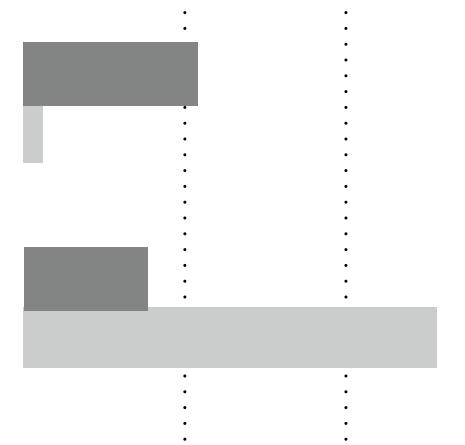

Santa Cecília 201 I

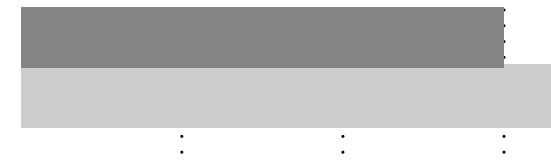

Não acolhidos

0

400

800

1200

1600

Acolhidos

\section{Gráfico 37 - Moradores de rua não acolhidos e acolhidos no Bairro Santa Cecília 2000 / 2009 / 2011}

A comparação dos dados dos três censos em cada bairro gera importantes resultados, pois conseguimos observar a crescente população de moradores de rua acolhidos nos equipamentos de assistência social da Prefeitura da cidade. Por outro lado, agrupando os dados dos censos, especificamente os dos acolhidos e não acolhidos, observamos uma variação mínima nos dados dos não acolhidos entre 2009 e 2011, em contraste com o crescimento súbito da população dos acolhidos no mesmo período. Esses números deixam claro que mais pessoas em situação de rua procuram os serviços de acolhimento na cidade. Esse crescimento dos moradores de rua acolhidos no centro concentra-se em três bairros, porém as novas vagas oferecidas pelo sistema assistencial aos moradores de rua distribuem-se entre Santa Cecília e Bela Vista. No casso do bairro Liberdade, o terceiro bairro que concentra moradores de rua acolhidos já oferecia espaços para os moradores de rua, o que quer dizer que essas vagas ocupadas em 2011 representam espaços já identificados no censo de 2000; a 
variação na população acolhida possivelmente está relacionada com a expulsão ou deslocamento por fatores externos dessa população. A proximidade de Santa Cecília com o setor denominado Cracolândia constitui outro fator que se relaciona com o crescimento da população acolhida. Essa proximidade implicaria o deslocamento curto dos moradores de rua da Cracolândia, que procuram acolhimento em algum equipamento no bairro de Santa Cecília.

\subsection{A RELAÇÃo POPULAÇÃo GERAL-POPULAÇÃo DE RUA}

Paralelo ao crescimento da população da cidade, nota-se que a partir de 2000 a população de rua da Subprefeitura Sé representava 0,91\% em relação ao total de moradores dessa área. Em 2009, essa relação era de 1,5\%. Em outras palavras, mesmo que a visibilidade do povo de rua não seja questionada, em números representam um grupo reduzido em comparação ao resto de moradores da área central. Os moradores da Subprefeitura Sé com condições de moradia formal apresentam dinâmicas diferentes daqueles que moram na informalidade. Em conjunto, o crescimento da população em geral é contínuo e devagar. Santa Cecília, Liberdade e Bela Vista apresentam mais concentração de população, enquanto Consolação e o Cambuci apresentam estabilidade na população nesse período.

Na Subprefeitura Sé em geral existe uma predominância de condições formais de moradia. Em números, a relação entre a população em geral (moradia formal) e a população de rua (moradia informal) não parece significativa. 


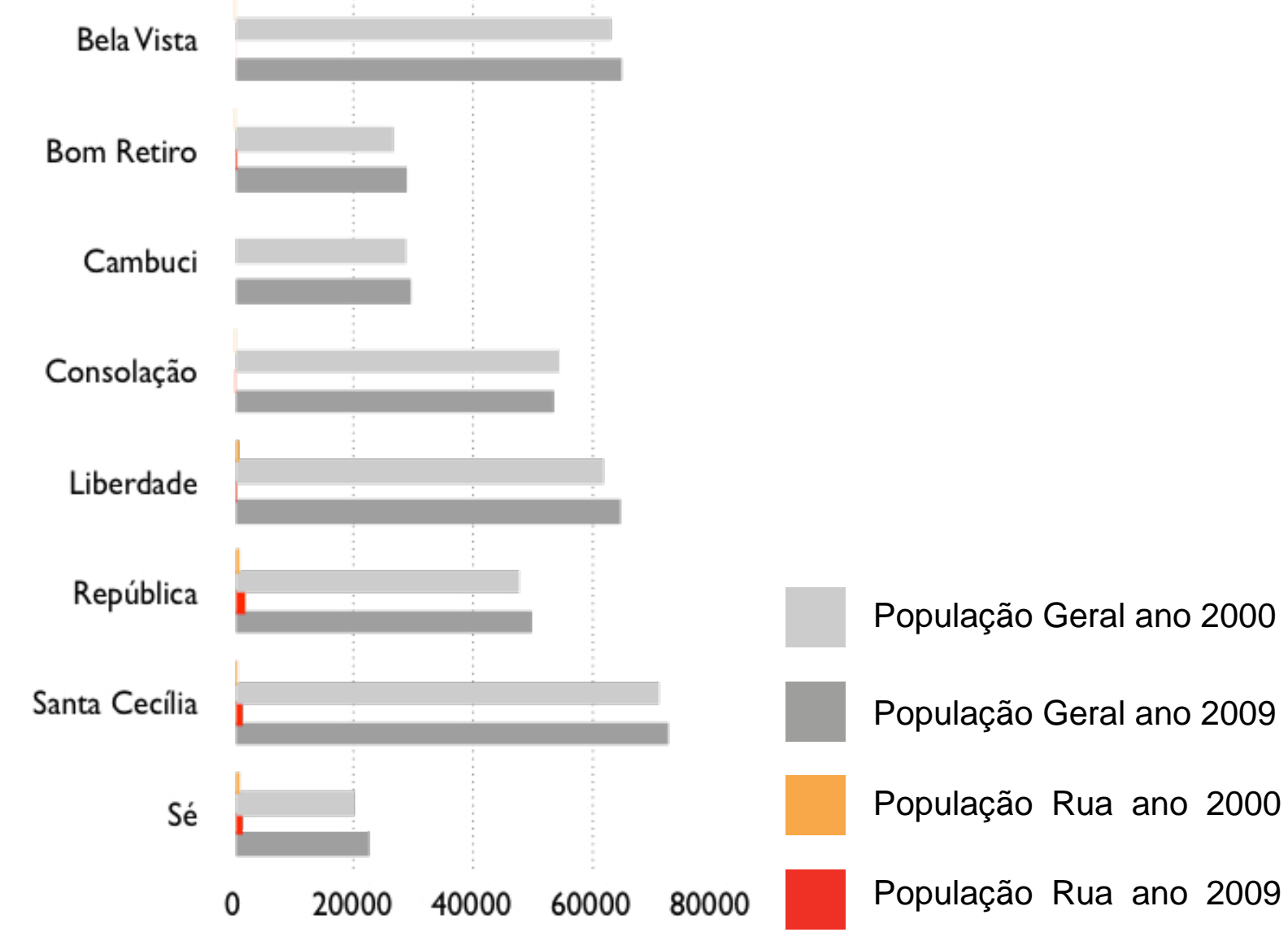

Gráfico 38 - Relação da população geral - população de rua 2000 / 2009

Em conjunto, o crescimento da população em geral é contínuo e devagar. Santa Cecília, Liberdade e Bela Vista apresentam mais concentração de população, enquanto Consolação e o Cambuci apresentam estabilidade na população nesse período. Na Subprefeitura Sé em geral existe uma predominância de condições formais de moradia. Em números, a relação entre a população em geral (moradia formal) e a população de rua (moradia informal) não parece significativa.

Mesmo que os números pareçam minimizar o problema, o fenômeno da moradia na rua é evidente nessa área, o que faz com que a Área Central seja estigmatizada com o adjetivo de "degradada". 
O exame da relação dos moradores formais e informais indica que a população moradora nas áreas atendidas pela Subprefeitura Sé apresenta sérios contrastes. Assim como existem bairros com numerosa população de rua (Santa Cecília, Sé e República), há bairros como Consolação e Bela Vista, que apresentam pontuação positiva nos índices de população com boas condições de vida no Mapa da Exclusão e Inclusão Social. Nesse mapa se assinala que "a maior incidência de exclusão ocorre nos distritos Sé $(-0,32)$ e República $(-0,28)$ ", bairros que possuem a maior quantidade de moradores de rua não acolhidos na cidade e que "foram priorizados no Programa Ação Centro - PMSP/BID, com ações que envolvem a reabilitação de espaços públicos e privados" (SEMPLA, 2004, p. 11). 

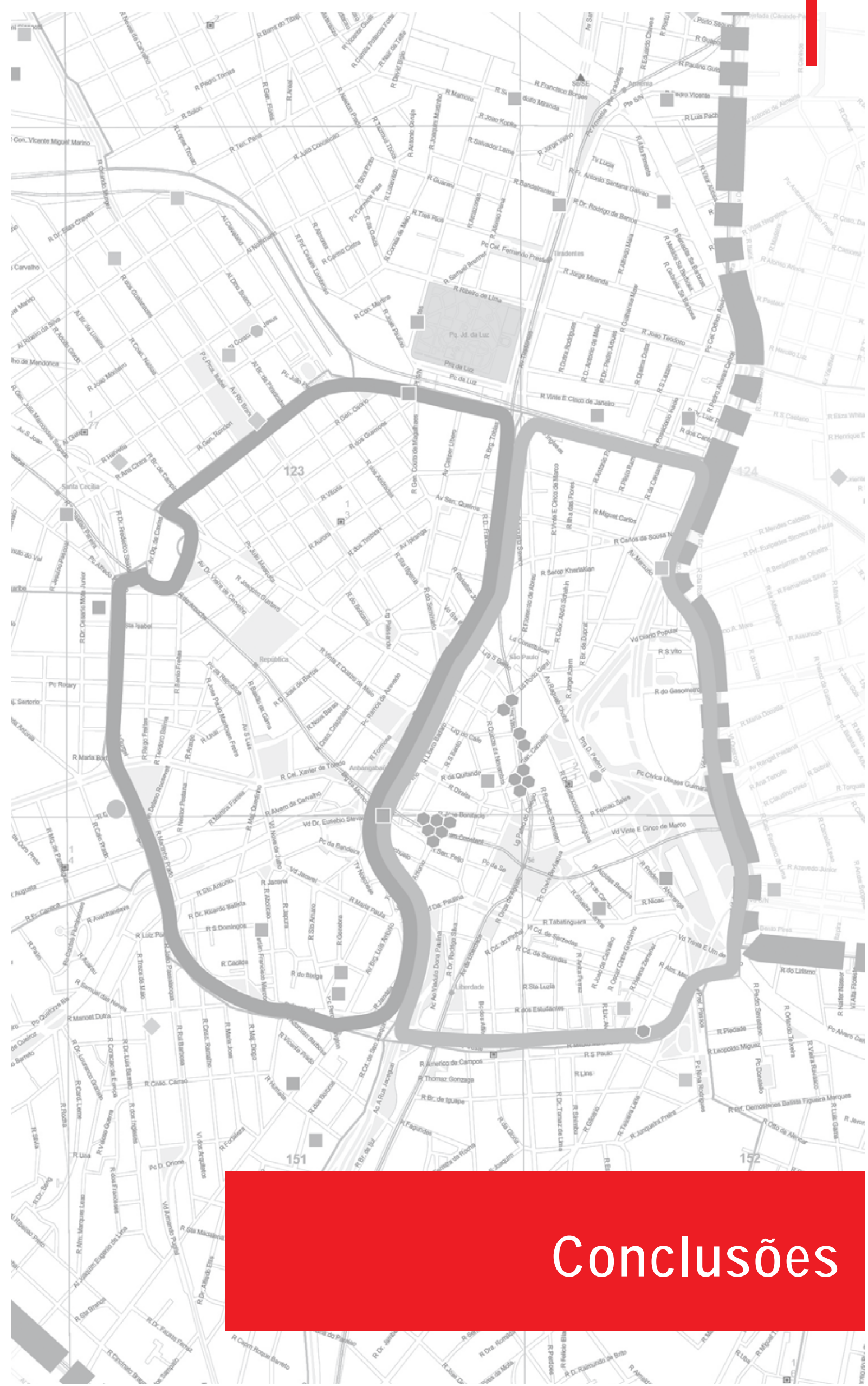


\section{CONCLUSÕES}

Toda pesquisa acadêmica começa com uma pergunta, essa pergunta inicial traz consigo muitas outras. O pesquisador utiliza cada uma delas para se orientar no caminho e completar dessa maneira um acervo de respostas e, uma vez respondidos esses questionamentos iniciais, passamos a procurar outros que nos levem a mais exercícios intelectuais, seja dentro ou fora do âmbito acadêmico. O pesquisador nato se questiona constantemente e nunca deixa de pesquisar.

Qualquer um poderia ter afirmado que pesquisar um fenômeno tão complexo como os deslocamentos territoriais dos adultos em situação de rua poderia ser mais difícil tratando-se de um pesquisador estrangeiro, porém a meu ver essa afirmação não poderia ter sido mais errada. Toda pesquisa exige do acadêmico a habilidade de também de dar uns passos atrás, a fim de enxergar a complexidade do fenômeno pesquisado como um todo, e essa postura pode às vezes facilitar para nós, os de fora. Afirmo que a condição de ser um pesquisador estrangeiro não foi um obstáculo para desenvolver o presente trabalho acadêmico, se não, mais uma vantagem, ampla e útil, usada ao longo desses meses para conhecer de uma maneira objetiva o fenômeno que decidi pesquisar na cidade de São Paulo. Às vezes foi uma vantagem silenciosa, pois os paulistanos, com os que conversei, esforçaram-se para explicar com detalhe os pormenores do fenômeno de rua na cidade, mesmo eu tendo estudado intensamente o assunto, e esse gesto de amabilidade foi bem-vindo e aproveitado.

A presente pesquisa teve inicio na cidade da Guatemala, quando eu trabalhei como 
parte da equipe municipal que implementou a modernização da atividade dos camelôs, localizados até 2010 na Sexta Avenida no Centro dessa cidade. Uma perspectiva particular permitiu enxergar nesse momento as consequências da modernização do comércio popular na área central e o seu impacto nos outros atores do centro da cidade: os adultos em situação de rua. Foi notório o relacionamento entre os camelôs e os adultos em situação de rua, pois muitas das atividades que geravam renda para esses últimos se relacionavam com o comércio popular, seja carregando pacotes ou catando o lixo no final do dia. Nesse contexto uns dependiam dos outros, o que formou uma rede de informalidade no centro da cidade. Essa frágil estrutura mudou após o projeto de revitalização.

Os estudos de Pós-graduação da Faculdade de Arquitetura e Urbanismo, da Universidade de São Paulo, deram a oportunidade de responder a pergunta "aonde eles vão?" Pois foi óbvio que o projeto de revitalização urbano no centro da cidade da Guatemala tinha causado uma mobilização dos adultos em situação de rua, fato que ficou como uma interrogação que no momento não foi respondida, por causa do início dos meus estudos no Brasil em 2011, quando deixei de trabalhar no setor público para refletir nos projetos desenvolvidos até então.

Foi uma escolha corajosa porém gratificante. Para pesquisar sobre os deslocamentos dos moradores de rua necessitei de esforço e de foco. Abriu-se a oportunidade de conhecer a fundo o fenômeno de rua, o centro da cidade de São Paulo e as valiosas ações do pessoal dos setores tanto público como privado que trabalham na reabilitação dos indivíduos nessa situação. A escolha foi sustentada pela ampla bibliografia 
sobre esse contexto, pois muitos pesquisadores focaram-se nos distintos aspectos da vida nas ruas das cidades brasileiras.

Destacam-se as pesquisas realizadas pelas professoras da Faculdade da Arquitetura e do Urbanismo da Universidade de São Paulo, Dras. Maria Cecília Loschiavo e Suzana Pasternak, ambas estudaram os materiais, espaços e objetos relacionados ao habitat dos moradores de rua, identificando a condição deles como entes criativos que interagem com a cidade de uma forma particular. Esses estudos foram valiosas fontes de conhecimento das condições de vida nas ruas das cidades brasileiras, o que adiantou muito o trabalho de campo, porque previu à saída às ruas, pois já se contava com uma ideia clara de como esses indivíduos moravam no espaço público. O resto da informação foi obtida mediante visitas de campo realizadas com o pessoal do Centro Integrado de Estudos e Programas de Desenvolvimento Sustentável de São Paulo (CIEDS), eles monitoram os espaços públicos dos bairros Sé e República, território que coincidiu com o recorte territorial da presente pesquisa. Partindo dessas informações, ficou claro que os estudos até então desenvolvidos tiveram um foco arquitetônico e não urbano, por isso a presente pesquisa abrangeu um sentido mais amplo.

A pesquisa do fenômeno de rua contribuiu para romper gradativamente os preconceitos. Os esforços das contagens contínuas, que começaram em 1991, permitiram identificar a população adulta como a maioritária nas ruas da cidade, por isso o presente trabalho se focou nessa faixa etária. Nesse grupo etário, existem três perfis de moradores de rua: o viciado, o desempregado e o liberado. Essa informação permitiu entender que não existe 
um único fator determinante que leve os indivíduos a uma situação de rua, embora exista uma conjunção de fatores. Destruiu-se o mito do morador de rua que está nessa condição pelo consumo de substâncias lícitas e ilícitas, pois as fontes assinalam que a população de rua adulta se distribui quase equitativamente nesses três perfis, não existe um único caminho à vida de rua rua ou uma razão absoluta que explique essa situação. São esses três perfis os que interagem na rua, pois nesse contexto os indivíduos tendem a gravitar com grupos, seja por reações estratégicas, ou por afinidade pessoal. Agrupar-se parece ser uma tendência que se mantêm entre os moradores de rua.

Processar as múltiplas pesquisas permitiu entender que os moradores de rua podem encontrar-se em uma das duas condições: temporária ou crônica. Essa informação ajudou a compreender as motivações dos deslocamentos, pois cada uma determina o agir dos moradores de rua, porém contribui às escolhas pessoais os motivam a se mobilizar na cidade. Essas extensas leituras adicionadas às visitas guiadas pelo pessoal do CIEDS, ajudaram-me a conhecer o agir dos moradores de rua. A pesquisa inicial deixou claro o contexto atual dos moradores de rua na cidade, eles constituem uma população reduzida, embora com uma notória visibilidade, principalmente na área central da cidade. A grande maioria de moradores de rua na cidade de São Paulo é do sexo masculino, solteiros, com empregos irregulares, o que quer dizer que em parte entram e saem da vida de rua devido ao desemprego prolongado.

As perguntas iniciais exigiram o desenvolvimento de uma análise urbana, pensando numa escala de território maior, fora dos espaços de ações individuais tradicionalmente 
abordados nas pesquisas da população em situação de rua. O comportamento individual já foi o foco dos acadêmicos. Essa orientação fez com que na presente pesquisa os deslocamentos fossem analisados como ações grupais e não isoladas ou alienadas de cada indivíduo em situação de rua. Nas últimas pesquisas se detectou o uso dos centros de assistência social como parte das estratégias de sobrevivência de alguns indivíduos em situação de rua, mesmo que expressem certo grau de desagrado pelas normas exigidas, esse dado foi levando em conta na analise dos deslocamentos. Devido a esse sentimento, procuram hotéis ou pensões sempre que conseguem renda suficiente, o que faz com que o centro da cidade seja um polo de atração, já que possui tanto os centros de assistência social, quanto as pensões com preços baixos.

A pesquisa bibliográfica apontou o caráter flutuante da população em situação de rua, o qual se relaciona com sua mobilidade, um rasgo inerente da vida de rua. Essa característica dificulta até hoje as contagens e faz com que não tenham exatidão, por isso a presente pesquisa as utilizou como uma referencia, a fim de conhecer a forma como os adultos em situação de rua ocupam o território. A mobilidade contínua da população de rua atinge não só a sua localização geográfica, pois eles se deslocam física, emocional, econômica e socialmente. Foi a partir desses dados que surgiu a uma importante reflexão: mesmo se deslocando em diferentes contextos, os moradores de rua permanecem na mesma situação, com raras exceções, a saída dessa circunstância é dificultosa e prolongada.

Existe uma relação direita entre o indivíduo em situação de rua e o território que 
ocupa, o espaço público constitui o palco de todas suas ações, aquelas que foram privadas somem, todo o seu agir é público, pois por morar na rua, sua cotidianidade mudou. A pesquisa apontou o grande apego dele aos espaços públicos e dinâmicas da cidade, especificamente as da área central. Para alguns dos indivíduos em situação de rua sua área de ação é ampla, parecem abraçar a ideia de que por agir no espaço público são donos dele, pensam que a vida na rua foi um ganho e acham que a condição de moradia formal é limitante porém monótona. Conhecem os espaços públicos desde uma outra perspectiva, essa ótica particular lhes permite transformar e apropriar-se de todo objeto com que interagem temporalmente. Essa apropriação é reconhecida pelo resto da população, que mesmo sem consenso, uma vez que no imaginário coletivo se aponta a relação da área central com a condição de rua.

Ao refletir na ação dos deslocamentos da população de rua, precisou-se tomar em conta seu caráter voluntário, isso faz com que eles sejam uns neonômades das cidades. Por se manter em constante movimento devem de carregar seu suporte vital consigo o tempo todo, razão pela qual esses objetos constituem tesouros e eventualmente alguns optam por fabricar transportes próprios como carroças ou alguns carrinhos. As motivações dos deslocamentos variam, podem relacionar-se com o consumo de alguma substância lícita ou ilícita, o grupo ao que pertence, a estratégia de subsistência desenvolvida ou a assistência social que no momento se requeira. Deve de se mencionar que algumas ações de terceiros as vezes motivam os deslocamentos dos indivíduos em situação de rua, por isso se consideraram essas ações involuntárias como parte dos deslocamentos territoriais. 
Considerando a estreita relação entre o território ocupado e os indivíduos em situação de rua, optou-se por levar em conta na analise a informação das contagens da Prefeitura para entender a forma em que se desenvolvem os deslocamentos territoriais, isso também a fim de esclarecer suas relações com as ações de assistência social e revitalizações do centro da cidade. Examinou-se detidamente nas contagens as dinâmicas dos moradores de rua acolhidos e os não acolhidos. Por relacionar-se o acolhimento às instituições de assistência social, as cifras dos acolhidos apontam os distritos da cidade que albergam a maior quantidade de moradores de rua e que, por tanto, constituem territórios frequentados por essa população. Ao comparar as contagens de cada bairro na analise, surgiu o caráter flutuante da população em situação de rua e o seu impacto na população da área central, por isso, examinaramse de ano a ano em cada um dos bairros do centro da cidade.

Embora o total de moradores de rua na Subprefeitura Sé tenha aumentado segundo o último censo, de 4093 (2009) a 4319 (2011), o número de moradores de rua nos bairros da Sé e República diminuiu, 24 e 851 respetivamente, o que indica que esse último bairro perdeu quase $50 \%$ da sua população. A diminuição dos moradores nesses bairros (-875) e o aumento no total de moradores de rua na área central (+226) sugerem que alguns dos moradores que deixaram a Sé e a República se deslocaram a outros bairros dentro da Subprefeitura Sé. Isso aponta para a existência de deslocamentos curtos por parte de moradores de rua no centro da cidade de São Paulo.

O aumento nas vagas dos moradores de rua acolhidos nos bairros Bela Vista $(+415)$ e Santa Cecília (+295), junto ao aumento de vagas ocupadas nos centros assistenciais 
da Liberdade (+237), indicam que é possível que os moradores tenham se deslocado da Sé e da República para esses três bairros na procura de assistência social.

Portanto, existem deslocamentos curtos desenvolvidos na área central, motivados principalmente pela procura de assistência social na rede municipal da cidade. Podemos considerar os deslocamentos longos motivados pela mesma razão, já que segundo o censo 2011, mais moradores de rua de outras áreas da cidade se deslocam para a área central à procura de acolhimento. Segundo pesquisa "os resultados do Censo 2011 reforçam a importância da região central na atração de pessoas em situação de rua" (PMSP, 2011, 11).

Estabeleceu-se o papel da assistência social como polo de atração de moradores de rua ao centro da cidade. As pesquisas impulsionadas pelo poder local permitiram identificar a natureza heterogênea da população de rua, razão pela qual se desenvolveu uma rede diversificada de assistência social, especializada no atendimento a essa população. Segundo a análise do censo de 2011, nessa linha o bairro de Santa Cecília se destaca pelo aumento do número dos moradores de rua acolhidos e não acolhidos.

O papel da renovação urbana nos deslocamentos territoriais curtos e longos dos adultos em situação de rua na cidade ainda não foi esclarecido pela analise desenvolvida na presente pesquisa, que foi baseada nos dados dos censos e na pesquisa bibliográfica nas fontes primárias e secundárias. Não existem dados que assinalem uma ligação direta entre os projetos revitalização urbana e a fuga dos moradores de rua no centro 
da cidade. Os dados obtidos foram insuficientes para determinar se a renovação urbana provoca os deslocamentos territoriais, curtos ou longos, desenvolvidos pelos adultos em situação de rua no período pesquisado. Precisa-se estudar a fundo as dinâmicas dos anos de 1998 e 2003 para esclarecer os fatores que afugentaram os moradores de rua dos bairros no centro da cidade. Os dados obtidos nos censos assinalam um decréscimo na população de rua do centro da cidade nesses anos, portanto uma analise comparativa das ações de renovação urbana e da assistência social nesses anos, pode esclarecer o seu relacionamento com os deslocamentos territoriais dos adultos em situação de rua. Se os anos 1998 e 2003 apresentaram decréscimos na população em situação de rua na cidade de São Paulo, uma análise específica pode esclarecer os fatores externos que tiveram influência no decrescimento dessa população.

As consequências da Operação Luz, iniciada em fevereiro de 2012, ainda não podem ser avaliadas para os fins da presente pesquisa. Seria necessário o estudo dos próximos censos (2013 e 2016) a fim de se estabelecer as consequências das ações do poder local em relação à população de rua expulsa e à que permaneceu na região acolhida pelo sistema assistencial. Examinar as próximas contagens permitirá estabelecer o impacto da ação, pois ser for bem sucedida, mudará as dinâmicas de vida dos adultos em situação de rua que ocupavam essa região da cidade, em caso contrário, a população voltará a frequentar a região da Luz. Essa última alternativa reafirmará uma das hipóteses da presente pesquisa, já que assinalou-se que as ações de terceiros afugentam os moradores de rua provocando deslocamentos curtos e involuntários. 

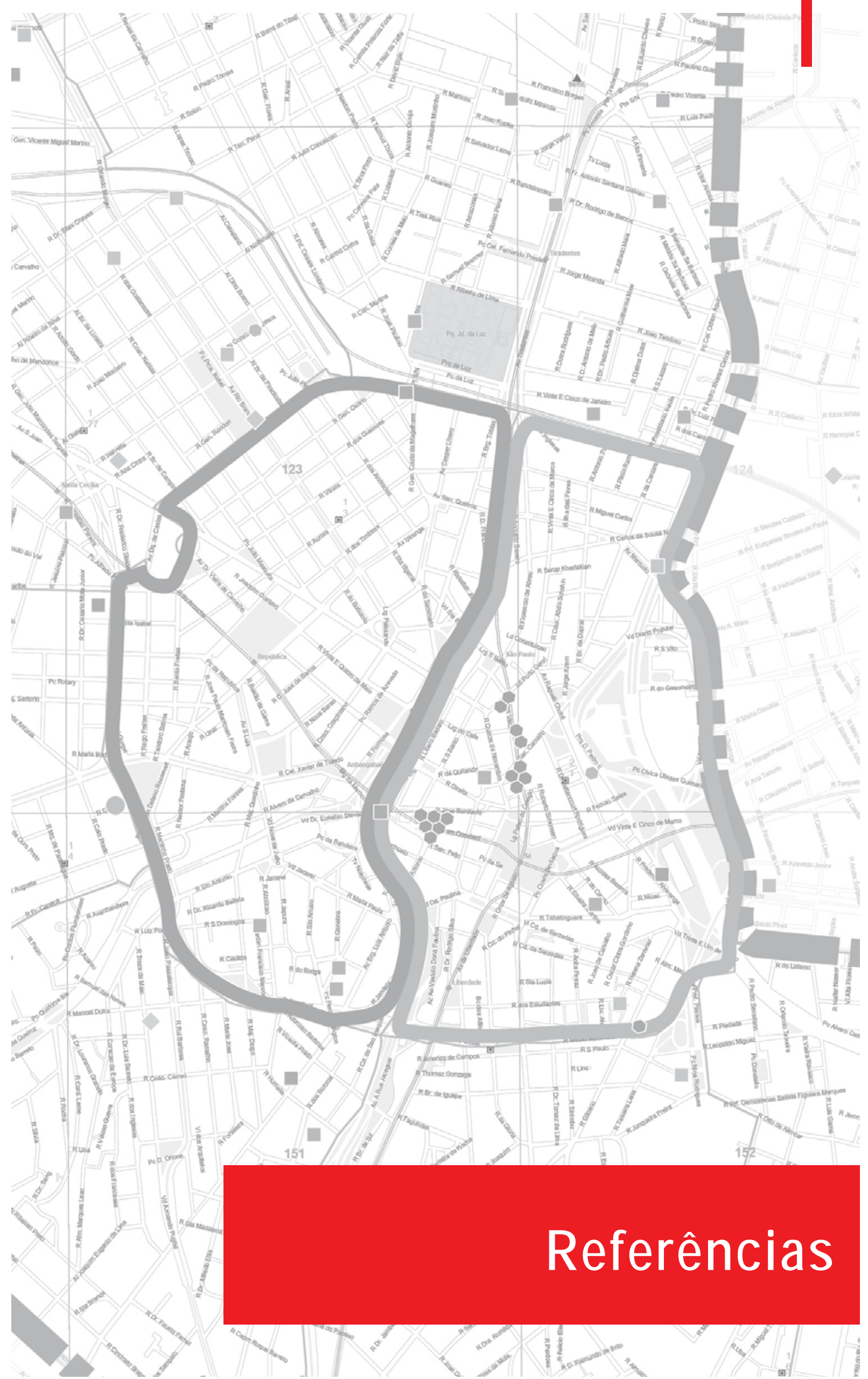


\section{REFERENCIAS}

ALVAREZ, A. M. D. S. A resiliência e o morar na rua: história de vida de moradores de rua - criança e adultos - da cidade de São Paulo. In: APSP, A. P. D. S. P.-. VI Congresso Paulista de Saúde Pública: Saúde na Cidade, 1999, São Paulo. APSP. p.36.

ANJOS DA NOITE Disponível em: <http://anjosdanoite.org.br/2012/index. php?artigo=55> Acesso em: Dic. 2011.

. O encontro transformador em moradores de rua na cidade de São Paulo. Psicologia \& Sociedade, v. 16, n. 3, p. 10, 2004a. Disponível em: < http://www.scielo. $\mathrm{br} / \mathrm{pdf} / \mathrm{psoc} / \mathrm{v} 16 \mathrm{n} 3>$.

. Um problema de toda a sociedade : os crimes cometidos contra moradores de rua chamam a atenção para a dura realidade enfrentada por mais de 10 mil pessoas em São Paulo. Jornal da Usp, p. 1, 2004b.

. Historias de vida de moradores de rua, situações de exclusão social e encontros transformadores. Saúde e Sociedade, v. 18, n. 2, p. 259-272, 2009. Disponível em: < http://www.scielo.br/pdf/sausoc/v18n2/09.pdf >.

ANTUNIASSI, M. H. R.; REZENDE, O. M. Trajetória de vida da população atendida nos serviços de acolhimento para adultos em situação de rua. 1. São Paulo: Universidade de São Paulo, 9.

APLICADA, I. D. P. E. O mapa da fome II : informações sobre a indigencia por municipios da federação. Mapa da fome. São Paulo 1993a.

. O mapa da fome III : indicadores sobre a indigencia no Brasil (classificação absoluta e relativa por municipios). Indicadores sobre a indigencia no Brasil. PELIANO, A. M. T. M. Rio de Janeiro 1993b.

ASSOCIAÇÃO VIVA O CENTRO. Destaque: Crimes contra moradores de rua, Viva o. Informe Viva o Centro, n. 213, p. 1, Setembro 2004 2004a. Disponível em: < http:// www.vivaocentro.com. br $>$. 
ASSESORIA TÉCNICA DE FUNDAP (Ed.). Discutindo a assistência social no Brasil. São Paulo: 1997.

BARROS, J. D. S. Moradores de rua - pobreza e trabalho : interrogações sobre a exceção e a experiência política brasileira. 2004. 117 Dissertation (Master). Sociology, University of São Paulo (Universidade de São Paulo) USP, São Paulo.

BLASI, G. And we are not seen. Ideological and Political Barriers to Understanding. American Behavioral Scientist, v. 37, n. 4, February 19941994.

BOLAÑOS, R. G. El diario del chavo del ocho. 5. México D. F.: Punto de Lectura, S. A. de C. V., 1995. 82 ISBN 970-731-094-4. Disponível em: < http://www.puntodelectura. com.mx >.

BOONEN, P. M. Sobre a vida em uma rua violenta : percepções de seus moradores. 2000. 126 Dissertation (MASTER). Philosphy and education, University of São Paulo (Universidade de São Paulo) - USP, São Paulo.

CALDEIRA, T. P. D. R. City of walls : crime, segregation, and citizenship in São Paulo. Berkeley: University of California Press, 2000. xvii, 487 p. ISBN 0520221427 (cloth alk. paper) 0520221435 (pbk. alk. paper). Disponível em: <http://www.loc.gov/ catdir/bios/ucal052/00028713.html >. Disponível em: <http://www.loc.gov/catdir/toc/ ucal041/00028713.html >. Disponível em: <http://www.loc.gov/catdir/description/ ucal042/00028713.html >.

. Cidade de muros. Crime, segregação e cidadania em São Paulo. 2rd. São Paulo: Editorial da Universidade de São Paulo, EDUSP / Editora 34, 2003. 400 ISBN 85-7326-188-9 (Ed. 34) / 85-314-0580-7 (Edusp).

CARRASCO, D. P. Moradores de rua e fatores de risco para a infecção pelo HIV, sífilis, HBV, HCV, na região central da cidade de São Paulo. In: BUCHALLA, C. M. B., VALQUÍRIA (Ed.). Inventário de Pesquisas e Estudos em DST e AIDS. São Paulo: Faculdade de Saúde Pública, 2003.

CASTILHO, H. D. A. L. Consensos e dissensos no Centro de São Paulo: significado, delimitação, apropriação e intervenção. 2008. 259 Phd (Phd). Architecture and Urbanism, University of São Paulo (Universidade de São Paulo) -USP-, São Paulo.

. Entrevista: Morar na rua, uma tragédia huamana. Informe Viva o Centro, n. 213, p. 1, Setembro 2004 2004b. Disponível em: < http://www.vivaocentro.org.br >. 
. Reportagem: Eleições 2004: Viva o Centro faz dez propostas aos candidatos. Informe Viva o Centro, n. 213, p. 2, $2004 c$.

CENTRO GASPAR GARCIA DE DIREITOS HUMANOS, 2012. Guarda Civil expulsa população em situação de rua no Largo de S.Francisco. Disponível em: <http://www. gaspargarcia.org.br/Videos.aspx?p=47> Acesso em: Jan. 2013.

. Acampamento relembra oito anos do massacre da Sé. Disponível em: <http:// www.gaspargarcia.org.br/Noticias.aspx?p=126> Acesso em: Jan. 2013.

COLECTA SOLIDARIA Disponível em: <http://www.coletasolidaria.gov.br/menu/ apresentacao> Acesso em: Dic. 2011.

CONSELHO MUNICIPAL DE PRESERVAÇÃO DO PATRIMÔNIO HISTÓRICO, CULTURAL E AMBIENTAL DA CIDADE DE SÃO PAULO - CONPRESP Disponível em: <http://www.prefeitura.sp.gov.br/cidade/secretarias/cultura/conpresp/> Acesso em: Nov. 2011.

CONDEIXA, D. Ação municipal com a população de rua e as casas de convivência em São Paulo. In: ROSA, C. M. M. (Ed.). População de Rua Brasil e Canadá. São Paulo: Editora de Humanismo, Ciência e Tecnologia HUCITEC Ltada., v.1, 1995. cap. 2, p.111-116. ISBN 85.271.0298-6.

COSTA, A. P. D. O olhar do respeito e da atenção na produção de um ensaio fotográfico. In: RODRIGUEZ, J. V. Q. D. C. M. (Ed.). Rua aprendendo a contar

Pesquisa nacional sobre a população em situação de rua. Brasilia: Ministério do Desenvolvimento Social e Combate à Fome, v.1, 2009. cap. 3, p.240. ISBN 978-8560700-34-9.

COORDENAÇÃO DE POPULAÇÃO E INDICADORES SOCIAIS, IBGE. Perfil dos municípios brasileiros : pesquisa de informações básicas municipais, 1999. Rio de Janeiro: IBGE, 2001. 121 p. ISBN 85240084908524008482 (CD-ROM).

Assistência Social. Primeira. Rio de Janeiro: Instituto Brasileiro de Geografía e Estatística - IBGE, 2009. 248 ISBN ISBN 978-85-240-4124-2. Disponível em: < http:// www.ibge.gov.br $>$.

D'INCAO, M. C. Comentários dos assesores sobre o perfil da população de rua. In: ROSA, C. M. M. (Ed.). População de Rua Brasil e Canadá. São Paulo: Editora de 
Humanismo, Ciência e Tecnologia HUCITEC Ltada., v.1, 1995. cap. 1, p.46-70. ISBN 85.271.0298-6.

DAMERGIAN, S. Reflexões sobre o trabalho - a resiliencia e o morar na rua : um estudo com moradores de rua, criancas e adultos na cidade de Sao Paulo, de Aparecida Magali de Souza Alvarez. 1999. University of São Paulo (Universidade de São Paulo) - USP, São Paulo. DEAR, M. Rethinking Los Angeles. London: Sage, 1996.

DEPARTAMENTO DO PATRIMÔNIO HISTÓRICO. Disponível em: <http://www. prefeitura.sp.gov.br/cidade/secretarias/cultura/patrimonio_historico/> Acesso em: Jun. 2011.

DERTÔNIO, H. R. O Bairro do Bom Retiro. Prefeitura Municipal, Secretaria de Educação e Cultura, Departamento de Cultura, 1971. 86 p.

DEPARTAMENTO DE ESTATÍSTICA E PRODUÇÃO DE INFORMAÇÃO, DIPRO. Subprefeituras da Sé e da Mooca. Mapa de Equipamentos Sociais. SEMPLA, S.

D. P. São Paulo: Prefeitura de São Paulo: Mapa de localização do equipamento de assistência social da cidade p. 2008.

. Olhar São Paulo - Contrastes Urbanos. São Paulo: Prefeitura de São Paulo, 2007. 64.

EMPRESA MUNICIPAL DE URBANIZAÇÃO, EMURB. Perímetro da área da operação. Operação Urbana Centro. PROCENTRO. São Paulo: Prefeitura de São Paulo 2001.

ENDRIGUE, T. D. C. Repensando o Projeto Boracea : proposta de abrigo para moradores de rua na cidade de Sao Paulo. 2002. Arquitecture and urbanism, University of São Paulo (Universidade de São Paulo) - USP, São Paulo.

FAGGIN LEITE, M. A. Um sistema de espaços livres para São Paulo. Revista Estudos Avançados, v. 25, n. 71, p. 159-174, 2001.

FERREIRA, M. A. B. O nobre e antigo Bairro da Sé. Prefeitura Municipal, Secretaria de Educação e Cultura, Departamento de Cultura, 1971. 158 p.

FILHO, J. J. B. As condições ambientias dos espaços habitados pelos moradores de rua da cidade de São Paulo. Cadernos Técnicos AUT, n. 11, p. 17, 2003.

FRÚGOLI JR, H. Centralidade em São Paulo : trajetórias, conflitos e negociações 
na metrópole. São Paulo, SP: Cortez Editora : Edusp : FAPESP, 2000. 254 p. ISBN 8524907444.

GLASSER, I.; ZYWIAK, W. Alcohol and drugs. Encyclopedia of Homelessness. LEVINSON, D. London: SAGE Publications, Thousand Oaks. 1: 7-13 p. 2004.

GEOGRAPH/MAPINFO / PUC - SP.-. Autonomia / Tabela 27 Classificação dos distritos1993/1994. In: SPOSATI, A. D. O. (Ed.). Mapa da exclusão/inclusão social da cidade de São Paulo. São Paulo: EDUC Editora da Pontíficia Universidade de São Paulo - PUC - SP -, v.1, 1996. cap. 1, p.126. ISBN 85-283-0093-5.

GUIMARÃES, L. S. D. B. M. Liberdade. São Paulo: Prefeitura do Município de São Paulo, Secretaria Municipal de Cultura , Departamento do Patrimônio Histórico, Divisão do Arquivo Histórico, 1979. 163 p.

HITARA, M. S. A crise da cidade e o espaço do morador de rua na região central da cidade de São Paulo. In: PLÁCIDO DA SILVA, J. e LOSCHIAVO DOS SANTOS, M. C. (Ed.). Estudios em Design das Universidades Estaduais UNESP e USP. São Paulo: Editoria UNESP, v.1, 2006. cap. 11, p.312. (Estudios em Design das Universidades Estaduais). ISBN 85-7139-707-4.

HOPPER, K.; BOUMOHL, J. Aeyance theory. Encyclopedia of Homelessness. LEVINSON, D. London: SAGE Publications, Thousand Oaks. 1: 1-3 p. 2004.

IN SEARCH OF THE AMERICA HOBO. Disponível em: <http://xroads.virginia. edu/ MA01/white/hobo/chapter2.html> Acesso em: Jun. 2011.

INSTITUTO BRASILEIRO DE GEOGRAFIA E ESTATÍSTICA IBGE. População Recenseada e Estimada, Município de São Paulo. 1950, 1960, 1980, 1991, 2000 a 2010: IBGE: 1 p. 2010.

. Perfil dos Municipios Brasileiros. 1. Rio de Janeiro: IBGE, 2003. 245 ISBN 85-240-3677-X.

ITAÚ, I. C.; BANCO DE DADOS INFORMATIZADO; PAULO, M. F. S. M. F. D. C. D. S. Praça da República. 2nd. São Paulo: Instituto Cultural Itaú, 1997.

ITAÚ, I. C.; BANCO DE DADOS INFORMATIZADO; PAULO., M. F. S. M. F. D. C. D. S. Praça da Sé. 2nd. São Paulo: Instituto Cultural Itaú, 1994. 
JACOBS, J. Morte e vida de grandes cidades. 2nd. São Paulo: Editora WMF Martins Fontes, 2009. 516 ISBN 978-85-7827-173-2. Disponível em: < http://www. wmfmartinsfontes.com. $\mathrm{br}>$.

JORGE, C. V. D. A. Consolação : uma reportagem histórica. São Paulo: Departamento do Patrimônio Histórico, Divisão do Arquivo Histórico, 1979. 202 p.

. Luz : notícias e reflexões. São Paulo: Departamento do Patrimônio Histórico, 1988. 127 p.

. Santa Ifigênia. São Paulo: Departamento do Patrimônio Histórico : Arquivo Histórico Municipal “Washington Luís”, 1999. 217 p.

. Santa Cecília. São Paulo: Departamento do Patrimônio Histórico, Arquivo Histórico Municipal “Washington Luís”, 2006. 139 p.

JUNIO, J. G. S. Moradores de rua. Revista Pólis, v. 1, n. No. 7, p. 56, 1992.

KOGA, D. A política de assistência social no Brasil. A assistência social como política de proteção social. In: ALBUQUERQUE, M. D. C. (Ed.). Participação popular em políticas públicas: espaço de construção da democracia brasileira. Paula Freire Santoro. São Paulo: Instituto Pólis, v.1, 2006. cap. 3, p.124.

LEVINSON, D. Causes. Encyclopedia of Homelessness. London: SAGE Publications, Thousand Oaks. 1: 434 p. 2004.

MANOEL, R. M. A questão do trabalho e não trabalho / São Paulo. In: ROSA, C. M. M. (Ed.). População de Rua Brasil e Canadá. São Paulo: Editora de Humanismo, Ciência e Tecnologia HUCITEC Ltada., v.1, 1995. cap. 4, p.166-167. ISBN 85.271.0298-6.

MARTINS, M. D. F. A. A caminho da rua : o encontro com as redes de assistência e a formação de lacos sociais entre moradores de rua em Belo Horizonte. 2001. 217 Tese (Doutorado). Geografia Humana, Universidade de São Paulo - USP, São Paulo.

MINISTÉRIO DO DESENVOLVIMENTO SOCIAL E COMBATE À FOME, MDS. Tipificação Nacional de Serviços Socioassistenciais. No. 109. SAÚDE, M. D.: Diário Oficial da União: 48 p. 2009.

. Disponível em: <http://www.mds.gov.br> Acesso em: Dic. 2012.

MOVIMENTO NACIONAL DA POPULAÇÃO DE RUA. MNPR. Conhecer para lutar. 
Instituto Pólis. FOME, M. D. D. S. E. C. À. São Paulo: Instituto Pólis. 1000: 23 p. 2010. MONTES, M. L. População de rua sua identidade e a questão da cidadania. In: ROSA, C. M. M. (Ed.). População de Rua Brasil e Canadá. São Paulo: Editora de Humanismo, Ciência e Tecnologia HUCITEC Ltada., v.1, 1995. cap. 5, p.191-199. ISBN 85.271.0298-6.

MORSE, R. Formação Histórica de São Paulo de comunidade à metrópole. São Paulo: 1922. 447.

MOURA, M. Moradores de rua - Vidas embrulhadas. Notícias FAPESP, n. 45, p. 32, 1999. Disponível em: < http://www.fapesp.br >.

NASTARI, M. Políticas Públicas de atenção à infância e adolescência no Brasil. In: ALBUQUERQUE, M. D. C. (Ed.). Participação popular em políticas públicas: espaço de construção da democracia brasileira. São Paulo: Instituto Pólis, v.1, 2006a. cap. 4, p.126.

. Políticas públicas de atenção à infância e adolescência no Brasil. Uma breve abordagem sobre origens, diagnóstico e perspectivas. In: ALBUQUERQUE, M. D. C. (Ed.). Participação popular em políticas públicas: espaço de construção da democracia brasileira. Paula Freire Santoro. São Paulo: Instituto Pólis, v.1, 2006b. cap. 4, p.124. PARK, R. E. Human communities; the city and human ecology. Glencoe, Ill.,: Free Press, 1952. $278 \mathrm{p}$.

PEREIRA, G. D. G. Sobre projetar e sobreviver na rua - um inventário de inventos. 2004a. Dissertação (Mestrado). Arquitetura e Urbanismo, Universidade de São Paulo - USP, São Paulo.

. Sobre projetar e sobreviver na rua - um inventário de inventos. 2004b. (Master). Architecture and urbanism, University of São Paulo (Universidade de São Paulo) -USP-, São Paulo.

PETER, H. Cidades do amanhã. 3rd. São Paulo: Editora Perspectiva S. A., 2009. 588 ISBN 978-85-273-0276-0. Disponível em: < http://www.editoraperspectiva.com.br >.

PONCIANO, L. Mil faces de São Paulo : pequeno dicionário histórico e amoroso dos bairros de São Paulo. Itapevi, SP: Editora Fênix, 2000. 143 p. ISBN 8574510572.

. Bairros paulistanos de A a Z. São Paulo, SP: Editora SENAC São Paulo, 
2001. 252 p. ISBN 8573592230.

. São Paulo : 450 bairros, 450 anos. São Paulo, SP: SENAC São Paulo Editora, 2004. 362 p. ISBN 8573593539.

PREFEITURA MUNICIPAL DE CAMPINAS, 2010. Disponível em: <http://www. campinas.sp.gov.br/noticias-integra.php?id=445> Acesso em: Jan. 2013.

PROGRAMA DE REABILITAÇÃO DA ÁREA CENTRAL. Disponível em: <http://www. procentro.com.br/site/Home.aspx> Acesso em: Jun. 2011.

INSTITUTO PÓLIS; NÚCLEO DE ESTUDOS E PESQUISAS EM SEGURIDADE E ASSISTÊNCIA SOCIAL NEPSAS/PUC-SP NEPSAS/PUC-SP. A política de assistência social na cidade de São Paulo. Segunda. São Paulo: Instituto Pólis, 2002. 112.

QUEIROGA, E. Os espaços livres e a esfera pública contemporánea no Brasil: por uma conceituação considerando propriedades (públicas e privadas) e a propriações. Sistema de espaços livres: o cotidiano, apropriações e ausências. Rio de Janeiro: FAU-UFRJ, p. 11, 20092009.

QUINTÃO, P. R. Centros de referência espaços de moradia transitória e reinserção para a população de rua na cidade de São Paulo. 2000. 78 Trabalho final de graduação (Graduação). Faculdade de Arquitetura e Urbanismo, Universidade de São Paulo USP, São Paulo.

RAUPP, L.; ADORNO, R. D. C. F. Uso de crack na cidade de São Paulo / Brasil. Toxicodependências, v. 16, n. 2, p. 22-37, 2010. ISSN 0874-4890. Disponível em:<http:// www.idt.pt/PT/RevistaToxicodependencias/Paginas/ArtigoDetalhe.aspx?ID=509 >.

REDE RUA. Disponível em: <http://www.rederua.org.br/index.php?option=com_cont ent\&task=view\&id=74\&ltemid=1> Acesso em: Nov. 2012.

ROCHA, P. A. M. D. O Patriarca dá as costas para a praça : trocada de lugar depois de reforma, a estátua de José Bonifácio se livra da visão de camelôs e moradores de rua. O Estado de São Paulo., n. Caderno Cidades/Metrópole, 2005.

SACCHETTO, J. Bixiga. Pingo nos is. 1st. São Paulo: Editorial Lemos, 2001.

SALVADOR, M. A. A questão da moradia e do alojamento / São Paulo. In: ROSA, C. M. M. (Ed.). População de Rua Brasil e Canadá. São Paulo: Editora de Humanismo, 
Ciência e Tecnologia HUCITEC Ltada., v.1, 1995. cap. 4, p.153-154. ISBN 85.271.02986.

SANTOS, A. L. T. D. Estudo da utilização da área central de São Paulo pelos moradores de rua como forma de aferição quantitativa e qualitativa dos espaços institucionais fornecidos aos mesmos. In: PLÁCIDO DA SILVA, J. L. D. S., MARIA CECILIA (Ed.). Estudios em Design das Universidades Estaduais UNESP e USP. São Paulo: Editora UNESP, v.1, 2006. cap. 14, p.312. (Estudos em design). ISBN 85-7139-707-4.

SANTOS, A. L. T. D.; SANTOS, M. C. L. D. Passagem e permanência nas ruas da cidade de São Paulo: Vivência dos moradores da Fábrica da Pompéia e os espaços institucionais. 2004. 421 Dissertação (Mestre). Faculdade de Arquitetura e Urbanismo / Estruturas ambientais urbanas, Universidade de São Paulo, São Paulo.

SANTOS, J. F. Q. Luz sobre nossa indigencia. Pequenas Empresas Grandes Negocios, v. 2, n. 15, Abril 19901990.

SANTOS, M. Espaço e sociedade : ensaios. Petrópolis Brazil: Editora Vozes, 1979. $152 \mathrm{p}$.

A natureza do espaço : técnica e tempo; razão e emoção. São Paulo: Editora Hucitec, 1996. 308 p.

SANTOS, M. et al. Território e sociedade : entrevista com Milton Santos. 1a. São Paulo, SP, Brasil: Editora Fundação Perseu Abramo, 2000. 127 p. ISBN 8586469262.

SANTOS, M. C. L. D. Design, homelessness and global cities. International Council of societies of Industrial Design ICSID, n. 4, p. 1, August 1998 1998. Disponível em: < http://www.icsid.org >.

. Cidades de plástico e papelão : o habitat informa dos moradores de rua em Sao Paulo, Los Angeles e Toquio. 2003. 145 Tese (Doutorado). Faculdade de Arquitetura e Urbanismo, Universidade de São Paulo, São Paulo.

Architecture, homelessness and the transformation of our societies. Human Layer, p. 1, Junho 2004 2004. Disponível em: < http://www.clab.fi >.

. Cities of Plastic and Cardboard - The Homeless Informal Habitat in São Paulo, Los Angeles and Tokyo. Housing and globalization. Kobe Japan: APNHR: 8 p. 2005. 
. Design, waste and homelessness. Design philosophy papers, n. 3, p. 7, 2005. ISSN 1448-7136.

. Living in the cities of plastic and cardboard: the homeless survival strategies and resistance in São Paulo, Los Angeles and Tokyo. Homelessness: a global perspective. SPEAK, S. Delhi. 1: 20 p. 2006.

. Living on the edge: from homelessness to recycling. Eco design 2006

Asia pacific symposium. Tokyo, Japan: 4 p. 2006.

- Notas sobre a dinâmica socioespacial da população em situação de rua: estratégias de adaptação, sobrevivência e o manejo dos recursos disponíveis no meio urbano. In: RODRIGUEZ, J. V. Q. D. C. M. (Ed.). Rua aprendendo a contar Pesquisa nacional sobre a população em situação de rua. Brasilia: Ministério do Desenvolvimento Social e Combate à Fome, v.1, 2009. cap. 6, p.240. ISBN 978-85-60700-34-9.

SANTOS, M. C. L. D.; PEREIRA, A. F. As várias vidas dos produtos, materiais e embalagens na cultura material da sociedade de consumo ao homeless. Anais P\&D Design '98 Congreso Brasileiro de Pesquisa e Desenvolvimento em Design, PUCRio,, v. 2, n. 1, p. 770, 25 a 28 de outubro 19981998.

SANTOS, M. C. L. D.; SIMON, A. Design education against exclusion: from Coopamare to Camapet. IV Global conference on sustainable product development and life cycle engineering. São Carlos, São Paulo: Editora Suprema. 1: 5 p. 2006.

SCHOR, S. M. Censo dos moradores de rua da cidade de São Paulo. Informações Fipe, n. 241, p. 3, 2000.

. Primeiro censo dos moradores de rua da cidade de São Paulo : procedimentos metodológicos e resultados. Economia Aplicada, v. 5, n. 4, p. 22, 2001.

. Metodologia do primeiro censo de moradores de rua da cidade de São Paulo.

Simposio Nacional de Probabilidade e Estatística. RINALDO, A. São paulo 2002.

SCHOR, S. M.; VIEIRA, M. A. D. C. Principais Resultados do Censo da População em Situação de Rua da Cidade de São Paulo. Primeira. São Paulo: Fundação Instituto de Pesquisas Econômicas FIPE, 2009. 15.

. Principais resultados do perfil socioeconômico da população de moradores 
de rua da área central da cidade de São Paulo, 2010. Primeira. São Paulo: Fundação Instituto de Pesquisas Econômicas, 2010. 23.

SECRETARIA DE AVALIAÇÃO E GESTÃO DA INFORMAÇÃO, MDS. I censo e pesquisa nacional sobre a população em situação de rua - síntese dos resultados. In: RODRIGUEZ, J. V. Q. D. C. M. (Ed.). Rua aprendendo a contar Pesquisa nacional sobre a população em situação de rua. Brasilia: Ministério do Desenvolvimento Social e Combate à Fome, v.1, 2009. cap. 4, p.240. ISBN 978-85-60700-34-9.

SECRETARIA DE DESENVOLVIMENTO URBANO DA PREFEITURA DE SÃO PAULO. Disponível em: <http://www.prefeitura.sp.gov.br/cidade/secretarias/ desenvolvimento_urbano/dados_estatisticos/> Acesso em: Ago. 2012.

SECRETARIA MUNICIPAL DE ASSISTÊNCIA SOCIAL E DESENVOLVIMENTO. Disponível em: <http://www.prefeitura.sp.gov.br/cidade/secretarias/assistencia_ social/> Acesso em: Ago.2012.

SECRETARIA MUNICIPAL DE PLANEJAMENTO, SEMPLA. Dinâmica Urbana. Municipio en Mapas. PAULO, P. D. S. São Paulo: Prefeitura de São Paulo: Série de mapas da cidade de São Paulo p. 2004a.

. Economía Urbana. Municipio en Mapas. PAULO, P. D. S. São Paulo: Prefeitura de São Paulo: Série de mapas da cidade de São Paulo p. 2004b.

. Indices Sociais. Municipio en Mapas. PAULO, P. D. S. São Paulo: Prefeitura de São Paulo: Série de mapas da cidade de São Paulo p. 2004c.

. Subprefeitura Sé. In: URBANO, S. M. D. P. (Ed.). Subprefeitura Sé. São Paulo: Secretaria Municipal de Planejamento Urbano, 2004.

. A implementação de Subprefeituras no Município de São Paulo. São Paulo: Prefeitura de São Paulo, 2001.

SERPA, A. O espaço púbico na cidade contemporânea. 1st. São Paulo: Editora contexto, 2009. 508 ISBN 978-85-7244-349-4.

SERRANO, C. E. G. Eu mendigo : alguns discursos da mendicância na cidade de São Paulo. 2004. 135 Dissertação (Mestrado). Faculdade de Psicologia, Universidade de São Paulo, São Paulo. 
SILVA, M. L. L. A condição do trabalho e o fenômeno população em situação de rua no Brasil - 1995 a 2005. In: KEMP, V. H. T. C., HELENA MARIA (Ed.). Catadores na Cena Urbana. Construção de políticas socioambientais. Belo Horizonte, Brasil: Autêntica Editora Lta, v.1, 2008.

SECRETARIA MUNICIPAL DE ASSISTÊNCIA E DESENVOLVIMENTO SOCIAL, SMADS. Plano de assistência social do município de São Paulo 2009-2012. Primeira. São Paulo: Prefeitura de São Paulo, 2010. 184.

SECRETARIA MUNICIPAL DE URBANISMO SMDU; DEPARTAMENTO DE ESTATÍSTICA E PRODUÇÃO DE INFORMAÇÃO DIPRO. Censo da População em Situação de Rua. Excel. RUA, C. D. P. E. S. D. São Paulo: Prefeitura de São Paulo 2010.

SILVEIRA, F. Enxergando o invisível: desafios metodológicos de uma (re) construção do olhar. In: RODRIGUEZ, J. V. Q. D. C. M. (Ed.). Rua aprendendo a contar Pesquisa nacional sobre a população em situação de rua. Brasilia: Ministério do Desenvolvimento Social e Combate à Fome, v.1, 2009. cap. 2, p.240. ISBN 978-85-60700-34-9.

SNOW, D.; ANDERSON, L. Desafortunados : um estudo sobre o povo da rua. Petrópolis: Vozes, 1998. 528 ISBN 8532620760.

OBSERVATÓRIO DE POLÍTICAS SOCIAIS. Índice paulista de vulnerabilidade social. SOCIAL, A. São Paulo: Prefeitura de São Paulo: Mapa em arquivo PDF p. 2004.

SPOSATI, A. Comentários / Formas de atuação com à população de rua. In: ROSA, C. M. M. (Ed.). População de Rua Brasil e Canadá. São Paulo: Editora de Humanismo, Ciência e Tecnologia HUCITEC Ltada., v.1, 1995. cap. 2, p.85-93. ISBN 85.271.02986.

SUBPREFEITURA SÉ. Disponível em: <http://www.prefeitura.sp.gov.br/cidade/ secretarias/subprefeituras/se/> Acesso em: Jun. 2011.

TACHNER, S. P.; RABINOVICH, E. P. Moradores de rua em São Paulo: Arranjos Espacias. In: (Ed.). Modos de morar na rua. São Paulo: Universidade de São Paulo USP / Fundação para a Pesquisa Ambiental FUPAM, 1998a. cap. 2, p.54. (Cadernos de pesquisa do LAP Série urbanização e urbanismo).

. Nômades urbanos. In: (Ed.). Modos de morar na rua. São Paulo: Universidade 
de São Paulo USP / Fundação para a Pesquisa Ambiental FUPAM, 1998b. cap. 1, p.54. (Cadernos de pesquisa do LAP Série urbanização e urbanismo).

VARANDA, W. Do direito a vida à vida como direito: sobrevivência, intervenções e saúde de adultos destituídos de moradia e trabalho nas ruas da cidade de São Paulo. 2003. 126 Dissertação (Mestrado). Faculdade de Saúde Pública, Universidade de São Paulo - USP, São Paulo.

- Liminaridade, bebidas alcoólicas e outras drogas : funções e significados entre moradores de rua. 2009. 198 These (Doutorado). Faculdade de Saúde Pública, Universidade de São Paulo, São Paulo.

VEIGA, L. D. et al. Trajetória de construção em situação de rua. In: RODRIGUEZ, J. V. Q. D. C. M. (Ed.). Rua aprendendo a contar Pesquisa nacional sobre a população em situação de rua. Brasilia: Ministério do Desenvolvimento Social e Combate à Fome, v.1, 2009. cap. 1, p.240. ISBN 978-85-60700-34-9.

VIEIRA, M. A. D. C. São Paulo / Perfil da População de Rua. In: ROSA, C. M. M. (Ed.). População de Rua Brasil e Canadá. São Paulo: Editora de Humanismo, Ciência e Tecnologia HUCITEC Ltada., v.1, 1995. cap. 2, p.42-45. ISBN 85.271.0298-6.

. (Ed.). Algumas formas de atendimento. In: População de rua. Quem é, como vive, como é vista. 2da. São Paulo: Editora Hucitec, v.1, 1992. cap. 3, p.113-148. ISBN 85-271.0211.0.

. (Ed.). Grupos operativos: uma possibilidade de trabalho. In: População de rua. Quem é, como vive, como é vista. 2da. São Paulo: Editora Hucitec, v.1, 1992. cap. 4, p.149-176. ISBN 85-271.0211.0.

- Pobreza, classe trabalhadora e população de rua. In: População de rua. Quem é, como vive, como é vista. 2da. São Paulo: Editora Hucitec, v.1, 1992. cap. 1, p.17-46. ISBN 85-271.0211.0.

. População de rua na cidade de São Paulo. In: População de rua. Quem é, como vive, como é vista. 2da. São Paulo: Editora Hucitec, v.1, 1992. cap. 2, p.47-112. ISBN 85-271.0211.0.

VIEIRA, V. F. Os donos do centro : discursos e estratégias de intervenção no centro de São Paulo. 2004. 104 Dissertação (Mestrado). Faculdade de Filosofia, Letras e 
Cièncias Humanas, Universidade de São Paulo, São Paulo.

WEBER, M. The city. Glencoe, III.,: Free Press, 1958. 242 p.

WOLCH, J.; DEVERTUEIL, G. New landscapes of urban poverty managment. In: MAY,

J. (Ed.). Time-Space. London: Routledge, 2001. p.149-168.

ZANETTI, V. Z. Planos e projetos ausentes: Desafíos e perspectivas da requalificação das Áreas Centrais de São Paulo. 2005. 356 Planos e projetos ausentes (Phd). Architecture and urbanism, University of São Paulo (Universidade of São Paulo) USP, São Paulo. 